\title{
The Biosynthesis of Artemisinin (Qinghaosu) and the Phytochemistry of Artemisia annua L. (Qinghao)
}

\author{
Geoffrey D. Brown
}

Department of Chemistry, The University of Reading, Whiteknights, Reading, RG6 6AD, UK; E-Mail: g.d.brown@reading.ac.uk

Received: 13 September 2010 / Accepted: 17 October 2010 / Published: 28 October 2010

\begin{abstract}
The Chinese medicinal plant Artemisia annua L. (Qinghao) is the only known source of the sesquiterpene artemisinin (Qinghaosu), which is used in the treatment of malaria. Artemisinin is a highly oxygenated sesquiterpene, containing a unique 1,2,4trioxane ring structure, which is responsible for the antimalarial activity of this natural product. The phytochemistry of $A$. annua is dominated by both sesquiterpenoids and flavonoids, as is the case for many other plants in the Asteraceae family. However, $A$. annua is distinguished from the other members of the family both by the very large number of natural products which have been characterised to date (almost six hundred in total, including around fifty amorphane and cadinane sesquiterpenes), and by the highly oxygenated nature of many of the terpenoidal secondary metabolites. In addition, this species also contains an unusually large number of terpene allylic hydroperoxides and endoperoxides. This observation forms the basis of a proposal that the biogenesis of many of the highly oxygenated terpene metabolites from A. annua - including artemisinin itself may proceed by spontaneous oxidation reactions of terpene precursors, which involve these highly reactive allyllic hydroperoxides as intermediates. Although several studies of the biosynthesis of artemisinin have been reported in the literature from the 1980s and early 1990s, the collective results from these studies were rather confusing because they implied that an unfeasibly large number of different sesquiterpenes could all function as direct precursors to artemisinin (and some of the experiments also appeared to contradict one another). As a result, the complete biosynthetic pathway to artemisinin could not be stated conclusively at the time. Fortunately, studies which have been published in the last decade are now providing a clearer picture of the biosynthetic pathways in A. annua. By synthesising some of the sesquiterpene natural products which have been proposed as biogenetic precursors to artemisinin in such a way that they incorporate a stable isotopic
\end{abstract}


label, and then feeding these precursors to intact $A$. annua plants, it has now been possible to demonstrate that dihydroartemisinic acid is a late-stage precursor to artemisinin and that the closely related secondary metabolite, artemisinic acid, is not (this approach differs from all the previous studies, which used radio-isotopically labelled precursors that were fed to a plant homogenate or a cell-free preparation). Quite remarkably, feeding experiments with labeled dihydroartemisinic acid and artemisinic acid have resulted in incorporation of label into roughly half of all the amorphane and cadinane sesquiterpenes which were already known from phytochemical studies of $A$. аnnua. These findings strongly support the hypothesis that many of the highly oxygenated sesquiterpenoids from this species arise by oxidation reactions involving allylic hydroperoxides, which seem to be such a defining feature of the chemistry of A. annua. In the particular case of artemisinin, these in vivo results are also supported by in vitro studies, demonstrating explicitly that the biosynthesis of artemisinin proceeds via the tertiary allylic hydroperoxide, which is derived from oxidation of dihydroartemisinic acid. There is some evidence that the autoxidation of dihydroartemisinic acid to this tertiary allylic hydroperoxide is a non-enzymatic process within the plant, requiring only the presence of light; and, furthermore, that the series of spontaneous rearrangement reactions which then convert this allylic hydroperoxide to the 1,2,4-trioxane ring of artemisinin are also non-enzymatic in nature.

Keywords: artemisinin; dihydroartemisinic acid; sesquiterpene; biosynthesis; Artemisia annua; phytochemistry; oxidation; allylic hydroperoxide

1. Introduction

1.1 Malaria

1.2 Artemisia annua (Qinghao)

1.3 Artemisinin (Qinghaosu)

2. The Phytochemistry of Artemisia annua L. (Qinghao)

2.1 Aliphatic hydrocarbons, alcohols, aldehydes and acids

2.2 Aromatic alcohols, ketones and acids

2.3 Phenylpropanoids

2.4 Flavonoids

2.5 Monoterpenoids

2.5.1 Regular acyclic monoterpenes

2.5.2 Irregular acyclic monoterpenes

2.5.3 Monocyclic monoterpenes

2.5.4 Bicyclic monoterpenes

2.6 Sesquiterpenoids

2.6.1Farnesane sesquiterpenes

2.6.2 Monocyclic sesquiterpenes

2.6.3 Bicyclic sesquiterpenes

2.6.4 Tricyclic sesquiterpenes

$2.7 \quad$ Higher terpenoids

2.7.1 Diterpenes

2.7.2 Triterpenes and sterols

2.8 Nitrogen-containing natural products 
3. The Biosynthesis of artemisinin (Qinghaosu)

3.1 Phase 1 (isopentenyl pyrophosphate to amorpha-4,11-diene)

3.2 Phase 2 (amorpha-4,11-diene to dihydroartemisinic acid)

3.3 Phase 3 (dihydroartemisinic acid to artemisinin)

4. Strategies for the production of artemisinin from A. annua and derived systems

4.1 Plant breeding programmes

4.2 Plant tissue culture

4.3 Endophytic fungi

4.4 Genetic engineering

5. Acknowledgements

6. References

\section{Introduction}

\subsection{Malaria}

Malaria is an infectious disease which has affected human beings since the dawn of recorded history. By the middle of the last century, however, many felt that malaria was on the retreat and that one day it might even be vanquished. Two factors were primarily responsible for this perceived reduction in the severity of the malarial threat. Firstly, the Anopheles mosquito, which transmits the disease to humans, could at last be controlled by widespread application of the insecticide DDT. Secondly, the Plasmodium parasite, which causes malaria (four members of the genus infect humans: $P$. falciparum, $P$. vivax, $P$. malariae and $P$. ovale), could also be effectively be controlled by the use of synthetic analogues of quinine (itself also a natural product, obtained from the bark of the cinchona tree), such as chloroquine, which had been developed before World War II.

By the 1960's, however, malaria was back with a vengeance. The mosquitoes were developing resistance to DDT, which was soon to be banned in any case because of environmental concerns. The Plasmodium falciparum parasite, which is responsible for cerebral malaria, an often fatal complication, was also developing resistance to chloroquine. Thailand and South America were the first regions to be affected, but resistance to chloroquine soon spread to many other parts of the World. Nowadays, it is particularly serious in South East Asia. It was against this background of increasing resistance, and of the on-going wars in neighboring Cambodia and Vietnam, that the Chinese government began a major initiative to discover new antimalarials from plants used in Traditional Chinese Medicine (TCM).

\subsection{Artemisia annua (Qinghao)}

The herb "Qinghao" first appeared in a book entitled "Wu Shi Er Bing Fang" (Prescriptions for Fifty-Two Ailments) more than two thousand years ago. The earliest reported use for Qinghao was for the treatment of haemorroids; but "Zhou Hou Bei Ji Fang" (Handbook of Prescriptions for Emergency Treatment), written in $340 \mathrm{AD}$, describes the use of Qinghao as a treatment for fevers [1]. The first text in which Qinghao might specifically be identified as a remedy for malaria is "Ben Cao Gang Mu" (1596) in which the herb is described as "a treatment for hot and cold due to intermittent fever illness". These old pharmacopeias describe preparations in which the leaves (collected in summer or spring) are 
pounded with a pestle and mortar in order to express the "juice". This procedure was, perhaps, intended to improve the recovery of essential oils from trichomes on the leaf surface, in which the active principal, artemisinin, is now thought be contained.

It is not entirely clear whether "Qinghao" which is referred to in these ancient texts is solely Artemisia annua L. [2]; and it has sometimes been suggested that the term may also have been used synonomously for Artemisia apiacea Hance [1]. In the modern pharmacopeia of the People's Republic of China, however, Qinghao is now officially listed as the aerial parts of A. annua L. [3] (5g dried herb/1L water is suggested for the preparation of a decoction). In the TCM system, A. annua is cool in nature (yin) and is therefore suitable for treating "heat" syndromes (yang), such as malaria; other applications described for this cooling herb, such as the relief of symptoms of febrile diseases, tidal fever, low grade fever and summer heat stroke, are also consistent with this classification.

\subsection{Artemisinin (Qinghaosu)}

As has been noted, after a brief respite lasting only a few decades, malaria was once again on the increase in the 1960s. In 1967, the Chinese government launched a program to discover new antimalarial drugs based on a systematic investigation of indigenous plants used in TCM.

When the Chinese scientists made infusions of $A$. annua with hot or boiling water, as described in the ancient texts, they observed no activity against mice infected with Plasmodium berghei (a rodent malarial parasite). However, thanks to the insight of Prof. Tu, cold ethereal extracts of $A$. annua were also tested and these did show encouraging activity, leading to the isolation of the active principle, artemisinin, in 1972 (the original reports of this new drug referred to "Qinghaosu", meaning "principle from Qinghao" [4]). Nowadays, artemisinin is extracted from A. annua using diethyl ether, hexane, petroleum ether or even petrol as solvent [5].

At first sight, the lack of effectiveness for hot water extracts from A. annua appears to be at variance with the reports in the traditional pharmacopeias (in addition, we now know that artemisinin is virtually insoluble in water). One possible explanation is that the original recipes normally required that A. annua preparations be made in conjunction with other herbs (so-called "minister" or "guide" herbs). For example, in the herbal "Wen Bing Tiao Bian" (1798), an infusion of A. annua together with Amyda sinensis, Rehmannia glutinosa, Anemarrhena asphodeloides and Paeonia suffructicosa is described. It is quite possible that saponins, or other components from the latter three herbs which are capable of acting as detergents, might be able to assist the dissolution of artemisinin in water ( $c$. the suggestion in Section 2.4 that flavonoids, which are present both in A. annua and other herbs, may be able to potentiate the antimalarial effect of artemisinin in crude plant preparations).

Clinical studies in the late 1970 s with patients infected with $P$. vivax or P. falciparum demonstrated that artemisinin could kill the malarial parasite very quickly at the schizont stage of the parasite's life cycle (i.e. while it infected the human red blood cell) and with no obvious side effects [6]. Most importantly, artemisinin was completely effective in the treatment of chloroquine-resistant Falciparum malaria [7]. The discovery of this new and potent antimalarial attracted the attention of the World Health Organization (WHO), which had the resources to develop artemisinin globally; and both $A$. annua and artemisinin soon became well known outside of China. However, the therapeutic value of artemisinin was limited by its low solubility in both oil and water, and this has lead to the development 
of semi-synthetic drugs with pharmacological properties superior to those of the parent [8]. The most important such derivatives are artemether, arteether and artesunate (Figure 1), which exhibit greater potency than artemisininin itself, as well as improved solubility, and favourable metabolic and hydrolytic stabilities. Formulations based on these drugs are now at the heart of the WHO's global fight against malaria The entire world production of such semi-synthetic artemisinin derivatives is currently reliant on harvesting and extraction of artemisinin from A. annua plants, which is practiced on a multi-tonne scale in countries such as China and Vietnam.

Figure 1. Artemisinin and its semi-synthetic derivatives, which are currently used in the treatment of malaria.

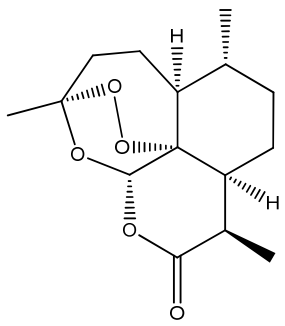

Artemisinin

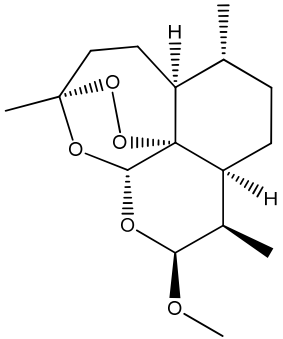

Artemether

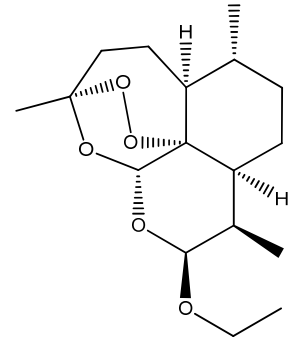

Arteether

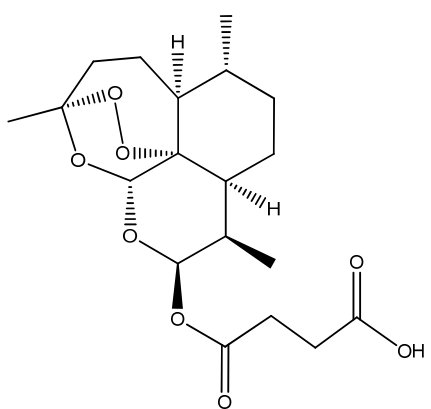

Artesunate

Malaria is now the most serious infectious disease in the World, with at least 300 million cases reported every year. It is estimated to be responsible for up to 2 million deaths annually - mainly amongst children - with more than half of the deaths occurring amongst the poorest $20 \%$ of the World's population. The importance of artemisinin has been founded on a continuing lack of resistance almost three decades after its introduction - although, very recently, reports of the emergence of resistance have indeed begun to appear [7,8] This slow onset of resistance may be a consequence of the unique mechanism of action for this drug, which is associated with the unusual endoperoxide group. It is thought that artemisinin becomes activated when its endoperoxide group comes into contact with $\mathrm{Fe}(\mathrm{II})$ in free haem groups, which have been liberated by the parasite's digestion of the haemoglobin contained in the red blood cell.

The appearance of resistance to artemisinin could be a devastating blow for many parts of South East Asia and Africa, where artemisinin-based drugs are currently the only effective treatment for malaria (resistance to the older generation of quinine-derived antimalarials having already become endemic to these regions). In an attempt to forestall the emergence of resistance, the WHO have been recommending that artemisnin should be taken in combination with another antimalarial drug - socalled Artemisinin Combination Therapy (ACT). This strategy is designed to slow the development of resistance, because during treatment with two drugs, the chance of a mutant emerging which is resistant to both is the product of the probabilities of resistance arising to either drug separately. It seems that, in the continuing absence of an effective malaria vaccine, the development of new antimalarial drugs - most likely derived from, or inspired by, artemisinin - will continue to be our primary weapon in the fight against malaria. 


\section{The Phytochemistry of Artemisia annua L. (Qinghao)}

Artemisia annua Linn. (sweet wormwood; Chinese wormwood) is a member of the Asteraceae family of plants (formerly Compositae). It is a native of China, originally found in the steppes of Chahar and Suiyuan Provinces, but is now widespread in many parts of the World, and is cultivated in countries such as Vietnam, Thailand, Burma, Madagascar, Malaysia, USA, Brazil, Australia (Tasmania), Holland, Switzerland, France and Finland. Most phytochemical investigations of A. annua have employed the aerial parts (leaves and/or stems - sometimes also including the flowers) although one report has concentrated on the seeds [9]. The phytochemistry of $A$. annua is dominated by terpenoids (in particular sesquiterpene lactones), flavonoids, coumarins and other shikimate metabolites, as is the case for many other members of the genus Artemisia. The sesquiterpene, artemisinin, is however unique to A. annua - it has been searched for on several occasions in other species in the genus Artemisia, always without success [10,11]. The artemisinin content from A. annua is highly variable, ranging anywhere between $0.01 \%$ and $1 \%$, depending on variety, and can even be as high as $1.4 \%$ in some cultivated strains.

There have been several reviews of the phytochemistry of A. annua [12-15]. In this section, an attempt has been made to provide a comprehensive review of the original phytochemical literature concerning A. annua up to 2009. Almost six hundred secondary metabolites are described, which have been divided into eight sections (Sections 2.1-2.8) and further sub-divided into more than forty Tables. The grouping of these natural products from A. annua is based on the (largely biogenetic) classification adopted by a standard reference work, the Dictionary of Natural Products [16]. Thus, the structurally most simple group of metabolites - derivatives of aliphatic hydrocarbons (branched, unbranched, saturated or unsaturated) with varying levels of oxidation at C-1 (alcohol, aldehyde, ketone, acid or ester) - are described first in Section 2.1. The next major group to be covered in Section 2.2 comprises derivatives of simple aromatic hydrocarbons. The phenylpropanoids, in which a $\mathrm{C}_{3}$ substituent is attached to the aromatic unit $\left(\mathrm{C}_{6}\right)$, form a biosynthetically distinct group of aromatic metabolites, which is described in Section 2.3. The flavonoids, which are biosynthetically derived from this same $\mathrm{C}_{6} \mathrm{C}_{3}$ precursor, constitute the second largest group of metabolites from $A$. annua, and are described separately in Section 2.4. By far the largest group of metabolites from A. annua is the terpenoids, which are biosynthetically derived from a branched isoprenoid unit $\left(\mathrm{C}_{5}\right)$. They have been further subdivided into monoterpenoids $\left(\mathrm{C}_{10}\right.$; i.e. $\left.2 \times \mathrm{C}_{5}\right)$; sesquiterpenoids $\left(\mathrm{C}_{15}\right.$; i.e. $\left.3 \times \mathrm{C}_{5}\right)$; and higher terpenoids (which include both diterpenes $\left(\mathrm{C}_{20}\right)$, triterpenes $\left(\mathrm{C}_{30}\right)$ and sterols $\left(\mathrm{C}_{29}\right)$. These large groupings are covered in Sections 2.5, 2.6 and 2.7, respectively. Finally, a very small number of miscellaneous nitrogen-containing natural products appear in Section 2.8.

The essential oil of $A$. annua was first studied as long ago as 1917 [17,18]. Researchers have continued to analyse the volatile constituents of this essential oil over the past century, primarily utilising gas chromatography (GC) and the hyphenated analytical technique of gas chromatographymass spectrometry (GC-MS) [19-35]. GC/GC-MS studies of the essential oil of A. annua have been reported from countries as diverse as France [36], Finland [37], Hungary [38], Romania [39], Kazakhstan [40], Iran [41,42], India [43-45], China [46-50] and Vietnam [51]. A detailed study of the essential oils from Chinese and Vietnamese varieties of $A$. annua demonstrated that the Chinese variety contained predominantly artemisia ketone, while the Vietnamese oil was dominated by 
camphor and germacrene D [21] (others have confirmed the absence of artemisia ketone from Vietnamese oil) [52]. Interestingly, this difference was also reflected in the artemisinin content of Chinese and Vietnamese plants at $0.17 \%$ and $1.0 \%$ dry weight, respectively. Others have reported a similar variation in essential oil content between varieties of $A$. annua $[53,54]$ and have concurred that differences in the essential oil composition should be ascribed to the existence of chemotypes (or chemical races) in this species [43] (see also Section 4.1).

GC-MS studies are particularly suited to the analysis of the more volatile components of the plant metabolome, such as the monoterpenes (Section 2.5) and some of the unfunctionalized sesquiterpene hydrocarbons which are reported in Section 2.6. The identification of a metabolite by GC-MS generally requires that its retention time and mass spectrum be matched with that of a known standard, which is recorded in a database. Using this thechnique, it is therefore possible to make a very rapid analysis of a large number of compounds employing a relatively small amount of plant material. Many of the simple aliphatic and aromatic metabolites which are reported in Sections 2.1 and 2.2 are actually comparatively minor components of the essential oil of $A$. annua, that have been identified solely on this basis. Although it is also possible to analyse more highly oxygenated sesquiterpenes, such as artemisinin and its biosynthetic precursors by GC-MS [55] (Section 2.6), these less volatile components are generally more easily isolated by liquid chromatography (LC) [15]. LC is definitely the technique of choice for the more non-volatile compounds of the extract of A. annua, which include flavonoids (Section 2.4), and many triterpenoids and sterols (Section 2.7). In the preparative mode, the LC techniques [56] of column chromatography and high performance liquid chromatography (HPLC) can provide sufficient material to allow for the subsequent structural elucidation of completely novel metabolites, when used in conjunction with techniques such as nuclear magnetic resonance (NMR) spectroscopy and X-ray crystallography. Most of the structures of the more highly oxygenated cadinane and amorphane sesquiterpenoids from A. annua which are reported in Section 2.6.3, were determined by this more powerful, but also more laborious approach. The majority of these components are unique to this species and several have turned out to be relevant to the biosynthesis of artemisinin.

The highly oxygenated nature of many of the terpenoid metabolites from A. annua has been stressed throughout this review, because of its perceived relevance to the biosynthesis of artemisinin. In particular, the reader's attention has been drawn to the unusually wide diversity of terpenoid allylic hydroperoxides and endoperoxides which have been recorded from this species. It is suggested that several of these peroxides result from the reaction of molecular oxygen with the tri-substituted double bond of an appropriate (and frequently abundant) mono- sesqui- or diterpene precursor. Thus, allylic hydroperoxides are found for monoterpenes (264 and 265; Section 2.5.1), sesquiterpenes (414 and 481; Section 2.6.3) and diterpenes (553; Section 2.7.1), all of which might be derived from abundant hydrocarbon precursors; in addition to one monoterpene endoperoxide (329; Section 2.5.3) and three sesquiterpene endoperoxides $(\mathbf{4 6 5}, 495$ and 497; Section 2.6.3). These reactive hydroperoxides might then be responsible for the formation of a large number of the highly-oxygenated terpenes reported from A. annua.

Finally, it has recently been proposed that the the yin-yang nature of Chinese herbal medicine might equate to antioxidation-oxidation in modern parlance [57]. If this is true, then the wide-ranging antioxidant properties associated with the various terpenoidal components from A. annua (i.e. their 
propensity to undergo spontaneous autoxidation) would be entirely consistent with its classification as a cooling herb in the TCM system.

\subsection{Aliphatic Hydrocarbons, Alcohols, Aldehydes and Acids}

All possible saturated unbranched hydrocarbons between $\mathrm{C}_{16}$ [hexadecane; (5)] and $\mathrm{C}_{26}$ [hexacosane; (14)] have now been reported from GC-MS studies of $A$. annua (Table 1).

Table 1. Saturated Unbranched Hydrocarbons.

\begin{tabular}{|l|l|l|l|}
\hline Structure & Name & CAS Number & References \\
\hline $\mathrm{CH}_{3}\left(\mathrm{CH}_{2}\right)_{3} \mathrm{CH}_{3}$ & Pentane (1) & {$[109-66-0]$} & {$[58]$} \\
$\mathrm{CH}_{3}\left(\mathrm{CH}_{2}\right)_{4} \mathrm{CH}_{3}$ & Hexane (2) & {$[110-54-3]$} & {$[22]$} \\
$\mathrm{CH}_{3}\left(\mathrm{CH}_{2}\right)_{10} \mathrm{CH}_{3}$ & Dodecane (3) & {$[112-40-3]$} & {$[24]$} \\
$\mathrm{CH}_{3}\left(\mathrm{CH}_{2}\right)_{11} \mathrm{CH}_{3}$ & Tridecane (4) & {$[629-50-5]$} & {$[24]$} \\
$\mathrm{CH}_{3}\left(\mathrm{CH}_{2}\right)_{14} \mathrm{CH}_{3}$ & Hexadecane (5) & {$[629-76-3]$} & {$[24]$} \\
$\mathrm{CH}_{3}\left(\mathrm{CH}_{2}\right)_{15} \mathrm{CH}_{3}$ & Heptadecane (6) & {$[593-45-3]$} & {$[27]$} \\
$\mathrm{CH}_{3}\left(\mathrm{CH}_{2}\right)_{16} \mathrm{CH}_{3}$ & Octadecane (7) & {$[629-92-5]$} & {$[32,43]$} \\
$\mathrm{CH}_{3}\left(\mathrm{CH}_{2}\right)_{17} \mathrm{CH}_{3}$ & Nonadecane (8) & {$[112-95-8]$} & {$[27,32,43]$} \\
$\mathrm{CH}_{3}\left(\mathrm{CH}_{2}\right)_{18} \mathrm{CH}_{3}$ & Eicosane (9) & {$[629-94-7]$} & {$[32,43]$} \\
$\mathrm{CH}_{3}\left(\mathrm{CH}_{2}\right)_{19} \mathrm{CH}_{3}$ & Heneicosane (10) & {$[638-67-5]$} & {$[32,34]$} \\
$\mathrm{CH}_{3}\left(\mathrm{CH}_{2}\right)_{21} \mathrm{CH}_{3}$ & Tricosane (11) & {$[646-31-1]$} & {$[32]$} \\
$\mathrm{CH}_{3}\left(\mathrm{CH}_{2}\right)_{22} \mathrm{CH}_{3}$ & Tetracosane (12) & {$[629-99-2]$} & {$[32]$} \\
$\mathrm{CH}_{3}\left(\mathrm{CH}_{2}\right)_{23} \mathrm{CH}_{3}$ & Pentacosane (13) & {$[630-01-3]$} & {$[32]$} \\
$\mathrm{CH}_{3}\left(\mathrm{CH}_{2}\right)_{24} \mathrm{CH}_{3}$ & Hexacosane (14) & {$[630-03-5]$} & {$[32]$} \\
$\mathrm{CH}_{3}\left(\mathrm{CH}_{2}\right)_{27} \mathrm{CH}_{3}$ & Nonocosane (15) & {$[14167-59-0]$} & {$[58]$} \\
$\mathrm{CH}_{3}\left(\mathrm{CH}_{2}\right)_{32} \mathrm{CH}_{3}$ & Tetratriacontane (16) & {$[59]$} \\
\hline
\end{tabular}

Table 2. Saturated Unbranched Alcohols, Aldehydes and Ketones.

\begin{tabular}{|c|c|c|c|c|}
\hline Structure & Name & Alternative Name(s) & CAS Number & References \\
\hline \multicolumn{5}{|l|}{ Alcohols } \\
\hline $\mathrm{CH}_{3}\left(\mathrm{CH}_{2}\right)_{3} \mathrm{CH}_{2} \mathrm{OH}$ & 1-Pentanol (17) & Pentyl alcohol & [71-41-0] & {$[24]$} \\
\hline $\mathrm{CH}_{3}\left(\mathrm{CH}_{2}\right)_{4} \mathrm{CH}_{2} \mathrm{OH}$ & $n$-Hexanol (18) & & {$[111-27-3]$} & {$[22,32,43]$} \\
\hline $\begin{array}{l}\mathrm{CH}_{3}\left(\mathrm{CH}_{2}\right)_{4} \mathrm{CH}_{2} \mathrm{O}- \\
(\mathrm{C}=\mathrm{O}) \mathrm{CH}_{2} \mathrm{CH}\left(\mathrm{CH}_{2}\right)_{2}\end{array}$ & $n$-Hexyl isovalerate (19) & 3-Methylbutyric acid hexyl ester & [10032-13-0] & {$[32,43]$} \\
\hline $\mathrm{CH}_{3}\left(\mathrm{CH}_{2}\right)_{4} \mathrm{CH}_{2} \mathrm{O}-$ & $n$-Hexyl tiglate $(\mathbf{2 0})$ & (2E)-2-Butenoic acid, 2-methyl-, hexyl & [16930-96-4] & {$[32,43]$} \\
\hline $\begin{array}{l}(\mathrm{C}=\mathrm{O}) \mathrm{C}\left(\mathrm{CH}_{3}\right)=\mathrm{CHCH} \mathrm{H}_{3} \\
\mathrm{CH}_{3}\left(\mathrm{CH}_{2}\right)_{6} \mathrm{CH}_{2} \mathrm{OH}\end{array}$ & 1-Octanol (21) & $\begin{array}{l}\text { ester } \\
\text { Caprylic alcohol }\end{array}$ & {$[111-87-5]$} & {$[24]$} \\
\hline $\mathrm{CH}_{3}\left(\mathrm{CH}_{2}\right)_{7} \mathrm{CH}_{2} \mathrm{OH}$ & $n$-Nonyl alcohol (22) & 1-Nonanol & [143-08-8] & {$[24]$} \\
\hline $\mathrm{CH}_{3}\left(\mathrm{CH}_{2}\right)_{26} \mathrm{CH}_{2} \mathrm{OH}$ & Octacosanol (23) & & [557-61-9] & {$[59,60,61]$} \\
\hline $\mathrm{CH}_{3}\left(\mathrm{CH}_{2}\right)_{27} \mathrm{CH}_{2} \mathrm{OH}$ & Nonacosanol (24) & & [6624-76-6] & {$[59,62]$} \\
\hline \multicolumn{5}{|l|}{ Aldehydes and Ketones } \\
\hline $\mathrm{CH}_{3} \mathrm{COCH}_{3}$ & Acetone $(\mathbf{2 5})$ & 2-Propanone & {$[67-64-1]$} & {$[24]$} \\
\hline $\mathrm{CH}_{3}\left(\mathrm{CH}_{2}\right)_{2} \mathrm{CHO}$ & Butanal (26) & Butyraldehyde & & {$[50]$} \\
\hline $\mathrm{CH}_{3}\left(\mathrm{CH}_{2}\right)_{4} \mathrm{CHO}$ & Hexanal (27) & Caproic aldehyde & {$[66-25-1]$} & [23] \\
\hline $\mathrm{CH}_{3} \mathrm{CO}\left(\mathrm{CH}_{2}\right)_{4} \mathrm{CH}_{3}$ & 2-Heptanone (28) & Methyl pentyl ketone & [110-43-0] & [45] \\
\hline $\mathrm{CH}_{3}\left(\mathrm{CH}_{2}\right)_{6} \mathrm{CHO}$ & Octanal (29) & Capric aldehyde & {$[124-13-0]$} & [32] \\
\hline $\mathrm{CH}_{3}\left(\mathrm{CH}_{2}\right)_{11} \mathrm{CHO}$ & Tridecanal (30) & Tridecyl aldehyde & [10486-19-8] & [24] \\
\hline
\end{tabular}

The saturated fatty acids listed in Table 3 are likely to be the biogenetic parents of the saturated hydrocarbons, alcohols, aldehydes and ketones which appear in Tables 1 and 2. Saturated fatty acids have been obtained from $A$. annua as a continuous series between $\mathrm{C}_{12}$ [dodecanoic acid; (36)] and $\mathrm{C}_{20}$ [eicosanoic acid; (48)]. Hexadecanoic acid $\left(\mathbf{4 1} ; \mathrm{C}_{16}\right)$ and octadecanoic acid $\left(\mathbf{4 5} ; \mathrm{C}_{18}\right)$ are the most dominant saturated lipids from A. annua (Table 3), while oleic acid $(\mathbf{8 0})\left(\mathrm{C}_{18}\right)$ is the most abundant unsaturated fatty acid (Table 5). 
Table 3. Saturated Unbranched Carboxylic Acids and Esters.

\begin{tabular}{|c|c|c|c|c|}
\hline Structure & Name & Alternative Name(s) & CAS Number & References \\
\hline $\mathrm{CH}_{3} \mathrm{CH}_{2} \mathrm{OCHO}$ & Ethyl formate (31) & & {$[109-94-4]$} & {$[50]$} \\
\hline $\mathrm{CH}_{3} \mathrm{CH}_{2} \mathrm{CO}_{2} \mathrm{CH}_{2} \mathrm{CH}_{3}$ & Propanoic acid, ethyl ester (32) & Ethyl propionate & {$[105-37-3]$} & [50] \\
\hline $\mathrm{CH}_{3}\left(\mathrm{CH}_{2}\right)_{3} \mathrm{CO}_{2} \mathrm{H}$ & Pentanoic acid (33) & Valeric acid & [109-52-4] & [24] \\
\hline $\mathrm{CH}_{3}\left(\mathrm{CH}_{2}\right)_{3} \mathrm{CO}_{2} \mathrm{C}\left(\mathrm{CH}_{3}\right)_{3}$ & Pentanoic acid, tert-butyl ester (34) & $\begin{array}{l}\text { Pentanoic acid, } 1,1- \\
\text { dimethylethyl ester }\end{array}$ & {$[23361-78-6]$} & [50] \\
\hline $\mathrm{CH}_{3}\left(\mathrm{CH}_{2}\right)_{8} \mathrm{CO}_{2} \mathrm{H}$ & Decanoic acid (35) & Capric acid & {$[334-48-5]$} & {$[63,64]$} \\
\hline $\mathrm{CH}_{3}\left(\mathrm{CH}_{2}\right)_{10} \mathrm{CO}_{2} \mathrm{H}$ & Dodecanoic acid (36) & Lauric acid & [143-07-7] & {$[63,64]$} \\
\hline $\mathrm{CH}_{3}\left(\mathrm{CH}_{2}\right)_{10} \mathrm{CO}_{2} \mathrm{CH}_{2} \mathrm{CH}_{3}$ & Dodecanoic acid, ethyl ester (37) & Ethyl laurate & [106-33-2] & {$[24]$} \\
\hline $\mathrm{CH}_{3}\left(\mathrm{CH}_{2}\right)_{11} \mathrm{CO}_{2} \mathrm{H}$ & Tridecanoic acid (38) & & [638-53-9] & [63] \\
\hline $\mathrm{CH}_{3}\left(\mathrm{CH}_{2}\right)_{12} \mathrm{CO}_{2} \mathrm{H}$ & Tetradecanoic acid (39) & Myristic acid & {$[544-63-8]$} & {$[23,63,64]$} \\
\hline $\mathrm{CH}_{3}\left(\mathrm{CH}_{2}\right)_{13} \mathrm{CO}_{2} \mathrm{H}$ & Pentadecanoic acid (40) & & {$[1002-84-2]$} & {$[63]$} \\
\hline $\mathrm{CH}_{3}\left(\mathrm{CH}_{2}\right)_{14} \mathrm{CO}_{2} \mathrm{H}$ & Hexadecanoic acid (41) & Palmitic acid & {$[57-10-3]$} & $\begin{array}{l}{[20,23,24,27,32,} \\
43,63,64,65]\end{array}$ \\
\hline $\mathrm{CH}_{3}\left(\mathrm{CH}_{2}\right)_{14} \mathrm{CO}_{2} \mathrm{CH}_{3}$ & $\begin{array}{l}\text { Hexadecanoic acid, methyl ester } \\
\text { (42) }\end{array}$ & $\begin{array}{l}\text { Methyl hexadecanoate } \\
\text { Methyl palmitate }\end{array}$ & {$[112-39-0]$} & [27] \\
\hline $\mathrm{CH}_{3}\left(\mathrm{CH}_{2}\right)_{14} \mathrm{CO}_{2} \mathrm{CH}_{2} \mathrm{CH}_{3}$ & Hexadecanoic acid, ethyl ester (43) & Ethyl palmitate & {$[628-97-7]$} & {$[24]$} \\
\hline $\mathrm{CH}_{3}\left(\mathrm{CH}_{2}\right)_{15} \mathrm{CO}_{2} \mathrm{H}$ & Heptadecanoic acid (44) & Margaric acid & [506-12-7] & [63] \\
\hline $\mathrm{CH}_{3}\left(\mathrm{CH}_{2}\right)_{16} \mathrm{CO}_{2} \mathrm{H}$ & Octadecanoic acid (45) & Stearic acid & {$[57-11-4]$} & {$[27,43,63,64]$} \\
\hline $\mathrm{CH}_{3}\left(\mathrm{CH}_{2}\right)_{16} \mathrm{CO}_{2} \mathrm{CH}_{3}$ & Octadecanoic acid, methyl ester (46) & $\begin{array}{l}\text { Methyl octadecanoate } \\
\text { Methyl stearate }\end{array}$ & [112-61-8] & [27] \\
\hline $\mathrm{CH}_{3}\left(\mathrm{CH}_{2}\right)_{17} \mathrm{CO}_{2} \mathrm{H}$ & Nonadecanoic acid (47) & & {$[646-30-0]$} & {$[20]$} \\
\hline $\mathrm{CH}_{3}\left(\mathrm{CH}_{2}\right)_{18} \mathrm{CO}_{2} \mathrm{H}$ & Eicosanoic acid (48) & Arachidic acid & [506-30-9] & [64] \\
\hline $\mathrm{CH}_{3}\left(\mathrm{CH}_{2}\right)_{20} \mathrm{CO}_{2} \mathrm{H}$ & Docosanoic acid (49) & Behenic acid & {$[112-85-6]$} & [64] \\
\hline $\mathrm{CH}_{3}\left(\mathrm{CH}_{2}\right)_{22} \mathrm{CO}_{2} \mathrm{H}$ & Tetracosanoic acid (50) & Lignoceric acid & {$[557-59-5]$} & [64] \\
\hline $\mathrm{CH}_{3}\left(\mathrm{CH}_{2}\right)_{28} \mathrm{CO}_{2}\left(\mathrm{CH}_{2}\right)_{30} \mathrm{CH}_{3}$ & Hentriacontanyl triacontanoate $\mathbf{( 5 1 )}$ & $\begin{array}{l}\text { Triacontanoic acid } \\
\text { hentriacontyl ester }\end{array}$ & {$[135729-36-1]$} & {$[59,62]$} \\
\hline
\end{tabular}

Table 4. Unbranched Alkenic Hydrocarbons and Alcohols.

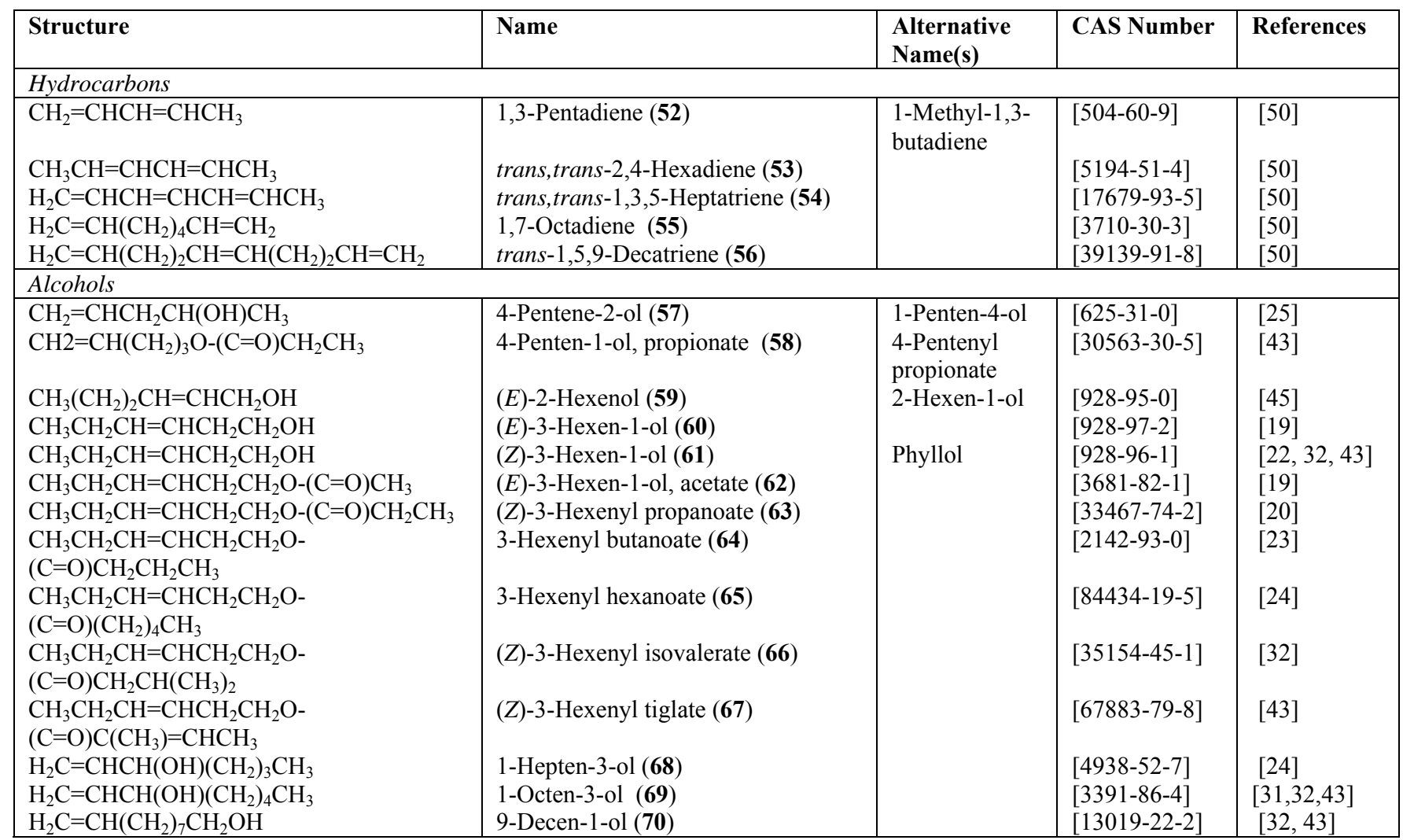


Table 5. Unbranched Alkenic Ketones, Aldehydes, Carboxylic acids and Esters.

\begin{tabular}{|c|c|c|c|c|}
\hline Structure & Name & $\begin{array}{l}\text { Alternative } \\
\text { ame(s) }\end{array}$ & $\begin{array}{l}\text { CAS } \\
\text { Number }\end{array}$ & References \\
\hline \multicolumn{5}{|l|}{ Ketones and aldehydes } \\
\hline $\mathrm{H}_{2} \mathrm{C}=\mathrm{CHCH}_{2} \mathrm{CH}_{2} \mathrm{CHO}$ & 4-Pentenal (71) & & [2100-17-6] & {$[50]$} \\
\hline $\mathrm{CH}_{3}\left(\mathrm{CH}_{2}\right)_{2} \mathrm{CH}=\mathrm{CHCHO}$ & 2-Hexenal (72) & Leaf aldehyde & $\begin{array}{l}{[505-57-7]} \\
{[6728-26-3]}\end{array}$ & $\begin{array}{l}{[24,} \\
43]\end{array}$ \\
\hline $\mathrm{CH}_{3}\left(\mathrm{CH}_{2}\right)_{3} \mathrm{CH}=\mathrm{CHCHO}$ & 2-Heptenal (73) & & [2463-63-0] & {$[24]$} \\
\hline $\mathrm{CH}_{3}\left(\mathrm{CH}_{2}\right)_{5} \mathrm{CH}=\mathrm{CHCHO}$ & (Z)-2-Nonenal (74) & & [60784-31-8] & {$[50]$} \\
\hline $\mathrm{CH}_{3}\left(\mathrm{CH}_{2}\right)_{3} \mathrm{CH}=\mathrm{CHCH}=\mathrm{CHCHO}$ & $(2 E, 4 E)$ - Nonadienal (75) & & {$[5910-87-2]$} & [19] \\
\hline $\mathrm{CH}_{3}\left(\mathrm{CH}_{2}\right)_{4} \mathrm{CH}=\mathrm{CHCOCH}_{3}$ & 3-Nonen-2-one (76) & & [14309-57-0] & [24] \\
\hline $\mathrm{CH}_{3}\left(\mathrm{CH}_{2}\right)_{6} \mathrm{CH}=\mathrm{CHCHO}$ & 2-Decenal (77) & & [3913-71-1] & [24] \\
\hline $\mathrm{CH}_{3}\left(\mathrm{CH}_{2}\right)_{4} \mathrm{CH}=\mathrm{CHCH}=\mathrm{CHCHO}$ & 2,4-Decadienal (78) & & {$[2363-88-4]$} & [24] \\
\hline $\mathrm{H}_{2} \mathrm{C}=\mathrm{CH}\left(\mathrm{CH}_{2}\right)_{8} \mathrm{CHO}$ & 10-Undecenal (79) & & {$[112-45-8]$} & [24] \\
\hline \multicolumn{5}{|l|}{ Carboxylic acids and esters } \\
\hline $\mathrm{CH}_{3}\left(\mathrm{CH}_{2}\right)_{7} \mathrm{CH}=\mathrm{CH}\left(\mathrm{CH}_{2}\right)_{7} \mathrm{CO}_{2} \mathrm{H}$ & Oleic acid (80) & $\begin{array}{l}\text { (Z)-9- } \\
\text { Octadecanoic acid }\end{array}$ & $\begin{array}{l}{[112-80-1]} \\
{[27104-13-8]}\end{array}$ & {$[28,63,64]$} \\
\hline $\mathrm{CH}_{3}\left(\mathrm{CH}_{2}\right)_{7} \mathrm{CH}=\mathrm{CH}\left(\mathrm{CH}_{2}\right)_{7} \mathrm{CO}_{2} \mathrm{CH}_{3}$ & $\begin{array}{l}\text { Methyl 9-octadecenoate } \\
\text { (81) }\end{array}$ & Methyl elaidate & {$[2462-84-2]$} & {$[24]$} \\
\hline $\mathrm{CH}_{3}\left(\mathrm{CH}_{2}\right)_{7} \mathrm{CH}=\mathrm{CH}\left(\mathrm{CH}_{2}\right)_{7} \mathrm{CO}_{2} \mathrm{CH}_{2} \mathrm{CH}(\mathrm{OH}) \mathrm{CH}_{2} \mathrm{OH}$ & $\begin{array}{l}\text { 9-Octadecenoic acid, 2,3- } \\
\text { dihydroxypropyl ester } \\
(\mathbf{8 2})\end{array}$ & & $\begin{array}{l}{[251983-54-} \\
7]\end{array}$ & {$[24]$} \\
\hline $\mathrm{CH}_{3}\left(\mathrm{CH}_{2}\right)_{4} \mathrm{CH}=\mathrm{CHCH}_{2} \mathrm{CH}=\mathrm{CH}\left(\mathrm{CH}_{2}\right)_{7} \mathrm{CO}_{2} \mathrm{H}$ & Linoleic acid (83) & $\begin{array}{l}(Z, Z)-9,12- \\
\text { Octadecadienoic } \\
\text { acid }\end{array}$ & $\begin{array}{l}{[60-33-3]} \\
{[27213-43-0]} \\
{[28984-77-2]}\end{array}$ & {$[20,63]$} \\
\hline $\mathrm{CH}_{3} \mathrm{CH}_{2} \mathrm{CH}=\mathrm{CHCH}_{2} \mathrm{CH}=\mathrm{CHCH}_{2} \mathrm{CH}=\mathrm{CH}\left(\mathrm{CH}_{2}\right)_{7} \mathrm{CO}_{2} \mathrm{H}$ & $\alpha$-Linolenic acid (84) & $\begin{array}{l}(Z, Z, Z)-9,12,15- \\
\text { Octadecatrien-oic } \\
\text { acid }\end{array}$ & {$[463-40-1]$} & {$[20,63]$} \\
\hline
\end{tabular}

Table 6. Branched Aliphatic Hydrocarbons and Alcohols.

\begin{tabular}{|c|c|c|c|c|}
\hline Structure & Name & Alternative Name(s) & CAS Number & References \\
\hline \multicolumn{5}{|l|}{ Hydrocarbons } \\
\hline $\mathrm{CH}_{3}\left(\mathrm{CH}_{2}\right)_{8} \mathrm{CH}\left(\mathrm{CH}_{3}\right) \mathrm{CH}_{2} \mathrm{CH}_{2} \mathrm{CH}\left(\mathrm{CH}_{3}\right)_{2}$ & Tetradecane, 2,5-dimethyl- (85) & \multirow{3}{*}{ 2,29-Dimethyltriacontane } & {$[56292-69-4]$} & [24] \\
\hline$\left(\mathrm{CH}_{3}\right)_{2} \mathrm{CH}\left(\mathrm{CH}_{2}\right)_{26} \mathrm{CH}\left(\mathrm{CH}_{3}\right)_{2}$ & Triacontane, 2,29-dimethyl- (86) & & [135729-37-2] & [62] \\
\hline$\left(\mathrm{CH}_{3}\right)_{2} \mathrm{CHC}\left(\mathrm{CH}_{3}\right)_{3}$ & 2,2,3-Trimethylbutane $(\mathbf{8 7})$ & & [464-06-2] & [50] \\
\hline $\begin{array}{l}\mathrm{CH}_{3}\left(\mathrm{CH}_{2}\right)_{3} \mathrm{CH}\left(\mathrm{CH}_{3}\right)\left(\mathrm{CH}_{2}\right)_{7} \mathrm{CH}_{3} \\
\text { Alcohols }\end{array}$ & Tridecane, 5-methyl- (88) & 5-Methyltridecane & [25117-31-1] & [24] \\
\hline$\left(\mathrm{CH}_{3}\right)_{2} \mathrm{CHCH}_{2} \mathrm{CH}_{2} \mathrm{O}-(\mathrm{C}=\mathrm{O}) \mathrm{CH}_{3}$ & 3-Methyl-1-butanol, acetate (89) & Isoamyl acetate & [123-92-2] & [43] \\
\hline$\left(\mathrm{CH}_{3}\right)_{2} \mathrm{CHCH}_{2} \mathrm{O}-(\mathrm{C}=\mathrm{O}) \mathrm{CH}_{2} \mathrm{CH}_{3}$ & 2-methylpropylpropionate (90) & \multirow[t]{3}{*}{ Isobutyl propionate } & [540-42-1] & [50] \\
\hline$\left(\mathrm{CH}_{3}\right)_{2} \mathrm{C}(\mathrm{OH})\left(\mathrm{CH}_{2}\right)_{2} \mathrm{CH}_{3}$ & 2-Methyl-2-pentanol (91) & & [590-36-3] & [25] \\
\hline$\left(\mathrm{CH}_{3}\right)_{2} \mathrm{C}(\mathrm{OH})\left(\mathrm{CH}_{2}\right)_{3} \mathrm{CH}_{3}$ & 2-Methyl-2-hexanol (92) & & {$[625-23-0]$} & [24] \\
\hline$\left(\mathrm{CH}_{3}\right)_{2} \mathrm{CH}\left(\mathrm{CH}_{2}\right)_{3} \mathrm{CH}_{2} \mathrm{OH}$ & 5-Methyl-1-hexanol (93) & 1-Hexanol, 5-methyl- & [627-98-5] & [24] \\
\hline \multicolumn{5}{|l|}{ Aldehydes and Ketones } \\
\hline$\left(\mathrm{CH}_{3}\right)_{2} \mathrm{CHCH}_{2} \mathrm{CHO}$ & 3-Methylbutanal (94) & \multirow{5}{*}{$\begin{array}{l}\text { Isovaleraldehyde } \\
\text { Isobutyl methyl ketone } \\
\text { Benzenepropanal, } \alpha \text { - } \\
\text { hexyl- }\end{array}$} & [590-86-3] & [24] \\
\hline $\mathrm{CH}_{3} \mathrm{CH}_{2} \mathrm{CH}\left(\mathrm{CH}_{3}\right) \mathrm{CH}_{2} \mathrm{CHO}$ & 3-Methylpentanal (95) & & [15877-57-3] & [20] \\
\hline$\left(\mathrm{CH}_{3}\right)_{2} \mathrm{CHCH}_{2} \mathrm{COCH}_{3}$ & 4-Methyl-2-pentanone (96) & & {$[108-10-1]$} & [24] \\
\hline$\left(\mathrm{C}_{6} \mathrm{H}_{5}\right) \mathrm{CH}_{2} \mathrm{CH}(\mathrm{CHO})\left(\mathrm{CH}_{2}\right)_{5} \mathrm{CH}_{3}$ & 2-Benzyloctanal (97) & & [161403-65-2] & [24] \\
\hline$\left(\mathrm{CH}_{3}\right)_{2} \mathrm{CH}\left(\mathrm{CH}_{2}\right)_{5} \mathrm{C}=\mathrm{O}\left(\mathrm{CH}_{2}\right)_{14} \mathrm{CH}_{2} \mathrm{OH}$ & $\begin{array}{l}\text { 8-Tricosanone, 23-hydroxy-2- } \\
\text { methyl- }(\mathbf{9 8})\end{array}$ & & {$[135729-35-0]$} & {$[59,62]$} \\
\hline
\end{tabular}

Table 7. Branched Aliphatic Carboxylic Acids, Esters and Anhydrides.

\begin{tabular}{|l|l|l|l|l|}
\hline Structure & Name & Alternative Name(s) & CAS Number & References \\
\hline $\mathrm{CH}_{3} \mathrm{CH}_{2} \mathrm{CH}\left(\mathrm{CH}_{3}\right) \mathrm{CO}_{2} \mathrm{H}$ & $\begin{array}{l}\text { 2-Methylbutanoic acid (99) } \\
\text { 2-Methyl butanoic acid, ethyl }\end{array}$ & Ethyl 2-methylbutyrate & {$[868-57-5]$} \\
$\mathrm{CH}_{3} \mathrm{CH}_{2} \mathrm{CH}\left(\mathrm{CH}_{3}\right) \mathrm{CO}_{2} \mathrm{CH}_{2} \mathrm{CH}_{3}$ & $\begin{array}{l}{[7452-79-1]} \\
{[22]}\end{array}$ & {$[22,32]$} \\
$\left(\mathrm{CH}_{3} \mathrm{CH}_{2} \mathrm{CH}\left(\mathrm{CH}_{3}\right) \mathrm{CO}_{2}\right) \mathrm{O}$ & $\begin{array}{l}\text { 2-Methylbutanoic acid anhydride } \\
(\mathbf{1 0 1})\end{array}$ & $\begin{array}{l}\text { 2-Methylbutyryl } \\
\text { anhydride }\end{array}$ & {$[1519-23-9]$} \\
$\mathrm{CH}_{3} \mathrm{CH}_{2} \mathrm{CH}\left(\mathrm{CH}_{3}\right) \mathrm{CO}_{2}\left(\mathrm{CH}_{2}\right)_{4} \mathrm{CH}_{3}$ & Amyl 2-methylbutyrate (102) & $\begin{array}{l}\text { Pentyl 2- } \\
\text { methylbutanoate }\end{array}$ & {$[50]$} \\
$\mathrm{CH}_{3} \mathrm{CH}_{2} \mathrm{CH}\left(\mathrm{CH}_{3}\right) \mathrm{CO}_{2} \mathrm{CH}_{2} \mathrm{CH}\left(\mathrm{CH}_{3}\right) \mathrm{CH}_{2} \mathrm{CH}_{3}$ & $\begin{array}{l}\text { 2-Methylbutyl 2- } \\
\text { 2-Methyl-butanoic acid, 2- }\end{array}$ & {$[68039-26-9]$} \\
{$[2445-78-5]$} \\
{$\left[\begin{array}{l}\text { methylbutyl ester (103) } \\
{[31]}\end{array}\right.$} \\
\hline
\end{tabular}


Table 7. Cont.

\begin{tabular}{|c|c|c|c|c|}
\hline$\left(\mathrm{CH}_{3}\right)_{2} \mathrm{CHCH}_{2} \mathrm{CO}_{2} \mathrm{CH}_{2} \mathrm{CH}_{3}$ & $\begin{array}{l}\text { 3-Methylbutanoic acid, ethyl } \\
\text { ester (104) }\end{array}$ & $\begin{array}{l}\text { Ethyl 3- } \\
\text { methylbutanoate } \\
\text { Ethyl isovalerate }\end{array}$ & [108-64-5] & [23] \\
\hline$\left(\mathrm{CH}_{3}\right)_{2} \mathrm{CHCH}_{2} \mathrm{CO}_{2}\left(\mathrm{CH}_{2}\right)_{3} \mathrm{CH}_{3}$ & $\begin{array}{l}\text { 3-Methylbutanoic acid, butyl } \\
\text { ester (105) }\end{array}$ & $\begin{array}{l}\text { Butyl-3- } \\
\text { methylbutanoate }\end{array}$ & [109-19-3] & [25] \\
\hline$\left(\mathrm{CH}_{3}\right)_{2} \mathrm{CHCH}_{2} \mathrm{CO}_{2} \mathrm{CH}_{2} \mathrm{CH}_{2} \mathrm{C}\left(=\mathrm{CH}_{2}\right) \mathrm{CH}_{3}$ & $\begin{array}{l}\text { 3-Methylbutanoic acid, 3- } \\
\text { methyl-3-butenyl ester (106) }\end{array}$ & $\begin{array}{l}\text { 3-Methyl-3-butenyl 3- } \\
\text { methylbutyrate }\end{array}$ & [54410-94-5] & [20] \\
\hline $\mathrm{CH}_{3} \mathrm{CH}_{2} \mathrm{CH}\left(\mathrm{CH}_{2} \mathrm{CH}_{3}\right) \mathrm{CO}_{2} \mathrm{CH}_{3}$ & $\begin{array}{l}\text { 2-Ethylbutanoic acid, methyl } \\
\text { ester (107) }\end{array}$ & $\begin{array}{l}\text { 2-Methyl- } \\
\text { ethylbutanoate }\end{array}$ & [816-11-5] & [25] \\
\hline
\end{tabular}

Table 8. Branched Alkenic Hydrocarbons and Aldehydes.

\begin{tabular}{|c|c|c|c|c|}
\hline Structure & Name & Alternative Name(s) & $\begin{array}{l}\text { CAS } \\
\text { Number }\end{array}$ & References \\
\hline \multicolumn{5}{|l|}{ Hydrocarbons } \\
\hline $\mathrm{H}_{2} \mathrm{C}=\mathrm{CHC}\left(\mathrm{CH}_{3}\right)_{3}$ & 3,3-Dimethyl-1-butene (108) & tert-Butylethylene & {$[558-37-2]$} & {$[20]$} \\
\hline $\mathrm{H}_{2} \mathrm{C}=\mathrm{CHCH}\left(\mathrm{CH}_{3}\right)_{2}$ & 2,4-Dimethyl-2-pentene (109) & & {$[625-65-0]$} & {$[24]$} \\
\hline $\mathrm{CH}_{3} \mathrm{CH}=\mathrm{CHCH}\left(\mathrm{CH}_{3}\right) \mathrm{CH}_{2} \mathrm{CH}_{3}$ & trans-4-Methyl-2-hexene (110) & & {$[3683-22-5]$} & {$[20]$} \\
\hline \multicolumn{5}{|l|}{ Aldehydes } \\
\hline $\begin{array}{l}\mathrm{CH}_{3}\left(\mathrm{CH}_{2}\right)_{4} \mathrm{CH}=\mathrm{CH}(\mathrm{CHO})\left(\mathrm{CH}_{2}\right)_{3} \mathrm{CH}_{3} \\
\left(\mathrm{CH}_{3}\right)_{2} \mathrm{C}=\mathrm{CHCH}=\mathrm{CH}(\mathrm{C}=\mathrm{O}) \mathrm{CH}_{3}\end{array}$ & $\begin{array}{l}\text { 2-Butyl-2-octenal (111) } \\
\text { 6-Methyl-3,5-heptadien-2-one (112) }\end{array}$ & & $\begin{array}{l}{[13019-16-4]} \\
{[16647-04-4]}\end{array}$ & $\begin{array}{l}{[24]} \\
{[66]}\end{array}$ \\
\hline
\end{tabular}

Artemisia annua contains relatively few polyacetylenes by comparison with other members of the genus Artemisia (and also as compared to other members of the Asteraceae family). The only two such compounds to be reported to date are ponticaepoxide (121) and annuadiepoxide (122), which have been isolated from both leaves [67] and seeds [9] of A. annua.

Table 9. Acetylenic Hydrocarbons.

\begin{tabular}{|c|c|c|c|c|}
\hline Structure & Name & Alternative Name(s) & CAS Number & References \\
\hline $\begin{array}{l}\mathrm{CH}_{3} \mathrm{C} \equiv \mathrm{CCH}_{2} \mathrm{OMe} \\
\mathrm{H}_{2} \mathrm{C}=\mathrm{CH}\left(\mathrm{CH}_{2}\right)_{3} \mathrm{C} \equiv \mathrm{CH} \\
\mathrm{CH}_{3} \mathrm{O}(\mathrm{C}=\mathrm{O}) \mathrm{C} \equiv \mathrm{C}\left(\mathrm{CH}_{2}\right)_{5} \mathrm{CH}_{3} \\
\mathrm{CH}_{3}\left(\mathrm{CH}_{2}\right)_{9} \mathrm{C} \equiv \mathrm{CH} \\
\mathrm{CH}_{3} \mathrm{C} \equiv \mathrm{C}\left(\mathrm{CH}_{2}\right)_{8} \mathrm{CH}_{2} \mathrm{OH} \\
\left(\mathrm{CH}_{3}\right)_{2} \mathrm{CHC} \equiv \mathrm{CCH}=\mathrm{CHCH}\left(\mathrm{CH}_{3}\right)_{2} \\
\mathrm{CH}_{3}\left(\mathrm{CH}_{2}\right)_{6} \mathrm{CH}=\mathrm{CHC} \equiv \mathrm{CH}_{3} \\
\left(\mathrm{C}_{6} \mathrm{H}_{5}\right) \mathrm{CH}_{2} \mathrm{C} \equiv \mathrm{C}-\mathrm{C} \equiv \mathrm{C}-\mathrm{CH}_{3}\end{array}$ & $\begin{array}{l}\text { 1-Methoxy-2-butyne } \\
\text { (113) } \\
\text { 1-Hepten-6-yne (114) } \\
\text { 2-Nonynoic cid, methyl } \\
\text { ester (115) } \\
\text { 1-Dodecyne (116) } \\
\text { 10-Dodecyn-1-ol (117) } \\
\text { 3-Octen-5-yne, 2,7- } \\
\text { dimethyl- (118) } \\
\text { 3-Undecen-1-yne (119) } \\
\text { Capillene (120) } \\
\text { Ponticaepoxide (121) } \\
\text { Annuadiepoxide (122) }\end{array}$ & $\begin{array}{l}\text { 2,4-Hexadiynylbenzene } \\
\text { 2-Ethenyl-3-(1-nonen-3,5,7- } \\
\text { triynyl)oxirane } \\
\text { 2-(1-Nonen-3,5,7-triynyl)-3- } \\
\text { vinyloxirane } \\
\text { 3,4-Epoxy-1,5-tridecadiene- } \\
\text { 7,9,11-triyne } \\
\text { 1,3,5-Tridecatriene-7,9,11-triyne } \\
\text { (E,E), 3,4:5,6-diepoxide } \\
\text { 3,4:5,6-Diepoxy-1-tridecene- } \\
\text { 7,9,11-triyne }\end{array}$ & $\begin{array}{l}{[65939-59-5]} \\
{[111-80-8]} \\
{[765-03-7]} \\
{[69221-99-4]} \\
{[91400-77-0]} \\
\\
{[74744-32-4]} \\
{[91250-91-8]} \\
{[520-74-1]} \\
{[3562-36-5]}\end{array}$ & $\begin{array}{l}{[50]} \\
{[50]} \\
{[23]} \\
{[23]} \\
{[50]} \\
{[23]} \\
{[30]} \\
{[9,67]}\end{array}$ \\
\hline
\end{tabular}

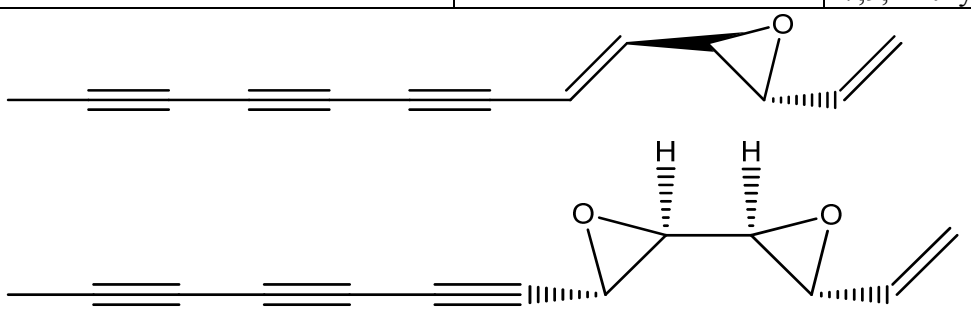


Table 10. Cyclic Hydrocarbons.

\begin{tabular}{|c|c|c|c|}
\hline Name & Alternative Name(s) & CAS Number & References \\
\hline 1,1'-Bicyclopropyl, 2,2'-dimethyl (123) & & [1975-84-6] & [23] \\
\hline Bicyclo[2.2.2] octa-2,5-diene, 1,2,3,6-tetramethyl- (124) & & {$[62338-43-6]$} & [20] \\
\hline 3,5-Cycloheptadienone (125) & & [1121-65-9] & [28] \\
\hline Cyclooctane, 1,4-dipropyl- (126) & & [251983-53-6] & [24] \\
\hline Cyclopropane, (1-methyl-1,2-propadien-1-yl)- (127) & 3-Cyclopropyl-1,2-butadiene & {$[51549-86-1]$} & {$[50]$} \\
\hline Cyclopropene, 3-ethenyl-3-methyl-(128) & 3-Methyl-3-vinylcyclopropene & {$[71153-30-5]$} & \\
\hline 1,1-Dicyclopropylethylene (129) & Cyclopropane, 1,1'-ethenylidenebis- & [822-93-5] & {$[50]$} \\
\hline Hexylcyclohexane (130) & & {$[4292-75-5]$} & {$[20]$} \\
\hline Jasmone (131) & 3-Methyl-2-(2-pentenyl)-2-cyclopenten-1-one & {$[488-10-8]$} & {$[22,32,43]$} \\
\hline Methyl cyclopentane (132) & & {$[96-37-7]$} & {$[22]$} \\
\hline
\end{tabular}

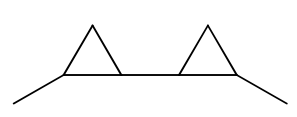

(123)

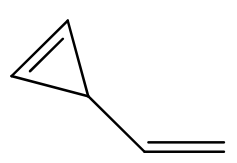

(128)

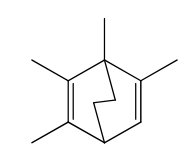

(124)

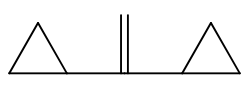

(129)

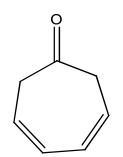

(125)<smiles>CCCCCCC1CCCCC1</smiles>

(130)

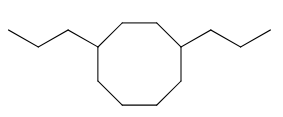

(126)<smiles>C=C1CCC(C)=C1C/C=C/CC</smiles>

(131)

Table 11. Furans.

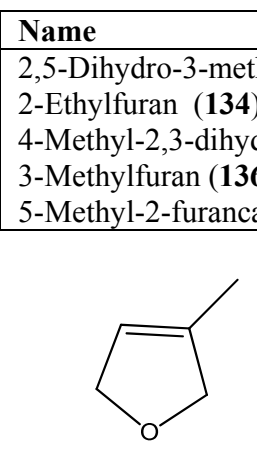

(133)<smiles>CCc1ccco1</smiles>

(134)

5-Methylfurf

(135)<smiles>Cc1ccoc1</smiles>

(136)<smiles>Cc1ccc(C=O)o1</smiles>

(137)

\subsection{Aromatic Alcohols, Ketones and Acids}

The simple aromatic compounds described in Tables 12, 13 and 14 form a relatively small group of natural products from A. annua. Metabolites in this section are probably biosynthesised by both the polyketide and shikimate pathways (some simple aromatics which are derived from the terpenoid pathway are discussed separately in Section 2.5.3).

Table 12. Simple Phenols and Benzylic Alcohols.

\begin{tabular}{|l|l|l|l|}
\hline Name & Alternative Name(s) & CAS Number & References \\
\hline Anisole (138) & Phenyl methyl ether & {$[100-66-3]$} & {$[48]$} \\
Benzyl isovalerate (139) & 3-Methylbutanoic acid, benzyl ester & {$[103-38-8]$} & {$[22,23,25,32,43]$} \\
Benzyl 2-methyl butyrate (140) & 2-Methylbutanoic acid, benzyl ester & {$[56423-40-6]$} & {$[41]$} \\
Benzyl phenylacetate (141) & Benzeneacetic acid, phenylmethyl ester & {$[102-16-9]$} & {$[50]$} \\
Benzyl valerate (142) & Benzyl pentanoate & {$[10361-39-4]$} & {$[19,23]$} \\
5-Nonadecylresorcinol-3-O-methyl ether (143) & Phenol 3-methoxy-5-nonadecyl & & {$[68]$} \\
\hline
\end{tabular}


<smiles>COc1ccccc1</smiles>

(138)<smiles>[R]OCc1ccccc1</smiles>

(139-142)
Tabel 12. Cont.

$139 \mathrm{R}=$<smiles>CC(C)CC=O</smiles>

$140 \mathrm{R}=$<smiles>CCC(C)C=O</smiles>

$141 \mathrm{R}=$<smiles>O=CCc1ccccc1</smiles>

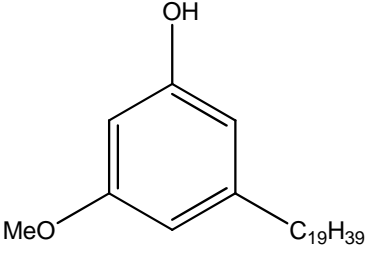

(143)

Table 13. Simple Aryl Ketones.

\begin{tabular}{|l|l|l|l|}
\hline Name & Alternative Name(s) & CAS number & References \\
\hline $\begin{array}{l}\text { 2',4',6'-Trihydroxyacetophenone 2',4'-dimethyl ether } \\
(\mathbf{1 4 4})\end{array}$ & 2-Hydroxy-4,6-dimethoxyacetophenone & {$[68]$} \\
\hline 2',4',6'-Trihydroxyacetophenone 2'-methyl ether (145) & $\begin{array}{l}\text { 2',4'-dihydroxy-6'- } \\
\text { methoxyacetophenone }\end{array}$ & {$[3602-54-8]$} & {$[68,69]$} \\
\hline $\begin{array}{l}\text { 2',4',6'-Trihydroxyacetophenone 2'-methyl ether 4'-O- } \beta- \\
\text { D-glucopyranosde (146) }\end{array}$ & Annphenone & {$[61775-18-6]$} & {$[70]$} \\
\hline $\begin{array}{l}\text { 2',4',6'-Trihydroxyacetophenone 4'-methyl ether 2-O- } \beta- \\
\text { D-glucopyranoside (147) }\end{array}$ & Domesticoside & {$[24587-97-1]$} & {$[15]$} \\
\hline
\end{tabular}<smiles>CCOc1cc(O)c(C(C)=O)c(OCC)c1</smiles>

(144) $\mathrm{R}_{1}=\mathrm{Me} ; \mathrm{R}_{2}=\mathrm{Me}$

(145) $\mathrm{R}_{1}=\mathrm{Me} ; \mathrm{R}_{2}=\mathrm{H}$

(146) $\mathrm{R}_{1}=\mathrm{Me} ; \mathrm{R}_{2}=\mathrm{Glc}$

(147) $\mathrm{R}_{1}=\mathrm{Glc} ; \mathrm{R}_{2}=\mathrm{Me}$

Table 14. Simple Benzoic Acids and their Homologues.

\begin{tabular}{|l|l|l|l|}
\hline Name & Alternative Name(s) & CAS Number & References \\
\hline Benzoic acid (148) & & {$[65-85-0]$} & {$[9,24]$} \\
Salicylic acid (149) & 2-Hydroxybenzoic acid & {$[69-72-7]$} & {$[15]$} \\
Methyl salicylate (150) & Methyl-2-hydroxybenzoate & {$[119-36-8]$} & {$[27,32]$} \\
2-Hydroxybenzoic acid, 3-methylbutyl ester (151) & Isoamyl salicylate & {$[87-20-7]$} & {$[24]$} \\
3,4-Dihydroxybenzoic acid (152) & Benzoic acid, 3,4-dihydroxy- & {$[99-50-3]$} & {$[71]$} \\
Protocatechuic acid 4-glucoside (153) & Protocatechuic acid & {$[7361-59-3]$} \\
Phenylacetic acid (154) & Benzoic acid, 4-( $\beta$-D-glucosyloxy)-3-hydroxy- & {$[103-82-2]$} & {$[24]$} \\
Phenylpropanoic acid (155) & & {$[9]$} \\
Benzenepropanoic acid, 3-cyanophenyl ester (156) & & {$[40123-39-5]$} & {$[50]$} \\
\hline
\end{tabular}<smiles>O=C(O)c1ccccc1</smiles><smiles>[R]Oc1ccccc1O</smiles>

(148)
(149) $\mathrm{R}=\mathrm{H}$

(150) $\mathrm{R}=\mathrm{Me}$

(151)

$\mathrm{R}=\mathrm{CH}_{2} \mathrm{CH}_{2} \mathrm{CH}\left(\mathrm{CH}_{3}\right)_{2}$<smiles>[R20]c1ccc(C(=O)O)cc1O</smiles><smiles>[R]OC(C)(C)C(C)(C)c1ccccc1</smiles>

(152) $\mathrm{R}=\mathrm{H}$

(154) $\mathrm{n}=1 ; \mathrm{R}=\mathrm{H}$

(153) $\mathrm{R}=$ Glc

(155) $\mathrm{n}=2 ; \mathrm{R}=\mathrm{H}$

(156) $n=2$<smiles>Cc1cccc(C#N)c1</smiles> 


\subsection{Phenylpropanoids}

The phenylpropanoids, all of which contain a $\mathrm{C}_{3}$ substituent fused to a benzene ring $\left(\mathrm{C}_{6}\right)$, are produced by the shikimate pathway, which is unique to plants. Most of the simple phenylpropanoids reported in Table 15 were described from GC-MS studies. Compounds 166-182 (Table 16), which are esters formed by various combinations of ferulic and cinnamic acid with the four hydroxyl groups of quinic acid, were isolated from a single HPLC-MS study [71]. Some of the coumarins reported in Table 17 have also been obtained from undifferentiated tissue cultures (callus and suspension) of $A$. annua (see Section 4.2). The structures of both of the 2,2-dihydroxychromene natural products 190 and 191, which appear in Table 17, are questionable on thermodynamic grounds - one might expect both to lose a molecule of water thereby forming a more highly conjugated coumarin.

Table 15. Simple Phenylpropanoids.

\begin{tabular}{|c|c|c|c|}
\hline Name & Alternative Name(s) & CAS Number & References \\
\hline p-Allylanisole (157) & 1-Methoxy-4-(2-propenyl)benzene & {$[140-67-0]$} & {$[29,72,73]$} \\
\hline Anethole (158) & 1-Methoxy-4-(1-propenyl)benzene & {$[4180-23-8]$} & {$[32,43,50]$} \\
\hline 3-Allyl-6-methoxyphenol (159) & 4-Allyl-2-hydroxyl-1-methoxybenzene & {$[501-19-9]$} & {$[48]$} \\
\hline Eugenol (160) & 2-Methoxy-4-(2-propenyl)phenol & {$[97-53-0]$} & {$[19,32,41,43,74]$} \\
\hline Methyl eugenol (161) & 1,2-Dimethoxy-4-(2-propenyl)benzene & {$[93-15-2]$} & {$[43,48]$} \\
\hline Eugenyl isovalerate (162) & 2-Methoxy-4-(2-propenyl)phenol 3-methylbutanoyl & [61114-24-7] & [34] \\
\hline 2-Methoxy-3-(2-propenyl)phenol (163) & & [1941-12-4] & [23] \\
\hline
\end{tabular}

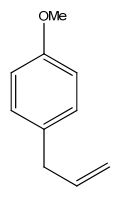

(157)

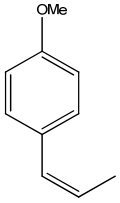

(158)

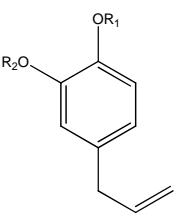

(159) $\mathrm{R}_{1}=\mathrm{Me} ; \mathrm{R}_{2}=\mathrm{H}$

(160) $\mathrm{R}_{1}=\mathrm{OH} ; \mathrm{R}_{2}=\mathrm{Me}$

(161) $\mathrm{R}_{1}=\mathrm{Me} ; \mathrm{R}_{2}=\mathrm{Me}$

(162) $\mathrm{R}_{1}=(\mathrm{C}=\mathrm{O}) \mathrm{CH}_{2} \mathrm{CH}\left(\mathrm{CH}_{3}\right)_{2}$;

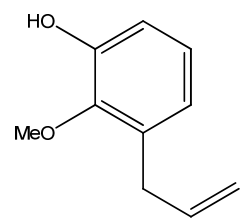

(163)

Table 16. Cinnamyl, Caffeoyl and Ferruloyl esters.

\begin{tabular}{|c|c|c|c|}
\hline Name & Alternative Name(s) & CAS Number & Refs \\
\hline Methyl cinnamate (164) & 3-phenyl-2-propenoic acid methyl ester & {$[103-26-4]$} & {$[24]$} \\
\hline Benzyl cinnamate $(\mathbf{1 6 5})$ & 3-Phenyl-2-propenoic acid benzyl ester & [103-41-3] & {$[24]$} \\
\hline Chlorogenic acid (166) & 3-(3,4-Dihydroxycinnamoyl)quinic acid & [327-97-9] & [71] \\
\hline Cyclohexanecarboxylic acid, 1,3,4-trihydroxy-5-[[3-(4-hydroxy- & & {$[53905-80-9]$} & [71] \\
\hline $\begin{array}{l}\text { 3-methoxyphenyl)-1-oxo-2-propenyl] oxy]-, (167) } \\
\text { Cyclohexanecarboxylic acid, 3-[[3-(3,4-dihydroxyphenyl)-1-oxo- } \\
\text { 2-propenyl] oxy]-1,4,5-trihydroxy-, (168) }\end{array}$ & & {$[342811-68-1]$} & [71] \\
\hline Isochlorogenic acid B (169) & 3,4-Di-O-caffeoylquinic acid & [4534-61-3] & [71] \\
\hline 3-Caffeoyl-4-feruloylquinic acid (170) & 4-O-Feruloyl-5-O-caffeoylquinic acid & [125132-81-2] & [71] \\
\hline 3,4-Diferuoylquinic acid (171) & & [342811-70-5] & [71] \\
\hline Isochlorogenic acid A (172) & 3,5-bis-(3,4-Dihydroxycinnamoyl)quinic acid) & [2450-53-5] & [71] \\
\hline 3-Caffeoyl-5-feruloylquinic acid (173) & & [478156-24-0] & [71] \\
\hline 3-Feruloyl-5-caffeoylquinic acid (174) & & [1039007-73-2] & [71] \\
\hline 3,5-Diferuoylquinic acid (175) & & [333753-65-4] & [71] \\
\hline Isochlorogenic acid C (176) & 4,5-Di-O-caffeoylquinic acid & {$[57378-72-0]$} & [71] \\
\hline 4-Caffeoyl-5-feruloylquinic acid (177) & & [478156-25-1] & [71] \\
\hline 4-Feruloyl-5-caffeoylquinic acid (178) & & [882535-14-0] & [71] \\
\hline 4,5-Diferuoylquinic acid (179) & & [342811-69-2] & [71] \\
\hline $\begin{array}{l}\text { Cyclohexanecarboxylic acid, 3-[[3-(3,4-dihydroxyphenyl)-1-oxo- } \\
\text { 2-propenyl]oxy]-4,5-dihydroxy-1-[[3-(4-hydroxy-3- } \\
\text { methoxyphenyl)-1-oxo-2-propenyl] oxy]-, (180) }\end{array}$ & & {$[865095-58-5]$} & [71] \\
\hline 1-Caffeoyl-5-feruoylquinic acid (181) & & [865095-57-4] & [71] \\
\hline $\begin{array}{l}\text { Cyclohexanecarboxylic acid, 3,4,5-tris[[3-(3,4-dihydroxy } \\
\text { phenyl)-1-oxo-2-propenyl]oxy]-1-hydroxy-(182) }\end{array}$ & & {$[437611-66-0]$} & [71] \\
\hline
\end{tabular}


Table 16. Cont.<smiles>O=C(O)/C=C/c1ccccc1</smiles>

(164) $\mathrm{R}=\mathrm{Me}$ (165) $\mathrm{R}=\left(\mathrm{C}_{6} \mathrm{H}_{5}\right) \mathrm{CH}_{2}$<smiles>[2H]C1(C(=O)O)C[C@H](O)[C@H](O)[C@H](O)C1</smiles><smiles>[TeH][IH+]</smiles><smiles>O=C/C=C/c1ccc(O)c(O)c1</smiles><smiles>[121In][131In]</smiles><smiles>O=C/C=C/c1ccc(O)c(O[O-])c1</smiles>

(166) $\mathrm{R}_{1}=$ Caffeoyl; $\mathrm{R}_{2}=\mathrm{H} ; \mathrm{R}_{3}=\mathrm{H} ; \mathrm{R}_{4}=\mathrm{H}$

(167) $\mathrm{R}_{1}=$ Feruloyl; $\mathrm{R}_{2}=\mathrm{H} ; \mathrm{R}_{3}=\mathrm{H} ; \mathrm{R}_{4}=\mathrm{H}$

(168) $\mathrm{R}_{1}=\mathrm{H} ; \mathrm{R}_{2}=\mathrm{H} ; \mathrm{R}_{3}=$ Caffeoyl; $\mathrm{R}_{4}=\mathrm{H}$

(169) $\mathrm{R}_{1}=$ Caffeoyl; $\mathrm{R}_{2}=$ Caffeoyl; $\mathrm{R}_{3}=\mathrm{H} ; \mathrm{R}_{4}=\mathrm{H}$

(170) $\mathrm{R}_{1}=$ Caffeoyl; $\mathrm{R}_{2}=$ Feruloyl; $\mathrm{R}_{3}=\mathrm{H} ; \mathrm{R}_{4}=\mathrm{H}$

(171) $\mathrm{R}_{1}=$ Feruloyl; $\mathrm{R}_{2}=$ Feruloyl; $\mathrm{R}_{3}=\mathrm{H} ; \mathrm{R}_{4}=\mathrm{H}$

(172) $\mathrm{R}_{1}=$ Caffeoyl; $\mathrm{R}_{2}=\mathrm{H} ; \mathrm{R}_{3}=$ Caffeoyl; $\mathrm{R}_{4}=\mathrm{H}$

(173) $\mathrm{R}_{1}=$ Caffeoyl; $\mathrm{R}_{2}=\mathrm{H} ; \mathrm{R}_{3}=$ Feruloyl; $\mathrm{R}_{4}=\mathrm{H}$

(174) $\mathrm{R}_{1}=$ Feruloyl; $\mathrm{R}_{2}=\mathrm{H} ; \mathrm{R}_{3}=$ Caffeoyl; $\mathrm{R}_{4}=\mathrm{H}$

(175) $\mathrm{R}_{1}=$ Feruloyl; $\mathrm{R}_{2}=\mathrm{H} ; \mathrm{R}_{3}=$ Feruloyl; $\mathrm{R}_{4}=\mathrm{H}$

(176) $\mathrm{R}_{1}=\mathrm{H} ; \mathrm{R}_{2}=$ Caffeoyl; $\mathrm{R}_{3}=$ Caffeoyl; $\mathrm{R}_{4}=\mathrm{H}$

(177) $\mathrm{R}_{1}=\mathrm{H} ; \mathrm{R}_{2}=$ Caffeoyl; $\mathrm{R}_{3}=$ Feruloyl; $\mathrm{R}_{4}=\mathrm{H}$

(178) $\mathrm{R}_{1}=\mathrm{H} ; \mathrm{R}_{2}=$ Feruloyl; $\mathrm{R}_{3}=$ Caffeoyl; $\mathrm{R}_{4}=\mathrm{H}$

(179) $\mathrm{R}_{1}=\mathrm{H} ; \mathrm{R}_{2}=$ Feruloyl; $\mathrm{R}_{3}=$ Feruloyl; $\mathrm{R}_{4}=\mathrm{H}$

(180) $\mathrm{R}_{1}=\mathrm{H} ; \mathrm{R}_{2}=\mathrm{H} ; \mathrm{R}_{3}=$ Caffeoyl 1; $\mathrm{R}_{4}=$ Feruloyl

(181) $\mathrm{R}_{1}=\mathrm{H} ; \mathrm{R}_{2}=\mathrm{H} ; \mathrm{R}_{3}=$ Feruloyl; $\mathrm{R}_{4}=$ Caffeoyl

(182) $\mathrm{R}_{1}=$ Caffeoyl; $\mathrm{R}_{2}=$ Caffeoyl; $\mathrm{R}_{3}=$ Caffeoyl; $\mathrm{R}_{4}=\mathrm{H}$

Table 17. Coumarins (2H-1-Benzopyran-2-one, 9CI).

\begin{tabular}{|c|c|c|c|}
\hline Name & Alternative Name(s) & CAS Number & References \\
\hline Coumarin (183) & 2H-1-Benzopyran-2-one & {$[91-64-5]$} & $\begin{array}{l}{[56,65,68,75-} \\
77,79-80]\end{array}$ \\
\hline Scopoletin (184) & $\begin{array}{l}\text { 7-Hydroxy-6-methoxycoumarin } \\
\text { 7-Hydroxy-6-methoxy-2H-1-benzopyran-2-one }\end{array}$ & {$[92-61-5]$} & {$[77,79,80-87]$} \\
\hline Scoparone (185) & $\begin{array}{l}\text { 6,7-Dimethoxycoumarin } \\
\text { 6,7-Dimethoxy-2H-1-benzopyran-2-one }\end{array}$ & {$[120-08-1]$} & {$[69,88,89]$} \\
\hline Scopolin (186) & $\begin{array}{l}\text { Scopoletin-O- } \beta \text {-D-glucopyranoside } \\
\text { 7-Hydroxy-6-methoxycoumarin- } O \text { - } \beta \text {-D- } \\
\text { glucopyranoside }\end{array}$ & {$[531-44-2]$} & $\begin{array}{l}{[15,71,79,89,} \\
90]\end{array}$ \\
\hline Isofraxidin (187) & 6,8-Dimethoxy-7-hydroxy coumarin & {$[486-21-5]$} & {$[79,86,87,89]$} \\
\hline Tomentin (188) & $\begin{array}{l}\text { 5,6,7-Trihydroxy-2H-1-benzopyran-2-one } 6,7 \text { - } \\
\text { dimethyl ether }\end{array}$ & {$[28449-62-9]$} & [89] \\
\hline $\begin{array}{l}\text { 6,7-Dimethoxydihydrocoumarin } \\
\text { (189) }\end{array}$ & $\begin{array}{l}\text { 2H-1-Benzopyran-2-one,3,4 3,4-Dihydro-6,7- } \\
\text { dimethoxy-coumarin }\end{array}$ & {$[56680-28-5]$} & {$[88]$} \\
\hline 2,2,6-Trihydroxychromene (190) & $2 H$-1-Benzopyran-2,2,6-triol & {$[161585-88-2]$} & [89] \\
\hline $\begin{array}{l}\text { 2,2-Dihydroxy-6-methoxy-2H-1- } \\
\text { benzopyran (191) }\end{array}$ & $\begin{array}{l}\text { 6-Methoxy-2H-1-benzopyran-2,2-diol } \\
2 H \text {-1-Benzopyran-2,2,6-triol 6-methyl ether }\end{array}$ & {$[161585-87-1]$} & [89] \\
\hline
\end{tabular}<smiles>[R9]c1c([2H])c(Br)c2ccc(=O)oc2c1Br</smiles>

(183) $\mathrm{R}_{1}=\mathrm{H} ; \mathrm{R}_{2}=\mathrm{H} ; \mathrm{R}_{3}=\mathrm{H} ; \mathrm{R}_{4}=\mathrm{H}$

(184) $\mathrm{R}_{1}=\mathrm{H} ; \mathrm{R}_{2}=\mathrm{OMe} ; \mathrm{R}_{3}=\mathrm{OH} ; \mathrm{R}_{4}=\mathrm{H}$

(185) $\mathrm{R}_{1}=\mathrm{H} ; \mathrm{R}_{2}=\mathrm{OMe} ; \mathrm{R}_{3}=\mathrm{OMe} ; \mathrm{R}_{4}=\mathrm{H}$

(186) $\mathrm{R}_{1}=\mathrm{H} ; \mathrm{R}_{2}=\mathrm{OMe} ; \mathrm{R}_{3}=\mathrm{OGlc} ; \mathrm{R}_{4}=\mathrm{H}$

(187) $\mathrm{R}_{1}=\mathrm{H} ; \mathrm{R}_{2}=\mathrm{OMe} ; \mathrm{R}_{3}=\mathrm{OH} ; \mathrm{R}_{4}=\mathrm{OMe}$

(188) $\mathrm{R}_{1}=\mathrm{OH} ; \mathrm{R}_{2}=\mathrm{OMe} ; \mathrm{R}_{3}=\mathrm{OMe} ; \mathrm{R}_{4}=\mathrm{H}$<smiles>COc1cc2c(cc1OC)OC(=O)CC2</smiles>

(189)<smiles>Oc1ccc2c(c1)C=CC(O)(O)O2</smiles>

(190) $\mathrm{R}_{1}=\mathrm{H}$

(191) $\mathrm{R}_{1}=\mathrm{Me}$ 


\subsection{Flavonoids}

A. annua L. is a rich source of flavonoids, as are many other members of the Asteraceae family. It has been suggested that some of the more abundant methoxylated flavonoids from A. annua may potentiate the antimalarial activity of artemisinin in crude extracts of this plant. These flavones include: casticin (227), artemetin (228) [91], chrysosplenol D (225) and chrysoplenetin (226) [92] (interstingly, the latter two flavonoids are also reported to potentiate the activity of berberine and norfloxacin against a resistant strain of Staphylococcus aureus). Perhaps for this reason, phytochemical studies have sometimes sought to determine the distribution of bioactive flavonoids (such as chrysoplenetin (226), casticin (227), eupatin (232) and artemetin (228)) in conjunction with that of artemisinin [93].

The flavonoids are produced from the cyclization of a $\mathrm{C}_{15}$ chalcone precursor, which is in turn derived from malonyl coenzyme A and p-coumaryl coenzyme A (see Section 2.3). A biogenetic classification has been adopted in this section. Thus, this large group of flavonoids has been further sub-divided into flavonones (Table 18), which are produced directly by cyclization of this precursor; and flavonols (3-hydroxy-2-phenyl-4H-1-benzopyran-4-ones), which have undergone subsequent oxygenation at the 3-position (Tables 19-22). The flavonols have been further grouped into tetrahydroxyflavonols in Table 19 [many are related to kaempferol (203)]; pentahydroxyflavonols in Table 20 [many are based on quercetin (207)]; hexahydroxyflavonols, based on quercetagetin (221) in Table 21; and miscellaneous hexahydroxyflavonols (Table 22).

Table 18. Flavones (2-Phenyl-4H-1-benzopyran-4-one).

\begin{tabular}{|c|c|c|c|}
\hline Name & Alternative Name(s) & CAS Number & References \\
\hline Apigenin (192) & $\begin{array}{l}\text { 4',5,7-Trihydroxyflavone } \\
\text { 5,7-Dihydroxy-2-(4-hydroxyphenyl)-4H-1-benzopyran-4-one }\end{array}$ & {$[520-36-5]$} & {$[71,89]$} \\
\hline \multicolumn{4}{|l|}{ Luteolin tetrahydroxyflavones } \\
\hline Luteolin (193) & $\begin{array}{l}\text { 3',4',5,7-Tetrahydroxyflavone } \\
\text { 2-(3,4-Dihydroxyphenyl)-5,7,-dihydroxy-4H-1-benzopyran-4-one }\end{array}$ & {$[491-70-3]$} & {$[84,89]$} \\
\hline Luteolin-7-methyl ether (194) & $\begin{array}{l}\text { 3',4',5-Trihydroxy-7-methoxyflavone } \\
\text { 2-(3,4-Dihydroxyphenyl)-5-hydroxy-7-methoxy-4H-1- } \\
\text { benzopyran-4-one }\end{array}$ & [20243-59-8] & [89] \\
\hline Glucoluteolin (195) & $\begin{array}{l}\text { 3,4',5,7-Tetrahydroxyflavone-7-O- } \beta \text {-D-glucopyranoside } \\
\text { Luteolin } 7 \text {-glucoside }\end{array}$ & {$[5373-11-5]$} & {$[84,89]$} \\
\hline Chrysoeriol (196) & $\begin{array}{l}\text { 4',5,7-Trihydroxy-3'-methoxyflavone } \\
\text { 5,7-Dihydroxy-2-(4-hydroxy-3-methoxyphenyl)-4H-1- } \\
\text { benzopyran-4-one }\end{array}$ & [491-71-4] & {$[76,94]$} \\
\hline \multicolumn{4}{|l|}{ Other tetrahydroxyflavones } \\
\hline Cirsimaritin (197) & $\begin{array}{l}\text { 4',5-Dihydroxy-6,7-dimethoxyflavone } \\
\text { 5-Hydroxy-2-(4-hydroxyphenyl)-6,7-dimethoxy-4H-1- } \\
\text { benzopyran-4-one }\end{array}$ & [6601-62-3] & {$[76,94]$} \\
\hline \multicolumn{4}{|l|}{ Pentahydroxyflavones } \\
\hline Cirsiliol (198) & $\begin{array}{l}\text { 3',4',5,6,7-Pentahydroxyflavone 6,7-dimethyl ether } \\
\text { 3',4',5-Trihydroxy-6,7-dimethoxyflavone }\end{array}$ & [34334-69-5] & {$[76,94]$} \\
\hline Eupatorin (199) & $\begin{array}{l}\text { 6-Methoxy luteolin 7,4'-dimethyl ether } \\
\text { 3',5-Dihydroxy-4',6,7-trimethoxyflavone } \\
\text { 5-Hydroxy-2-(3-hydroxy-4-methoxyphenyl)-6,7-dimethoxy-4H- } \\
\text { 1-benzopyran-4-one }\end{array}$ & {$[855-96-9]$} & {$[76,94,95]$} \\
\hline $\begin{array}{l}\text { 5-Hydroxy-3',4',6,7- } \\
\text { tetramethoxyflavone (200) }\end{array}$ & 3',4',5,6,7-Pentahydroxyflavone 3',4',6,7-tetra methyl ether & {$[21763-80-4]$} & {$[96]$} \\
\hline $\begin{array}{l}\text { 4H-1-Benzopyran-4-one, } 2-(2,4- \\
\text { dihydroxyphenyl)-5-hydroxy-6,7- } \\
\text { dimethoxy- (201) }\end{array}$ & & [101909-51-7] & {$[76]$} \\
\hline \multicolumn{4}{|l|}{ Hexahydroxyflavones } \\
\hline $\begin{array}{l}\text { 2,4',5'-Trihydroxy-5'6,7- } \\
\text { trimethoxyflavone }(\mathbf{2 0 2})\end{array}$ & & & {$[94]$} \\
\hline
\end{tabular}


Table 18. Cont.<smiles>O=c1cc(-c2ccc(O)cc2)oc2cc(O)cc(O)c12</smiles>

(192)<smiles>O=c1cc(-c2ccc(O)c(O)c2)oc2cc(O)c(O)c(O)c12</smiles>

(198) $\mathrm{R}_{1}=\mathrm{H} ; \mathrm{R}_{2}=\mathrm{H}$

(199) $\mathrm{R}_{1}=\mathrm{H} ; \mathrm{R}_{2}=\mathrm{Me}$

(200) $\mathrm{R}_{1}=\mathrm{Me} ; \mathrm{R}_{2}=\mathrm{Me}$<smiles>O=c1cc(-c2ccc(O)c(O)c2)oc2cc(O)cc(O)c12</smiles>

(193) $\mathrm{R}_{1}=\mathrm{H} ; \mathrm{R}_{2}=\mathrm{H}$

(194) $\mathrm{R}_{1}=\mathrm{Me} ; \mathrm{R}_{2}=\mathrm{H}$

(195) $\mathrm{R}_{1}=\mathrm{Glc} ; \mathrm{R}_{2}=\mathrm{H}$

(196) $\mathrm{R}_{1}=\mathrm{H} ; \mathrm{R}_{2}=\mathrm{Me}$<smiles>O=c1cc(-c2ccc(O)cc2O)oc2cc(O)c(O)c(O)c12</smiles>

(201)<smiles>O=c1cc(-c2ccc(O)cc2)oc2cc(O)c(O)c(O)c12</smiles>

(197)<smiles>COc1cc(-c2cc(=O)c3c(O)c(O)c(O)cc3o2)c(O)cc1O</smiles>

(202)

Table 19. Tetrahydroxy Flavonols.

\begin{tabular}{|c|c|c|c|}
\hline Name & Alternative Name(s) & $\begin{array}{l}\text { CAS } \\
\text { Number } \\
\end{array}$ & References \\
\hline \multicolumn{4}{|l|}{ Kaempferols } \\
\hline Kaempferol (203) & $\begin{array}{l}\text { 3,4',5,7-Tetrahydroxyflavone } \\
\text { 3,5,7-Trihydroxy-2-(4-hydroxyphenyl)-4H-1- } \\
\text { benzopyran-4-one } \\
\text { 4',5,7-Trihydroxyflavonol }\end{array}$ & [520-18-3] & {$[84,89]$} \\
\hline Kaempferol-3-O-glucoside (204) & $\begin{array}{l}\text { Astragalin } \\
\text { 3-O- } \beta \text {-D-Glucopyranosyloxy- } 4,5,7- \\
\text { trihydroxyflavone }\end{array}$ & {$[480-10-4]$} & {$[84,89]$} \\
\hline Rhamnocitrin (205) & $\begin{array}{l}\text { 3,4',5-Trihydroxy-7-methoxyflavone } \\
\text { 3,5-Dihydroxy-2-(4-hydroxyphenyl)-7-methoxy- } \\
\text { 4H-1-benzopyran-4-one } \\
\text { 4',5-Dihydroxy-7-methoxyflavonol }\end{array}$ & {$[569-92-6]$} & {$[76,94]$} \\
\hline \multicolumn{4}{|l|}{ Other Tetrahydroxyflavonols } \\
\hline $\begin{array}{l}\text { 4H-1-Benzopyran-4-one, 3-hydroxy- } \\
\text { 6,7-dimethoxy-2-(4-methoxyphenyl)- } \\
\text { (206) }\end{array}$ & & [77184-81-7] & [71] \\
\hline
\end{tabular}<smiles>O=c1c(O)c(-c2ccc(O)cc2)oc2cc(O)cc(O)c12</smiles>

(203) $\mathrm{R}_{1}=\mathrm{H} ; \mathrm{R}_{2}=\mathrm{H}$

(204) $\mathrm{R}_{1}=\mathrm{Glc} ; \mathrm{R}_{2}=\mathrm{H}$

(205) $\mathrm{R}_{1}=\mathrm{H} ; \mathrm{R}_{2}=\mathrm{Me}$<smiles>COc1ccc(-c2oc3cc(OC)c(OC)cc3c(=O)c2O)cc1</smiles>

(206) 
Table 20. Pentahydroxy Flavonols.

\begin{tabular}{|c|c|c|c|}
\hline Name & Alternative Name(s) & CAS Number & Refs \\
\hline \multicolumn{4}{|l|}{ Quercetin } \\
\hline Quercetin (207) & $\begin{array}{l}\text { 3,3',4',5,7-Pentahydroxyflavone } \\
\text { 2-(3,4-Dihydroxyphenyl)-3,5,7-trihydroxy-4H-1-benzopyran-4-one } \\
\text { 3',4',5,7-Tetrahydroxyflavonol }\end{array}$ & [117-39-5] & {$[84]$} \\
\hline Quercetin 3-methyl ether (208) & $\begin{array}{l}\text { 3',4',5,7-Tetrahydroxy-3-methoxyflavone } \\
\text { 2-(3,4-Dihydroxyphenyl)-5,7-dihydroxy-3-methoxy-4H-1- } \\
\text { benzopyran-4-one }\end{array}$ & {$[1486-70-0]$} & $\begin{array}{l}{[76,} \\
94]\end{array}$ \\
\hline Isoquercitrin (209) & $\begin{array}{l}\text { Quercetin-3-glucofuranoside } \\
\text { 2-(3,4-Dihydroxyphenyl)-3-( } \beta \text {-D-glucopyranosyloxy)-5,7-dihydroxy- } \\
\text { 4H-1-benzopyran-4-one } \\
\text { 3-Glucopyranosyloxy-3',4',5,7-tetrahydroxyflavone } \\
\text { Quercetin-3-glucopyranoside }\end{array}$ & $\begin{array}{l}{[21637-25-2]} \\
{[482-35-9]}\end{array}$ & $\begin{array}{l}{[71,} \\
89]\end{array}$ \\
\hline Quercetin 3-rutinoside (210) & & [153-18-4] & [84] \\
\hline Isorhamnetin 3-glucoside (211) & 3-Glucopyranosyloxy-4',5,7-trihydroxy-3'-methoxyflavone & [5041-82-7] & {$[71]$} \\
\hline Rhamnetin (212) & $\begin{array}{l}\text { 3,3',4',5-Tetrahydroxy-7-methoxyflavone } \\
\text { 2-(3,4-Dihydroxyphenyl)-3,5-dihydroxy-7-methoxy-4H-1- } \\
\text { benzopyran-4-one } \\
\text { 3',4'5-Trihydroxy-7-methoxyflavonol }\end{array}$ & {$[90-19-7]$} & 946 \\
\hline Quercimeritrin (213) & $\begin{array}{l}\text { 7-O- } \beta \text {-D-glucopyranosyloxy-3,3',4',5-tetrahydroxyflavone } \\
\text { Quercetin 7-glucoside }\end{array}$ & [491-50-9] & [89] \\
\hline Isorhamnetin (214) & $\begin{array}{l}\text { 3,4',5,7-Tetrahydroxy-3'-methoxyflavone } \\
\text { 3,5,7-Trihydroxy-2-(4-hydroxy-3-methoxyphenyl)-4H-1-benzopyran- } \\
\text { 4-one } \\
\text { 4',5,7-Trihydroxy-3'-methoxyflavonol } \\
\text { Quercetin 3'-methyl ether }\end{array}$ & {$[480-19-3]$} & [89] \\
\hline Quercetin 3'-glucoside (215) & 3,3,'4',5,7-Pentahydroxyflavone 3'-O- $\beta$-D-glucopyranoside & [19254-30-9] & $\begin{array}{l}{[84,} \\
89]\end{array}$ \\
\hline Tamarixetin (216) & $\begin{array}{l}\text { 3,3',5,7-Tetrahydroxy-4'-methoxyflavone } \\
\text { 3,5,7-Trihydroxy-2-(3-hydroxy-4-methoxyphenyl)-4H-1-benzopyran- } \\
\text { 4-one } \\
\text { 3',5,7-Trihydroxy-4'-methoxyflavonol }\end{array}$ & {$[603-61-2]$} & $\begin{array}{l}{[76,} \\
94]\end{array}$ \\
\hline \multicolumn{4}{|l|}{ Other pentahydroxyflavonols } \\
\hline Eupalitin (217) & $\begin{array}{l}\text { 3,4',5-Trihydroxy-6,7-dimethoxyflavone } \\
\text { 3,5-Dihydroxy-2-(4-hydroxyphenyl)-6,7-dimethoxy-4H-1-benzopyran- } \\
\text { 4-one } \\
\text { 4',5-Dihydroxy-6,7-dimethoxyflavonol }\end{array}$ & [29536-41-2] & [96] \\
\hline Penduletin (218) & $\begin{array}{l}\text { 3,4',5,6,7-Pentahydroxyflavone 3,6,7-trimethyl ether } \\
\text { 4',5-Dihydroxy-3,6,7-trimethoxyflavone }\end{array}$ & {$[569-80-2]$} & $\begin{array}{l}{[76,94,} \\
97]\end{array}$ \\
\hline $\begin{array}{l}\text { 3,4',5,6,7-Pentahydroxyflavone } \\
3,4^{\prime}, 6,7 \text {-tetramethyl ether } \\
(\mathbf{2 1 9})\end{array}$ & 5-Hydroxy-3,4',6,7-tetramethoxyflavone & [14787-34-9] & $\begin{array}{l}{[61,75,} \\
78,97]\end{array}$ \\
\hline Mikanin (220) & $\begin{array}{l}\text { 3,4',5,6,7-Pentahydroxyflavone 4',6,7-trimethyl ether } \\
\text { 3,5-Dihydroxy-4',6,7-trimethoxyflavone }\end{array}$ & [4324-53-2] & {$[71]$} \\
\hline
\end{tabular}<smiles></smiles>

(207) $\mathrm{R}_{1}=\mathrm{H} ; \mathrm{R}_{2}=\mathrm{H} ; \mathrm{R}_{3}=\mathrm{H} ; \mathrm{R}_{4}=\mathrm{H}$

(212) $\mathrm{R}_{1}=\mathrm{H} ; \mathrm{R}_{2}=\mathrm{Me} ; \mathrm{R}_{3}=\mathrm{H} ; \mathrm{R}_{4}=\mathrm{H}$

(208) $\mathrm{R}_{1}=\mathrm{Me} ; \mathrm{R}_{2}=\mathrm{H} ; \mathrm{R}_{3}=\mathrm{H} ; \mathrm{R}_{4}=\mathrm{H}$

(213) $\mathrm{R}_{1}=\mathrm{H} ; \mathrm{R}_{2}=\mathrm{Glc} ; \mathrm{R}_{3}=\mathrm{H} ; \mathrm{R}_{4}=\mathrm{H}$

(209) $\mathrm{R}_{1}=\mathrm{Glc} ; \mathrm{R}_{2}=\mathrm{H} ; \mathrm{R}_{3}=\mathrm{H} ; \mathrm{R}_{4}=\mathrm{H}$

(214) $\mathrm{R}_{1}=\mathrm{H} ; \mathrm{R}_{2}=\mathrm{H} ; \mathrm{R}_{3}=\mathrm{Me} ; \mathrm{R}_{4}=\mathrm{H}$

(210) $\mathrm{R}_{1}=$ Sugar; $\mathrm{R}_{2}=\mathrm{H} ; \mathrm{R}_{3}=\mathrm{H} ; \mathrm{R}_{4}=\mathrm{H}$ (215) $\mathrm{R}_{1}=\mathrm{H} ; \mathrm{R}_{2}=\mathrm{H} ; \mathrm{R}_{3}=\mathrm{Glc} ; \mathrm{R}_{4}=\mathrm{H}$

(211) $\mathrm{R}_{1}=\mathrm{Glc} ; \mathrm{R}_{2}=\mathrm{H} ; \mathrm{R}_{3}=\mathrm{Me} ; \mathrm{R}_{4}=\mathrm{H}$ (216) $\mathrm{R}_{1}=\mathrm{H} ; \mathrm{R}_{2}=\mathrm{H} ; \mathrm{R}_{3}=\mathrm{H} ; \mathrm{R}_{4}=\mathrm{Me}$<smiles>COc1cc2oc(-c3ccc(C)cc3)c(O)c(=O)c2c(O)c1OC</smiles>

(217) $\mathrm{R}_{1}=\mathrm{H} ; \mathrm{R}_{2}=\mathrm{H} ; \mathrm{R}_{3}=\mathrm{H}$

(218) $\mathrm{R}_{1}=\mathrm{Me} ; \mathrm{R}_{2}=\mathrm{H} ; \mathrm{R}_{3}=\mathrm{H}$

(219) $\mathrm{R}_{1}=\mathrm{Me} ; \mathrm{R}_{2}=\mathrm{H} ; \mathrm{R}_{3}=\mathrm{Me}$

(220) $\mathrm{R}_{1}=\mathrm{H} ; \mathrm{R}_{2}=\mathrm{H} ; \mathrm{R}_{3}=\mathrm{Me}$ 
Table 21. Quecetagetin (Hexahydroxy) Flavonols.

\begin{tabular}{|c|c|c|c|}
\hline Name & Alternative Name(s) & $\begin{array}{l}\text { CAS } \\
\text { Number }\end{array}$ & References \\
\hline $\begin{array}{l}\text { Quercetagetin 3-methyl } \\
\text { ether (221) }\end{array}$ & $\begin{array}{l}\text { 3',4',5,6,7-Pentahydroxy-3-methoxyflavone } \\
\text { 2-(3,4-Dihydroxyphenyl)-5,6,7-trihydroxy-3-methoxy-4H-1- } \\
\text { benzopyran-4-one }\end{array}$ & [64190-88-1] & [89] \\
\hline Axillarin (222) & $\begin{array}{l}\text { Quercetagetin 3,6-dimethyl ether } \\
\text { 3',4',5,7-Tetrahydroxy-3,6-dimethoxyflavone } \\
\text { 2-(3,4-Dihydroxyphenyl)-5,7-dihydroxy-3,6-dimethoxy-4H-1- } \\
\text { benzopyran-4-one }\end{array}$ & {$[5188-73-8]$} & {$[76,84]$} \\
\hline $\begin{array}{l}\text { Quercetagetin-3,4'- } \\
\text { dimethyl ether (223) }\end{array}$ & $\begin{array}{l}\text { 3',5,6,7-Tetrahydroxy-3,4'-dimethoxyflavone } \\
3,3^{\prime}, 4 \text { ',5,6,7-Hexahydroflavone 3,4'-di-methyl ether }\end{array}$ & [59171-34-5] & {$[76]$} \\
\hline Bonanzin (224) & $\begin{array}{l}\text { 5,7-Dihydroxy-3,3',4',6-tetramethoxyflavone } \\
\text { 2-(3,4-Dimethoxyphenyl)-5,7-dihydroxy-3,6-dimethoxy-4H-1- } \\
\text { benzopran-4-one }\end{array}$ & [35688-42-7] & {$[96]$} \\
\hline Chrysosplenol D (225) & $\begin{array}{l}\text { 2-(3,4-Dihydroxyphenyl)-5-hydroxy-3,6,7-trimethoxy-4H-1- } \\
\text { benzopyran-4-one }\end{array}$ & [14965-20-9] & $\begin{array}{l}{[15,76,84} \\
92,94,95,98]\end{array}$ \\
\hline Chrysosplenetin (226) & $\begin{array}{l}\text { Chrysosplenol B } \\
\text { 5,4'-Dihydroxy-3,6,7,3'-tetramethoxyflavone } \\
\text { 5-Hydroxy-2-(4-hydroxy-3-methoxyphenyl)-3,6,7-trimethoxy- } \\
\text { 4H-1-benzopyran-4-one }\end{array}$ & {$[603-56-5]$} & $\begin{array}{l}{[15,76,80} \\
84,91,92,95 \\
96,99-101]\end{array}$ \\
\hline Casticin (227) & $\begin{array}{l}\text { Quercetagetin 6,3,7,4'-tetramethyl ether } \\
\text { 3',5-Dihydroxy-3,4',6,7-tetramethoxyflavone } \\
\text { 5-Hydroxy-2-(3-hydroxy-4-methoxyphenyl)-3,6,7-trimethoxy- } \\
\text { 4H-benzopyran-4-one }\end{array}$ & [479-91-4] & $\begin{array}{l}{[76,84,91} \\
94,95,98,99 \\
100,103]\end{array}$ \\
\hline Artemetin (228) & $\begin{array}{l}\text { 5-Hydroxy-3,6,7,3',4'-Pentamethoxyflavone } \\
\text { 2-(3,4,-Dimethoxyphenyl)-5-hydroxy-3,6,7-trimethoxy-4H-1- } \\
\text { benzopyran-4-one }\end{array}$ & {$[479-90-3]$} & $\begin{array}{l}{[15,75,77,} \\
78,80,94,95 \\
96,98,100 \\
105,106]\end{array}$ \\
\hline $\begin{array}{l}\text { Patuletin-3-O-glucoside } \\
\text { (229) }\end{array}$ & $\begin{array}{l}\text { Quercetagetin 6-methyl ether 3-O-glucoside } \\
\text { 6-Methoxykaempferol -3-O-glucoside }\end{array}$ & [19833-27-3] & {$[84]$} \\
\hline Patuletin (230) & $\begin{array}{l}\text { 3,3',4',5,7-Pentahydroxy-6-methoxyflavone } \\
\text { 2-(3,4-Dihydroxyphenyl)-3,5,7-trihydroxy-6-methoxy-4H-1- } \\
\text { benzopyran-4-one } \\
\text { 3',4',5,7-Tetrahydroxy-6-methoxyflavonol }\end{array}$ & [519-96-0] & {$[84]$} \\
\hline Cirsilineol (231) & $\begin{array}{l}\text { 3',4',5,6,7-Pentahydroxyflavone 3',6,7-tri methyl ether } \\
\text { 4',5-Dihydroxy-3',6,7-trimethoxyflavone }\end{array}$ & [41365-32-6] & $\begin{array}{l}{[76,94,95,} \\
98]\end{array}$ \\
\hline Eupatin (232) & $\begin{array}{l}\text { 3,3',5-Trihydroxy-4',6,7-trimethoxyflavone } \\
\text { 3,5-Dihydroxy-2-(3-hydroxy-4-methoxyphenyl)-6,7-dimethoxy- } \\
\text { 4H-1-benzopyran-4-one } \\
\text { 3',5-Dihyhdroxy-4',6,7-trimethoxyflavonol } \\
\text { Quercetagetin 4',6,7-trimethyl ether }\end{array}$ & [19587-65-6] & {$[61,77,98]$} \\
\hline $\begin{array}{l}\text { Quercetagetin-6,7,3',4'- } \\
\text { tetramethylether } \\
(\mathbf{2 3 3})\end{array}$ & $\begin{array}{l}\text { 3,5-Dihydroxy-3',4',6,7-tetramethoxyflavone } \\
\text { 3,3',4',5,6,7-Hexahydroflavone 3',4',6,7-tetra methyl ether }\end{array}$ & $\begin{array}{l}{[57296-14-} \\
7]\end{array}$ & $\begin{array}{l}{[61,71,77,} \\
105,107]\end{array}$ \\
\hline $\begin{array}{l}\text { Quercetagetin } \quad 4 \text { '-methyl } \\
\text { ether (234) }\end{array}$ & $\begin{array}{l}\text { 3,3',4',5,6,7-Hexahydroxyflavone 4'-methyl ether } \\
\text { 3,3',5,6,7-Pentahydroxy-4'-methoxyflavone } \\
\text { 3',5,6,7-Tetrahydroxy-4'-methoxyflavonol }\end{array}$ & $\begin{array}{l}{[161585-86-} \\
0]\end{array}$ & [89] \\
\hline
\end{tabular}<smiles></smiles>

(221) $\mathrm{R}_{1}=\mathrm{Me} ; \mathrm{R}_{2}=\mathrm{H} ; \mathrm{R}_{3}=\mathrm{H} ; \mathrm{R}_{4}=\mathrm{H} ; \mathrm{R}_{5}=\mathrm{H}$

(222) $\mathrm{R}_{1}=\mathrm{Me} ; \mathrm{R}_{2}=\mathrm{Me} ; \mathrm{R}_{3}=\mathrm{H} ; \mathrm{R}_{4}=\mathrm{H} ; \mathrm{R}_{5}=\mathrm{H}$

(223) $\mathrm{R}_{1}=\mathrm{Me} ; \mathrm{R}_{2}=\mathrm{H} ; \mathrm{R}_{3}=\mathrm{H} ; \mathrm{R}_{4}=\mathrm{H} ; \mathrm{R}_{5}=\mathrm{Me}$

(224) $\mathrm{R}_{1}=\mathrm{Me} ; \mathrm{R}_{2}=\mathrm{Me} ; \mathrm{R}_{3}=\mathrm{H} ; \mathrm{R}_{4}=\mathrm{Me} ; \mathrm{R}_{5}=\mathrm{Me}$

(225) $\mathrm{R}_{1}=\mathrm{Me} ; \mathrm{R}_{2}=\mathrm{Me} ; \mathrm{R}_{3}=\mathrm{Me} ; \mathrm{R}_{4}=\mathrm{H} ; \mathrm{R}_{5}=\mathrm{H}$

(226) $\mathrm{R}_{1}=\mathrm{Me} ; \mathrm{R}_{2}=\mathrm{Me} ; \mathrm{R}_{3}=\mathrm{Me} ; \mathrm{R}_{4}=\mathrm{Me} ; \mathrm{R}_{5}=\mathrm{H}$

(227) $\mathrm{R}_{1}=\mathrm{Me} ; \mathrm{R}_{2}=\mathrm{Me} ; \mathrm{R}_{3}=\mathrm{Me} ; \mathrm{R}_{4}=\mathrm{H} ; \mathrm{R}_{5}=\mathrm{Me}$
(228) $\mathrm{R}_{1}=\mathrm{Me} ; \mathrm{R}_{2}=\mathrm{Me} ; \mathrm{R}_{3}=\mathrm{Me} ; \mathrm{R}_{4}=\mathrm{Me} ; \mathrm{R}_{5}=\mathrm{Me}$

(229) $\mathrm{R}_{1}=$ Glc; $\mathrm{R}_{2}=\mathrm{Me} ; \mathrm{R}_{3}=\mathrm{H} ; \mathrm{R}_{4}=\mathrm{H} ; \mathrm{R}_{5}=\mathrm{H}$

(230) $\mathrm{R}_{1}=\mathrm{H} ; \mathrm{R}_{2}=\mathrm{Me} ; \mathrm{R}_{3}=\mathrm{H} ; \mathrm{R}_{4}=\mathrm{H} ; \mathrm{R}_{5}=\mathrm{H}$

(231) $\mathrm{R}_{1}=\mathrm{H} ; \mathrm{R}_{2}=\mathrm{Me} ; \mathrm{R}_{3}=\mathrm{Me} ; \mathrm{R}_{4}=\mathrm{Me} ; \mathrm{R}_{5}=\mathrm{H}$

(232) $\mathrm{R}_{1}=\mathrm{H} ; \mathrm{R}_{2}=\mathrm{Me} ; \mathrm{R}_{3}=\mathrm{Me} ; \mathrm{R}_{4}=\mathrm{H} ; \mathrm{R}_{5}=\mathrm{Me}$

(233) $\mathrm{R}_{1}=\mathrm{H} ; \mathrm{R}_{2}=\mathrm{Me} ; \mathrm{R}_{3}=\mathrm{Me} ; \mathrm{R}_{4}=\mathrm{Me} ; \mathrm{R}_{5}=\mathrm{Me}$

(234) $\mathrm{R}_{1}=\mathrm{H} ; \mathrm{R}_{2}=\mathrm{H} ; \mathrm{R}_{3}=\mathrm{H} ; \mathrm{R}_{4}=\mathrm{H} ; \mathrm{R}_{5}=\mathrm{Me}$ 
Table 22. Other Hexahydroxy Flavonols.

\begin{tabular}{|c|c|c|c|}
\hline Name & Alternative Name(s) & CAS Number & References \\
\hline $\begin{array}{l}\text { 4H-1-Benzopyran-4-one 5-hydroxy-2-(2-hydroxy-3,4- } \\
\text { di-methoxyphenyl)-3,7-dimethoxy (235) }\end{array}$ & & {$[1186306-45-5]$} & {$[15]$} \\
\hline $\begin{array}{l}\text { 4H-1-Benzopyran-4-one, 2-(3,5-dihydroxy-4-methoxy- } \\
\text { phenyl)-3-( } \beta \text {-D-glucopyranosyloxy)-5,7-dihydroxy- } \\
\text { (236) }\end{array}$ & & {$[230283-37-1]$} & [71] \\
\hline Mearnsetin (237) & $\begin{array}{l}\text { 3,3',5,5',7-Pentahydroxy-4'-methoxy- } \\
\text { flavone } \\
\text { 2-(3,5-Dihydroxyphenyl-4-methoxy- } \\
\text { phenol)-3,5,7-trihydroxy-4H-1- } \\
\text { benzopyran-4-one } \\
\text { 3',5',5',7-Tetrahydroxy-4'-methoxy- } \\
\text { flavonol }\end{array}$ & [16805-10-0] & {$[71]$} \\
\hline Chrysosplenol E (238) & $\begin{array}{l}\text { 2',3,4',5,5',7-Hexahydroxyflavone } \\
\text { 3,4',5',7-tetramethyl ether } \\
\text { 2',5-Dihydroxy-3,4',5',7-tetramethoxy- } \\
\text { flavone }\end{array}$ & [23289-81-8] & [80] \\
\hline 5,3'-Dihydroxy, 3,6,7,5'-tetramethoxyflavone (239) & & & [99] \\
\hline 3',5,7,8-Tetrahydroxy-3,4'-dimethoxyflavone (240) & $\begin{array}{l}3,3^{\prime}, 4^{\prime}, 5,7,8 \text {-Hexahydroxyflavone } 3,4^{\prime} \text { 'di- } \\
\text { ethyl ether }\end{array}$ & {$[123563-74-6]$} & {$[76,94]$} \\
\hline
\end{tabular}<smiles>COc1cc(O)c2c(=O)c(O)c(-c3ccc(O)c(OC)c3O)oc2c1</smiles>

(235)<smiles>COc1cc(O)c2c(=O)c(O)c(-c3cc(O)c(O)c(O)c3)oc2c1</smiles>

(236) $\mathrm{R}_{1}=\mathrm{Glc} ; \mathrm{R}_{2}=\mathrm{H}$

(237) $\mathrm{R}_{1}=\mathrm{H} ; \mathrm{R}_{2}=\mathrm{H}$<smiles>COc1cc2c(cc1O)-c1oc3cc(O)cc(O)c3c(=O)c1ON2</smiles>

(238)<smiles>COc1cc(O)cc(-c2oc3cc(O)c(O)c(O)c3c(=O)c2O)c1</smiles>

(239)<smiles>COc1ccc(-c2oc3c(O)c(O)cc(O)c3c(=O)c2O)cc1O</smiles>

(240)

The miscellaneous polycyclic aromatic natural product acenaphthylene, 1,2,4,5-tetrahydro([54271-92-0]) (241) is also reported from A. annua [34].<smiles>c1cc2c3c(cccc3c1)CC2</smiles>

(241)

\subsection{Monoterpenoids}

Monoterpenoids generally contain ten carbons $\left(\mathrm{C}_{10}\right)$ and are the principal components of the essential oil of $A$. annua obtained by steam distillation (or other techniques that are selective for more volatile natural products). It is widely believed that monoterpenes are located in the glandular trichomes - small structures, which are loosely attached to the surfaces of the leaves and flowers [108]. 
The regular acyclic monoterpenes which are described in Section 2.5.1 consist of an eight-carbon chain, which is often functionalized at the 1-position, with methyl substituents at the 3-and 7-positions (Table 23). They are formed by ionization of the pyrophosphate group in one of the $\mathrm{C}_{10}$ precursors: geranyl pyrophosphate (GPP), neryl pyrophosphate (NPP) or linalyl pyrophosphate (LPP) (Figure 2) [these monoterpene precursors are, in turn, formed from the "head-to-tail" condensation of a "starter" molecule of dimetylallypyrophosphate (DMAPP) with a "chain extender" of isopentenyl pyrophosphate (IPP) (both $\mathrm{C}_{5}$ )]. A. annua is also a rich source of irregular acyclic monoterpenoids (Section 2.5.2), which are derived from the "head-to-middle" condensation of two $\mathrm{C}_{5}$ precursors.

Figure 2. Structures of isopentenyl pyrophosphate (IPP), dimethylallyl pyrophosphate (DMAPP), geranyl pyrophosphate (GPP), neryl pyrophosphate (NPP) and linaloyl pyrophosphate (LPP) which are all possible precursors to monoterpenes from A.annua.

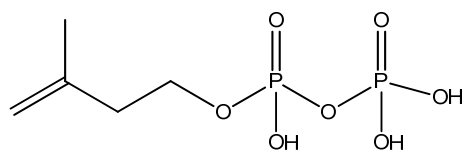

IPP<smiles>CC(C)=CCC/C(C)=C/COP(=O)(O)OP(=O)(O)O</smiles><smiles>CC(C)=CCOP(=O)(O)OP(=O)(O)O</smiles>

DMAPP

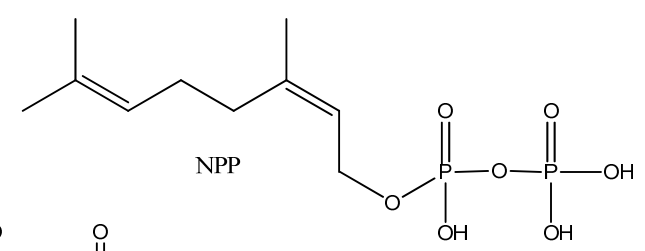

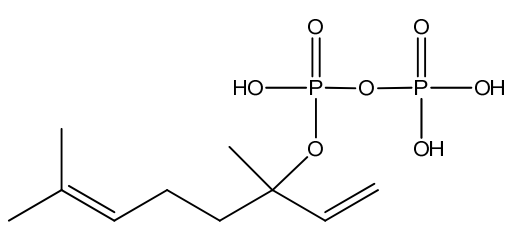

LPP

The "regular" acyclic monoterpenoid precursors can then undergo further intramolecular reactions to yield monocyclic monoterpenes (Section 2.5.3). The largest group of such monocyclic monoterpenes in A. annua is the p-menthane series (Table 25), which incorporate a single sixmembered ring. Further cyclization produces bicyclic monoterpenes (Section 2.5.4), which may contain an additional five-membered ring (e.g., camphanes in Table 26); or a four-membered ring (pinanes, Table 27); or a three-membered ring (thujanes, Table 28). Studies with ${ }^{14} \mathrm{C}$-labeled LPP have shown that in A. annua this precursor is converted to cyclised monoterpenes such as 1,8 -cineole (326) and $\alpha$-pinene (347) with greater efficiency than the alternative precusors, NPP and GPP [109].

\subsubsection{Regular Acyclic Monoterpenes}

A cDNA for (3R)-linalool synthase, which converts GPP to (3R)-linalool (250) by ionization of the pyrophosphate group, has been described recently from A. annua [110]. Most of the regular acyclic monoterpenes reported in Table 23 can be derived by further functional group modifications (dehydration, reduction or oxidation) of linalool (250) or its isomers, geraniol (244) and nerol (248). 
Table 23. Regular Acyclic Monoterpenoids (2,6-Dimethyloctane, 9CI, 8CI).

\begin{tabular}{|c|c|c|c|}
\hline Name & Alternative Name(s) & CAS number & References \\
\hline Citronellol (242) & 3,7-Dimethyl-6-octen-1-ol & {$[106-22-9]$} & {$[24]$} \\
\hline Citronellal (243) & 3,7-Dimethyl-6-octenal & [106-23-0] & [28] \\
\hline Geraniol (244) & (E)-3,7-Dimethyl-2,6-octadien-1-ol & {$[106-24-1]$} & [22] \\
\hline Geranyl acetate $(\mathbf{2 4 5})$ & (E)-3,7-Dimethyl-2,6-octadien-1-ol acetate & {$[105-87-3]$} & {$[23,51]$} \\
\hline $\begin{array}{l}\text { 3,7-Dimethyl-2,6-octadienyl, isobutyric } \\
\text { acid, ester (246) }\end{array}$ & $\begin{array}{l}\text { (E)-Isobutyric acid, 3,7-dimethyl-2,6-octadienyl } \\
\text { ester }\end{array}$ & [1188-06-3] & {$[50]$} \\
\hline $\begin{array}{l}\text { 2,6-Octadien-1-ol, 2,6-dimethyl-8- } \\
\text { [(tetrahydro-2H-pyran-2-yl)oxy]- (247) }\end{array}$ & & [80444-67-3] & {$[23]$} \\
\hline Nerol (248) & (Z)-3,7-Dimethyl-2,6-octadien-1-ol & {$[106-25-2]$} & {$[23,58]$} \\
\hline Neryl acetate (249) & (Z)-3,7-Dimethyl-2,6-octadien-1-ol acetate & {$[141-12-8]$} & {$[45]$} \\
\hline Linalool (250) & 3,7-Dimethyl-1,6-octadien-3-ol & {$[78-70-6]$} & $\begin{array}{r}{[19,28,31,32} \\
45,51,74,111]\end{array}$ \\
\hline Linalyl acetate $(\mathbf{2 5 1})$ & 3,7-Dimethyl-1,6-octadien-3-ol acetate & {$[115-95-7]$} & {$[32,43]$} \\
\hline 3,7-Octadien-2-ol, 2,6-dimethyl- (252) & & {$[62911-76-6]$} & [23] \\
\hline Myrcenol (253) & 2-Methyl-6-methylene-7-octen-2-ol & {$[543-39-5]$} & {$[30]$} \\
\hline Myrcene (254) & 7-Methyl-3-methylene-1,6-octadiene & {$[123-35-3]$} & $\begin{array}{l}{[19,23,29,32,} \\
33,34,43,45, \\
50,51,73,112, \\
113]\end{array}$ \\
\hline Ipsdienol (255) & 2-Methyl-6-methylene-2,7-octadien-4-ol & {$[35628-00-3]$} & {$[28]$} \\
\hline allo-Ocimene (256) & 2,6-Dimethyl-2,4,6-octatriene & {$[673-84-7]$} & [22] \\
\hline trans- $\alpha$-Ocimene (257) & 3,7-Dimethyl-1,3,7-Octatriene & $\begin{array}{l}{[27400-72-2]} \\
{[3779-61-1]}\end{array}$ & {$[22,32,111]$} \\
\hline (E)- 3,7-Dimethyl-1,3,6-octatriene (258) & & [3779-61-1] & [43] \\
\hline (Z)-3,7-Dimethyl-1,3,6-octatriene (259) & & {$[3338-55-4]$} & {$[32,43]$} \\
\hline 2,6-Dimethyl-3,5,7-octatrien-2-ol (260) & & {$[103272-78-2]$} & {$[23]$} \\
\hline 3,7-Dimethyl-1,5,7-octatrien-3-ol (261) & & {$[29957-43-5]$} & [48] \\
\hline 2,6-Dimethyl-1,5,7-octatrien-3-ol (262) & & [29414-56-0] & [23] \\
\hline $\begin{array}{l}\text { 3,7-Octadien-2-ol, 2-methyl-6-methylene } \\
\text { (263) }\end{array}$ & & {$[22459-09-2]$} & {$[31]$} \\
\hline$\beta$-myrcene hydroperoxide (264) & $\begin{array}{l}\text { 2-Methyl-6-methylene-3,7-octadiene-2-ol }(E), 2- \\
\text { hydroperoxide }\end{array}$ & & {$[9,114]$} \\
\hline$\alpha$ - myrcene hydroperoxide (265) & $\begin{array}{l}\text { 2-Methyl-6-methylene-1,7-octadiene, 3-hydro- } \\
\text { peroxide }\end{array}$ & & {$[9,114]$} \\
\hline $\begin{array}{l}\text { 1,6-Octadien-4-one, 7-methyl-3- } \\
\text { methylene- (266) }\end{array}$ & & $\begin{array}{l}{[1079223-79-} \\
2]\end{array}$ & {$[43]$} \\
\hline $\begin{array}{l}\text { 1,7-Octadien-3-one, 2-methyl-6- } \\
\text { methylene- (267) }\end{array}$ & 2-Methyl-6-methylene-1,7-octadien-3-one & {$[41702-60-7]$} & {$[20]$} \\
\hline cis-Epoxyocimene (268) & 3,7-Dimethyl-1,3,6-Octatriene 6R,7-epoxide & {$[255832-06-5]$} & \\
\hline 2,6-Dimethyl-1,3,5,7-octatetraene (269) & & {$[90973-78-7]$} & {$[50]$} \\
\hline Perillene (270) & 3-(4-Methyl-3-pentenyl)furan & {$[539-52-6]$} & {$[23,43]$} \\
\hline 1,10-Oxy- $\alpha$-myrcene hydroxide (271) & & & [9] \\
\hline 1,10 -Oxy- $\beta$-myrcene hydroxide (272) & & & [9] \\
\hline
\end{tabular}<smiles>CC(C)=CCCC(C)CCO</smiles>

(242)<smiles>[R]C/C(C)=C/CC/C(C)=C/CO</smiles>

(244) $\mathrm{R}_{1}=\mathrm{H} ; \mathrm{R}_{2}=\mathrm{H}$

(245) $\mathrm{R}_{1}=(\mathrm{C}=\mathrm{O}) \mathrm{CH}_{3} ; \mathrm{R}_{2}=\mathrm{H}$

(246) $\mathrm{R}_{1}=(\mathrm{C}=\mathrm{O}) \mathrm{CH}\left(\mathrm{CH}_{3}\right)_{2} ; \mathrm{R}_{2}=\mathrm{H}$<smiles>CC(C)=CCC/C(C)=C/CO</smiles><smiles>CC(C)=CCC[C@H](C)CC=O</smiles>

(243)<smiles>CCC1CCCCO1</smiles>

(247)<smiles>[R]O</smiles><smiles>C=CC(C)(O)CCC=C(C)C</smiles> 
Table 23. Cont.

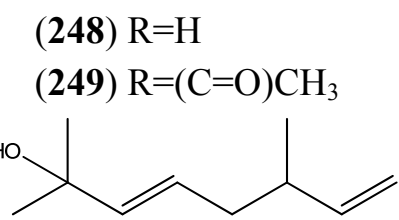

(252)<smiles>[R9]C(C=C(C)C)CC(=C)C=C</smiles>

(254) $\mathrm{R}=\mathrm{H}$

(255) $\mathrm{R}=\mathrm{OH}$<smiles>C=C/C(C)=C/CCC(=C)C</smiles>

(257)<smiles>C=CC(C)=CCC=C(C)C</smiles>

(259)<smiles>C=CC(C)(O)CC=CC(=C)C</smiles>

(261)<smiles>C=CC(=C)C/C=C/C(C)(C)O</smiles>

(263) $\mathrm{R}=\mathrm{H}($ 264) $\mathrm{R}=\mathrm{OH}$<smiles>C=CC(=C)C(=O)CC=C(C)C</smiles>

(266)<smiles>C=C/C(C)=C/CC1OC1(C)C</smiles>

(268)<smiles>CC(C)=CCCc1ccoc1</smiles>

(250) $\mathrm{R}=\mathrm{H}$

(251) $\mathrm{R}=(\mathrm{C}=\mathrm{O}) \mathrm{CH}_{3}$<smiles>C=CC(=C)CCCC(C)(C)O</smiles>

(253)<smiles>CC=C(C)C=CC=C(C)C</smiles>

(256)<smiles>C=C/C(C)=C/CC=C(C)C</smiles>

(258)<smiles>C=C/C(C)=C/C=C/C(C)(C)O</smiles>

(260)<smiles>C=CC(C)=CCC(O)C(=C)C</smiles>

(262)<smiles>C=CC(=C)CCC(O)C(=C)C</smiles>

(265)<smiles>C=CC(=C)CCC(=O)C(=C)C</smiles>

(267)<smiles>C=C/C(C)=C/C=C/C(=C)C</smiles>

(269)<smiles>C=C(C)C(O)CCC1=CCOC1</smiles>

(271)<smiles>CC(C)(O)C=CCC1=CCOC1</smiles>

(272)

Myrcene (254) is the most abundant regular acyclic monoterpene from A. annua, and can account for up to $5 \%$ of the essential oil $[22,33,43]$. The secondary and tertiary allylic hydroperoxides, $\alpha$ - and $\beta$-myrcene hydroperoxide (265 and 264), have been isolated from $A$. annua on more than one occasion $[9,114]$, and are possibly formed by an "ene"-type reaction of molecular oxygen with the tri- 
substituted double bond in myrcene (254), occurring in the presence of light and a photosensitizer (i.e. singlet oxygen, ${ }^{1} \mathrm{O}_{2}$ ), as is shown in Scheme 1. Further known reactions of these allylic hydroperoxides might account for the formation of other highly oxygenated myrcene monoterpenoids from A. annua, such as compounds 267 and 263 (Scheme 1). This propensity towards spontaneous autoxidation has also been suggested for several other terpenoidal hydroperoxides from A. annua, and it is repeatedly stressed in this review because of its perceived relvance to the biosynthesis of artemisinin (Section 3.3). Compounds $\mathbf{2 7 1}$ and $\mathbf{2 7 2}$ are also derivatives of myrcene, in which oxidation at C-1 and C-10 has produced a 1,4-dihydrofuran functionality, rarely found in natural products. It has been proposed that the biogenesis of the secondary and teriary allylic hydroxide functionality in this pair of compounds might also be explained by similar autoxidation reactions of a putatative monoterpene precursor (closely related to perillene (270)), which also proceeds via a pair of secondary and tertiary allylic hydroperoxide intermediates [9], as is shown in Scheme 1.

Scheme 1. Postulated biosynthesis of allylic hydroperoxides: $\alpha$-myrcene hydroperoxide (265) and $\beta$-myrcene hydroperoxide (264) via spontaneous autoxidation reactions at the trisubstituted bond of the precursor myrcene (254). Further reactions of such allylic hydroperoxides would account for the biogenesis of oxygenated monoterpenes such as (267), (263), (271) and (272).
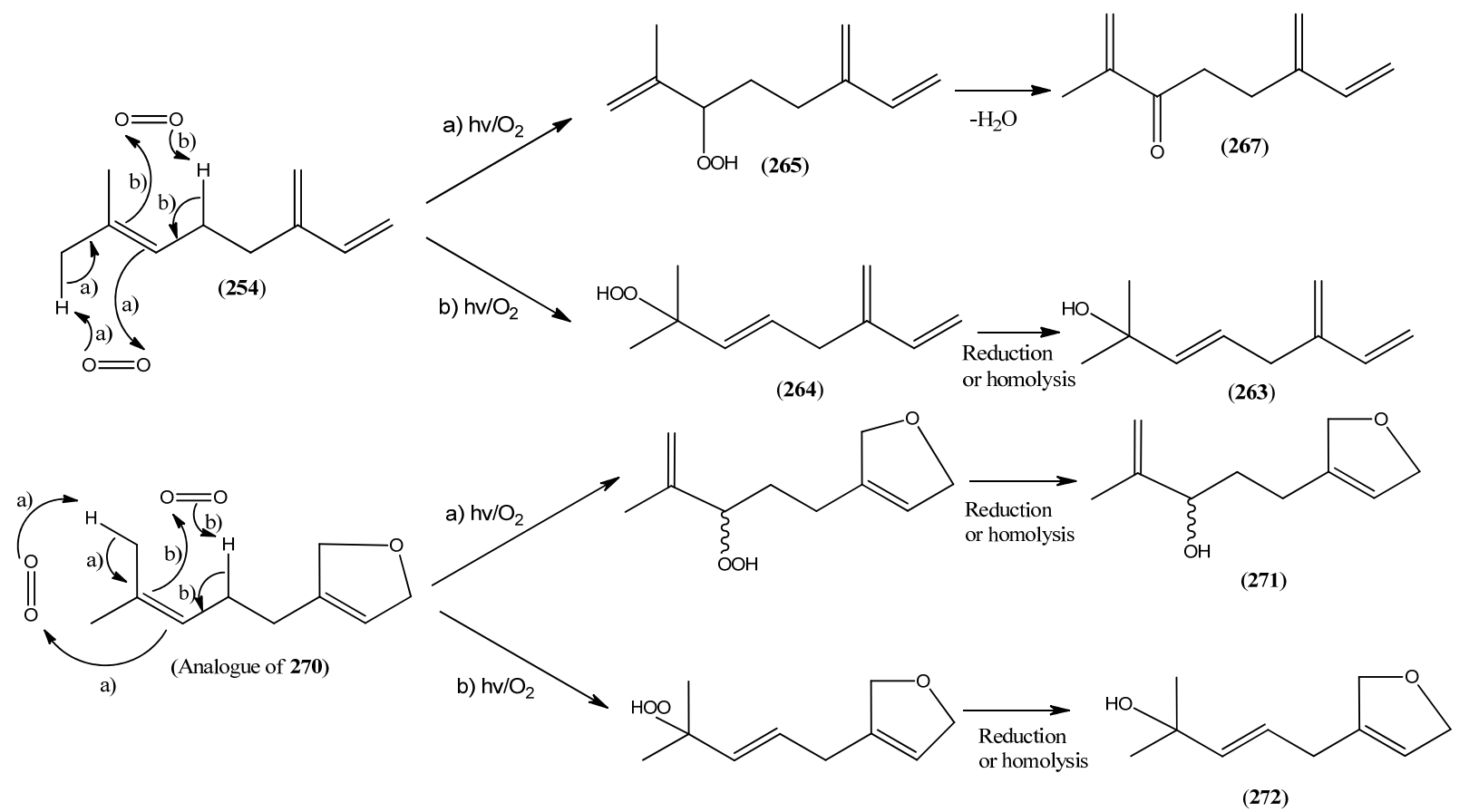

\subsubsection{Irregular Acyclic Monoterpenes}

Phytochemists were interested in A. annua before the discovery of artemisinin because it is a rich source of unusual irregular acyclic monoterpenoids, such as artemisia ketone (276) [115-120], which is the major constituent of the essential oil in some varieties of $A$. annua $[29,37,42,73]$, and can account for up to $50 \%$ of the total $[22,25,33,43,45,53]$. It is often found in conjunction with smaller amounts of artemisia alcohol (273) [22,33,38,121]. Artemisia ketone (276) is formed by a non-standard "head-tomiddle" condensation of DMAPP [104,122-126], which is thought to proceed as shown in Scheme 2 
via chrysanthemyl pyrophosphate, an intermediate containing a three-membered ring. The mechanism for the formation of this unusual intermediate [127], is believed to mimic the formation of presqualene, another naturally-occuring cyclopropane, which is involved in the biosynthesis of the triterpene precursor, squalene (see Section 2.7.2) [128]. Two other classes of irregular cyclic monoterpenoids, the lavandulanes 279)-281 and the santolinanes $\mathbf{2 8 2}$ and 283, are also known from A. annua. The formation of all three skeletons has been explained in terms of different cleavage reactions occurring at each of the three carbon-carbon bonds in the cyclopropyl ring of the common precursor, chysanthemyl pyrophosphate (Scheme 2) [126].

Scheme 2. Formation of the irregular artemisyl, lavandulyl and santolinyl skeletons in $A$. annua by "head-to-middle" condensation of a DMAPP $\left(\mathrm{C}_{5}\right)$ precursor and subsequent carbon-carbon cleavage reactions of the resulting intermediate, chryanthemyl pyrophosphate.

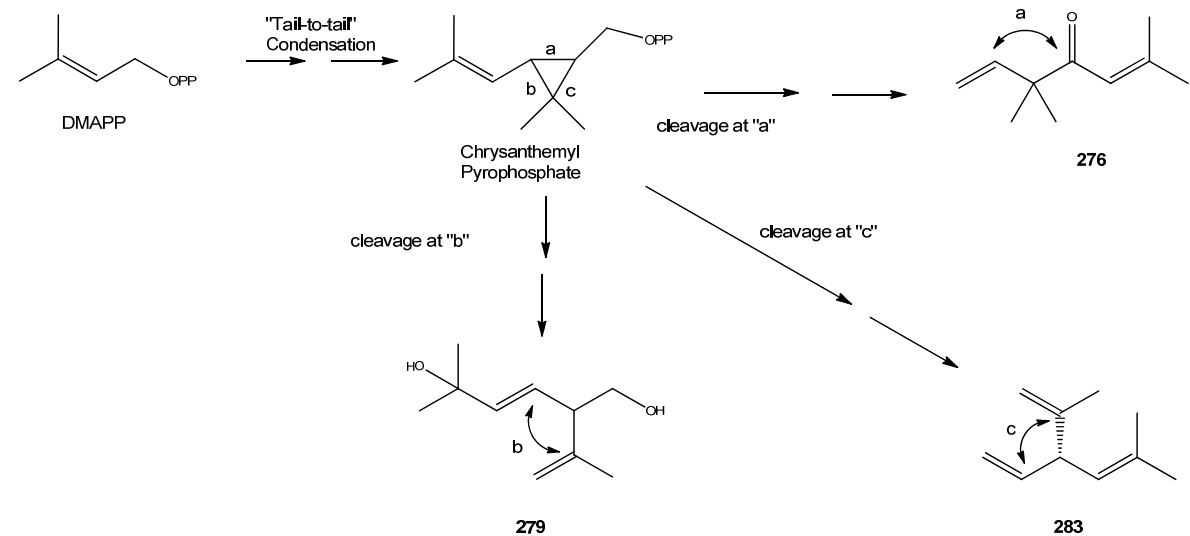

Table 24. Irregular Acyclic Monoterpenoids.

\begin{tabular}{|c|c|c|c|}
\hline Name & Alternative Name(s) & CAS Number & References \\
\hline \multicolumn{4}{|l|}{ Artemisanes } \\
\hline Artemisia alcohol (273) & 3,3,6-Trimethyl-1,5-heptadien-4-ol & $\begin{array}{l}{[29887-38-5]} \\
{[27644-04-8]} \\
{[77363-66-7]}\end{array}$ & $\begin{array}{l}{[19,23,29,33,38,40,43,45} \\
48,51,66,73,121]\end{array}$ \\
\hline Artemisyl acetate (274) & $\begin{array}{l}\text { Artemisia alcohol acetate } \\
3,3,6 \text {-Trimethyl-1,5-heptadien-4-ol acetate }\end{array}$ & $\begin{array}{l}{[3465-88-1]} \\
{[29887-38-5]}\end{array}$ & {$[25,40,43,45,72,112,113]$} \\
\hline $\begin{array}{l}\text { (E)-2-Butenoic acid, 2-methyl-, 2,2- } \\
\text { dimethyl-1-(2-methyl-1-propenyl)- } \\
\text { 3-butenyl ester (275) }\end{array}$ & & {$[62594-30-3]$} & {$[30]$} \\
\hline Artemisia ketone (276) & 3,3,6-Trimethyl-1,5-heptadien-4-one & {$[546-49-6]$} & $\begin{array}{l}{[19,21-24,26,29,31,33,36,} \\
38,40-45,49,53,66,72,73, \\
112,113,121]\end{array}$ \\
\hline Yomogi alcohol (277) & 2,5,5-Trimethyl-3,6-heptadien-2-ol & {$[26127-98-0]$} & {$[19,32,38,45]$} \\
\hline Artemisiatriene (278) & 2,5,5-Trimethyl-1,3,6-heptatriene & {$[29548-02-5]$} & [23] \\
\hline \multicolumn{4}{|l|}{ Lavandulanes } \\
\hline $\begin{array}{l}\text { trans-5-Hydroxy-2-isopropenyl-5- } \\
\text { methylhex-3-en-1-ol (279) } \\
\text { 4-Hydroxy-2-isopropenyl-5- } \\
\text { methylene-hexan-1-ol (280) }\end{array}$ & $\begin{array}{l}\text { 3-Hexene-1,5-diol, 5-methyl-2-(1-methyl- } \\
\text { ethenyl)- }\end{array}$ & [403797-33-1] & $\begin{array}{l}{[129]} \\
{[9]}\end{array}$ \\
\hline Lavandulyl acetate (281) & 5-Methyl-2-(1-methylethenyl)-4-hex-en-1-ol & [20777-39-3] & [19] \\
\hline \multicolumn{4}{|l|}{ Santolinanes } \\
\hline $\begin{array}{l}\text { Santolina alcohol (282) } \\
\text { Santolinatriene (283) }\end{array}$ & $\begin{array}{l}\text { 3-Ethenyl-2,5-dimethyl-4-hexen-2-ol } \\
\text { 3-Ethenyl-2,5-dimethyl-1,4-hexadiene }\end{array}$ & $\begin{array}{l}{[35671-15-9]} \\
{[70005-95-7]} \\
{[2153-66-4]}\end{array}$ & $\begin{array}{l}{[19,32,43]} \\
{[23,25,43,45,50]}\end{array}$ \\
\hline
\end{tabular}


Table 24. Cont.

(273) $\mathrm{R}=\mathrm{H}$

(274) $\mathrm{R}=(\mathrm{C}=\mathrm{O}) \mathrm{CH}_{3}$

(275<smiles>CC=C(C)C=O</smiles><smiles>C=C(C)C(O)CC(CO)C(=C)C</smiles>

(280)
(276)<smiles>C=CC(C)(C)/C=C/C(=C)C</smiles>

(278)<smiles>C=C(C)C(CC=C(C)C)CCOC(C)=O</smiles>

(281)
(277)<smiles>C=C(C)C(/C=C/C(C)(C)O)C(C)O</smiles>

(279)

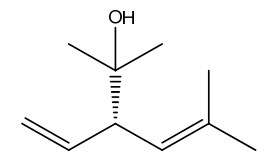

(282)<smiles>C=C[C@@H](C=C(C)C)C(=C)C</smiles>

(283)

Both the lavandulane tertiary allylic alcohol 279 and its secondary allylic alcohol analogue $\mathbf{2 8 0}$ have been proposed to be derived from the precursor, lavandulol, by spontaneous autoxidation reactions which yield allylic hydroperoxide intermediates as shown in Scheme 3 [129]. This suggestion was supported by a biomimetic synthesis, in which photooxygenation of racemic lavandulol yielded both of the hydroperoxide intermediates expected from the reaction of singlet oxygen with the tri-substituted double bond in this precursor. Reduction of the tertiary allylic hydroperoxide product then resulted in a tertiary allylic alcohol identical with the natural product 279.

Scheme 3. Proposed formation of lavandulanes 279 and $\mathbf{2 8 0}$ by spontaneous autoxidation reactions.

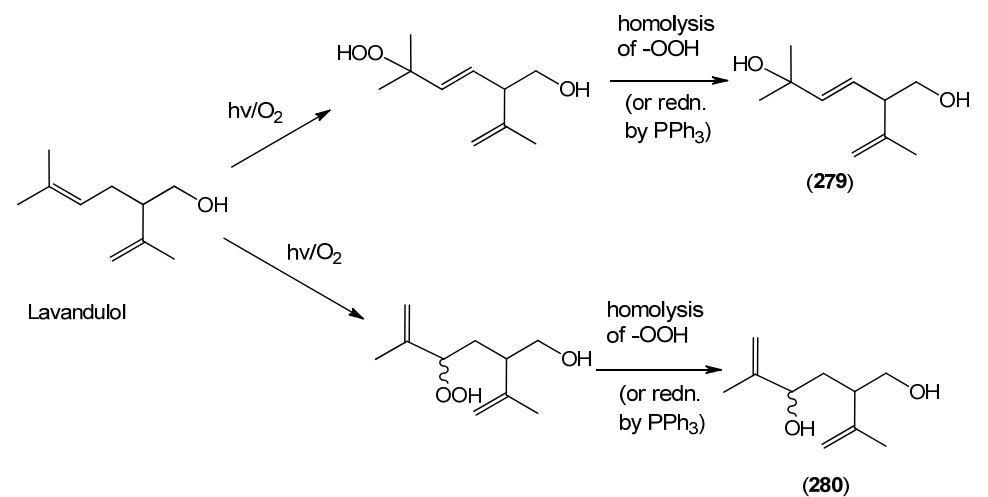

2.5.3. Monocyclic Monoterpenes

Two unusual cyclopentane monoterpeneoids, $\alpha$-campholenal ([4501-58-0]) (284) [19] and cyclopentene, 4-ethenyl-1,5,5-trimethyl- ([1727-69-1]) (285) [23] are reported from A. annua. Both are probably derived from cleavage reactions of the corresponding bicyclic monoterpenoids (see Section 2.5.4). 2-Ochtoden-1-al [26532-25-2] (286) [25] is another unusual six-membered monoterpene, belonging to the ochtodane class of monoterpenoids (3-ethyl-1,1-dimethylcyclohexane, 9CI). The vast 
majority of monocyclic monoterpenes from A. annua, however, are p-menthanes (Table 25), incorporating a six-membered ring, which is formed directly by cyclization of an LPP/NPP precursor.

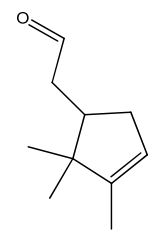

(284)

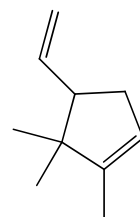

(285)

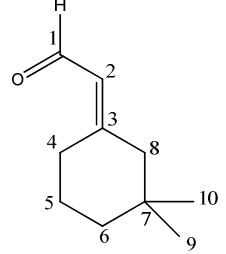

(286)

Table 25. $p$-Menthane Monoterpenoids, 8CI (1-Methyl-4-(1-methylethyl)cyclohexane, 9CI).

\begin{tabular}{|c|c|c|c|}
\hline Name & Alternative Name(s) & CAS number & References \\
\hline$p$-Menth-3-ene (287) & & {$[500-00-5]$} & {$[50]$} \\
\hline$p$-Mentha-2,4-diene (288) & & {$[586-68-5]$} & {$[25]$} \\
\hline$\alpha$-Phellandrene (289) & $p$-Mentha-1,5-diene & [99-83-2] & {$[32]$} \\
\hline$\beta$-Phellandrene (290) & $p$-Mentha-1(7),2-diene & {$[555-10-2]$} & {$[22,25,45]$} \\
\hline$\alpha$-Terpinene (291) & $p$-Menthan-1,3-diene & [99-86-5] & $\begin{array}{l}{[19,32,40,41,45,} \\
66,74]\end{array}$ \\
\hline$\gamma$-Terpinene (292) & p-Menthan-1,4,diene & {$[99-85-4]$} & $\begin{array}{l}{[19,28,32,40,41,} \\
43,66]\end{array}$ \\
\hline Terpinolene (293) & $p$-Mentha-1,4(8)-diene & {$[586-62-9]$} & {$[32,43]$} \\
\hline Limonene (294) & $p$-Mentha-1,8-diene & $\begin{array}{l}{[138-86-3]} \\
{[5989-27-5]}\end{array}$ & $\begin{array}{l}{[24,31,34,43,45} \\
50,66,111]\end{array}$ \\
\hline p-Cymene (295) & 1-Methyl-4-isopropyl benzene & [99-87-6] & $\begin{array}{l}{[19,24,25,28,29,} \\
32,34,38,40,43,45, \\
48,73,74]\end{array}$ \\
\hline Cuminic alcohol (296) & $\begin{array}{l}\text { p-Mentha-1,3,5-trien-7-ol } \\
\text { 4-Isopropenylbenzyl alcohol }\end{array}$ & {$[536-60-7]$} & {$[51]$} \\
\hline Cuminal (297) & $\begin{array}{l}\text { Cuminaldehyde } \\
\text { p-Menthan-1,3,5-trien-1-al } \\
\text { 4-Isopropylbenzaldehyde }\end{array}$ & [122-03-2] & {$[23,25,32,43,45]$} \\
\hline Carvacrol (298) & $p$-Mentha-1,3,5-trien-2-ol & {$[499-75-2]$} & {$[31,32,43]$} \\
\hline Thymol (299) & $\begin{array}{l}p \text {-Cymen-3-ol } \\
p \text {-Mentha-1,3,5-trien-3-ol }\end{array}$ & {$[89-83-8]$} & {$[19,32,43]$} \\
\hline$p$-Cymen-8-ol (300) & 2-(4-Methylphenyl)-2-propanol & [1197-01-9] & {$[19,25,32]$} \\
\hline Menthol (301) & $p$-Menthan-3-ol & {$[89-78-1]$} & {$[23,25,30,60,111]$} \\
\hline$\beta$-Terpineol (302) & p-Menth-8-en-1-ol & [7299-41-4] & {$[43]$} \\
\hline cis-p-Menth-2-en-1-ol (303) & & [29803-81-4] & {$[19,45]$} \\
\hline trans-p-Menth-2-en-1-ol (304) & & {$[29803-82-5]$} & {$[19,45]$} \\
\hline$p$-Menth-2,8-dien-1-ol (305) & $\begin{array}{l}\text { 1-Methyl-4-(1-methylethyl)-2-cyclohexen-1- } \\
\text { ol }\end{array}$ & [3886-78-0] & [32] \\
\hline trans-Carveol (306) & p-Mentha-1,8-dien-6-ol, trans- & {$[1197-07-5]$} & {$[19,25,41,43,45]$} \\
\hline cis-Carveol (307) & p-Mentha-1,8-dien-6-ol, cis- & [1197-06-4] & {$[19,41,43]$} \\
\hline trans-Carvyl acetate $\mathbf{( 3 0 8 )}$ & p-Mentha-6,8-dien-2-ol, acetate, trans- & [1134-95-8] & {$[19,31]$} \\
\hline cis-Carvyl acetate (309) & p-Mentha-6,8-dien-2-ol, acetate, cis- & {$[1205-42-1]$} & {$[19]$} \\
\hline Carvone (310) & $p$-Mentha-1,8-dien-6-one & {$[99-49-0]$} & $\begin{array}{l}{[19,24,25,28,32,} \\
43]\end{array}$ \\
\hline p-Mentha-1(7),5-dien-2-ol (311) & & {$[30681-15-3]$} & {$[43]$} \\
\hline p-Mentha-1(7),8-dien-2-ol (312) & & [35907-10-9] & {$[51]$} \\
\hline$p$-Menth-1-en-5-ol (313) & & [55708-42-4] & {$[22]$} \\
\hline p-Mentha-1,4(8)-dien-3-ol (314) & & {$[6753-08-8]$} & [32] \\
\hline $\begin{array}{l}\text { 3-Cyclohexene-1-methanol 2-hydroxy- } \\
\alpha, \alpha, 4 \text {-trimethyl-, 1-acetate (315) }\end{array}$ & & [138913-54-9] & {$[25]$} \\
\hline Iso-menthone (316) & p-Menthan-3-one & {$[491-07-6]$} & {$[45]$} \\
\hline Piperitone (317) & -Menth-1-en-3-one & {$[89-81-6]$} & {$[24]$} \\
\hline Terpinen-4-ol (318) & $p$-Menth-1-en-4-ol & {$[562-74-3]$} & $\begin{array}{l}{[19,30,31,32,34} \\
41,43,45,51,66]\end{array}$ \\
\hline
\end{tabular}


Table 25. Cont.

\begin{tabular}{|c|c|c|c|}
\hline 4-Terpinyl acetate (319) & p-Menth-1-en-4-ol acetate & [4821-04-9] & [34] \\
\hline Phellandral (320) & p-Menth-1-en-7-al & [21391-98-0] & [23] \\
\hline Perillaldehyde (321) & p-Mentha-1,8-dien-7-al & [2111-75-3] & {$[45]$} \\
\hline$\alpha$-Terpineol (322) & $\begin{array}{l}\text { 1- } \alpha \text {-Terpineol } \\
p \text {-Menth-1-en-8-ol }\end{array}$ & $\begin{array}{l}{[98-55-5]} \\
{[10482-56-1]}\end{array}$ & $\begin{array}{l}{[19,22,23,28,32} \\
40,43,45,74]\end{array}$ \\
\hline$\delta$-Terpineol (323) & p-Menthen-1(7)-en-8-ol & {$[7299-42-5]$} & {$[19]$} \\
\hline Limonene-1,2-epoxide (324) & $\begin{array}{l}\text { Limonene oxide } \\
1,2 \text {-Epoxy- } p \text {-menth- } 8 \text {-ene }\end{array}$ & [1195-92-2] & {$[23,51]$} \\
\hline 1,4-Cineole (325) & 1,4-Epoxy-p-menthane & [470-67-7] & {$[112]$} \\
\hline 1,8-Cineole (326) & $\begin{array}{l}\text { Eucalyptol } \\
1,8 \text {-Epoxy-p-menthane }\end{array}$ & {$[470-82-6]$} & $\begin{array}{l}{[19,22-25,28,29,32,} \\
33,34,36-38,40,41, \\
43,45,48-51,53,66, \\
72-74,112,113]\end{array}$ \\
\hline 2,3-Dihydro-1,8-cineole $\quad(\mathbf{3 2 7})$ & 1,8-Epoxy-p-menth-2-ene & [92760-25-3] & {$[19,32,41,43]$} \\
\hline 2 - $\alpha$-Hydroxy-1,8-cineole (328) & & [60761-00-4] & {$[113]$} \\
\hline Ascaridole (329) & 1,4-Epidioxy-p-menth-2-ene & {$[512-85-6]$} & [28] \\
\hline $\begin{array}{l}\text { 2-Cyclohexen-1-one, 2-methyl-5-(1- } \\
\text { methylcyclopropyl)- (330) }\end{array}$ & & [26541-44-6] & [43] \\
\hline
\end{tabular}<smiles>CC1CC=C(C(C)C)CC1</smiles>

(287)<smiles>C=C(C)C1CC=C(C)CC1</smiles>

(294)<smiles>CC1C=CC(C(C)C)=CC1</smiles>

(288)<smiles>CC1CC=C(C(C)C)CC1</smiles><smiles>CC(C)[C@H]1C=C[C@@](C)(O)CC1</smiles>

(303) $1 \beta-\mathrm{OH}$

(304) $1 \alpha-\mathrm{OH}$<smiles>C=C1CC[C@@H](C(=C)C)C[C@H]1O</smiles>

(312)<smiles>C=C(C)[C@H]1C=C[C@@](C)(O)CC1</smiles>

(305)<smiles>CC1=CCC(C(C)C)C(O)C1</smiles>

(313)<smiles>CC1=CCC(C(C)C)C=C1</smiles>

(289)<smiles>C=C1C=CC(C(C)C)CC1</smiles>

(290)<smiles>CC1=CC=C(C(C)C)CC1</smiles>

(291)<smiles>CC1=CCC(C(C)C)=CC1</smiles>

(292)<smiles>CC1CCC(C(C)C)C(O)C1</smiles>

(301)<smiles>C=C(C)[C@H]1CC=C(C)C(=O)C1</smiles>

(310)<smiles>CC1=CC(O)C(=C(C)C)CC1</smiles>

(314)

(306) $\mathrm{R}=2 \beta-\mathrm{OH}$

(307) $\mathrm{R}=2 \alpha-\mathrm{OH}$

(308) $\mathrm{R}=2 \beta-\mathrm{O}(\mathrm{C}=\mathrm{O}) \mathrm{CH}_{3}$

(309) $\mathrm{R}=2 \alpha-\mathrm{O}(\mathrm{C}=\mathrm{O}) \mathrm{CH}_{3}$<smiles>CC(=O)OC(C)(C)C1CCC(C)=CC1O</smiles>

(315)<smiles>CC(C)[C@H]1CC[C@@H](C)CC1=O</smiles>

(316)<smiles>CC1=CC(=O)C(C(C)C)CC1</smiles>

(317)
(311)<smiles>C=C1C=C[C@@H](C(C)C)C[C@H]1O</smiles><smiles>[R9]C1(C(C)C)CC=C(C)CC1</smiles>

(318) $\mathrm{R}=\mathrm{H}$ (319)

$\mathrm{R}=(\mathrm{C}=\mathrm{O}) \mathrm{CH}_{3}$ 
<smiles>CC(C)[C@H]1CC=C(C=O)CC1</smiles>

(320)<smiles>C=C(C)[C]1CC=C(C=O)CC1</smiles>

(321)<smiles>CC1=CC[C@H](C(C)(C)O)CC1</smiles>

(322)<smiles>C=C1CCC(C(C)(C)O)CC1</smiles>

(323)<smiles>C=C(C)[C@H]1CC[C@@]2(C)OC2C1</smiles>

(324)<smiles>CC(C)[C@]12CC[C@](C)(CC1)O2</smiles>

(325)<smiles>CC12CCC(O1)C(C)(C)C2</smiles>

(326)

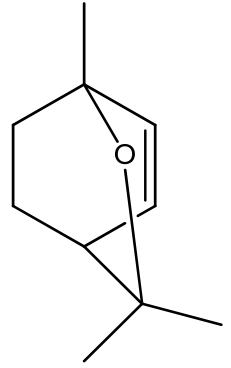

(327)

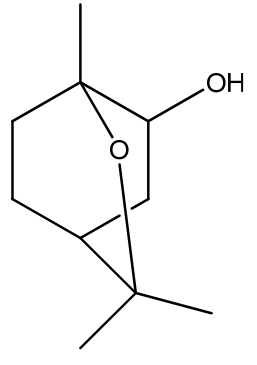

(328)<smiles>CC(C)C12C=CC(C)(CC1)OO2</smiles>

(329)<smiles>CC1=CCC(C2(C)CC2)CC1=O</smiles>

(330)

1,8-Cineole (326) is the most abundant $p$-menthane monoterpene from $A$. annua $[22,29,40,42,43,45,73]$, accounting for as much as $10-30 \%$ of the essential oil $[25,28,33,34,41,53]$. 1,8-Cineole is sometimes accompanied by significant quantities of $p$-cymene (295) $[28,34]$ and $\alpha$-terpineol (322) [28], which could be derived from opening of the ether linkage in 1,8-cineole (326).

Only two o-menthanes: o-cymene (1-isopropyl-2-methylbenzene [527-84-4] [25155-15-1]) (331) [41] and $o$-mentha-1(7),8-dien-3-ol ([15358-81-3]) (332) [23]; and one $m$-menthane: $m$-cymene ( $\beta$-cymene; 1-methyl-3-(1-methylethyl)benzene [535-77-3]) (333) [31] are reported from A. annua. These unusual skeletons presumably arise by migration of a methyl group in the corresponding $p$ menthane precursor (i.e. $\mathbf{3 3 1}$ and $\mathbf{3 3 3}$ are perhaps derived from 295).<smiles>Cc1ccccc1C(C)C</smiles>

(331)<smiles>C=C(C)C1C(=C)CCCC1O</smiles>

(332)<smiles>Cc1cccc(C(C)C)c1</smiles>

(333)

\subsubsection{Bicyclic Monoterpenes}

Further cyclization of the carbocation which produces the $p$-menthane skeleton results in bicyclic monoterpenes. In the camphane monoterpenes listed in Table 26, the second cyclization has produced an additional five-membered ring. The most abundant member of this class of monoterpenoids is camphor (341) $[25,29,37,45]$, which can account for up to $10-30 \%$ of the essential oil $[19,22,41,42]$. Borneol (334) [46,73] and bornyl acetate (335) [29] are sometimes reported together with camphor (351) as significant constituents of the essential oil. 
Table 26. Camphane Monoterpenoids (1,7,7-Trimethylbicyclo-[2.2.1]heptane, 9CI).

\begin{tabular}{|c|c|c|c|}
\hline Name & Alternative Name(s) & CAS Number & References \\
\hline Borneol (334) & & $\begin{array}{l}{[464-43-7]} \\
{[507-70-0]} \\
{[124-76-5]} \\
\end{array}$ & $\begin{array}{l}{[19,25,29,30,31,34,40,41,} \\
43,45,72,73,111,112]\end{array}$ \\
\hline Bornyl acetate (335) & & $\begin{array}{l}{[76-49-3]} \\
{[92618-89-8]}\end{array}$ & {$[25,31,40,45]$} \\
\hline Borneol isobutyrate (336) & & {$[24717-86-0]$} & {$[45]$} \\
\hline Bornyl valerate (337) & Bornyl pentanoate & {$[7549-41-9]$} & [31] \\
\hline $\begin{array}{l}\text { 2-Butenoic acid, 3-methyl- } \\
(1 S, 2 R, 4 S)-1,7,7- \\
\text { trimethylbicyclo[2.2.1]hept-2-yl ester } \\
\text { (338) }\end{array}$ & & [91404-82-9] & [31] \\
\hline $\begin{array}{l}\text { Cyclopentanecarboxylic acid, 3- } \\
\text { methylene-, 1,7,7-trimethylbicyclo- } \\
\text { [2.2.1]hept-2-yl ester (339) }\end{array}$ & & [74793-59-2] & {$[31]$} \\
\hline Isobornyl acetate $(\mathbf{3 4 0})$ & 2-Bornanol acetate & {$[125-12-2]$} & {$[19]$} \\
\hline Camphor (341) & $\begin{array}{l}\text { 1,7,7-Trimethylbicyclo[2.2.1] } \\
\text { heptan-2-one }\end{array}$ & $\begin{array}{l}{[76-22-2]} \\
{[464-48-2]}\end{array}$ & $\begin{array}{l}{[19,23,25,26,29,32,34,} \\
36-38,40-45,48,49,51,53, \\
66,72-74,112,113]\end{array}$ \\
\hline endo-Dehydronorborneol (342) & Bicyclo[2.2.1]hept-5-en-2-ol & [694-97-3] & {$[23]$} \\
\hline
\end{tabular}

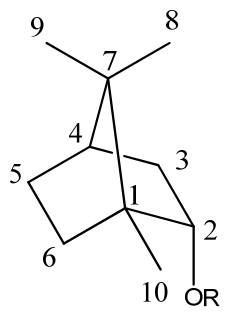

(334) $\mathrm{R}=\mathrm{H}$

(335) $\mathrm{R}=(\mathrm{C}=\mathrm{O}) \mathrm{CH}_{3}$

(336) $\mathrm{R}=(\mathrm{C}=\mathrm{O}) \mathrm{CH}\left(\mathrm{CH}_{3}\right)_{2}$

(337) $\mathrm{R}=(\mathrm{C}=\mathrm{O})\left(\mathrm{CH}_{2}\right)_{3} \mathrm{CH}_{3}$

(338) $\mathrm{R}=(\mathrm{C}=\mathrm{O}) \mathrm{CH}=\mathrm{C}\left(\mathrm{CH}_{3}\right)_{2}$

(339)

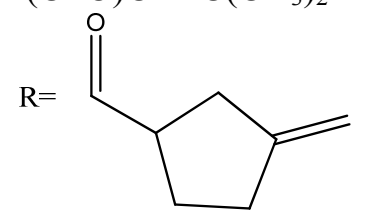

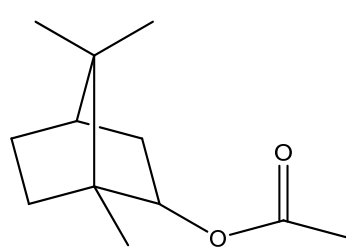

(340)

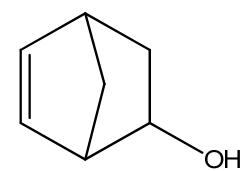

(342)

Other miscellaneous bicyclic monoterpenoids which contain both 5- and 6-membered rings are: camphene (2,2-dimethyl-3-methylenebicyclo[2.2.1] heptane [79-92-5]) (343) [19,23,25,26,28,29,31,32, 34,36,37,40,41,43,45,51,73,74,130]; camphene hydrate ([465-31-6]) (344) [19]; fenchol (fenchyl alcohol; 1,3,3-trimetylbicyclo[2.2.1] heptan-2-ol [1632-73-1]) (345) [66]; and trans-pinene hydrate (2norbornanol, 2,7,7-trimethyl-, endo-; bicyclo[2.2.1]heptan-2-ol, 2,7,7-trimethyl-, endo-; [3247-40-3]) (346) [25]. Camphene (343) has been obtained as both its (+)- and (-)-enantiomeric forms [37].<smiles>C=C1C2CCC(C2)C1(C)C</smiles>

(343)<smiles>CC1(C)C2CCC(C2)C1(C)O</smiles>

(344)

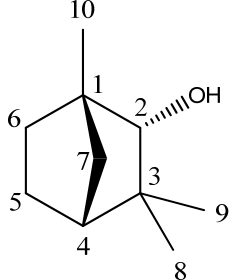

(345)<smiles>CC1CC2CCC1C2(C)C</smiles>

(346) 
In the pinane monoterpenes (Table 27), the second cyclization of the $\mathrm{C}_{10} p$-menthane precursor has produced an additional four-membered ring. $\alpha$-Pinene (347) $[40,42,43]$ is the most abundant pinane monoterpene from A. annua (up to 10\%) [33], and sometimes co-occurrs with significant amounts of either $\beta$-pinene (356) [101] or pinocarvone (360) [42]. A $\beta$-pinene synthase, which converts GPP to both (-)- $\alpha$-pinene (347) and (-)- $\beta$-pinene (356), has recently been described from A. annua [131]. $\alpha-$ Pinene (347) is known in both its (+)- and (-)-enantiomeric forms from this species [37].

Table 27. Pinane Monoterpenoids (2,6,6-Trimethylbicyclo[3.1.1]heptane, 9CI).

\begin{tabular}{|c|c|c|c|}
\hline Name & Alternative Name(s) & CAS Number & References \\
\hline$\alpha$-Pinene (347) & 2,6,6-Trimethylbicyclo[3.1.1]hept-2-ene & $\begin{array}{l}{[80-56-8]} \\
{[7785-26-4]} \\
{[7785-70-8]}\end{array}$ & $\begin{array}{l}{[19,22,25,28,29,32-34,} \\
36-38,40-45,50,51,66,73, \\
74,112,113,120,132]\end{array}$ \\
\hline Verbenyl acetate (348) & $\begin{array}{l}\text { Verbenol acetate } \\
\text { 2-Pinen-4-ol, acetate }\end{array}$ & [33522-69-9] & {$[23]$} \\
\hline trans-Chrysanthenol (349) & & [38043-83-3] & [43] \\
\hline cis-Chrysanthenyl acetate (350) & & [67999-48-8] & [19] \\
\hline Myrtenol (351) & 2-Pinen-10-ol & $\begin{array}{l}{[515-00-4]} \\
{[564-94-3]}\end{array}$ & {$[19,23,32,41,43,66]$} \\
\hline (-)-Myrtenyl acetate (352) & (-)-O-Acetylmyrtenol & {$[36203-31-3]$} & {$[23]$} \\
\hline Verbenone $\quad(\mathbf{3 5 3})$ & 2-Pinen-4-one & {$[80-57-9]$} & {$[19,25,34,43,45]$} \\
\hline Chrysanthenone (354) & 2-Pinen-6-one & [473-06-3] & {$[32,43,66]$} \\
\hline Myrtenal (355) & 2-Pinen-10-al & {$[23727-16-4]$} & {$[66]$} \\
\hline$\beta$-Pinene (356) & $\begin{array}{l}\text { 6,6-Dimethyl-2-methylenebicyclo[3.1.1]- } \\
\text { heptane }\end{array}$ & $\begin{array}{l}{[127-91-3]} \\
{[1330-16-1]}\end{array}$ & $\begin{array}{l}{[19,22,23,25,26,27,28,} \\
32,33,34,36,38,40,43, \\
45,51,66,73,74,112,113, \\
120,132]\end{array}$ \\
\hline (-)-trans-Pinocarveol (357) & 2(10)-Pinen-3-ol & $\begin{array}{l}{[547-61-5]} \\
{[3917-59-7]}\end{array}$ & {$[19,23,25,32,33,40,43]$} \\
\hline cis-Pinocarveol (358) & $\begin{array}{l}\text { Isopinocarveol } \\
\text { 2(10)-Pinen-3-ol, cis- }\end{array}$ & $\begin{array}{l}{[6712-79-4]} \\
{[5947-36-4]}\end{array}$ & {$[30,43]$} \\
\hline Pinocarvyl acetate (359) & 2(10)-Pinen-3-ol, acetate & {$[1078-95-1]$} & {$[30]$} \\
\hline Pinocarvone $(\mathbf{3 6 0})$ & 2(10)-Pinen-3-one & $\begin{array}{l}{[30460-92-5]} \\
{[19890-00-7]}\end{array}$ & $\begin{array}{l}{[19,23,25,28,30,32,33,} \\
42,43,45,66]\end{array}$ \\
\hline 3-Pinanol (361) & 2,6,6-Trimethylbicyclo[3.1.1]heptan-3-ol & [25465-95-6] & {$[30]$} \\
\hline$\beta$-Pinene oxide (362) & 2,10-Epoxypinane & [6931-54-0] & [19] \\
\hline $\begin{array}{l}\text { Bicyclo[3.1.1]heptan-3-one, 2,6,6- } \\
\text { trimethyl-4-methylene- (363) }\end{array}$ & & [62594-31-4] & {$[30]$} \\
\hline
\end{tabular}

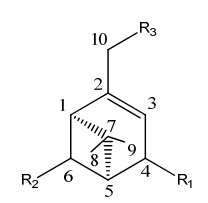

(347) $\mathrm{R}_{1}=\mathrm{H} ; \mathrm{R}_{2}=\mathrm{H} ; \mathrm{R}_{3}=\mathrm{H}$

(348) $\mathrm{R}_{1}=\mathrm{O}-(\mathrm{C}=\mathrm{O}) \mathrm{CH}_{3} ; \mathrm{R}_{2}=\mathrm{H} ; \mathrm{R}_{3}=\mathrm{H}$

(349) $\mathrm{R}_{1}=\mathrm{H} ; \mathrm{R}_{2}=\beta-\mathrm{OH} ; \mathrm{R}_{3}=\mathrm{H}$

(350) $\mathrm{R}_{1}=\mathrm{H} ; \mathrm{R}_{2}=\alpha-\mathrm{O}-(\mathrm{C}=\mathrm{O}) \mathrm{CH}_{3} ; \mathrm{R}_{3}=\mathrm{H}$

(351) $\mathrm{R}_{1}=\mathrm{H} ; \mathrm{R}_{2}=\mathrm{H} ; \mathrm{R}_{3}=\mathrm{OH}$

(352) $\mathrm{R}_{1}=\mathrm{H} ; \mathrm{R}_{2}=\mathrm{H} ; \mathrm{R}_{3}=\mathrm{O}-(\mathrm{C}=\mathrm{O}) \mathrm{CH}_{3}$

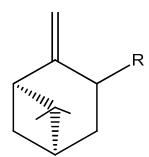

(356) $\mathrm{R}=\mathrm{H}$

(357) $\mathrm{R}=\beta-\mathrm{OH}$

(358) $\mathrm{R}=\alpha-\mathrm{OH}$

(359) $\mathrm{R}=\alpha-\mathrm{O}-(\mathrm{C}=\mathrm{O}) \mathrm{CH}_{3}$

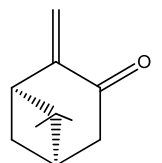

(360)

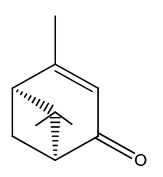

(353)

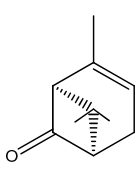

(354)

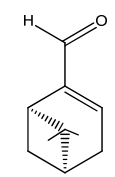

(355)

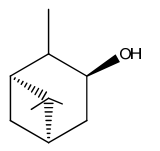

(361)

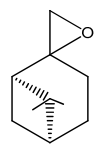

(362)

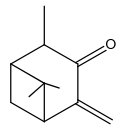

(363) 
Only two caranes (3,7,7-trimethylbicyclo[4.1.0]heptane, 9CI): $\alpha$-carene ([13466-78-9]) (364) [32,41] and 2-acetyl-3-carene ([40824-36-0]) (365) [23] are known from A. annua: the majority of monoterpenes which incorporate an additional three-membered ring belong to the thujane class (Table 28). Two of the most abundant thujanes are sabinene hydrate (373) [34] and sabinol (371) [43], both of which can be present at around levels of $7 \%$ of the total essential oil.

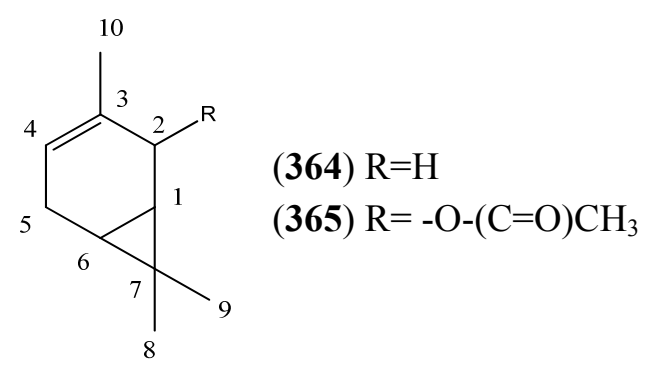

Table 28. Thujane Monoterpenoids (4-Methyl-1-(1-methylethyl)-bicyclo[3.1.0]hexane, 9CI).

\begin{tabular}{|c|c|c|c|}
\hline Name & Alternative Name(s) & CAS Number & References \\
\hline$\alpha$-Thujene (366) & $\begin{array}{l}\text { 3-Thujene } \\
\text { 2-Methyl-5-(1-methylethyl)bicyclo[3.1.0]hex-2-ene }\end{array}$ & {$[2867-05-2]$} & $\begin{array}{l}{[28,34,41} \\
43,45,66]\end{array}$ \\
\hline 3-Thujen-2-ol (367) & Bicyclo[3.1.0]hex-3-en-2-ol, 4-methyl-1-(1-methylethyl) & [3310-03-0] & {$[25]$} \\
\hline 3-Thujen-10-al (368) & & [57129-54-1] & {$[50]$} \\
\hline (-)- $\alpha$-Thujone (369) & & [546-80-5] & {$[45,66,111]$} \\
\hline Sabinene (370) & 4(10)-Thujene & [2009-00-9] & {$[19,23,31$} \\
\hline & Bicyclo[3.1.0]hexane,4-methylene-1-(1-methylethyl)- & $\begin{array}{l}{[3387-41-5]} \\
{[204524-73-2]}\end{array}$ & $\begin{array}{l}32,34,40,41 \\
43,45,51,66 \\
74,113]\end{array}$ \\
\hline Sabinol (371) & $4(10)$-Thujen-3-ol & [471-16-9] & {$[32,43]$} \\
\hline trans-Sabinyl acetate (372) & Bicyclo[3.1.0]hexan-3-ol, 4-methylene-1-(1-methylethyl)-, 3-acetate & $\begin{array}{l}{[139757-62-3]} \\
{[3536-54-7]}\end{array}$ & [43] \\
\hline$\beta$-Sabinene hydrate (373) & 4-Thujanol & $\begin{array}{l}{[546-79-2]} \\
{[15537-55-0]} \\
{[17699-16-0]}\end{array}$ & $\begin{array}{l}{[19,25,32,} \\
34,41,43,45]\end{array}$ \\
\hline Sabina ketone (374) & $\begin{array}{l}\text { Didehydrosabina ketone } \\
\text { Bicyclo[3.1.0]hexan-2-one, 5-(1-methylethyl)-, 5-Isopropyl- } \\
\text { bicyclo[3.1.0] hexan-2-one }\end{array}$ & $\begin{array}{l}{[513-20-2]} \\
{[110716-99-9]} \\
{[147043-52-5]}\end{array}$ & {$[19,43]$} \\
\hline
\end{tabular}<smiles>[R]C1=CC([R])C2CC1C2(C)C</smiles>

(366) $\mathrm{R}_{1}=\mathrm{H} ; \mathrm{R}_{2}=\mathrm{Me}$

(367) $\mathrm{R}_{1}=\mathrm{OH} ; \mathrm{R}_{2}=\mathrm{Me}$

(368) $\mathrm{R}_{1}=\mathrm{H} ; \mathrm{R}_{2}=\mathrm{CHO}$<smiles>CC(C)C1CCC2(C(C)C)CC1C2</smiles>

(369)

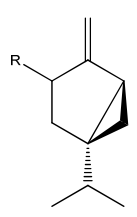<smiles>CC(C)C1CCC2(O)CC1C2</smiles>

(373)

(370) $\mathrm{R}=\mathrm{H}$

(371) $\mathrm{R}=\beta-\mathrm{OH}$

(372) $\mathrm{R}=\beta-\mathrm{O}-(\mathrm{C}=\mathrm{O}) \mathrm{CH}_{3}$<smiles>CC(C)C1CCC(=O)CC1</smiles>

(374)

Tricyclene ([508-32-7] [160339-05-9]) (375) [25,32,41,43,45] is the only tricyclic monoterpenoid known from $A$. annua.

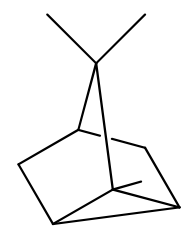

(375) 


\subsection{Sesquiterpenoids}

Sesquiterpenoids $\left(\mathrm{C}_{15}\right)$ constitute the most abundant and most diverse group of natural products from A. annua. All are produced from farnesyl pyrophosphate (FPP; 378), which is the product of a "head-to-tail" condensation of three $\mathrm{C}_{5}$ units (IPP and DMAPP; see Figure 2). Sesquiterpene hydrocarbons are generally more volatile than their highly oxygenated counterparts and are more suited to study by GC-MS ( $c f$. monoterpenes in Section 2.5, which are the other major components of the essential oil from A. annua). More highly oxygenated sesquiterpenes, such as artemisinin (495), are best analysed by liquid chromatography.

\subsubsection{Farnesane Sesquiterpenes}

The farnesanes are the structurally simplest group of sesquiterpenes. This acyclic group of natural products is produced by ionization of the pyrophosphate group in the 15-carbon precursor, FPP (378), followed either by quenching with water or loss of a proton, which results in the variety of structures shown in Table 29. Alternatively, FPP can undergo further cyclization to mono-cyclic sesquiterpenes (Section 2.6.2), bicyclic sesquiterpenes (Section 2.6.3) or tricyclic sesquiterpenes (Section 2.6.4), according to enzymatically-catalysed mechanisms which bear close analogies with the biosynthesis of the cyclized monoterpenoids (Sections 2.5.3 and 2.5.4).

$\beta$-Farnesene (382) is the most abundant member of this class of sesquiterpenes [22,43], constituting up to $10 \%$ of the essential oil [19,27]. A cDNA clone encoding (E)- $\beta$-farnesene synthase, which catalyzes the formation of $\beta$-farnesene (382) from FPP (378), has recently been isolated from $A$. annua [133]. Interestingly, the enzyme amorpha-4,11-diene synthase, which catalyses the formation of the bicyclic sesquiterpene amorpha-4,11-diene, (Section 2.6.3) also produces small amounts of acyclic sesquiterpenes such as trans-nerolidol (380) and (E)-1,3(15),6,10-farnesatetraene (382), both of which are reported as natural products from A. annua [134] (Table 29).

Table 29. Farnesane Sesquiterpenoids (2,6,10-Trimethyldodecane, 9CI).

\begin{tabular}{|c|c|c|c|}
\hline Name & Alternative Name(s) & CAS Number & References \\
\hline Farnesol (376) & $\begin{array}{l}\text { 2,6,10-Farnesatrien-1-ol } \\
\text { 3,7,11-Trimethyl-2,6,10-dodecatrien-1-ol }\end{array}$ & $\begin{array}{l}{[4602-84-0]} \\
{[106-28-5]}\end{array}$ & {$[23,27,135]$} \\
\hline 2,6,10-Farnesatrien-1-ol acetate $(\mathbf{3 7 7})$ & & {$[4128-17-0]$} & {$[27]$} \\
\hline Farnesyl pyrophosphate (378) & $\begin{array}{l}\text { Farnesyl diphosphate } \\
\text { 2,6,10-Dodecatrien-1-ol, 3,7,11-trimethyl-, } \\
\text { trihydrogen pyrophosphate } \\
\text { Diphosphoric acid, mono (3,7,11-trimethyl-2,6,10- } \\
\text { dodecatrienyl) ester }\end{array}$ & {$[13058-04-3]$} & {$[135,136]$} \\
\hline Farnesal (379) & $\begin{array}{l}\text { 2,6,10-Farnesatrien-1-al } \\
\text { 3,7,11-Trimethyl-2,6,10-dodecatrienal }\end{array}$ & [19317-11-4] & {$[27]$} \\
\hline trans-Nerolidol (380) & $\begin{array}{l}\text { 3,6,10-Farnesatrien-3-ol } \\
\text { 3,7,11-Trimethyl-1,6,10-dodecatrien-3-ol }\end{array}$ & $\begin{array}{l}{[7212-44-4]} \\
{[3790-78-1]}\end{array}$ & $\begin{array}{l}{[19,23,27,32,43,45,} \\
134]\end{array}$ \\
\hline (E)-Nerolidyl acetate $(\mathbf{3 8 1})$ & $\begin{array}{l}\text { (E)-Nerolidol acetate } \\
\text { 1,6,10-Dodecatrien-3-ol, 3,7,11-trimethyl-, 3-acetate }\end{array}$ & {$[85611-33-2]$} & {$[27]$} \\
\hline trans- $\beta$-Farnesene (382) & $\begin{array}{l}\text { (E)-1,3(15),6,10-Farnesatetraene } \\
\text { (E)-7,11-Dimethyl-3-methylene-1,6,10-dodecatriene }\end{array}$ & $\begin{array}{l}{[77129-48-7]} \\
{[18794-84-8]}\end{array}$ & $\begin{array}{l}{[19,22,27,30,32,43,48,} \\
50,51,66,134,135]\end{array}$ \\
\hline$(Z)-1,3(15), 6,10$-Farnesatetraene $(\mathbf{3 8 3})$ & & {$[28973-97-9]$} & {$[23,31,32]$} \\
\hline$\alpha$-Farnesene (384) & $\begin{array}{l}\text { 1,3,6,10-Farnesatetraene } \\
\text { 3,7,11-Trimethyl-1,3,6,10-dodecatetraene }\end{array}$ & $\begin{array}{l}{[502-61-4]} \\
{[125037-13-0]}\end{array}$ & {$[27,41,48,50,74,111]$} \\
\hline
\end{tabular}


Table 29. Cont.<smiles>[R]CC=C(C)CCC=C(C)CCC=C(C)C</smiles>

(376) $\mathrm{R}=\mathrm{H}$

(377) $\mathrm{R}=(\mathrm{C}=\mathrm{O}) \mathrm{CH}_{3}$

(378) $\mathrm{R}=(\mathrm{P}=\mathrm{O})(\mathrm{OH})-\mathrm{O}-(\mathrm{P}=\mathrm{O})(\mathrm{OH})_{2}$<smiles>[R7][C@@](C)(C=C)CC/C=C(\C)CCC=C(C)C</smiles>

(380) $\mathrm{R}=\mathrm{H}$

(381) $\mathrm{R}=(\mathrm{C}=\mathrm{O}) \mathrm{CH}_{3}$<smiles>C=CC(=C)CC/C=C(/C)CCC=C(C)C</smiles>

(383)<smiles>CC(C)=CCC/C(C)=C/CC/C(C)=C/C=O</smiles><smiles>C=CC(=C)CCC=C(C)CCC=C(C)C</smiles>

(382)<smiles>C=C/C(C)=C/C/C=C(\C)CCC=C(C)C</smiles>

(384)

\subsubsection{Monocyclic Sesquiterpenes}

The six-membered ring in the bisabolane sesquiterpenes from A. annua (Table 30) is formed by cyclization of the $\mathrm{C}_{15}$ precursor, FPP (378), in much the same way that the $p$-menthane monoterpenes (Section 2.5.3) arise from the corresponding $\mathrm{C}_{10}$ precursor. Alternative cyclizations of FPP can lead to the ten-membered germacrane sesquiterpenes, which are described in Table 31, and the elevenmembered humulane sesquiterpenes in Table 33. The bicyclic caryophyllanes, which are formed by a further cyclization of a humulane precursor, have also been included in Table 33.

\subsubsection{Bisabolanes}

$\alpha$ - and $\beta$-Bisabolene are the most abundant bisabolane sesquiterpenes from A. annua, constituting up to $5 \%$ of the essential oil $[28,46]$. The bisabolane sesquiterpene, $\alpha$-bisabolol $(\mathbf{3 8 5})$, has been found as a minor product from the enzyme amorpha-4,11-diene synthase from A. annua (Section 2.6.3) [136]. Several other bisabolanes, which have not yet been reported as natural products from A. annua, were also obtained from the cyclization of FPP which is catalysed by this enzyme [134] [these included zingiberene; $\beta$-sesquiphellandrene; and zingiberenol (see Figure 3, Section 3.1)].

Table 30. Bisabolanes Sesquiterpenoids (1-(1,5-Dimethylhexyl)-4-methylcyclohexane, 9CI).

\begin{tabular}{|l|l|l|l|}
\hline Name & Alternative Name(s) & CAS Number & References \\
\hline$\alpha$-Bisabolol (385) & & {$[515-69-5]$} & {$[31,32,43,45,134]$} \\
\hline cis-Lanceol (386) & $2,7(14), 10-B i s a b o l a t r i e n-12-o l$ & {$[147129-37-1]$} & {$[46]$} \\
\hline 2,7,10-Bisabolatriene (387) & & {$[58845-44-6]$} & {$[28]$} \\
\hline 2,3-Epoxy-7,10-bisaboladiene (388) & & {$[111536-37-9]$} & {$[23]$} \\
\hline $\begin{array}{l}\text { 7-Oxabicyclo[4.1.0]heptane, 4-(1,5-dimethyl-4-hexen-1- } \\
\text { ylidene)-1-methyl-, }(1 R, 4 Z, 6 S)-(\mathbf{3 8 9})\end{array}$ & {$[94347-02-1]$} & {$[31]$} \\
\hline
\end{tabular}


Table 30. Cont.<smiles>CC(C)=CCC[C@](C)(O)[C@H]1CC=C(C)CC1</smiles>

(385)<smiles>C=C(CC/C=C(\C)CO)[C@H]1CC=C(C)CC1</smiles>

(386)<smiles>CC(C)=CC/C=C(/C)C1CC=C(C)CC1</smiles>

(387)<smiles>CC(C)=CC/C=C(/C)C1CCC2(C)OC2C1</smiles>

(388)<smiles>CC(C)=CCC/C(C)=C1/CC[C@@]2(C)O[C@H]2C1</smiles>

(389)

\subsubsection{Germacranes and Elemanes}

Germacrene D (392) is the most abundant member of the germacrane class of sesquiterpenes [22,37,46] and can constitute between $5-20 \%$ of the essential oil $[19,42,43]$. Germacrene A synthase, the enzyme which catalyzes the cyclization of FPP (378) to germacrene A (390), has recently been isolated from the glandular trichomes of $A$. annua [137]. Compound (395) ([24703-35-3]) is the only example of a bicyclogermacrane sesquiterpene so far described from $A$. annua $[19,32,43,45,74]$.

Table 31. Germacrane Sesquiterpenoids (1,7-Dimethyl-4-(1-methylethyl)cyclodecane, 9CI).

\begin{tabular}{|c|c|c|c|}
\hline Name & Alternative Name(s) & CAS Number & References \\
\hline$(+)$-Germacrene A (390) & $\begin{array}{l}\text { Germacrene } \\
(1(10) E, 4(E)) \text {-Germacra-1(10),4,11-triene }\end{array}$ & {$[28028-64-0]$} & {$[74]$} \\
\hline Germacrene B $\quad(\mathbf{3 9 1})$ & $(1(10) E, 4(\mathrm{E})-1(10), 4,7(11)$-Germacratriene & {$[15423-57-1]$} & {$[23,28,46]$} \\
\hline Germacrene D & 1(10),4(15),5-Germacratiene & [23986-74-5] & $\begin{array}{l}{[19,23,31-33,36,} \\
37,42,43,45,48, \\
66,135]\end{array}$ \\
\hline $\begin{array}{l}\text { 1及-Hydroxy-4(15),5(E),10(14)- } \\
\text { germacratriene }(393)\end{array}$ & & & {$[9]$} \\
\hline Pregeijerene $(\mathbf{3 9 4})$ & $\begin{array}{l}\text { 11,12,13-tri-nor-1(10),4,6,-Germacratriene } \\
\text { 1,5-Dimethyl-1,5,7-cyclodecatriene }\end{array}$ & [20082-17-1] & {$[41]$} \\
\hline
\end{tabular}<smiles>C#CC1CCC2=C(C)CCCC2C1</smiles>

(390)<smiles>CCC=C(C)CCC(CC=C(C)C)=C(C)C</smiles>

(391)<smiles>C=C(/C=C/[C@H]([CH2+])C(C)C)CC/C=C(\C)CCC</smiles>

(392) 
Table 31. Cont.<smiles>C=C1CC[C@@H](C(C)C)/C=C/C(=C)[C@@H](O)C1=C</smiles>

(393)<smiles></smiles>

(394)<smiles>CC1=C[C@H]2[C@H](C(C)=CCC1)C2(C)C</smiles>

(395)

The ten-membered germacrane ring frequently occurs with unsaturation at the 1(10) and 4positions, as is apparent from Table 31. The six-membered ring in the elemane sesquiterpenes (Table 32 ) is thought to be formed by Cope rearrangement of such 1(10),4-germacradienes. Elemanes may thus be artifacts which are introduced during the extraction and isolation process, especially, perhaps, as a result of the high temperatures often associated with GC-MS analysis (e.g., 397 may be formed thermally from 391; and 396 may be formed from 390 by just such a pericyclic reaction).

Table 32. Elemane Sesquiterpenoids (1-Ethyl-1-methyl-2,4-bis-(1-methylethyl)cyclohexane, 9CI).

\begin{tabular}{|l|l|l|l|}
\hline Name & Alternative Name(s) & CAS Number & References \\
\hline$\beta$-Elemene (396) & $1,3,11$-Elematriene & {$[33880-83-0]$} & {$[27,31,34,40$,} \\
& & {$[515-13-9]$} & $43,45]$ \\
$\gamma$-Elemene (397) & $1,3,7(11)$-Elematriene & {$[29873-99-2]$} & {$[23,28,31]$} \\
& & {$[3242-08-8]$} & \\
$\delta$-Elemene (398) & $1,3,6$-Elemantriene & {$[20307-84-0]$} & {$[32,48]$} \\
Elemol (399) & 1,3 -Elemadien-11-ol & {$[639-99-6]$} & {$[27]$} \\
Elemyl acetate (400) & Elemol acetate & {$[60031-93-8]$} & {$[19]$} \\
\hline
\end{tabular}<smiles>C=CC(C)C1CC[C@@](C)(C=C)[C@@H](C(=C)C)C1</smiles><smiles>C=C[C@]1(C(=C)C)CCC(C(C)C)=C[C@H]1C(C)C</smiles>

(398)<smiles>C=C[C@]1(C)CCC(=C(C)C)C[C@H]1C(=C)C</smiles>

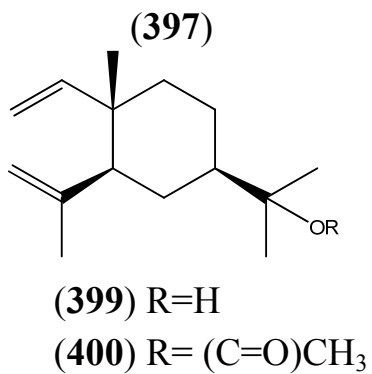

\subsubsection{Humulanes and Caryophyllanes}

$\beta$-Caryophyllene (405) is the most abundant member of this group of sesquiterpenes $[26,37,40,43,46]$ and can be found at levels of up to $5-10 \%$ of the total essential oil $[19,22,42]$. A cDNA clone for $\beta$-caryophyllene synthase, the sesquiterpene cyclase which converts FPP (378) to $\beta$-caryophyllene (405) has now been isolated from A. annua [139]. The $\beta$-caryophyllene synthase gene was found to be expressed widely in most plant tissues during early development, and 
could be induced in mature tissue in response to a fungal elicitor. This was interpreted as evidence that $\beta$-caryophyllene (405) might play a role in plant defense [139]. The enzyme amorpha-4,11-diene synthase from A. annua has been observed to produce small amounts of $\gamma$-humulene (isomeric with $\alpha$ humulene (401) in Table 33 - see also Figure 3, Section 3.1), as well as the expected bicyclic product [134].

Table 33. Humulane Sesquiterpenoids (1,1,4,8-Tetramethylcycloundecane, 9CI) and Caryophyllane Sesquiterpenoids (2,6,10,10-Tetramethylbicyclo[7.2.0]undecane, 9CI).

\begin{tabular}{|c|c|c|c|}
\hline Name & Alternative Name(s) & CAS Number & References \\
\hline \multicolumn{4}{|l|}{ Humulanes } \\
\hline$\alpha$-Humulene (401) & 2,6,9-Humulatriene & {$[6753-98-6]$} & $\begin{array}{l}{[19,27,28,32,40,43,} \\
66]\end{array}$ \\
\hline 14-Hydroxy- $\alpha$-humulene (402) & & {$[108043-85-2]$} & {$[27]$} \\
\hline Humulene epoxide I (403) & 2,3-Epoxy-6,9-humuladiene & {$[19888-33-6]$} & {$[45]$} \\
\hline Humulene epoxide II (404) & 6,7-Epoxy-2,9-humuladiene & [19888-34-7] & {$[27,45]$} \\
\hline \multicolumn{4}{|l|}{ Caryophyllanes } \\
\hline$\beta$-Caryophyllene (405) & (E)-3(15),6-Caryophylladiene & {$[87-44-5]$} & $\begin{array}{l}{[19,22,23,24,26,27,} \\
29,32,36,37,40,41- \\
43,45,48,49,51,66, \\
72-74,112,140]\end{array}$ \\
\hline$\gamma$-Caryophyllene (406) & $\begin{array}{l}\text { Isocaryophyllene } \\
(Z)-3(15), 6 \text {-Caryophylladiene }\end{array}$ & {$[118-65-0]$} & {$[31]$} \\
\hline $\begin{array}{l}\text { (1R,3Z,9S)-Bicyclo[7.2.0]undec-3- } \\
\text { ene, 4,11,11-trimethyl-8-methylene- } \\
\text { (407) }\end{array}$ & & {$[136296-35-0]$} & {$[50]$} \\
\hline Caryophylladienol I (408) & $\begin{array}{l}\text { Caryophyllenol } \\
\text { Bicyclo[7.2.0]undecan-5-ol, 10,10-dimethyl-2,6- } \\
\text { bis(methylene)-, (1S,5S,9R)-Caryophylla- } \\
\text { 4(12),8(13)-dien-5 } 3 \text {-ol }\end{array}$ & $\begin{array}{l}{[19431-80-2]} \\
{[38284-26-3]}\end{array}$ & {$[28,32,43]$} \\
\hline Caryophylladienol II (409) & $\begin{array}{l}\text { Caryophyllenol } \\
\text { Bicyclo[7.2.0]undecan-5-ol, 10,10-dimethyl-2,6- } \\
\text { bis(methylene)-, (1S,5R,9R)-Caryophylla- } \\
\text { 4(12),8(13)-dien-5 } \alpha \text {-ol }\end{array}$ & $\begin{array}{l}{[19431-79-9]} \\
{[38284-26-3]}\end{array}$ & {$[28,32,43]$} \\
\hline Caryophyllene oxide (410) & $\begin{array}{l}\text { Isocaryophyllene oxide } \\
6,7 \text {-Epoxy-3(15)-caryophyllene }\end{array}$ & $\begin{array}{l}{[1139-30-6]} \\
{[113877-94-6]} \\
{[17627-43-9]}\end{array}$ & $\begin{array}{l}{[9,19,23,25,27,30} \\
32,34,43,45,48,49 \\
50,66]\end{array}$ \\
\hline cis-Caryophyllene oxide (411) & $\begin{array}{l}\text { 5-Oxatricyclo[8.2.0.04,6]dodecane, } 4,12,12- \\
\text { trimethyl-9-methylene-, }(1 R, 4 S, 6 R, 10 S) \text { - }\end{array}$ & {$[60594-23-2]$} & {$[32]$} \\
\hline
\end{tabular}<smiles>[2H]/C(C)=C/CC/C=C/C</smiles>

(401) $\mathrm{R}=\mathrm{H}$

(402) $\mathrm{R}=-\mathrm{O}-(\mathrm{C}=\mathrm{O}) \mathrm{CH}_{3}$

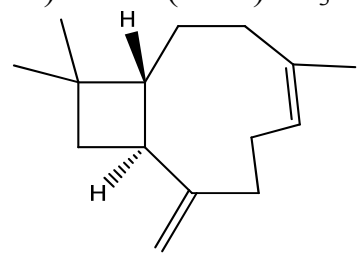

(406)

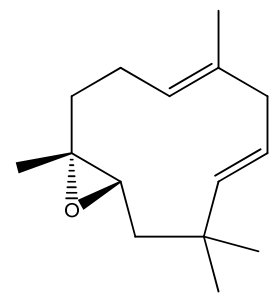

(403)

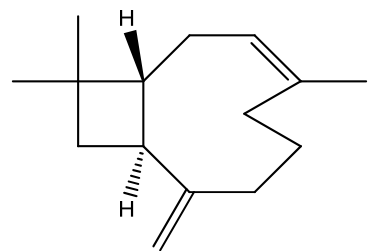

(407)

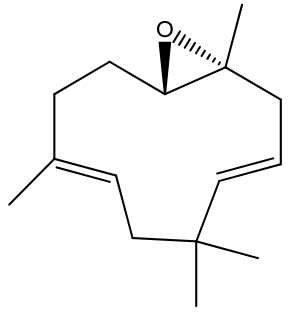

(404)

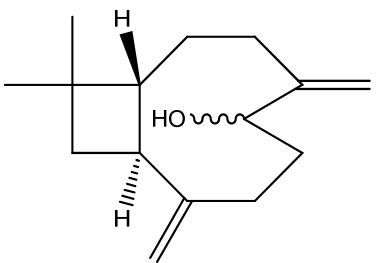

(408) $\alpha-\mathrm{OH}$

(409) $\beta-\mathrm{OH}$

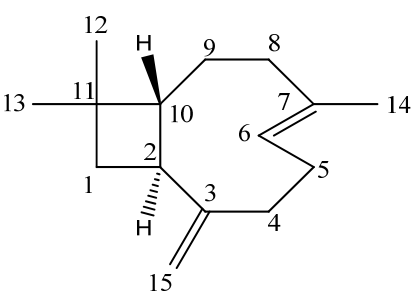

(405)

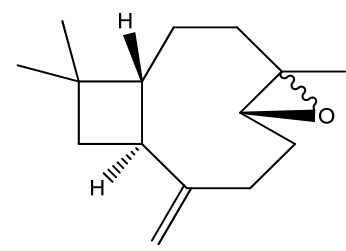

(410) $\beta-\mathrm{C}-\mathrm{O}$

(411) $\alpha-\mathrm{C}-\mathrm{O}$ 


\subsubsection{Bicyclic Sesquiterpenes}

\subsubsection{Eudesmanes and Eremophilanes}

The bicyclic eudesmane sesquiterpenes (Table 34) are thought to be derived from further cyclization of the monocyclic germacranes (Table 31, Section 2.6.2). Eudesmanes are sometimes referred to as selinanes in the older literature and the most abundant eudesmane from $A$. annua is $\beta$ selinene (412) [40,42]. The isolation of the eudesmane allylic hydroperoxide (414) from A. annua is significant, as its structure is suggestive of formation by spontaneous autoxidation of the hydrocarbon precursor selina-4,11-diene (422) [9]. It has been suggested that reduction of the hydroperoxide in 414 would then result in the allylic alcohol group observed in the natural product $5 \alpha$-hydroxy-eudesma4(15),11-diene (413), as shown in Scheme 4 [9].

Scheme 4. Postulated biogenesis of (414) and (413) by spontaneous autoxidation reaction of (422), followed by reduction.

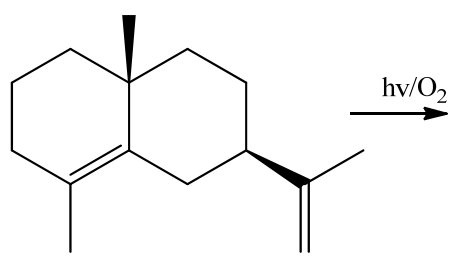

(422)

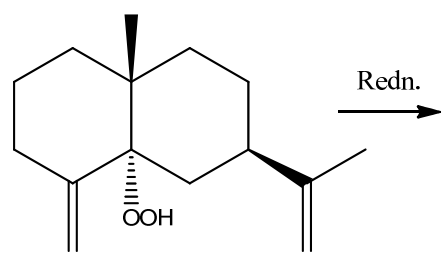

(414)

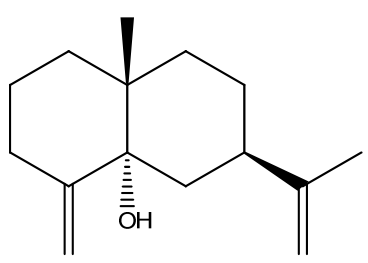

(413)

Table 34. Eudesmane (Selinane) Sesquiterpenoids (Decahydro-1,4 $\alpha$-dimethyl-7-(1methylethyl)-naphthalene, 9CI).

\begin{tabular}{|c|c|c|c|}
\hline Name & Alternative Name(s) & CAS Number & References \\
\hline$\beta$-Selinene (412) & 4(15),11-Eudesmadiene & {$[17066-67-0]$} & $\begin{array}{l}{[19,23,28,30-32,34,} \\
40,42,43,48,113]\end{array}$ \\
\hline $5 \alpha$-Hydroxy-eudesma-4(15),11-diene (413) & 4(15),11-Eudesmadien-5 $\alpha$-ol & & {$[9,97]$} \\
\hline $5 \alpha$-Hydroperoxy-eudesma-4(15),11-diene (414) & & & [9] \\
\hline $1 \beta, 6 \alpha$-Dihydroxy-4(15)-eudesmane (415) & & & [9] \\
\hline $1 \beta$-Hydroxy-4(15),5-eudesmadiene (416) & & & [9] \\
\hline 1 $\beta$-Hydroxy-4(15),7-eudesmadiene (417) & & & [9] \\
\hline$\gamma$-Selinene $(418)$ & $\begin{array}{l}\text { 4(15),7(11)-Eudesmadiene } \\
4(15), 7(11) \text {-Selinadiene }\end{array}$ & {$[515-17-3]$} & {$[45,48]$} \\
\hline$\beta$-Eudesmol (419) & 4(15)-Eudesmen-11-ol & {$[473-15-4]$} & {$[45]$} \\
\hline$\alpha$-Selinene (420) & 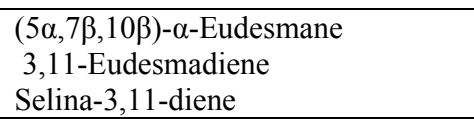 & {$[473-13-2]$} & {$[34,111]$} \\
\hline Kongol (421) & $\begin{array}{l}\text { 11-Eudesmen-4-ol }(4 \alpha, 5 \alpha, 7 \beta, 10 \beta) \\
\text { Selin-11-en-4 } \alpha \text {-ol }\end{array}$ & {$[16641-47-7]$} & {$[19,27]$} \\
\hline Selina-4,11-diene (422) & Eudesma-4,11-diene & {$[17627-30-4]$} & {$[135]$} \\
\hline$\gamma$-Eudesmol (423) & 4-Eudesmen-11-ol & [1209-71-8] & {$[27]$} \\
\hline 10-epi- $\gamma$-Eudesmol (424) & 4-Eudemen-11-ol $(7 \beta, 10 \alpha)$ & [15051-81-7] & {$[27,45]$} \\
\hline Occidentalol (425) & 1,3-Eudesmadien-11-ol & {$[473-17-6]$} & {$[27]$} \\
\hline Occidentalol acetate (426) & & {$[346608-97-7]$} & {$[27]$} \\
\hline Occidol (427) & $\begin{array}{l}\text { 1,2,3,4-Tetrahydro- } \alpha, \alpha-5,8- \\
\text { tetramethyl-2-naphthalenemethanol }\end{array}$ & [5986-36-7] & {$[27]$} \\
\hline Artemisin (428) & & & {$[141]$} \\
\hline$\alpha$-Hydroxysantonin (429) & & & [142] \\
\hline
\end{tabular}


Table 34. Cont.

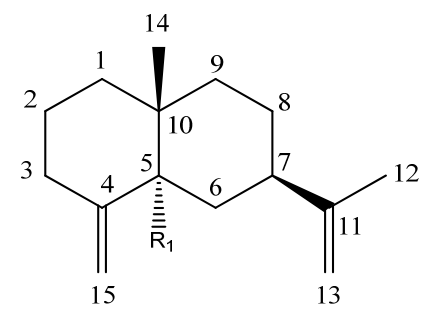

(412) $\mathrm{R}_{1}=\mathrm{H}$

(413) $\mathrm{R}_{1}=\mathrm{OH}$

(414) $\mathrm{R}_{1}=\mathrm{OOH}$<smiles>C=C1CC[C@@H](O)[C@]2(C)CC=C(C(C)C)C[C@H]12</smiles><smiles>[2H][C@@]12C[C@H](C(=C)C)CC[C@@]1([14CH3])CCC=C2C</smiles>

(420)

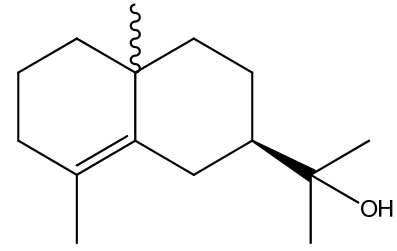

(423) $\beta-\mathrm{Me}$

(424) $\alpha-\mathrm{Me}$

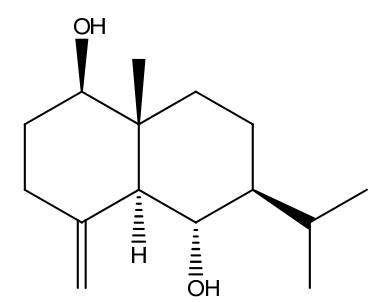

(415)

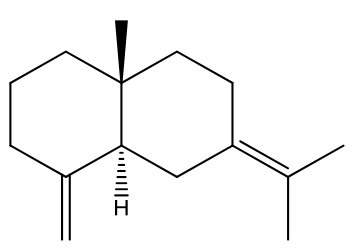

(418)

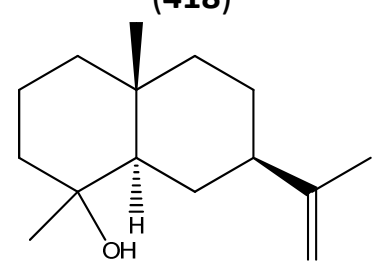

(421)

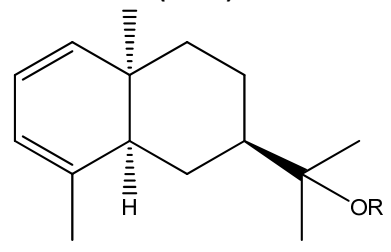

(425) $\mathrm{R}=\mathrm{H}$

(426) $\mathrm{R}=(\mathrm{C}=\mathrm{O}) \mathrm{CH}_{3}$<smiles>[2H][C@H]1C[C@@]2(C)C=CC(=O)C(C)=C2C2OC(=O)[C@]([2H])(C)C21</smiles>

(428) $\mathrm{R}_{1}=\mathrm{OH} ; \mathrm{R}_{2}=\mathrm{H}$

(429) $\mathrm{R}_{1}=\mathrm{H} ; \mathrm{R}_{2}=\mathrm{OH}$<smiles>C=C1CC[C@@H](O)[C@]2(C)CC[C@@H](C(C)C)C=C12</smiles>

(416)

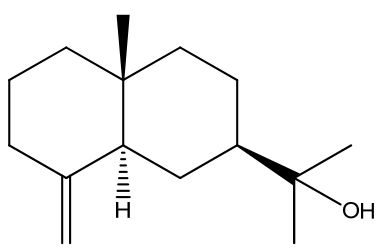<smiles>C=C(C)[C@@H]1CC[C@@]2(C(C)(C)C)CCCC(C)=C2C1</smiles>

(422)<smiles>Cc1ccc(C)c2c1CCC(C(C)(C)O)C2</smiles>

(427)

The eremophilane skeleton (decahydro-1,8a-dimethyl-7-(1-methylethyl)naphthalene, 9CI) is thought to be derived from the eudesmane skeleton by migration of the C-10 methyl group to C-5 [16]. Two eremophilanes: nootkatone (1(10),11-eremophiladiene-2-one [4674-50-4]) (430) [22,43] and valencene (1(10),11-eremophiladiene $(4 \alpha, 5 \alpha, 7 \beta)$ [4630-07-3]) (431) [28] are currently reported from A. annua. The aristolane sesquiterpenoid, $\beta$-gurjunene (1(10)-aristolene [73464-47-8]) (432) [34], is the only example of a 6,11-cycloeremophilane from this species. 


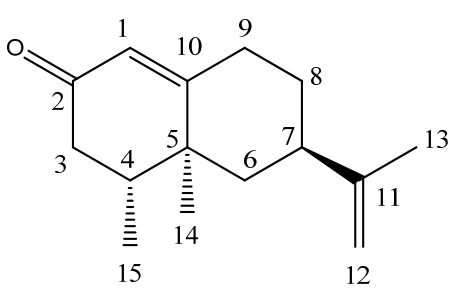

(430)

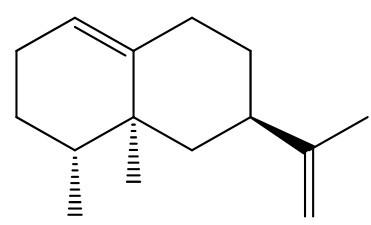

(431)

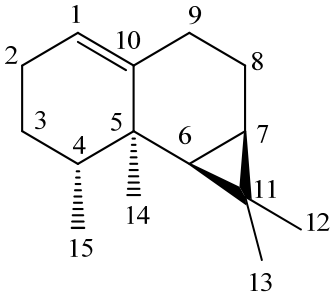

(432)

\subsubsection{Cadinanes, Muurolanes and Amorphanes}

The amorphane/cadinane group of bicyclic sesquiterpenes is by far the largest class of sesquiterpenes found in A. апnиa. Unfortunately, the nomenclature and stereochemistry reported for cadinanes and amorphanes in the literature has sometimes become quite confusing. In this review, the relative stereochemistry at the 1-, 6- and 7-positions is used to define four skeletal types, according to guidelines which are set out in the Dictionary of Natural Products [16]. Thus, in the cadinane skeleton, the decalin ring is trans-fused $(1 \alpha, 6 \beta, 7 \beta)$, while in the muurolane skeleton $(1 \beta, 6 \beta, 7 \beta)$, it is cis-fused. The cadinane and muurolane sesquiterpenes found in $A$. annua have been grouped together in Table 35. Amorphane sesquiterpenes also incorporate a cis-decalin ring junction, but differ from the muurolane sesquiterpenes in their relative stereochemistry at the 7-position. The very large group of amorphane sesquiterpenes from $A$. annua is listed in Table 36. (No representative of the bulgarane sesquiterpenes $(1 \alpha, 6 \beta, 7 \alpha)$, the fourth possible skeleton allowed by this classification scheme, is known from A. annua).

Table 35. Cadinane and Muurolane Sesquiterpenoids (Decahydro-1,6-dimethyl-4-(1methylethyl)-naphthalene, 9CI).

\begin{tabular}{|c|c|c|c|}
\hline Name & Alternative Name(s) & CAS number & References \\
\hline \multicolumn{4}{|l|}{ Cadinanes } \\
\hline Artemisinol (433) & 12-Cadinanol & {$[82890-78-6]$} & {$[143]$} \\
\hline$\delta$-Cadinene (434) & 1(10),4-Cadinadiene & {$[483-76-1]$} & $\begin{array}{l}{[19,23,30,31,} \\
32,40,43,48, \\
51]\end{array}$ \\
\hline 14-Hydroxy- $\delta$-cadinene (435) & & [153408-92-5] & {$[27]$} \\
\hline 4(15),5,11-Cadinatriene (436) & 1-epi-Bicyclosesquiphellandrene & [54274-73-6] & [48] \\
\hline$\alpha$-Cadinene (437) & 4,9-Cadinadiene & [24406-05-1] & {$[111,130]$} \\
\hline$\beta$-Cadinene (438) & 3,9-Cadinadiene & {$[523-47-7]$} & {$[22,66]$} \\
\hline$\gamma$-Cadinene (439) & 4(10),15-Cadinadiene & [39029-41-9] & {$[32,34,40,43]$} \\
\hline$\alpha$-Cadinol (440) & 4-Cadinen-10-ol & {$[481-34-5]$} & {$[19,43,45]$} \\
\hline$\gamma$-Cadinol (441) & $\begin{array}{l}\text { 2-Naphthalenol, 1,2,3,4,4a,7,8,8a-octahydro-2,5- } \\
\text { dimethyl-8-(1-methylethyl)- }\end{array}$ & {$[50895-55-1]$} & {$[45]$} \\
\hline cis-Calamenene (442) & & [72937-55-4] & {$[32,43]$} \\
\hline Cubenol (443) & 4-Cadinen-1-ol & [21284-22-0] & {$[19,43]$} \\
\hline epi-Cubenol (444) & 4-Muurolen-1-ol & [19912-67-5] & [41] \\
\hline \multicolumn{4}{|l|}{ Muurolanes } \\
\hline$\gamma$-Muurolene (445) & 4,10(14)-Muuroladiene & [30021-74-0] & [43] \\
\hline$\delta$-Muurolene (446) & 4(15),10(14)-Muuroladiene & {$[1136-29-4]$} & {$[23]$} \\
\hline 4-Muurolen-10-ol (447) & Cedrelanol & [5937-11-1] & [25] \\
\hline$t$-Muurolol (448) & 4-Muurolen-10-ol $(1 \beta, 6 \beta, 7 \beta, 10 \beta)$ & [19912-62-0] & [19] \\
\hline
\end{tabular}


Table 35. Cont.<smiles>CC1=CC2C(C(C)=CO)CCC(C)C2CC1</smiles>

(433)<smiles>CC1=C[C@@H]2[C@H](CC1)C(C)=CC[C@@H]2C(C)C</smiles>

(437)<smiles>CC1=C[C@H]2[C@@H](C(C)C)CC[C@](C)(O)[C@@H]2CC1</smiles>

(440)<smiles>CC1=CC2C(C(C)C)CCC(C)C2(O)CC1</smiles>

(443)<smiles>C=C1CC[C@H]2C(=C)CC[C@H](C(C)C)[C@H]2C1</smiles>

(446)<smiles>[R]CC1=C[C@@H]2C(=C(C)CC[C@@H]2C(C)C)CC1</smiles>

(434) $\mathrm{R}=\mathrm{H}$

(435) $\mathrm{R}=\mathrm{OH}$<smiles>CC1=CC[C@H]2C(C)=CC[C@H](C(C)C)[C@H]2C1</smiles>

(438)<smiles>CC1=CC[C@H](C(C)C)[C@H]2CC(C)(O)CC[C@H]12</smiles>

(441)<smiles>CC1=C[C@H]2[C@@H](C(C)C)CC[C@@H](C)[C@]2(O)CC1</smiles>

(444)<smiles>CC1=CC2C(C(C)C)CCC(C)(O)C2CC1</smiles>

(447)<smiles>C=C1C=C2C(C(=C)C)CC[C@H](C)[C@H]2CC1</smiles>

(436)<smiles>C=C1CC[C@H](C(C)C)[C@H]2C=C(C)CC[C@]12C</smiles>

(439)<smiles>Cc1ccc2c(c1)[C@H](C(C)C)CC[C@H]2C</smiles>

(442)<smiles>C=C1CC[C@H](C(C)C)[C@]2(C)C=C(C)CC[C@H]12</smiles>

(445)<smiles>CC1=CCC2C(C1)C(C(C)C)CCC2(C)O</smiles>

(448)

Both the synthesis [144] and NMR properties [145,146] of amorphane and cadinane sesquiterpenes from A. annua have been reviewed. Artemisinic acid (473) [105,147,148], arteannuin B (462) $[105,147,149]$ and artemisinin (495) $[105,147,150]$ are the most abundant representatives of this class of natural products and were amongst the first sesquiterpenes to be reported from A. annua. Several of the amorphane sesquiterpenes in Table 36 have since been implicated as biosynthetic precursors to artemisinin (495), which has been classified as a seco-cadinane in Table 37 (the prefix "seco-" indicates that carbon-carbon bond cleavage has occurred - in this case between C-4 and C-5). 
The amorphane sesquiterpene, artemisinic acid (473) (Table 36) was first isolated in 1981 by Prof Tu's group [151]. Its structure was confirmed both by X-ray crystallography $[148,152]$ and by NMR spectroscopy [153]; and subsequently by synthesis [154,155]. Depending on the chemotype of $A$. annua being studied, artemisinic acid (473) can be present at ten times the concentrations of artemisinin (495). For this reason, much research has been undertaken into the chemical conversion of artemisinic acid (473) to artemisinin (495), which can be achieved with an efficiency of greater than $40 \%[156,157]$ (see also Section 4.4 for an application of this conversion to the production of artemisinin). By varying the conditions for the oxidation step, artemisinic acid (473) can be converted to various other sesquiterpenes from A. annua, including: arteannuin B (462) [158, 159], deoxyarteannuin B (477) [160] and epi-deoxyarteannuin B (478) [161,162] (note that deoxyarteannuin B (477) [129,161], epi-deoxyarteannuin (478) [68,158,160,163,164] and 6, 7-dehydroartemisinic acid (476) [165] have all also been obtained independently by chemical synthesis).

Dihydroartemisinic acid (480), which is the 11,13-dihyro analogue of artemisinic acid (473) in Table 36, was first isolated as a natural product several years after artemisinic acid [166,167] and it has also been chemically synthesised [168,169]. It is particularly significant that dihydroartemisinic acid hydroperoxide (481), the tertiary allylic hydroperoxide from dihydroartemisinic acid, has also been isolated as a natural product from A. annua [170]. This has led to the suggestion that dihydroartemisinic acid (480) might be converted to its tertiary hydroperoxide (481) in the living plant by a non-enzymatic process as shown in Scheme 5. This hypothesis has apparently been confirmed by recent in vivo and in vitro experiments [155,185] (see Section 3.3) which also suggested that (481) can undergo further non-enzymatic conversion to (495).

Although both artemisinic acid (473) and dihydroartemisinic acid (480) are the most signifcant amorphane sesquiterpenes from $A$. annua in regard of the biosynthesis of artemisinin (495), several other amorphanes from this species have also been implicated in this process (see Section 3.3). These amorphane sesquiterpenes appear amongst the alphabetical listings in Table 36. Arteannuin A (461) was one of the first sesquiterpenes to be reported from $A$. annua and it has since been synthesized on two occasions [171,172]. The structure of arteannuin B (462) was determined in 1972 by X-ray crystallography [173] in combination with 1D- [174] and 2D- [175] NMR spectroscopy, and it has also been confirmed by chemical reactions [176]. Several syntheses of arteanuin B are reported [158,171,177-179] and arteannuin $C$ [180] is now thought to be identical with arteannuin B [175]. Syntheses have also been reported of arteannuin E (463) [181] and arteannuin F (464) [182] (which is also referred to as artemisilactone) [171].

The structures of arteannuin H (465) [166,183], arteannuin I (466) [166], arteannuin J (467) [166], arteannuin K (468) [166,184], arteannuin L (469) [166,184] and arteannuin M (470) [166,184] were all deduced by 2D-NMR spectroscopy, when they were first described as natural products from $A$. annua. All of these compounds have been reported as metabolites of dihydroartemisinic acid (480) in vivo (Scheme 5) [185], and there is evidence from in vitro studies to support the biogenetic proposal that arteannuin $\mathrm{H}$ (465) might be produced by spontaneous autoxidation reactions involving a secondary allylic hydroperoxide, which is derived from dihydroartemisinic acid (480) as shown in Scheme 5 [183]. The stereochemistry of the 5-hydroxyl group was wrongly assigned when arteannuins $\mathrm{K}$ (468), L (469) and M (470) were first reported as natural products [166]. The correct stereochemistry at the 5-OH group has now been established as $\alpha$ (as drawn) by 2D-NMR studies 
involving derivitization of synthetic arteannuins $\mathrm{K}, \mathrm{L}$ and $\mathrm{M}$ as their Mosher esters [184]; and by chemical synthesis of both natural (-)-arteannuin M [184] and its (+)-enantiomer [186-188]. The structure of the natural product arteannuin O (471), which is epimeric with arteannuin $\mathrm{M}(\mathbf{4 7 0})$ at the 4-position, was confirmed by X-ray crystallography; arteannuin O (471) has also been obtained by a reconstructive synthesis from artemisinin (495) via dihydro-epi-dexoyarteannuin B (485) [184].

Scheme 5. Proposed biogenesis of arteannuin H (465) and other amorphane sesquiterpenes from A. annua via tertiary and allylic secondary hydroperoxides which are derived from spontaneous autoxidation of dihydroartemisinic acid (480)/artemisinic acid (473).
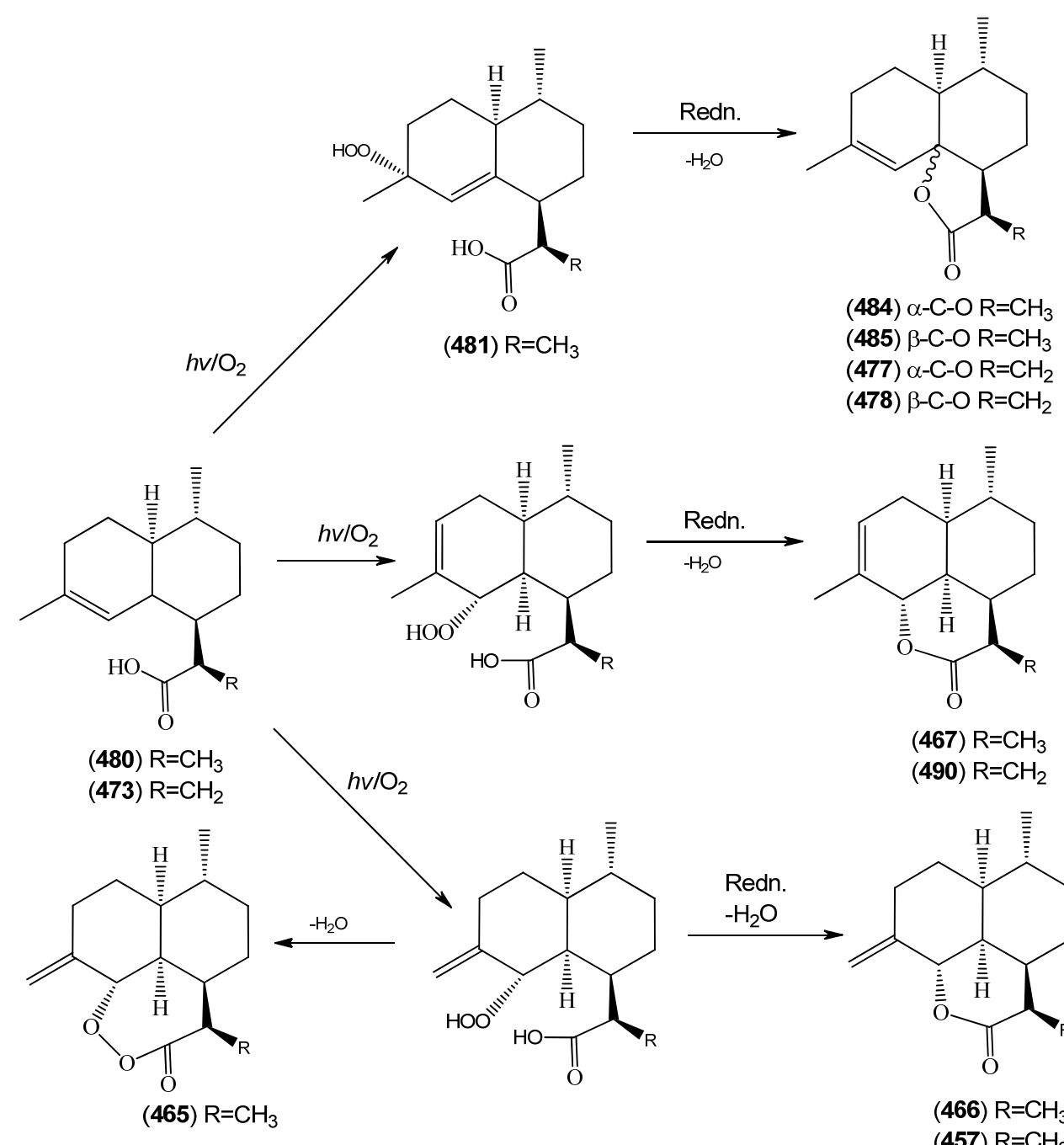

(467) $\mathrm{R}=\mathrm{CH}_{3}$

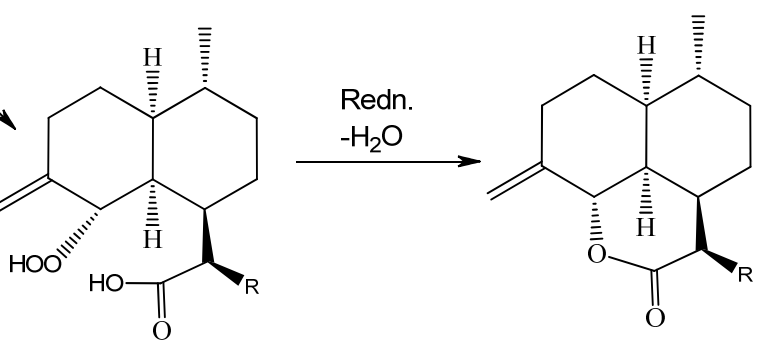

(466) $\mathrm{R}=\mathrm{CH}_{3}$ (457) $\mathrm{R}=\mathrm{CH}_{2}$

All of the five-membered lactones, dihydro-deoxyarteannuin B (484) [129], dihydroarteannuin B (479) $[166,189]$ and dihydro-epi-deoxyarteannuin B (485) [166,189] were also fully characterized by 2D-NMR when first reported as natural products. Dihydro-epi-deoxyarteannuin B (485) has since been obtained by synthesis on several occasions [68,169,190-192] and is probably derived from the allylic

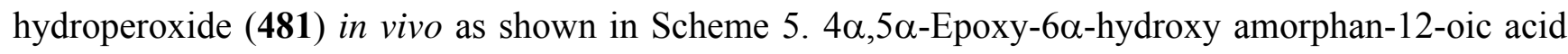
(489) can be regarded as the lactone-ring opened analogue of dihydroarteannuin B (479) [193]; and $\alpha$ epoxyartemisinic acid (487) has also been obtained by synthesis [194]. 
Table 36. Amorphane Sesquiterpenoids (Decahydro-1,6-dimethyl-4-(1-methylethyl)-naphthalene, 9CI).

\begin{tabular}{|c|c|c|c|}
\hline Name & Alternative Name(s) & CAS Number & References \\
\hline 4,7(11)-Amorphadien-12-al (449) & Cadin-4,7(11)-dien-12-al (name ascribed by original authors) & {$[67604-12-0]$} & {$[66]$} \\
\hline 4(15),11-Amorphadien-9-one (450) & $\begin{array}{l}\text { Cadin-4(15),11-dien-9-one (name ascribed by original } \\
\text { authors) }\end{array}$ & {$[159662-31-4]$} & [66] \\
\hline (-)-Amorpha-4,11-diene (451) & $\begin{array}{l}\text { Naphthalene, 1,2,3,4,4a,5,6,8a-octahydro-4,7-dimethyl-1-(1- } \\
\text { methylethenyl)-, }(1 R, 4 R, 4 \mathrm{a} S, 8 \mathrm{a} R) \text { - }\end{array}$ & [92692-39-2] & {$[135,136,196]$} \\
\hline 4-Amorphene-3,7-diol $(3 \alpha, 7 \alpha)(452)$ & & & {$[97]$} \\
\hline $\begin{array}{l}\text { 4-Amorphene-3,7-diol }(3 \alpha, 7 \alpha) \text {, acetate- } \\
\text { (453) }\end{array}$ & $7 \alpha$-Dihydroxyamorph-4-ene 3-acetate & & [9] \\
\hline 4-Amorphen,3,11-diol (454) & $\begin{array}{l}\text { 1-Naphthalenemethanol, 1,2,3,4,4a,5,6,8a-octahydro-6- } \\
\text { hydroxy- } \alpha, \alpha, 4,7 \text {-tetramethyl- }\end{array}$ & {$[159662-32-5]$} & {$[66]$} \\
\hline $\begin{array}{l}\text { 4-Amorphen,3,11-diol 3-(2- } \\
\text { methylpropanoyl) (455) }\end{array}$ & 3-Isobutylcadin-4-en-11-ol & {$[159662-30-3]$} & {$[66]$} \\
\hline Amorph-4-en-7-ol (456) & $\begin{array}{l}\text { 1-Naphthalenol, 1,2,3,4,4a,5,6,8a-octahydro-4,7-dimethyl-1- } \\
\text { (1-methylethyl)-, }(1 R, 4 R, 4 \mathrm{a} S, 8 \mathrm{a} R) \text { - }\end{array}$ & {$[140385-39-3]$} & {$[134]$} \\
\hline Annulide (457) & $\begin{array}{l}\text { Naphtho[1,8-bc]pyran-2(3H)-one, decahydro-6-methyl-3,9- } \\
\text { bis(methylene)-[3aR-3a } \alpha, 6 \alpha, 6 \mathrm{a} \alpha, 9 \mathrm{a} \beta, 9 \mathrm{~b} \alpha) \text { - }\end{array}$ & {$[103739-95-3]$} & $\begin{array}{l}{[97,128,129,182,} \\
197]\end{array}$ \\
\hline trans-Arteannuic alcohol (458) & $\begin{array}{l}\text { Artemisinic alcohol } \\
\text { Amorpha-4,11-dien-12-ol } \\
\text { 1-Naphthaleneethanol, } 1,2,3,4,4 \mathrm{a}, 5,6,8 \mathrm{a}-\text { octahydro-4,7- } \\
\text { dimethyl- } \beta \text {-methylene-, }(1 R, 4 R, 4 \mathrm{a} S, 8 \mathrm{a} R)\end{array}$ & {$[125184-95-4]$} & {$[27,32,43,135,196]$} \\
\hline cis-Arteannuic alcohol (459) & 4,11(13)-Cadinadien-12-ol & {$[147648-62-2]$} & {$[27,32,43]$} \\
\hline Artemisinic aldehyde (460) & $\begin{array}{l}\text { 1-Naphthaleneacetaldehyde, } 1,2,3,4,4 \mathrm{a}, 5,6,8 \mathrm{a} \text {-octahydro-4,7- } \\
\text { dimethyl- } \alpha \text {-methylene-, }(1 R, 4 R, 4 \mathrm{a} S, 8 \mathrm{a} R) \text { - }\end{array}$ & {$[125276-60-0]$} & {$[135,196]$} \\
\hline Arteannuin A (461) & $\begin{array}{l}\text { Artemisinin I } \\
\text { Qinghaosu I }\end{array}$ & {$[82442-48-6]$} & $\begin{array}{l}{[56,171,172,} \\
198,199]\end{array}$ \\
\hline Arteannuin B (462) & $\begin{array}{l}\text { Qing Hau Sau II } \\
\text { Arteannuin C }\end{array}$ & {$[50906-56-4]$} & $\begin{array}{l}{[15,20,25,55,59,69} \\
96,105,147,149 \\
153]\end{array}$ \\
\hline Arteannuin E (463) & $\begin{array}{l}\text { Qinghaosu V } \\
\text { 4-Hydroxy-11(13)-amorphen-12,5-olide; } 4 \beta, 5 \alpha\end{array}$ & {$[82003-84-7]$} & $\begin{array}{l}{[56,132,147,150} \\
176,180,182,199, \\
205]\end{array}$ \\
\hline Arteannuin F (464) & $\begin{array}{l}\text { Artemisilactone } \\
\text { 4-Hydroxy-11(13)-amorphen-12,5-olide } 4 \alpha, 5 \alpha\end{array}$ & [92691-97-9] & {$[56,99,132,147,150$} \\
\hline Arteannuin H (465) & $\begin{array}{l}\text { Naphtho[1,8-cd]-1,2-dioxepin-3(4H)-one, decahydro-4,7- } \\
\text { dimethyl-10-methylene- }(4 R, 4 \mathrm{a} R, 7 R, 7 \mathrm{a} S, 10 \mathrm{a} S, 10 \mathrm{~b} S) \text { - }\end{array}$ & [207446-83-1] & {$[166,183]$} \\
\hline Arteannuin I (466) & $\begin{array}{l}\text { Naphtho[1,8-bc]pyran-2(3H)-one, decahydro-3,6-dimethyl-9- } \\
\text { methylene- }(3 R, 3 \mathrm{a} R, 6 R, 6 \mathrm{a} S, 9 \mathrm{a} S, 9 \mathrm{~b} S) \text { - }\end{array}$ & {$[207446-85-3]$} & {$[129,166]$} \\
\hline Arteannuin J (467) & $\begin{array}{l}\text { Naphtho[1,8-bc]pyran-2(3H)-one, 3a,4,5,6,6a,7,9a,9b- } \\
\text { octahydro-3,6,9-trimethyl }(3 R, 3 \mathrm{a} R, 6 R, 6 \mathrm{a} S .9 \mathrm{a} S, 9 \mathrm{~b} S) \text { - } \\
\end{array}$ & {$[207446-87-5]$} & {$[129,166,201]$} \\
\hline Arteannuin K (468) & $\begin{array}{l}\text { 2H-Naphtho[8a,1-b]furan-2-one, 3,3a,4,5,6,6a,7,10- } \\
\text { octahydro-10-hydroxy-3,6,9-trimethyl-, } \\
(3 R, 3 \mathrm{a} S, 6 R, 6 \mathrm{a} S, 10 R, 10 \mathrm{a} S) \text { - }\end{array}$ & {$[207446-88-6]$} & {$[166,206]$} \\
\hline Arteannuin L (469) & $\begin{array}{l}\text { 2H-Naphtho[8a,1-b]furan-2-one, decahydro-10-hydroxy-3,6- } \\
\text { dimethyl-9-methylene-, }(3 R, 3 \mathrm{a} S, 6 R, 6 \mathrm{a} S, 10 R, 10 \mathrm{a} S) \text { - }\end{array}$ & {$[207446-89-7]$} & {$[166,206]$} \\
\hline Arteannuin M (470) & $\begin{array}{l}\text { 2H-Naphtho[8a,1-b]furan-2-one, decahydro-9,10-dihydroxy- } \\
\text { 3,6,9-trimethyl-, (3R,3aS,6R,6aS,9R,10R,10aS)- }\end{array}$ & {$[207446-90-0]$} & {$[166,186,187]$} \\
\hline Arteannuin N (472) & 5-Oxo-3-amorphen-12-oic acid & {$[207446-92-2]$} & {$[166]$} \\
\hline Arteannuin O (471) & $\begin{array}{l}\text { 2H-Naphtho[8a,1-b]furan-2-one, decahydro-9,10-dihydroxy- } \\
\text { 3,6,9-trimethyl-, }(3 R, 3 \mathrm{a} S, 6 R, 6 \mathrm{a} S, 9 S, 10 R, 10 \mathrm{a} S) \text { - }\end{array}$ & [382600-19-3] & [184] \\
\hline Artemisinic acid (473) & $\begin{array}{l}\text { Arteannuic acid } \\
\text { 4,11(13)-Amorphadien-12-oic acid } \\
\text { Qing Hau acid }\end{array}$ & {$[80286-58-4]$} & $\begin{array}{l}{[15,20,31,55,56,59} \\
61,65,69,105,143, \\
147,148,153,160, \\
163,164,184,198 \\
200,204,207-211]\end{array}$ \\
\hline Artemisinic acid, methyl ester (474) & $\begin{array}{l}\text { Methyl artemisinate } \\
4,11(13) \text {-Amorphadien-12-oic acid methyl ester }\end{array}$ & [82869-24-7] & {$[97,143,166,212]$} \\
\hline Artemisinin B (475) & $\begin{array}{l}\text { 1-Naphthaleneacetic acid, } 1,2,3,4,4 \mathrm{a}, 5,8,8 \mathrm{a} \text {-octahydro- } 8,8 \mathrm{a}- \\
\text { dihydroxy-4,7-dimethyl- } \alpha \text {-methylene-, }(1 S, 4 R, 4 \mathrm{a} S, 8 R, 8 \mathrm{a} R) \text { - }\end{array}$ & [145941-07-7] & {$[65]$} \\
\hline 6,7-Dehydroartemisinic acid (476) & $\begin{array}{l}\text { 4,11(13)-Amorphadien-12-oic acid } \\
\text { 6,7-didhydro } \\
\text { 4,6,11(13)-Cadinatrien-12-oic acid }\end{array}$ & {$[120193-24-0]$} & {$[160,163,213]$} \\
\hline Deoxyarteannuin B (477) & Deoxyisoartemisinin C & {$[128301-55-3]$} & $\begin{array}{l}{[97,129,163,175} \\
201,214,215]\end{array}$ \\
\hline
\end{tabular}


Table 36. Cont.

\begin{tabular}{|c|c|c|c|}
\hline epi-Deoxyarteannuin B (478) & Deoxyisoartemisinin B & [84237-06-9] & $\begin{array}{l}{[68,96,97,129,158,} \\
160,163,164,197]\end{array}$ \\
\hline Dihydroarteannuin B (479) & $\begin{array}{l}\text { 3H-Oxireno[7,8]naphtho[8a,1-b]furan-3-one, } \\
\text { decahydro-4,7,9a-trimethyl- [1aR- } \\
(1 \mathrm{a} \alpha, 1 \mathrm{bR}, 4 \beta, 4 \mathrm{a} \beta, 7 \beta, 7 \mathrm{a} \beta, 9 \mathrm{a} \alpha)] \text { - }\end{array}$ & {$[64390-16-5]$} & {$[166]$} \\
\hline $11 R$-(-)-Dihydroartemisinic acid (480) & 4,11(13)-Amorphadien-12-oic acid (11R,13-dihydro) & [85031-59-0] & $\begin{array}{l}{[20,32,43,135,166,} \\
167,216]\end{array}$ \\
\hline Dihydroartemisinic acid hydroperoxide (481) & 4-Hydroxyperoxy-5-amorphen-12-oic acid, $4 \alpha, 11 R$ & {$[85031-60-3]$} & {$[167,170,185]$} \\
\hline Dihydroartemisinic alcohol (482) & $\begin{array}{l}\text { 1-Naphthaleneethanol, 1,2,3,4,4a,5,6,8a-octahydro- } \\
\alpha, 4,7 \text {-trimethyl-, }(1 R, 4 R, 4 \mathrm{a} S, 8 \mathrm{a} S) \text { - }\end{array}$ & {$[855425-50-2]$} & {$[135]$} \\
\hline Dihydroartemisinic aldehyde (483) & $\begin{array}{l}\text { 1-Naphthaleneacetaldehyde, } 1,2,3,4,4 \mathrm{a}, 5,6,8 \mathrm{a}- \\
\text { octahydro- } \alpha, 4,7 \text {-trimethyl-, }(1 R, 4 R, 4 \mathrm{a} S, 8 \mathrm{a} S) \text { - }\end{array}$ & {$[855425-51-3]$} & {$[135]$} \\
\hline Dihydro-deoxyarteannuin B (484) & $\begin{array}{l}\text { 2H-Naphtho[8a,1-b]furan-2-one, } 3,3 \mathrm{a}, 4,5,6,6 \mathrm{a}, 7,8- \\
\text { octahydro-3,6,9-trimethyl- }[3 R-(3 \alpha, 3 \mathrm{a} \beta, 6 \beta, 6 \mathrm{a} \beta, 9 \mathrm{a} R)]-\end{array}$ & {$[89956-69-4]$} & {$[129]$} \\
\hline Dihydro-epi-deoxyarteannuin B (485) & 4-Cadinen-12,6-olide $(6 \beta, 10 \beta \mathrm{H}, 12 \alpha \mathrm{H})$ & [104196-16-9] & {$[60,68,129,166]$} \\
\hline Dihydroxycadinanolide (486) & & & {$[217]$} \\
\hline$\alpha$-Epoxyartemisinic acid (487) & $\alpha$-Epoxy-arteannuic acid & & {$[129,160,194]$} \\
\hline$\alpha$-Epoxy-dihydroartemisinic (488) & & & [9] \\
\hline $\begin{array}{l}4 \alpha, 5 \alpha \text {-Epoxy-6 } \alpha \text {-hydroxy amorphan-12-oic } \\
\text { acid (489) }\end{array}$ & & & [9] \\
\hline Isoannulide (490) & $\begin{array}{l}\text { Naphtho[1,8-bc]pyran-2(3H)-one, 3a,4,5,6,6a,7,9a,9b- } \\
\text { octahydro-6,9-dimethyl-3-methylene-, [3aR- } \\
(3 \mathrm{a} \alpha, 6 \alpha, 6 \mathrm{a} \alpha, 9 \mathrm{a} \beta, 9 \mathrm{~b} \alpha)] \text { - }\end{array}$ & {$[103739-94-2]$} & $\begin{array}{l}{[97,128,129,182,} \\
197]\end{array}$ \\
\hline $\begin{array}{l}\text { 2-Naphthalenol, decahydro-1-methyl-6- } \\
\text { methylene-4-(1-methylethenyl)- (491) }\end{array}$ & & {$[159662-33-6]$} & {$[66]$} \\
\hline Verboccidentene (492) & Amorpha-4,7(11)-diene & {$[79982-58-4]$} & {$[134]$} \\
\hline
\end{tabular}<smiles>CC1=C[C@]2(C)/C(=C(/C)C=O)CC[C@@H](C)[C@H]2CC1</smiles>

(449)<smiles>C=C1CC[C@]2(C)[C@H](C)C(=O)C[C@@H](C(=C)C)[C@]2(C)C1</smiles>

(450)<smiles>C=C(C)[C@H]1CC[C@@H](C)[C@H]2CCC(C)=C[C@H]12</smiles>

(451)<smiles>CC1=C[C@@]2(C(C)(C)Br)C(C)(C)[C@H](C)CC[C@@]2(C)C[C@H]1P</smiles>

(452) $\mathrm{R}_{1}=\mathrm{OH} ; \mathrm{R}_{2}=\mathrm{OH} ; \mathrm{R}_{3}=\mathrm{H}$

(453) $\mathrm{R}_{1}=\mathrm{O}-(\mathrm{C}=\mathrm{O}) \mathrm{CH}_{3} ; \mathrm{R}_{2}=\mathrm{OH} ; \mathrm{R}_{3}=\mathrm{H}$

(454) $\mathrm{R}_{1}=\mathrm{OH} ; \mathrm{R}_{2}=\mathrm{H} ; \mathrm{R}_{3}=\mathrm{OH}$

(455) $\mathrm{R}_{1}=\mathrm{O}-(\mathrm{C}=\mathrm{O}) \mathrm{CH}\left(\mathrm{CH}_{3}\right)_{2} ; \mathrm{R}_{2}=\mathrm{H} ; \mathrm{R}_{3}=\mathrm{OH}$

(456) $\mathrm{R}_{1}=\mathrm{H} ; \mathrm{R}_{2}=\mathrm{OH} ; \mathrm{R}_{3}=\mathrm{H}$<smiles>C=C1C(=O)O[C@@H]2C(=C)CC[C@H]3[C@@H](C)CC[C@@H]1[C@@]32C</smiles>

(457)<smiles>C=C1C(=O)O[C@H]2C(C)(C)CC[C@]3(C)[C@@H](C)CC[C@H](C)[C@@]123</smiles>

(463) $\beta-C-O$

(464) $\alpha-C-O$<smiles>[R]C(=C)[C@H]1CC[C@H](C)[C@@H]2CCC(C)=C[C@H]12</smiles>

(458) $\alpha-\mathrm{H} ; \mathrm{R}=\mathrm{CH}_{2} \mathrm{OH}$ (459) $\beta-\mathrm{H} ; \mathrm{R}=\mathrm{CH}_{2} \mathrm{OH}$ (460) $\alpha-\mathrm{H} ; \mathrm{R}=\mathrm{CHO}$<smiles>C=C1C[C@@H](C)[C@]23COC(=O)[C@H](C)[C@@]2(C)C(=C)CC[C@@H]13</smiles>

(465)<smiles>CC1=CC[C@H]2[C@@H](C)CC[C@@H]3C(=O)O[C@H]1[C@@]32C</smiles>

(461)<smiles>C=C1CC[C@H]2C(C)CC[C@]3(C)[C@@H](C)C(=O)O[C@H]1[C@]23C</smiles>

(466)<smiles>C=C1C(=O)O[C@@]23[C@@H]1CC[C@@H](C)[C@@]2(C)CC[C@@]1(C)O[C@@H]31</smiles>

(462)<smiles>CC1=CC[C@H]2C(C)CC[C@]3(C)[C@@H](C)C(=O)O[C@H]1[C@@]23C</smiles>

(467) 
Table 36. Cont.

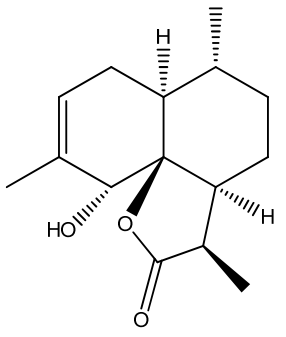

(468)

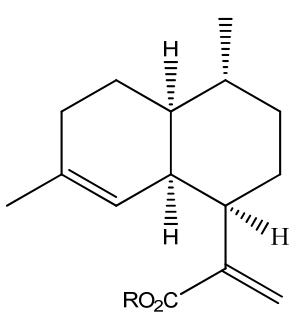

(473) $\mathrm{R}=\mathrm{H}$

(474) $\mathrm{R}=\mathrm{Me}$

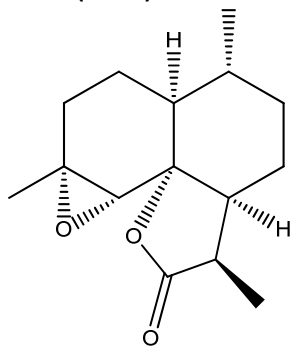

(479)

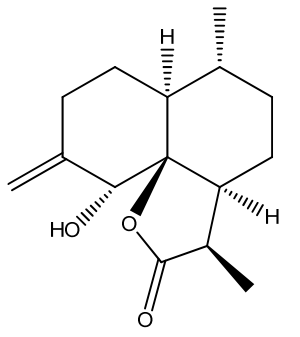

(469)

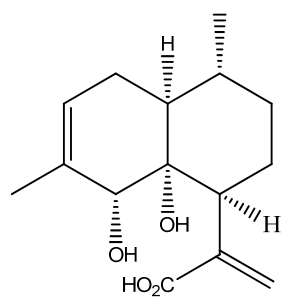

(475)

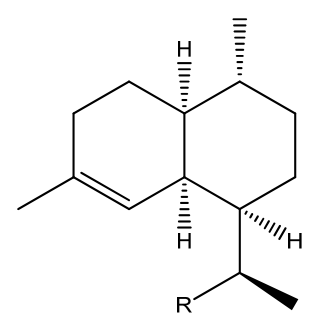

(480) $\mathrm{R}=\mathrm{CO}_{2} \mathrm{H}$

(482) $\mathrm{R}=\mathrm{CH}_{2} \mathrm{OH}$

(483) $\mathrm{R}=\mathrm{CHO}$

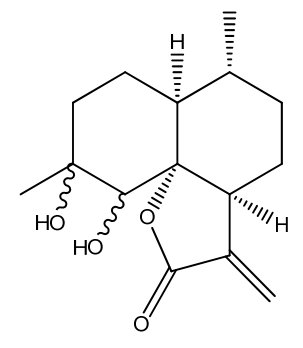

(486)

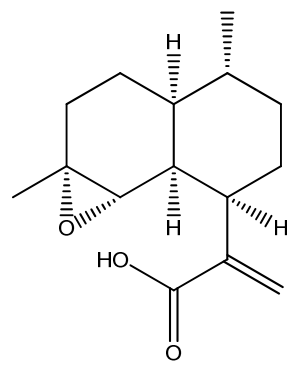

(487)

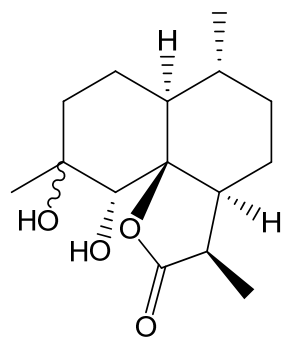

(470) $\alpha-C-O$

(471) $\beta-C-O$<smiles>C=C(C(=O)O)C1=C2C=C(C)CC[C@H]2C(C)CC1</smiles>

(476)

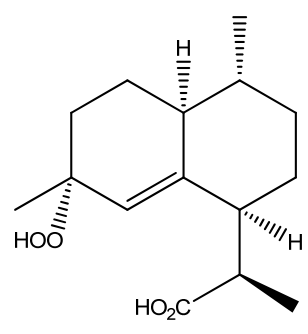

(481)<smiles>CC1=CC[C@H]2[C@@H](C)CC[C@H]([C@H](C)C(=O)O)[C@]2(C)C1=O</smiles>

(472)

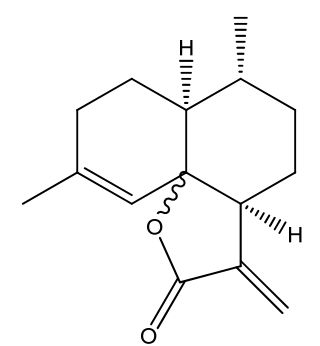

(477) $\alpha-C-O$

(478) $\beta-C-O$

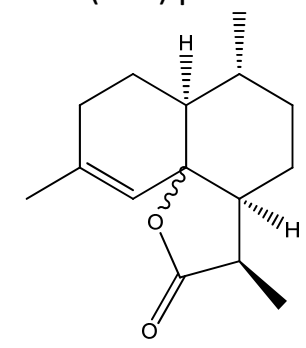

(484) $\alpha-C-O$

(485) $\beta-C-O$

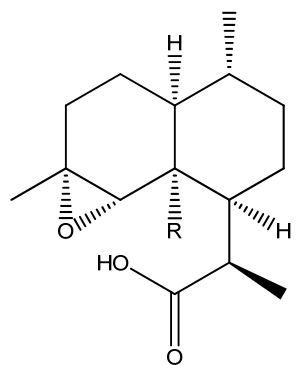

(488) $\mathrm{R}=\mathrm{H}$

(489) $\mathrm{R}=\mathrm{OH}$<smiles>C=C1C[C@]23[C@@H](C)CC[C@H](C)[C@@]2(C)CC=C(C)[C@@H]3OC1=O</smiles>

(490)<smiles>C=C1CC[C@H]2[C@@H](C)C(O)C[C@](C)(C(=C)C)[C@]2(C)C1</smiles>

(491)<smiles>CC1=C[C@H]2C(=C(C)C)CC[C@H](C)[C@]2(C)CC1</smiles>

(492) 
It is interesting to note that nine of the structures reported in Tables 36 and 38 occur in both their 11,13-dihydro and 11,13-dehydro forms. These nine pairs are listed in Table 37.

Table 37. Amorphane and seco-amorphane natural products from A. annua which occur as both 11,13-dihydro and 11,13-dehydro forms.

\begin{tabular}{|l|l|}
\hline 11,13-Dihydro form & $\mathbf{1 1 , 1 3 - D e h y d r o ~ f o r m ~}$ \\
\hline Dihydroartemisinic acid (480) & Artemisinic acid (473) \\
\hline Dihydroarteannuin B(479) & Arteannuin B (462) \\
\hline Dihydro-epi-deoxyarteannuin B(485) & epi-Deoxyarteannuin B (478) \\
\hline Dihydro-deoxyarteannuin B (484) & Deoxyarteannuin B (477) \\
\hline$\alpha$-Epoxy-dihydroartemisinic acid (488) & $\alpha$-Epoxy-artemisinic acid (487) \\
\hline Dihydro-seco-cadinane (493) & seco-Cadinane (494) \\
\hline Arteannuin I (466) & Annulide (457) \\
\hline Arteannuin J (467) & Isoannulide (490) \\
\hline Artemisinin (495) & Artemisitene (497) \\
\hline
\end{tabular}

Feeding labelled dihydroartemisinic acid (480) to A. annua resulted in sixteen labelled amorphane and cadinane sesquiterpenes [185], which included all nine of the 11,13-dihydro forms in the "pairs" in Table 37 (*The complete list of metabolites of (480) is: artemisinin (495), dihydroarteannuin B (479), dihydro-epi-deoxyarteannuin $B(\mathbf{4 8 5})$, arteannuin $M(\mathbf{4 7 0})$, the seco-cadinane $(\mathbf{4 9 3})$, the tertiary hydroperoxide of dihydroartemisinic acid (481), dihydro-deoxyarteannuin B (484), deoxyartemisinin (499), arteannuin K (468), arteannuin L (469), arteannuin H (465), arteannuin I (466), arteannuin J (467) and $\alpha$-epoxy-dihydroartemisinic acid (488).

* The most significant products from this feeding study were dihydroarteannuin B (479), dihydroepi-deoxyarteannuin B (485) and the dihydro seco-cadinane (493). The pattern of transformations of dihydroartemisinic acid (480) which was observed in vivo very closely paralleled the spontaneous autoxidation chemistry for dihydroartemisinic acid which had previously been demonstrated in vitro [193,218]. This has lead to the proposal that the main metabolic route to all three of these metabolites and artemisinin (495) in A. annua involves the spontaneous autoxidation of dihydroartemisinic acid (480) and the subsequent chemical reactions of the derived tertiary allylic hydroperoxide (481), as is shown in Scheme 6.

Scheme 6. The most dominant products from metabolism of dihydroartemisinic acid (480) in vivo in A. annua plants.

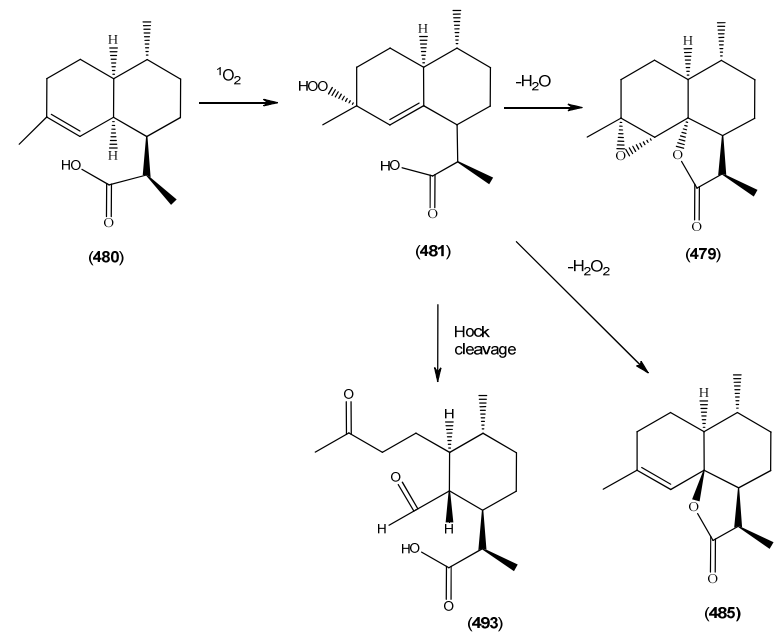


When labeled artemisinic acid (473), the 11,13-dehydro analogue of dihydroartemisinic acid (480), was fed to intact A. annua plants, slightly fewer labeled metabolites were isolated [155]. However, all seven metabolites from this experiment are also known as natural products from A. annua and six of the seven feature in the pairs of metabolites discussed in Table 37. The most abundant metabolite from feeding artemisinic acid (473) was arteannuin B (462), followed by epi-deoxyarteannuin B (478) and the seco-cadinane (494) as shown in Scheme 7 (the remaining four metabolites are: annulide (457), isoannulide (490), deoxyarteannuin B (477) and artemisinic acid methyl ester (474), which were all isolated in trace amounts.

It is intriguing to note that there are exact structural homologies between six of the seven highly oxygenated 11,13-dehydro sesquiterpenes which have been isolated as metabolites of artemisinic acid (473) and a subset of the sixteen 11,13-dihydro metabolites which were obtained in the preceding study with dihydroartemisinic acid (480) (see Table 37). Clearly, the in vivo transformations of artemisinic acid (473) closely parallel those of its 11,13-dihydro analogue, dihydroartemisinic acid (480), as is shown by Schemes 5, 6 and 7. (However, note that in the case of artemisinic acid (473), no allylic hydroperoxide analogous to $\mathbf{( 4 8 1 )}$ in Scheme 6 was isolated in vivo as a natural product, and its existence as an intermediate in Scheme 7 must therefore be inferred. Such an allylic hydroperoxide can, however, be produced in the laboratory by chemical reactions with ${ }^{1} \mathrm{O}_{2}$ and it is known to undergo in vitro several of the transformations which are depicted in vivo in Scheme 7).

Scheme 7. The most dominant products from metbolism of artemisinic acid (473) in vivo in A. annua plants.

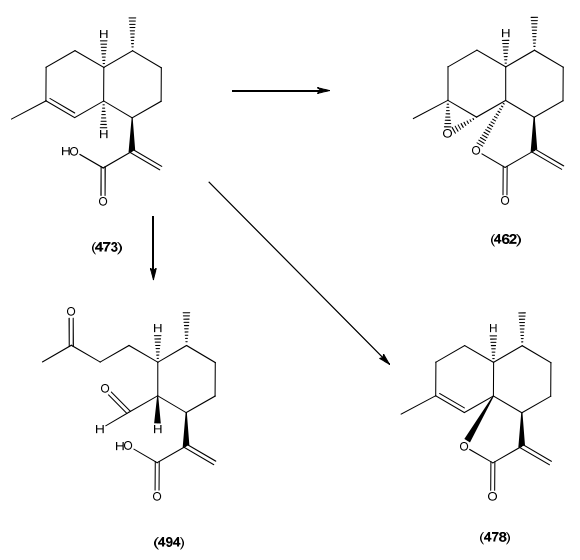

It seems likely therefore that similar mechanisms are operative in the metabolism of both dihydroartemisinic acid (480) and artemisinic acid (473). These biological transformations have been proposed to involve spontaneous autoxidation of the $\Delta^{4,5}$ double bond in $(\mathbf{4 7 3}) /(\mathbf{4 8 0})$ and subsequent rearrangements of the resultant allylic hydroperoxides $[155,185]$. In addition, feeding experiments with both labeled precursors appear to show that artemisinic acid (473) and dihydroartemisinic acid (480) are NOT mutually interconvertible; rather, each is the committed precursor to the two large families of highly oxygenated 11,13-dehydro and 11,13-dihydro sesquiterpene metabolites which are known from this species (see, for example, the nine pairs of compounds in Table 37). This observation fits well with the reported occurrence of two chemical races of $A$. annua: a low-yielding-artemisinin chemotype, which is rich in artemisinic acid; and a high-yielding-artemisinin chemotype, which also contains significant quantities of dihydroartemisinic acid, as discussed in Section 4.1. 


\subsubsection{Seco-Cadinanes}

Artemisinin (495) is a seco-cadinane sesquiterpene, which was first isolated from A. annua in 1972. The unusual endoperoxide group in artemisinin has been confirmed by a variety of means [219-226] and the absolute stereochemistry of artemisinin has been established by X-ray crystallography [227]. Many total [171,228-235] and partial syntheses [236-239] of artemisinin have been reported and the various synthetic strategies have been reviewed [144]. Artemisitene (497), the 11,13-dehydro analogue of artemisinin, is present in A. annua at much lower levels than artemisinin (typically concentrations in the order of $0.01 \%$, as compared with $1 \%$ ) [240], although artemisitene can be obtained readily by chemical transformations of artemisinin [165,213,241,242]; and a partial synthesis of artemisitene from artemisinic acid (473) has also been reported [243].

Artemisinin (495) is believed to be localized primarily within the glandular trichomes of $A$. annua, which are loosely attached to the leaf surface [244]. Perhaps because of this highly accessible location, it has been claimed that artemisnin can be extracted in $97 \%$ yield simply by dipping a leaf in chloroform for 5 seconds!

Table 38. Seco-Cadinane, nor-Cadinane and abeo-Cadinane Sesquiterpenoids.

\begin{tabular}{|c|c|c|c|}
\hline Name & Alternative Name(s) & $\begin{array}{l}\text { CAS } \\
\text { Number }\end{array}$ & References \\
\hline 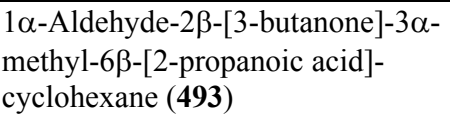 & & & [9] \\
\hline 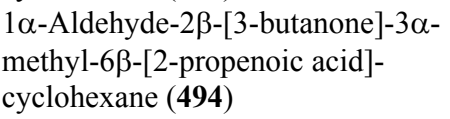 & 4,5-Dioxo-4,5-seco-11(13)cadinen-12-oic acid & & {$[9,217]$} \\
\hline Artemisinin (495) & $\begin{array}{l}\text { Arteannuin } \\
\text { Qinghaosu } \\
\text { Octahydro-3,6,9-trimethyl-3,12-epoxy-12H- } \\
\text { pyrano[4,3-j]-1,2,benzodioxepin-10(3H)-one }\end{array}$ & $\begin{array}{l}{[63968-} \\
64-9]\end{array}$ & $\begin{array}{l}{[4,5,15,20,34,55,56,59,69,82,91,} \\
95,96,98,105,147,150,156,171,198, \\
200,203,204,211,213,214,215,220, \\
230,231,234,236,239,245-252]\end{array}$ \\
\hline Arteannuin G (496) & & & $\begin{array}{l}{[9,56,132,147,150,176,180,182,} \\
199,205,253]\end{array}$ \\
\hline Artemisitene (497) & Artemisinin, 11,13-didehydro & $\begin{array}{l}{[101020-} \\
89-7]\end{array}$ & {$[25,55,149,200,213,250]$} \\
\hline Arteannuin D (498) & $\begin{array}{l}3 \alpha \text {-Hydroxy-deoxyartemisinin } \\
\text { Qinghaosu IV } \\
\text { Artemisinin IV }\end{array}$ & $\begin{array}{l}{[82003-} \\
85-8]\end{array}$ & {$[15,56]$} \\
\hline Deoxyartemisinin (499) & $\begin{array}{l}\text { Deoxyarteannuin } \\
\text { Qing Hau Sau III } \\
\text { Artemisinin III } \\
\text { Octahydro-3,6,9-trimethyl-10 } \alpha \mathrm{H}-9,10 \mathrm{~b} \text {-epoxy- } \\
\text { pyrano[4,32-jk][2]benzoxepin-2(3H)-one }\end{array}$ & $\begin{array}{l}{[72826-} \\
63-2]\end{array}$ & {$[56,59,60,105,132,145,147,169,229,254]$} \\
\hline $\begin{array}{l}3 \alpha \text {-Hydroxy- } 4 \alpha, 5 \alpha \text {-epoxy-7-oxo- } \\
(8[7 \rightarrow 6] \text {-abeo-amorphane }(\mathbf{5 0 0})\end{array}$ & & & \\
\hline Norannuic acid (501) & & $\begin{array}{l}{[152135-} \\
59-6]\end{array}$ & {$[199]$} \\
\hline Norannuic acid formyl ester (502) & & & [9] \\
\hline $\begin{array}{l}\text { 15-nor-10-Hydroxy-oplopan-4-oic } \\
\text { acid (503) }\end{array}$ & & & [9] \\
\hline 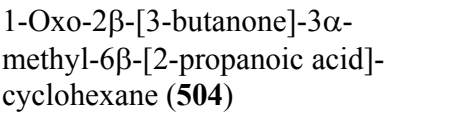 & & & [9] \\
\hline 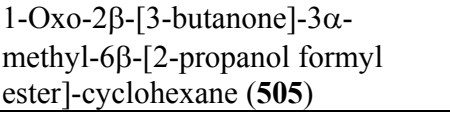 & & & {$[9,218]$} \\
\hline
\end{tabular}


Table 38. Cont.

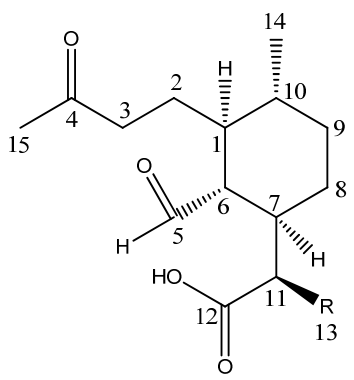

(493) $\mathrm{R}=\mathrm{CH}_{3}$

(494) $\mathrm{R}=\mathrm{CH}_{2}$

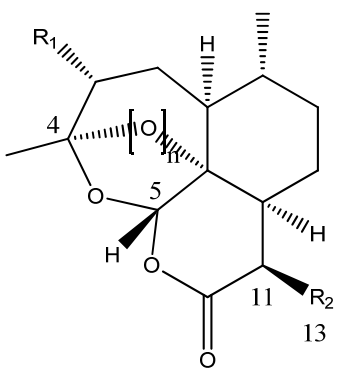

(495) $\mathrm{R}_{1}=\mathrm{H} ; \mathrm{R}_{2}=\mathrm{Me} ; \mathrm{n}=2$

(497) $\mathrm{R}_{1}=\mathrm{H} ; \mathrm{R}_{2}=\mathrm{CH}_{2} ; \mathrm{n}=2$

(498) $\mathrm{R}_{1}=\mathrm{OH} ; \mathrm{R}_{2}=\mathrm{Me} ; \mathrm{n}=1$

(499) $\mathrm{R}_{1}=\mathrm{H} ; \mathrm{R}_{2}=\mathrm{Me} ; \mathrm{n}=1$

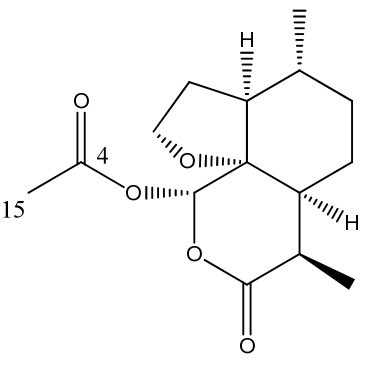

(496)

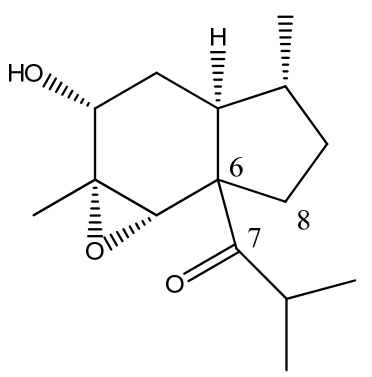

(500)

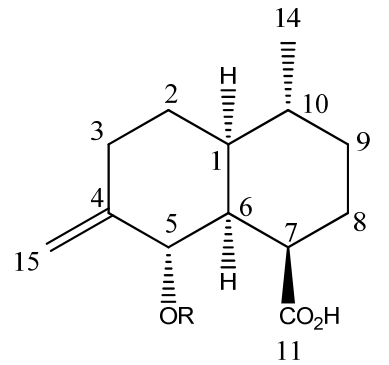

(501) $\mathrm{R}=\mathrm{H}$

(502) $\mathrm{R}=\mathrm{CHO}$<smiles>[R]C(C)[C@H]1CC[C@@H](C)[C@H](CCC(C)=O)C1=O</smiles>

(504) $\mathrm{R}=\mathrm{CO}_{2} \mathrm{H}$

(505) $\mathrm{R}=\mathrm{CH}_{2} \mathrm{OCHO}$

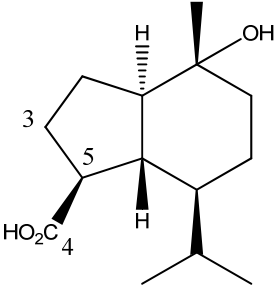

(503)

Deoxyartemisinin (499) is some 100-300 times less potent than artemisinin (495) as an antimalarial drug, which demonstrates that the peroxy linkage in artemisinin is indeed necessary for its biological activity. Several syntheses of deoxyartemisinin have been reported [171,229,236,254,255]. Fully assigned 2D-NMR data are available for artemisinin (495) [221], the seco-cadinane 493 [9] and deoxyartemisinin (499) [165].

The formyl ester in nor-amorphane $\mathbf{5 0 2}$ is thought to have been derived from the carbon at the 12position of an amorphane precursor by oxidative rearrangements. This group has been lost altogether, presumably as the result of ester hydrolysis, in the bis-nor-amorphane sesquiterpene, norannuic acid 501 [66,199]. Similarly, the formyl group in 1-oxo-2 $\beta$-[3-butanone]-3 $\alpha$-methyl-6 $\beta$-[2-propanol formyl ester]-cyclohexane (505) [218] is probably also derived from oxidative rearrangements, this time deriving from the 5-position of an appropriate bicyclic precursor (the related seco-cadinane natural product $\mathbf{5 0 4}$ has also been reported from the in vitro autoxidation of dihydroartemisinic acid in organic solution) [193]. It seems likely that the ethyl substituent in artemisinin G (496) might be derived from the 4- and 15-positions of a conventional amorphane precursor. 
The novel carbon skeleton of compound $\mathbf{5 0 0}$ is thought to be derived from the amorphane skeleton by migration of C-8 from C-7 to C-6 (i.e., compound $\mathbf{5 0 0}$ is an $8(7 \rightarrow 6)$ abeo amorphane), which results in a contraction of the B ring from six atoms to five. Similarly, the unusual carbon skeleton of 503 might also have arisen from an amorphane precursor, in which the A ring has been contracted from six to five atoms, as a result of carbon-carbon bond migration of C-3 from C-4 to C-5 [9].

\subsubsection{Guaianes}

Guaianes (Table 39) are bicyclic sesquiterpenes which contain fused 5- and 7-membered rings. Guaianes are often found together with eudesmanes (which contain two fused 6-membered rings - see Table 34) and may be derived by an alternative cyclization of the same germacrane precursor which gives rise to eudesmanes.

Table 39. Guaiane Sesquiterpenoids (Decahydro-1,4-dimethyl-7-(1-methylethyl)azulene, 9CI).

\begin{tabular}{|c|c|c|c|}
\hline Name & Alternative Name(s) & CAS Number & References \\
\hline$\alpha$-Guaiene (506) & $1(5), 11$-Guaiadiene & {$[3691-12-1]$} & {$[28,36]$} \\
\hline$\beta$-Guaiene (507) & $1(5), 7(11)$-Guaiadiene & {$[88-84-6]$} & {$[32]$} \\
\hline$\gamma$-Gurjunene (508) & $5,11-$-Guaiadiene & {$[22567-17-5]$} & {$[31,34]$} \\
\hline Guaiazulene (509) & 2,4 -Dimethyl-7-(1-methylethyl)azulene & {$[492-45-5]$} & {$[24]$} \\
\hline
\end{tabular}

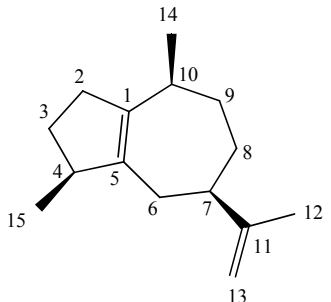

(506)

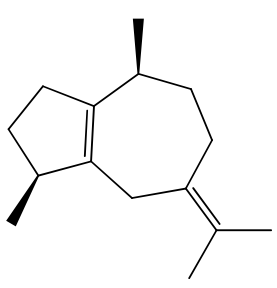

(507)

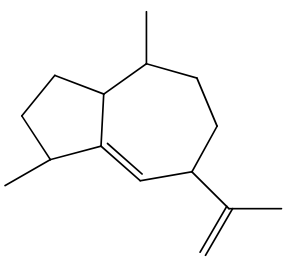

(508)

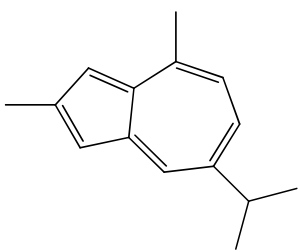

(509)

Aromadendrane sesquiterpenes (Table 40) are 6,11-cycloguaianes, in which an additional cyclopropyl ring has been formed by further cyclization of a guaiane precursor. The unusual metabolite, nortaylorione (15-nor-1,10-seco-1(5)-aromadendrene-4,10-dione [163128-16-3]) (519) [257], might be viewed as the product of oxidative rearrangements of such an aromadendrane precursor. The cubebane sesquiterpenoids (octahydro-3,7-dimethyl-4-(1-methylethyl)-1H-cyclopenta[1,3]-cyclopropa-[1,2]-benzene, 9CI): $\alpha$-cubebene (3-cubebene [17699-14-8]) (520) [51] and $\beta$ cubebene [4(15)-cubebene [13744-15-5], (521)] [19,38,51,66], are also representatives of guaianes which have undergone a further cyclization, with the cyclopropyl ring now being formed between positions 1- and 6-. $\alpha$-Guaiane (506) is the most abundant guaiane sesquiterpene in A. annua [22], whilst spathulenol (515) is the most common aromadendrane [41] (both can reach levels up to 5\% of the essential oil). 
Table 40. Aromadendrane Sesquiterpenoids (Decahydro-1,1,4,7-tetramethyl-1Hcycloprop[e]azulene. 9CI).

\begin{tabular}{|c|c|c|c|}
\hline Name & Alternative Name(s) & CAS Number & References \\
\hline$\alpha$-Aromadendrene (510) & $\begin{array}{l}\text { allo-Aromadendrene } \\
\text { 10(14)-Aromadendrene }\end{array}$ & $\begin{array}{l}{[25246-27-9]} \\
{[14682-34-9]}\end{array}$ & {$[23,40,43]$} \\
\hline$\alpha$-Gurjunene (511) & 4-Aromadendrene & [489-40-7] & [48] \\
\hline Globulol (512) & $(1 \alpha, 4 \alpha, 5 \beta, 6 \alpha, 7 \alpha, 10 \alpha)$-10-Aromadendranol & [489-41-8] & {$[19,28,34]$} \\
\hline epi-Globulol (513) & $\begin{array}{l}\text { 1H-Cycloprop[e]azulen-4-ol, decahydro-1,1,4,7- } \\
\text { tetramethyl-, }(1 \mathrm{a} R, 4 S, 4 \mathrm{a} R, 7 R, 7 \mathrm{a} S, 7 \mathrm{~b} S)-\end{array}$ & [88728-58-9] & [34] \\
\hline Ledol (514) & 10-Aromadendrol $(1 \beta, 4 \alpha, 5 \beta, 6 \beta, 7 \beta, 10 \alpha)$ & {$[577-27-5]$} & {$[28]$} \\
\hline (-)-Spathulenol (515) & 10(14)-Aromadendren-4-ol & $\begin{array}{l}{[77171-55-2]} \\
{[6750-60-3]}\end{array}$ & $\begin{array}{l}{[19,27,31,32,} \\
41,43,45]\end{array}$ \\
\hline $\begin{array}{l}\text { Cycloprop[7,8]azuleno[3a,4 } \\
\text {-b]oxirene, decahydro- } \\
\text { 1,4a,7,7-tetramethyl-, } \\
(1 R, 6 \mathrm{a} R, 7 \mathrm{a} R, 7 \mathrm{~b} S)-(\mathbf{5 1 6})\end{array}$ & & [199983-75-0] & {$[34]$} \\
\hline $\begin{array}{l}\text { Aromadendrene epoxide } \\
(\mathbf{5 1 7})\end{array}$ & $\begin{array}{l}\text { Isoaromadendrene epoxide } \\
\text { 10(14)-Aromadendrene } 10 \beta, 14 \text {-epoxide }\end{array}$ & $\begin{array}{l}{[85710-39-0]} \\
{[499134-59-7]}\end{array}$ & {$[23,34]$} \\
\hline Cyclocolorenone (518) & 4-Aromadendren-3-one & {$[489-45-2]$} & [45] \\
\hline
\end{tabular}

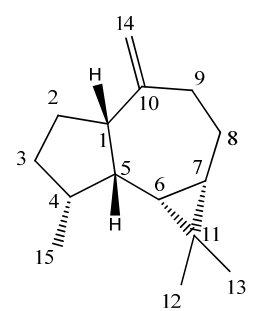

(510)<smiles>C=C1CC[C@@H]2[C@@H]([C@H]3[C@@](C)(O)CC[C@@]13C)C2(C)C</smiles>

(515)<smiles>CC1=C2C(CC1=O)C(C)CCC1C2C1(C)C</smiles>

(518)<smiles>CC1=C2C(C)CCC2C2C(C)CCC12</smiles>

(511)

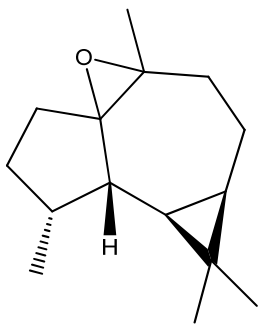

(516)

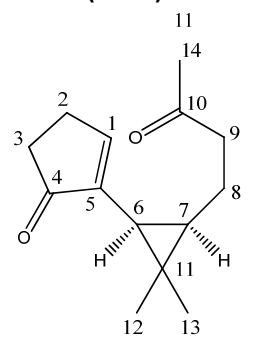

(519)

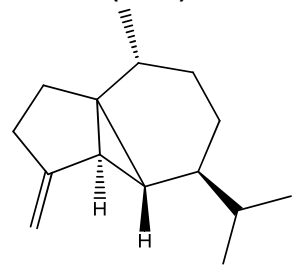

(521)

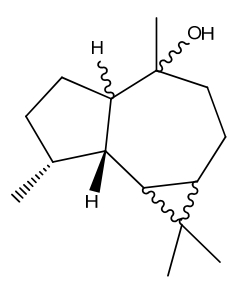

(512) $1 \alpha-\mathrm{H} ; 6 \alpha ; 7 \alpha ; 10 \alpha-\mathrm{OH}$ (513) $1 \alpha-\mathrm{H} ; 6 \alpha ; 7 \alpha ; 10 \beta-\mathrm{OH}$

(514) $1 \beta-\mathrm{H} ; 6 \beta ; 7 \beta ; 10 \alpha-\mathrm{OH}$<smiles>CC1CCC2C1C1C(CCC3(CO3)C1(C)C)C2(C)C</smiles>

(517)<smiles></smiles>

(520) 


\subsubsection{Tricyclic Sesquiterpenes}

Several tricyclic sesquiterpenes are known from $A$. annua, although none have been reported in very significant quantities. These include $\alpha$-longipinene (522) (3-longipinene [5989-08-2]) [22,66], $\beta$ longipinene (523) ([41432-70-6]) [27] and trans-longipinocarveol (524) ([889109-69-7]) [23], which are representatives of the longipinane (2,6,6,9-tetramethyltricyclo[5.4.4.0 ${ }^{2,8}$ ]undecane, 9CI) skeleton. Longifolene (junipene [475-20-7]) (525) [28] is a longifolane sesquiterpenoid (decahydro-4,8,8,9tetramethyl-1,4-methanoazulene, 9CI).

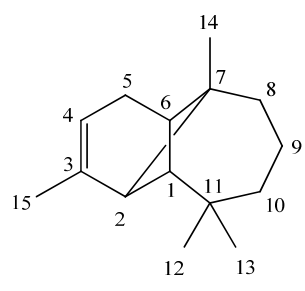

(522)

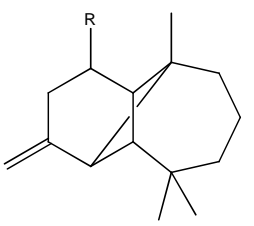

(523) $\mathrm{R}=\mathrm{H}$

(524) $\mathrm{R}=\mathrm{OH}$

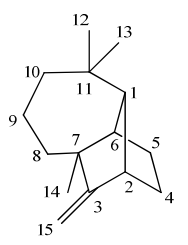

(525)

The acorane (1,8-dimethyl-4-(1-methylethyl)spiro[4.5]decane, 9CI) and chamigrane (11,5,9tetramethylspiro[5,5] undecane, 9CI) sesquiterpenoids: $\beta$-acorenol (3-acoren-11-ol [28400-11-5]) (526) [19] and $\beta$-chamigrene (2,7(14)-chamigradiene [18431-82-8]) (527) [19] are also included here.

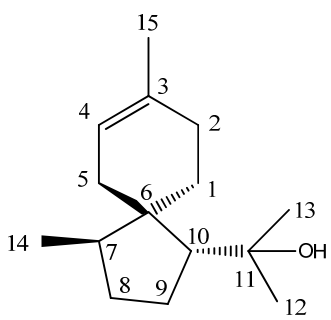

(526)

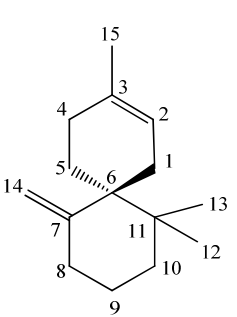

(527)

The largest group of tricyclic sesquiterpenes to be described rom A. annua is the cedranes (Table 41). A cDNA clone encoding epi-cedrol synthase has been shown to catalyze the formation of the oxygenated sesquiterpene epi-cedrol from FPP (378) [258,259]. Trace amounts of the sesquiterpene hydrocarbons $\alpha$-cedrene, $\beta$-cedrene, (E)- $\beta$-farnesene, $\alpha$-acoradiene and $(E)$ - $\beta$-bisabolene were also produced by the operation of this enzyme [258]. The structure of $3 \alpha, 15$-dihydroxycedrane (534) from A. annua has been rigorously determined both by $2 \mathrm{D}-\mathrm{NMR}$ and by synthesis from (+)- $\beta$-cedrene [9].

Table 41. Cedrane Sesquiterpenoids (Octahydro-3,6,8,8-tetramethyl-1H-3 $\alpha$-7-methanoazulene).

\begin{tabular}{|c|c|c|c|}
\hline Name & Alternative Name(s) & CAS Number & References \\
\hline Cedrol (528) & $\begin{array}{l}\text { 3-Cedranol } \\
\text { Cedran-8-ol } \\
\text { 6-Isocedrol } \\
\text { epi-Cedrol }\end{array}$ & {$[77-53-2][19903-73-2]$} & {$[19,27,32,43,45,48]$} \\
\hline Cedryl acetate (529) & 3-Cedranol acetate & [77-54-3] & [27] \\
\hline Cedra-8(15)-en-9 $\alpha$-ol (530) & $\begin{array}{l}\beta \text {-Cedren-9-ol } \\
\text { Cedrenol }\end{array}$ & $\begin{array}{l}{[13567-41-4]} \\
{[28231-03-0]}\end{array}$ & {$[27,43]$} \\
\hline Cedra- $8(15)$-en- $9 \alpha$-ol acetate $(\mathbf{5 3 1})$ & & {$[65082-66-8]$} & {$[27,32,43]$} \\
\hline 3-Cedren-12-ol (532) & & [18319-35-2] & [27] \\
\hline Cedra-8-en-13-ol, acetate $\mathbf{( 5 3 3 )}$ & & [18319-34-1] & {$[27]$} \\
\hline $3 \alpha, 15$-Dihydroxy cedrane $\mathbf{( 5 3 4 )}$ & & & [9] \\
\hline
\end{tabular}




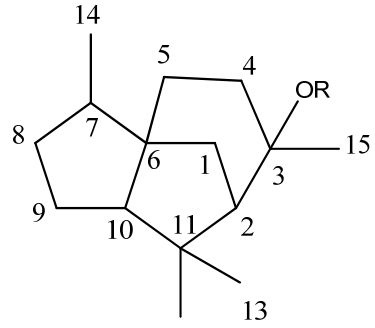

12

(528) $\mathrm{R}=\mathrm{H}$

(529) $\mathrm{R}=(\mathrm{C}=\mathrm{O}) \mathrm{CH}_{3}$

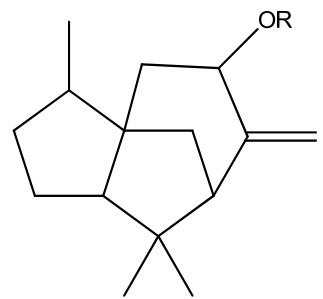

(530) $\mathrm{R}=\mathrm{H}$

(531) $\mathrm{R}=(\mathrm{C}=\mathrm{O}) \mathrm{CH}_{3}$

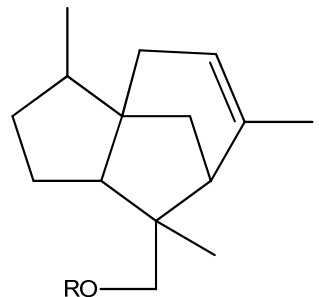

(532) $\mathrm{R}=\mathrm{H}$

(533) $\mathrm{R}=(\mathrm{C}=\mathrm{O}) \mathrm{CH}_{3}$

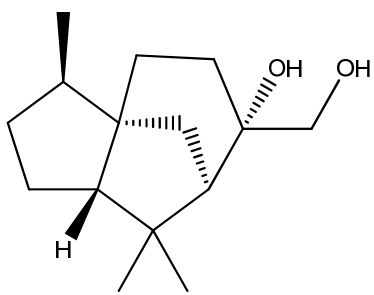

(534)

Other tricyclic sesquiterpenes from A. annua belong to the silphinane (decahydro-1,4,4,5a-tetramethylcyclopenta[c]-pentalene); isocomane (dehydro-1,3 $\alpha, 4,5$-tetramethylcyclopenta[c]pentalene); $\alpha$ santalane (2,3-dimethyl-2-(4-methyl-pentyl)tricycle[2.2.1.0 $\left.0^{2,6}\right]$-heptane); copaane (1,3-dimethyl-8-(1methylethyl)tricyclo[4.4.4.4 $\left.4^{2,7}\right]$ decane, 9CI); bourbonane (decahydro-3a,6-dimethyl-1-(1-methylethyl)cyclobuta[1,3:3,4]-dicyclopentene, 9CI); and $\alpha$-trans-bergamotol classes of sesquiterpenoid. These include: silphinene (1-silphinene [74284-57-4]) (535) [27], $\alpha$-isocomene (isocomene [65372-78-3]) (536) [27], $\beta$-isocomene (3(13)-isocomene [74311-15-2]) (537) [27], (Z)- $\alpha$-santalol ( $\alpha$-santal-10en-12-ol [115-71-9]) (538) [19], $\alpha$-copaene(3-copaene [3856-25-5]) (539) [19, 22-24, 31, 43, 45, 48, 50, 66], $\beta$-copaen-4 $\alpha$-ol (tricyclo[4.4.0.0 $0^{2,7}$ decan-4-ol, 1-methyl-3-methylene-8-(1-methylethyl)-, $(1 R, 2 R, 4 S, 6 S, 7 S, 8 S)-[124753-76-0])(540)[43], \alpha-y l a n g e n e ~([14912-44-8])(541)[25,30,40,113], \beta-$ bourbonene (4(15)-bourbonene [5208-59-3]) (542) [45], $\alpha$-bergamentol [88034-74-6]) (543) [27, 32, 43], trans- $\alpha$-bergamotyl acetate ([87978-33-4]) (544) [27, 43], trans- $\alpha$-bergamotyl acetic anhydride ([960148-87-2]) (545) [32], $\alpha$-neoclovene ([4545-68-0]) (546) [41,50], (-)-neoclovene-(II) [56684-969] (547) [46], neoisolongifolene [79982-57-3] (548) [48] and 4,4,8-trimethyltricyclo[6.3.1.0 $0^{(1,5)}$ ]dodecane-2,9-diol ([372968-04-2]) (549) [20].

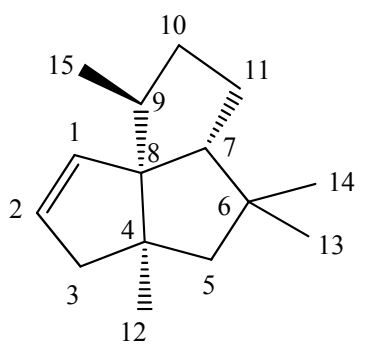

(535)

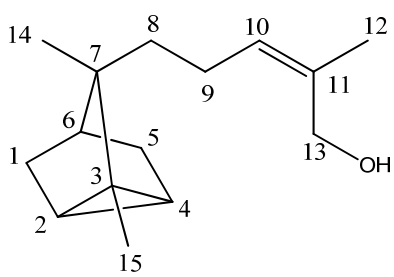

(538)

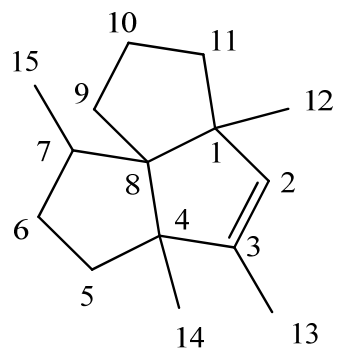

(536)

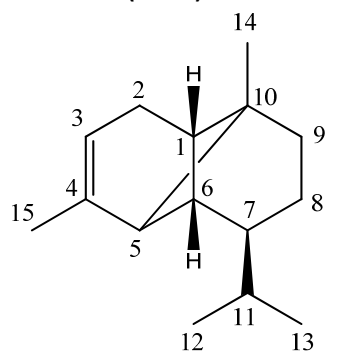

(539)

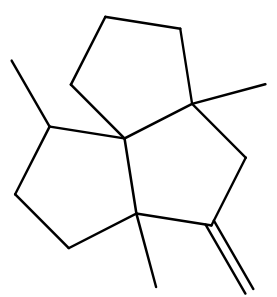

(537)

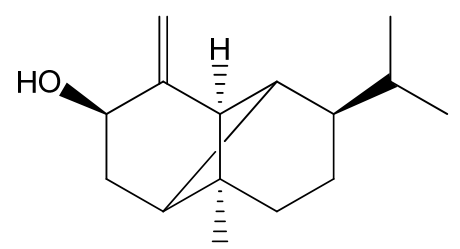

(540) 


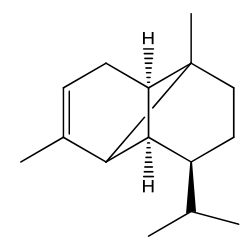

(541)

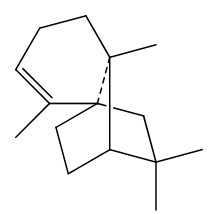

(546)

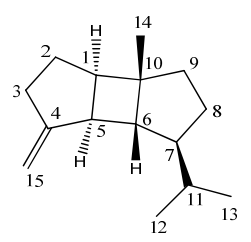

(542)

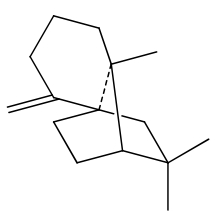

(547)

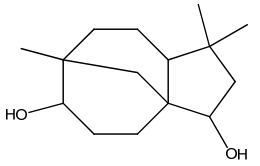

(549)

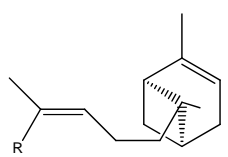

(543) $\mathrm{R}=\mathrm{CH}_{2} \mathrm{OH}$

(544) $\mathrm{R}=\mathrm{CH}_{2} \mathrm{O}-(\mathrm{C}=\mathrm{O}) \mathrm{CH}_{3}$

(545) $\mathrm{R}=(\mathrm{C}=\mathrm{O})-\mathrm{O}-(\mathrm{C}=\mathrm{O}) \mathrm{CH}_{3}$

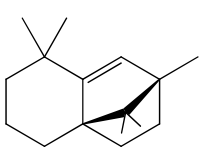

(548)

\subsection{Higher Terpenoids}

\subsubsection{Diterpenes}

The structure of the diterpene phytene-1-ol-2-hydroperoxide (553) $[9,260]$ was wrongly assigned as phytene-1,2-diol (552), when it was first described as a natural product from A. annua [261]. Structural revision was made on the basis of studies of the photo-oxygenation of commercially-available phytol, which produced both phytene-1,2-diol (552) (in racemic form), as well as its 2-hydroperoxy analogue (553) [260]. Both phytol (550) itself and an authentic sample of phytene-1,2-diol (552) were subsequently obtained as natural products from the seeds of A. annua [9]. Natural phytol is expected to have the $7 R, 11 R$ absolute configuration [16], and natural phytene-1,2-diol (552) was therefore assigned as being a mixture of epimers at the 2-position on the basis of its NMR spectra and on the assumption that the configuration at the 7- and 11- positions of (552) remained fixed, as in phytol. The observance of epimers is most easily explained if both the hydroperoxide (553) and alcohol (552) are products of the spontaneous autoxidation of phytol (550), occurring within the tissues of A. annua plants as is shown in Scheme 8.

Scheme 8. Proposed formation of phytene-1-ol-2-hydroperoxide (553) by spontaneous autoxidation of phytol (550) and subsequent homolysis/reduction of 553 to phytene-1,2diol (552).

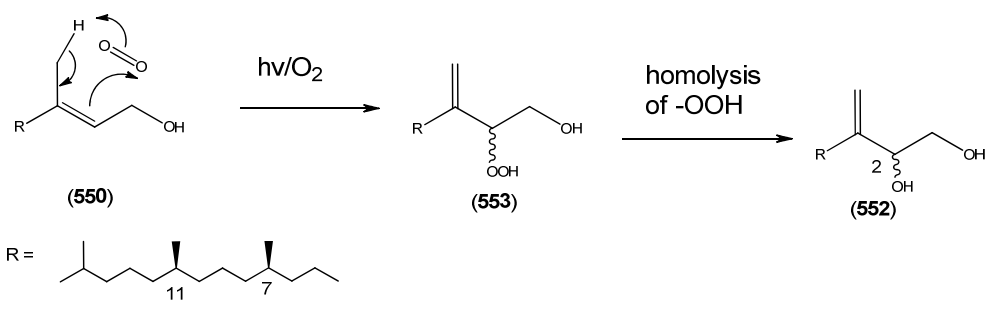


Table 42. Phytane Diterpenoids (2,6,10,14-Tetramethylhexadecane).

\begin{tabular}{|l|l|l|l|}
\hline Name & Alternative Name(s) & CAS Number & References \\
\hline Phytol (550) & 2-Phyten-1-ol $(2 E, 7 R, 11 R)$ & {$[150-86-7]$} & {$[27, \quad 31,43$,} \\
& & & $45]$ \\
\hline Isophytol (551) & 1-Phyten-3-ol & {$[505-32-8]$} & {$[27]$} \\
& $3,7,11,15-$ Tetramethyl-1-hexadecen-3-ol & & {$[9,260,261]$} \\
\hline Phytene-1,2-diol (552) & $3(20)$-Phytene-1,2-diol (7R,11R) & & {$[9,260,261]$} \\
\hline Phytene-1-ol-2-hydroperoxide (553) & & {$[2437-936]$} & {$[20]$} \\
\hline (2E)-Hexadecene (554) & $3,7,11,15-$-Tetramethylhexadec-2-ene & {$[532426-78-1]$} & \\
\hline Phytone (555) & Hexahydrofarnesyl acetone & {$[502-69-2]$} & {$[23]$} \\
& $6,10,14-$-Trimethyl-2-pentadecanone & \\
\hline
\end{tabular}<smiles>CC(=CCO)CCC[C@@H](C)CCC[C@@H](C)CCCC(C)C</smiles>

(550)<smiles>C=CC(C)(O)CCCC(C)CCCC(C)CCCC(C)C</smiles>

(551)<smiles>C=C(CCC[C@@H](C)CCC[C@H](C)CCCC(C)C)[C@H](O)CO</smiles>

(552) $\mathrm{R}=\mathrm{H}$

(553) $\mathrm{R}=\mathrm{OH}$<smiles>CC=C(C)CCCC(C)CCCC(C)CCCC(C)C</smiles>

(554)<smiles>CC(=O)CCC[C@H](C)CCC[C@H](C)CCCC(C)C</smiles>

(555)

A handful of cyclic diterpenes are also known from A. annua, including 13-epi-manool (8(17),14labdadien-13-ol [1438-62-6]) (556) [43], 8(14),15-isopimaradiene ([1686-56-2]) (557) [32] and abscisic acid ([21293-29-8]) (558) [262].

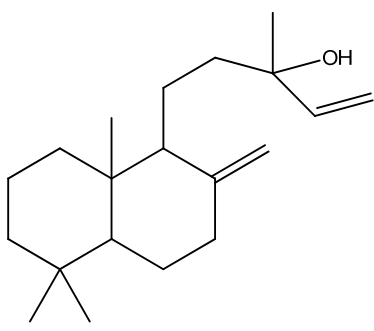

(556)<smiles>C=CC1(C)C=C2CCC3C(C)(C)CCCC3(C)C2CC1</smiles>

(557)<smiles>CC1=CC(=O)CC(C)(C)C1(O)/C=C/C(C)=C/C(=O)O</smiles>

(558)

\subsubsection{Triterpenes and Sterols}

The most abundant sterols from A. annua are stigmasterol (570) and sitosterol (568) [96], which are ubiquitous components of plant cell membranes. Squalene synthase (SQS) is the enzyme which catalyses the first committed step in the pathway leading from FPP (378) to triterpenes and phytosterols, such as these (Table 43). The SQS gene and cDNA have been successfully cloned and sequenced from A. annua on several occasions [263-265]. Much of the interest in SQS stems from its position at a key point in terpenoid biosynthesis, in which FPP (378) branches either to triterpenes or sesquiterpenes. Thus, it is possible that suppression of SQS expression [267] could be used to enhance 
the biosynthesis of artemisinin (495), which is a product of the alternative sesquiterpene pathway from FPP (378) [268].

A $\beta$-amyrin synthase, responsible for cyclization of squalene to the tritepene skeleton, has also been obtained from A. annua. It was possible to produce the triterpene $\beta$-amyrin (559) in significant amounts when this enzyme was engineered into Saccharomyces cerevisiae (two other enzymes in the pathway: 3-hydroxy-3-methylglutaryl-CoA reductase and lanosterol synthase were also manipulated in these experiments) [269].

Table 43. Triterpenoids and Sterols.

\begin{tabular}{|c|c|c|c|}
\hline Name & Alternative Name(s) & CAS Number & References \\
\hline \multicolumn{4}{|l|}{ Oleananes } \\
\hline$\beta$-Amyrin (559) & 12-Oleanen-3-ol & {$[559-70-6]$} & {$[58,63,66]$} \\
\hline$\beta$-Amyrin 3-acetate (560) & 12-Oleanen-3-ol acetate & [1616-93-9] & {$[58,66,198]$} \\
\hline Oleanolic acid (561) & $3 \beta$-Hydroxy-12-oleanen-28-oic acid & [508-02-1] & {$[58,66,96]$} \\
\hline \multicolumn{4}{|l|}{ Friedalanes } \\
\hline Friedelan-3- $\beta$-ol $\quad(\mathbf{5 6 2})$ & Epifriedelanol & $\begin{array}{l}{[5085-72-3]} \\
{[16844-71-6]}\end{array}$ & {$[105]$} \\
\hline Friedelin $(\mathbf{5 6 3})$ & & {$[559-74-0]$} & [105] \\
\hline \multicolumn{4}{|l|}{ Ursanes } \\
\hline$\alpha$-Amyrin (564) & 12-Ursen-3-ol & [638-95-9] & {$[58,63,66,198]$} \\
\hline$\alpha$-Amyrenone (565) & $\begin{array}{l}\alpha \text {-Amyrone } \\
\text { 12-Urs-en-3-one }\end{array}$ & [638-96-0] & {$[58,66]$} \\
\hline \multicolumn{4}{|l|}{ Taraxastanes } \\
\hline Taraxasterone (566) & 20(30)-Taraxasten-3-one & [6786-16-9] & {$[58,66]$} \\
\hline Baurenol (567) & 7-Bauren-3-ol & [6466-49-0] & {$[58,66]$} \\
\hline \multicolumn{4}{|l|}{ Sterols } \\
\hline$\beta$-Sitosterol (568) & Stigmast-5-en-3-ol & {$[83-46-5]$} & $\begin{array}{l}{[15,59,61,63,69,75,} \\
78,96,198]\end{array}$ \\
\hline Daucosterol (569) & $\begin{array}{l}\text { Stigmast-5-en-3-ol } O \text {-beta-D- } \\
\text { glucopyranoside }\end{array}$ & {$[474-58-8]$} & {$[15]$} \\
\hline Stigmasterol (570) & Stigmast-5,22-dien-3-ol 3 $\beta(22 E, 24 S)$ & {$[83-48-7]$} & $\begin{array}{l}{[56,59,61,63,65,69,} \\
75,78,96,105,198]\end{array}$ \\
\hline
\end{tabular}

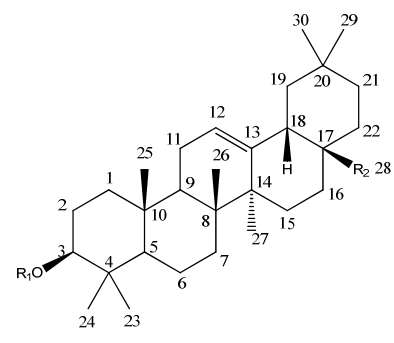

(559) $\mathrm{R}_{1}=\mathrm{H} ; \mathrm{R}_{2}=\mathrm{Me}$

(560) $\mathrm{R}_{1}=(\mathrm{C}=\mathrm{O}) \mathrm{CH}_{3} ; \mathrm{R}_{2}=\mathrm{Me}$

(561) $\mathrm{R}_{1}=\mathrm{H} ; \mathrm{R}_{2}=\mathrm{CO}_{2} \mathrm{H}$

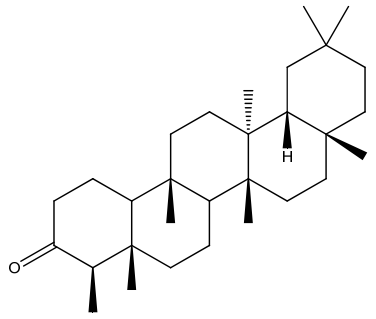

(563)

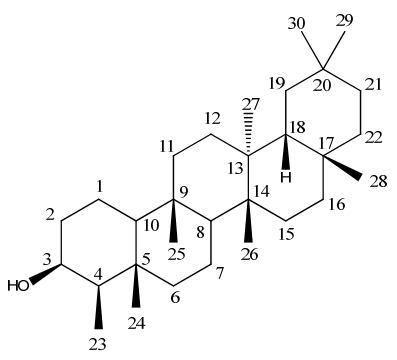

(562)

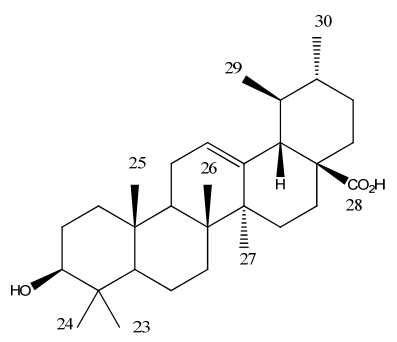

(564) 


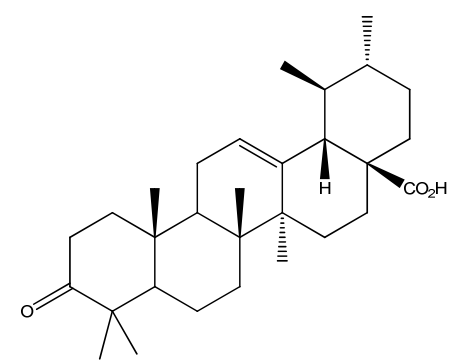

(565)

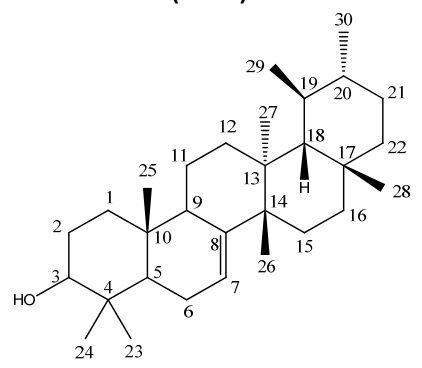

(567)

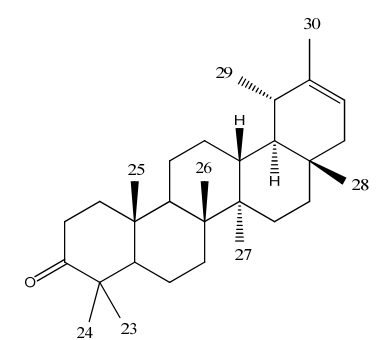

(566)

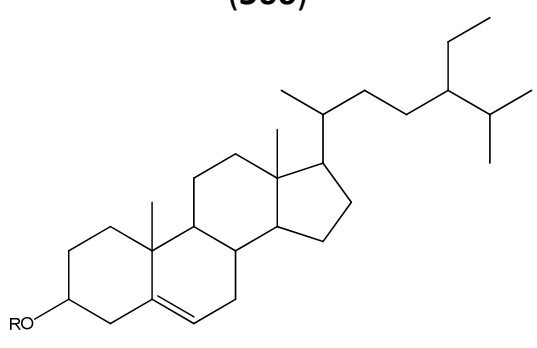

(568) $\mathrm{R}=\mathrm{H}$

(569) $\mathrm{R}=\mathrm{Glc}$<smiles>CCC(/C=C/C(C)C1CCC2C3CC=C4CC(O)CCC4(C)C3CCC12C)C(C)C</smiles>

(570)

\subsection{Nitrogen-Containing Natural Products}

Only a small number of peptides and other nitrogen-containing natural products are reported from A. апnua. These include: aurantinamide acetate ([97558-66-2]) (571)] [75], 6-amino-7,8-dihydro-2hydroxypurine (7,8-dihydro-2-hydroxyadenine) (572) [270] and benzothiazole ([95-16-9]) (573) [24].<smiles>CC(=O)O[C@H](Cc1ccccc1)NC(=O)[C@H](Cc1ccccc1)NC(=O)c1ccccc1</smiles>

(571)<smiles>Nc1nc(O)nc2c1NCN2</smiles>

(572)<smiles>c1ccc2scnc2c1</smiles>

(573)

\section{The Biosynthesis of Artemisinin (Qinghaosu)}

Terpene biosynthesis [271-276] and its regulation [277,278] in A. annua have been well reviewed, including the central role of amorpha-4,11-diene (451) in the biosynthesis of artemisinin (495) [279] 
and the likelihood that glandular trichomes are the location wherein artemisinin biosynthesis actually occurs [244,280] (indeed, it has recently been concluded that artemisinin biosynthesis occurs in the two outer apical cells of the glandular secretory trichomes [104] - the glandular trichomes of A. annua are comprised of 10 cells in total). The biosynthesis of artemisinin will be considered in three phases, as depicted in Scheme 9.

It should be emphasised that this view of the biosynthetic route to artemisinin is still not universally accepted. Although there is increasing experimental evidence in support of its general correctness, there are a significant number of experimental results (particularly in the "older" literature) which might appear to contradict Scheme 9. Thus, for many years, it was assumed that artemisinic acid ( $\mathrm{R}=\mathrm{CH}_{2}$ for $\mathbf{4 7 3}$ in place of $\mathrm{R}=\mathrm{CH}_{3}$ for $\mathbf{4 8 0}$ in Scheme 9) $[148,215,251,281-284]$, rather than dihydroartemisinic acid $\left(\mathbf{4 8 0} ; \mathrm{R}=\mathrm{CH}_{3}\right)$, was the late-stage precursor to artemisinin at the juncture between phases 2 and 3 .

Scheme 9. Three phases in the biosynthesis of artemisinin (495).

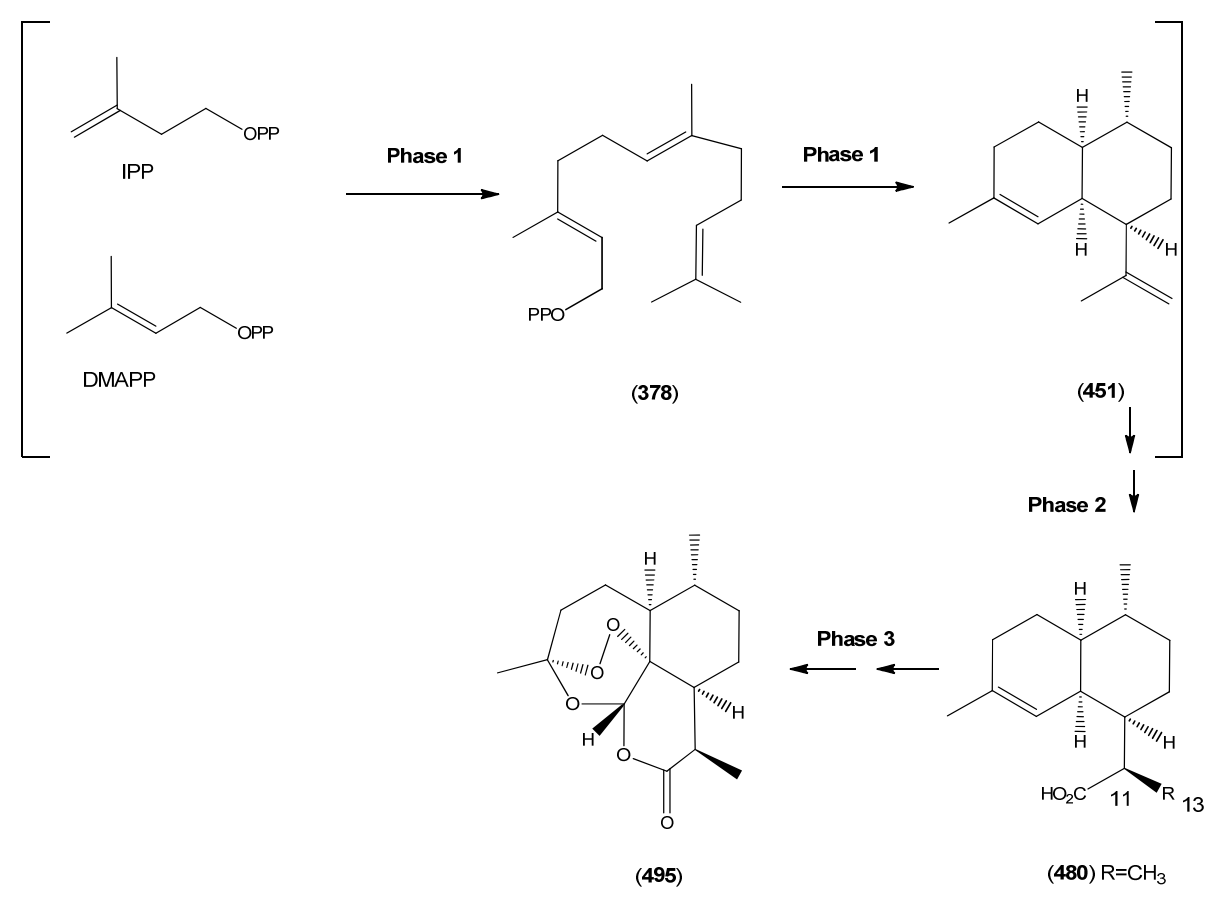

A large number of other cadinane and amorphane sesquiterpenes, including: arteannuin B (462) [248,285]; epi-deoxyarteannuin B (478) [286]; dihydroarteannuin B (479) [249]; dihydro-epideoxyarteannuin B (485) [286]; the seco-cadinane (494) [217]; and artemisitene (497) [211,248,284] have also been suggested as late-stage intermediates at or around this point in the biosynthesis (in addition, $\alpha$-epoxyartemisinic acid (487) has been stated not to be a biosynthetic intermediate to artemisinin [194]). The experimental evidence for each of these precursors is discussed individually in some detail in Section 3.3 (phase 3 of the biosynthesis of artemisinin). However, as the length of the foregoing list shows, there have been so many different proposals for phase 3 of the biosynthesis, that not all of them can be correct. In fact, none of 462, 478, 479, 485, 494 or 497 feature in the most likely biogenetic route to artemisinin (495) which is discussed first in Section 3.3, although many of these 
compounds have been implicated as side-products, in reactions which diverge away from this main biosynthetic route to (495) (see Schemes 5, 6 and 7 in Section 2.6.3 for example).

\subsection{Phase 1 (Isopentenyl Pyrophosphte to Amorpha-4,11-diene)}

This first phase in the biosynthesis of artemisinin is the least controversial, and most of the enzymes involved in the conversion of isopentenyl pyrophosphate (IPP) and its isomer dimethylallyl pyrophosphate (DMAPP) to amorpha-4,11-diene (451) have now been isolated and characterized from A. аnnua. It has been proposed that the IPP used in the biosynthesis of artemisinin comes from both the mevalonate and the mevalonate-independent pathways [287], and it has recently been demonstrated that the cental isoprenoid unit in the FPP (378) precursor to artemisinin is predominantly biosynthesized from the non-mevalonate pathway [102]. ${ }^{14} \mathrm{C}$-Labelling studies have confirmed the $\mathrm{C}_{5}$ terpenoid precursor IPP as a starting point for the biosynthetic pathway to artemisinin [288] and ${ }^{13} \mathrm{C}$ labeling studies have also been used to characterize the photosynthetic mechanism of $A$. annua as C3 [289].

The first step in phase 1 involves the conversion of IPP and DMAPP (both $\mathrm{C}_{5}$ ) to the $\mathrm{C}_{15}$ intermediate, farnesyl pyrophosphate (FPP; 378) by the enzyme farnesyl diphosphate synthase (FPPS). A cDNA encoding this enzyme, which catalyses the "head-to-tail" chain extension of a DMAPP starter by two molecules of IPP, has now been cloned from A. annua [290]. FPP sits at a branch point in terpenoid metabolism. Further elaboration to triterpenes and plant sterols (Table 43) requires the "head-to-head" coupling of two molecules of FPP, which is catalysed by the enzyme squalene synthase (SQS), as discussed in Section 2.7.2. Conversion of FPP (378) to sesquiterpenes, on the other hand, requires the operation of ionase and cyclase enzymes, such as: $(E)-\beta$-farnesene synthase (Section 2.6.1); germacrene A synthase (Section 2.6.2); $\beta$-caryophyllene synthase (Secton 2.6.2); and epi-cedrol synthase (Section 2.6.4). The comitted intermediate in the biosynthesis of artemisinin (495) is the bicyclic sesquiterpene-amorpha-4,11-diene (451) [291], which is formed from FPP (378) by the action of the sesquiterpene cyclase, amorpha-4,11-diene synthase (ADS) [138,292].

Scheme 10. Cyclization of FPP (378) to amorpha-4,11-diene (451), catalysed by the enzyme ADS.

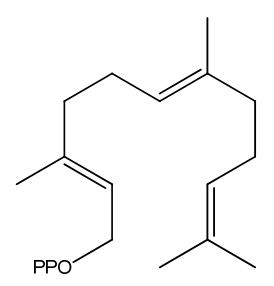

(378)

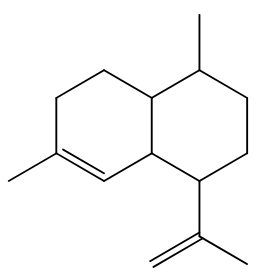

(451)
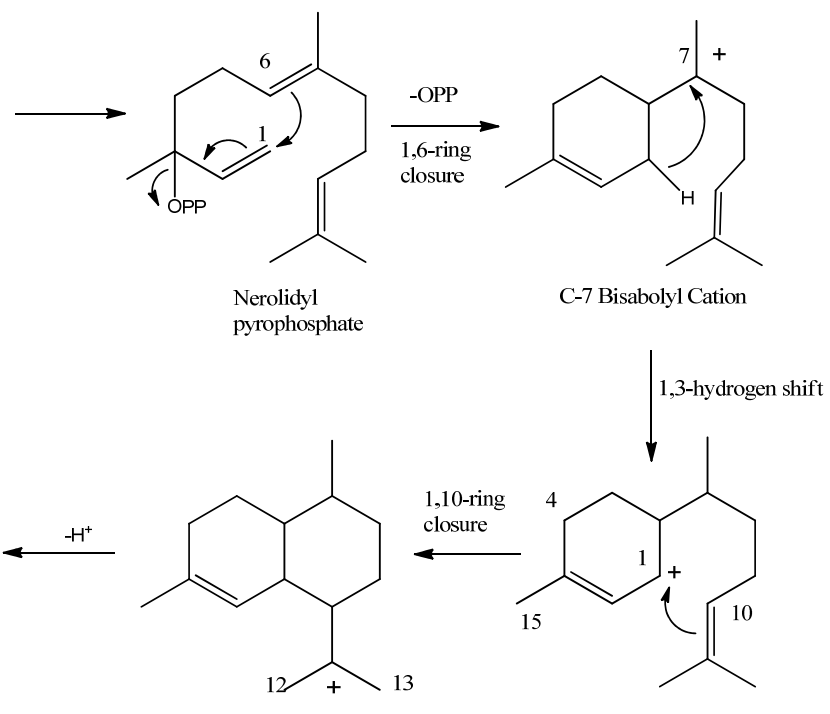

C-11 Amorphane Cation

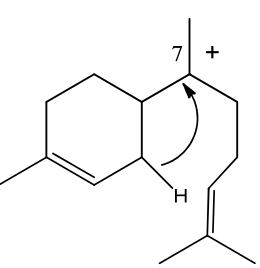

C-7 Bisabolyl Cation

C-1 Bisabolyl Cation 
cDNAs encoding ADS from A. annua have been isolated, sequenced, and expressed [293,294]. The mechanism of this particular enzymatic cyclization of FPP has now been studied in detail using a recombinant amorpha-4,11-diene synthase from A. annua. It is proposed that FPP is first isomerized to nerolidyl diphosphate; ionization of nerolidyl pyrophosphate is followed by C-1,C-6-ring closure to generate a bisabolyl cation; next, this cation undergoes a 1,3-hydride shift [295] permitting a second ring closure between the 1- and 10-positions to generate the amorphane skeleton; and, finally, deprotonation at either C-12 or C-13 affords amorpha-4,11-diene (451) [136], as is shown in Scheme 10. This mechanism is supported by GC-MS analysis of several minor sesquiterpene products which are also produced by ADS. These include the known metabolites $(E)$ - $\beta$-farnesene (382), $\alpha$-bisabolol (385), amorph-4-en-7-ol (456) and amorpha-4-7,(11)-diene (492). Other minor products from ADS have not yet been reported as natural products from $A$. annua, including the amorphane, amorph-4-en11-ol (574); the bisabolanes: $\beta$-sesquiphellandrene (1,3(15),10-bisabolatriene [20307-83-9]) (575) [134], zingiberene (1,3,10-bisabolatriene[495-60-3]) (576) and zingiberenol (1,10-bisaboladien3-ol [58334-55-7] [495-60-3]) (577); and the humulane: $\gamma$-humulene (1,3(15),6-humulatriene [2625979-0]) (578) (Figure 3) [296].

Figure 3. Minor products from the cyclization of FPP (378) by ADS, which have not yet been reported as natural products from A. annua. Amorph-4-en-11-ol (574) is probably formed by quenching of the $\mathrm{C}$-11 amorphane cation by water; $\beta$-sesquiphellandrene (575) by elimination of $\mathrm{H}-15$ from the $\mathrm{C}-1$ bisabolyl cation; zingiberene (576) from elimination of $\mathrm{H}-4$ from the $\mathrm{C}-1$ biasabolyl cation; zingiberenol (577) by quenching of the allylic $\mathrm{C}-1$ bisabolyl cation by water; and $\gamma$-humulene (578) by an alternative cyclization of nerolidyl pyrophosphate.

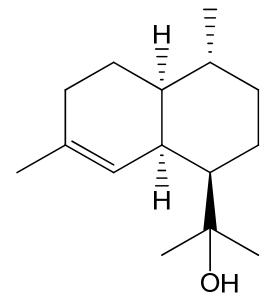

(574)

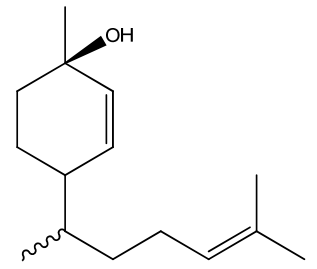

(577)

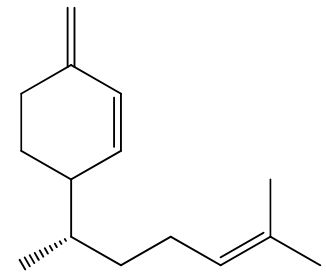

(575)

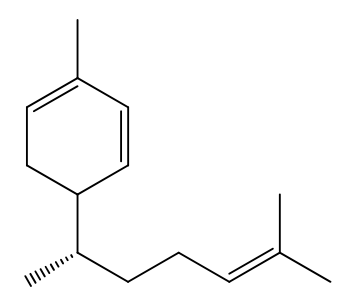

(576)

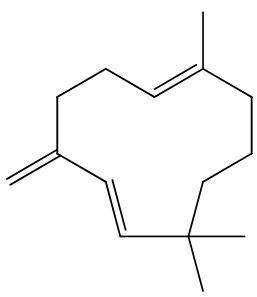

(578) 


\subsection{Phase 2 (Amorpha-4,11-diene to Dihydroartemisinic Acid)}

The second phase in the biosynthesis of artemisinin (495) involves modification to the isopropylidene group (C-11, C-12 and C-13) in amorpha-4,11-diene (451), yielding putative biosynthetic intermediates such as dihydroartemisinic acid (480) and artemisinic acid (473). Phase 2 of the biosynthesis has only recently been the subject of experimental investigation and is therefore less well understood than phase 1. In 2005, artemisinic alcohol (458), artemisinic aldehyde (460), dihydroartemisinic alcohol (482) and dihydroartemisinic aldehyde (483) were all isolated as natural products from A. annua [135]. Collectively, these metabolites suggested the presence of two interlinked pathways for the conversion of amorpha-4,11-diene (451) to either dihydroartemisinic acid (480) or artemisinic acid (473), as is shown in Scheme 11 [135].

Scheme 11. Various possible routes for the oxidation of the isopropylidene group in amorpha-4,11-diene (451), yielding artemisinic acid (473) and/or dihydroartemisinic acid (480) in phase 2 of the biosynthesis of artemisinin.

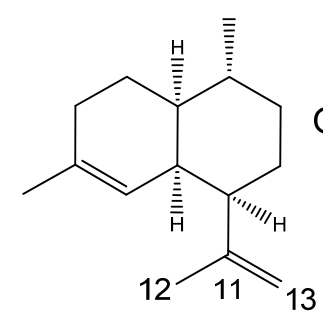

(451) (from phase 1)

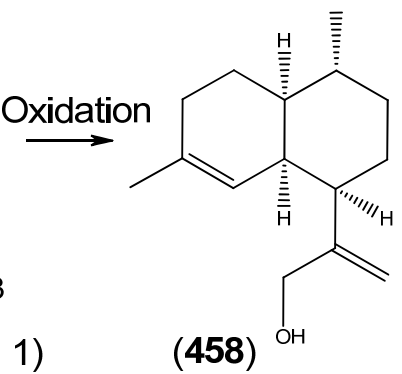

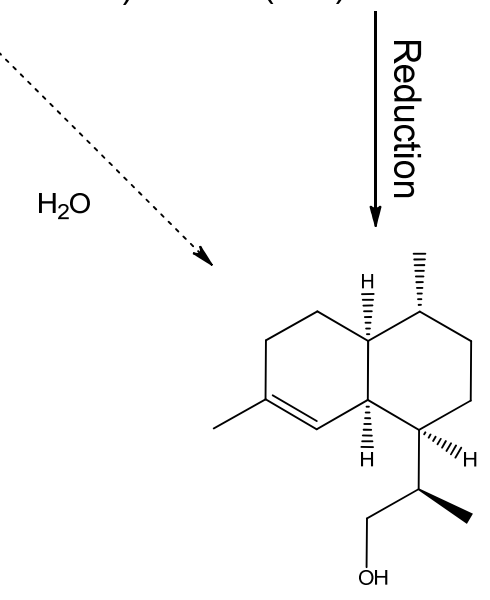

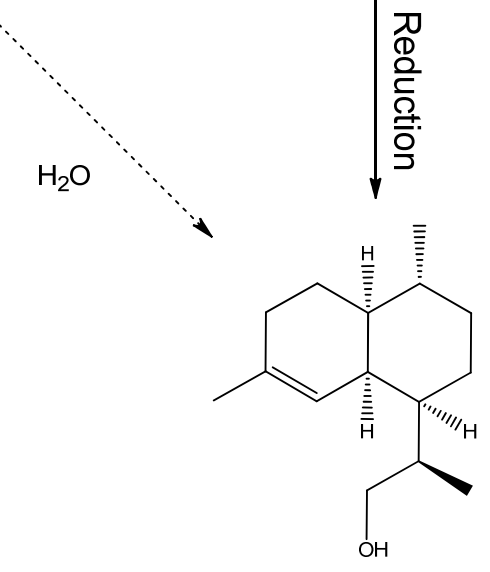

(482)

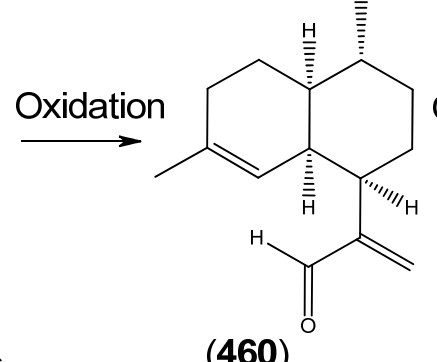

(460)

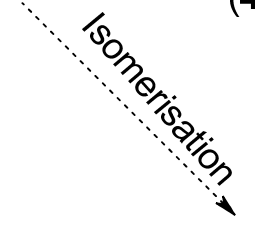

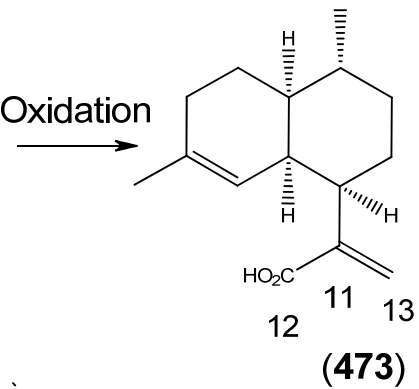

(473)

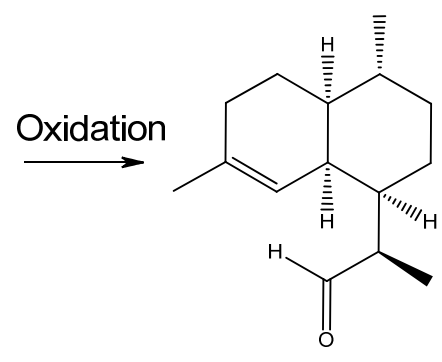

(483)
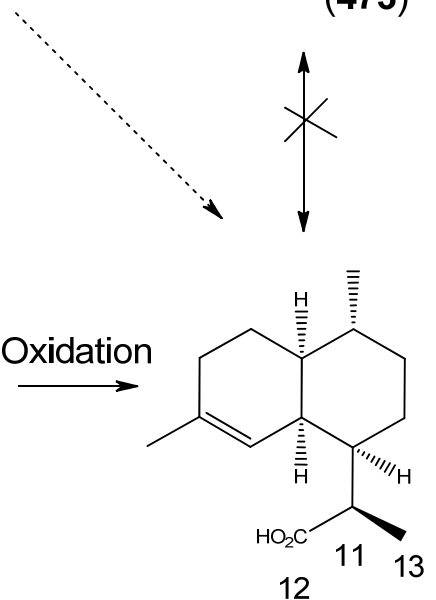

(480) (to artemisinin in phase 3)

Although it has been assumed that all transformations at the 11-, 12- and 13-positions of (451) in phase 2 would proceed either by oxidation reactions (horizontal) or by reduction reactions (vertical), it is also possible to postulate more "economical" routes, such as those involving isomerases, which the author has depicted by diagonal dashed arrows in Scheme 11. Thus, isomerization of the $\Delta^{11,13}$ bond to the $\Delta^{11,12}$ position in (458) would produce an enol, which would spontaneously tautomerize to the carbonyl group in (483), without any necessity for either reduction at C-11/13 or oxidation at C-12. A trichome-specific cDNA for the cytochrome $\mathrm{P}_{450}$ enzyme, CYP71AV1, which catalyzes three 
successive oxidations at the 12-position of amorpha-4,11-diene (451) in the "upper" oxidative pathway in Scheme 11, has now been isolated (see also Section 4.4). These three sequential oxidations of amorpha-4,11-diene (451) produce artemisinic acid (473) via artemisinic alcohol (458) and artemisinic aldehyde (460) [196] (note that the exocyclic 11,13-double bond remains intact in this route).

Historically, it has often been assumed that artemisinic acid (473) is then the starting point for the third and final phase of the biosynthesis of artemisinin. However, the most recent evidence suggests that dihydroartemisinic acid (480), produced from the saturated "lower" branch in Scheme 11, is, in fact, the true precursor to artemisinin. Kim and Kim have reported that artemisinic acid is not converted to dihydroartemisinic acid in A. annua [297] and more recent biosynthetic studies, employing both labeled artemisinic acid [155] and dihydroartemisinic acid [185], have confirmed that there is no interconversion in either direction between dihydroartemisinic acid (473) and artemisinic acid (480), as is represented by the "crossed" double-headed arrow in Scheme 11.

Therefore, if dihydroartemisinic acid (480) is the true precursor to artemisinin (495) in phase 3 of the biosynthesis, then reduction of the exocyclic double bond in amorpha-4,11-diene (451) must be occurring before artemisinic acid (473) in Scheme 11. Interestingly, there is now some evidence for such a route to dihydroartemisinic acid (480), which involves two oxidations at C-12 of amorpha-4,11diene (451), producing artemisinic aldehyde (460) via artemisinic alcohol (458); followed by reduction of the $\Delta^{11,13}$ double bond in (460) to dihydroartemisinic aldehyde (483); and, finally, oxidation of (483) at $\mathrm{C}-12$ to yield dihydroartemisinic acid (480) [135]. A recombinant DBR2 enzyme has been purified to approximately $90 \%$ from $E$. coli and found to be capable of reducing the $\Delta^{11(13)}$ double bond in artemisinic aldehyde (460) [but not in artemisinic alcohol (458), artemisinic acid (473), arteannuin B (462) or artemisitene (497)] [298]. This enzyme appears to be a member of the enoate reductase family of enzymes, with similarities to 12-oxophytodienoate reductases [298], and its discovery is potentially very significant with regard to defining the biosynthetic route from (451) to (480) in Scheme 11.

\subsection{Phase 3 (Dihydroartemisinic acid to Artemisinin)}

\subsubsection{Dihydroartemisinic Acid as a Late-Stage Precursor to Artemisinin}

In this review, it is assumed that the final steps in the biosynthetic pathway to artemisinin (495) proceed from dihydroartemisinic acid (480), rather than artemisinic acid (473) (or, indeed, any of the other late stage intermediates: 462, 478, 479, 485, 494 or 497 which have been proposed in the past). Discussions of phase 3 of the biosynthesis therefore commence with dihydroartemisinic acid (480) although the other possibilities are also evaluated in some detail in parts b) - e) of this section. Artemisinin is a seco-cadinane (Table 38), and carbon-carbon cleavage at C-4/C-5 in (495) therefore accompanies formation of the 1,2,4-trioxane ring in this final phase of the biosynthesis. No enzymes have yet been described for any of these putative reactions in phase 3. Indeed, experiments with classical plant peroxidases, a class of enzyme with the potential for involvement in these kinds of reactions, have failed to increase the yield of artemisinin [299,300].

It is also possible that the final transformations of dihydroartemisinic acid to artemisinin might proceed via non-enzymatic processes. In this regard, it is interesting to note that artemisinin biosynthesis has recently been correlated with increased levels of singlet oxygen -although this has 
been explained in terms of the upregulation of genes involved in artemisinin biosynthesis, rather than the operation of non-enzymatic processes [256]. A non-enzymatic mechanism involving molecular oxygen is particularly attractive in view of the variety of spontaneous autoxidation reactions which have already been suggested for the biogenesis of many other highly oxygenated terpenes from $A$. annua. For example, the formation of regular acyclic monoterpenes 263-265, 267, 271 and 272 in Scheme 1 (Section 2.5.1); irregular acyclic monoterpenes 279 and 280 in Scheme 3 (Section 2.5.2); eudesmane sesquiterpenes $\mathbf{4 1 3}$ and $\mathbf{4 1 4}$ in Scheme 4 (Section 2.6.3); amorphane sesquiterpenes 457, 465-467, 477, 478, 481, 484, 485 and 490 in Scheme 5; 479, 481, 485 and 493 in Scheme 6; 462, 478 and 494 in Scheme 7 (Section 2.6.3); and diterpenes 552 and 553 in Scheme 8 (Section 2.7.1) have all been proposed to proceed by spontaneous autoxidation chemistry.

The proposal that the final transformations to artemisinin (495) in phase 3 may be non-enzymatic also receives strong support both from in vivo studies [168,185] and from experiments which have been performed in vitro $[167,193,218]$, under conditions that are relevant to the living plant. Together, in vivo and in vitro experiments have suggested a mechanism for the conversion of dihydroartemisinic acid (480) to artemisinin (495) via a spontaneous autoxidation process, involving four steps, as is shown in Scheme 12.

Scheme 12. A four-step mechanism for the spontaneous autoxidation of dihydroartemisinic acid (480) to artemisinin (495) in A. annua.

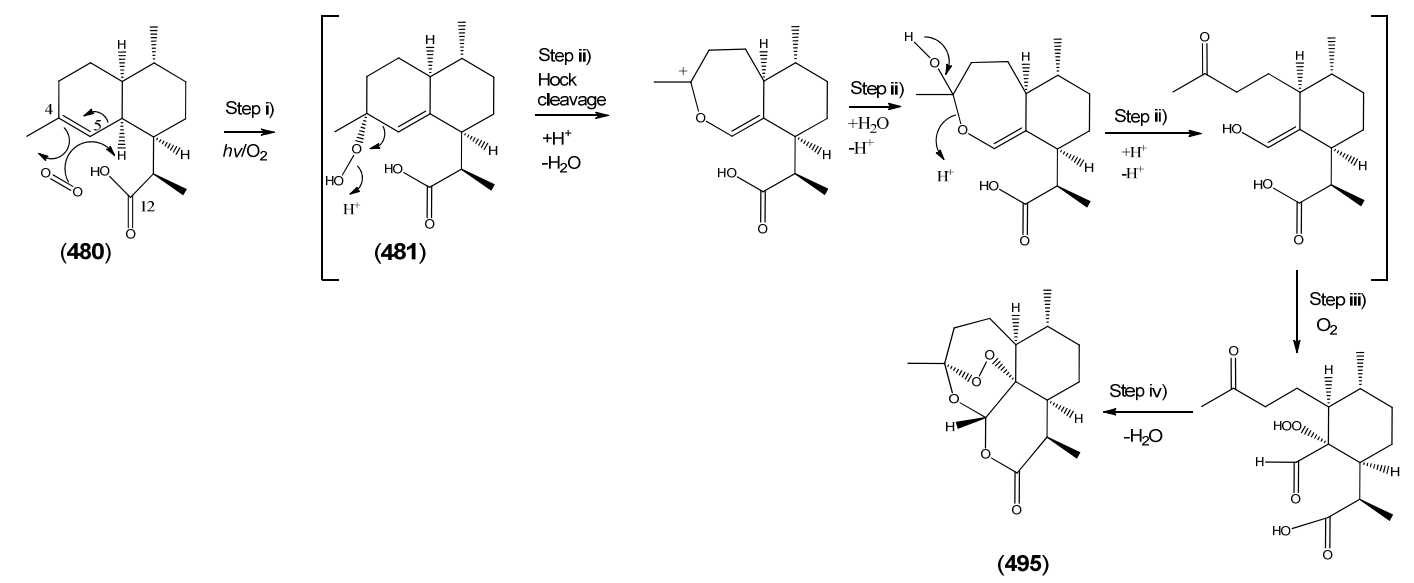

The four steps shown in Scheme 12 are: i) photo-sensitized reaction of the $\Delta^{4,5}$-double bond in dihydroartemisinic acid (480) with singlet molecular oxygen (via an "ene-type" mechanism); ii) Hock cleavage of the resulting tertiary allylic hydroperoxide 481; iii) oxygenation of the enol product from Hock cleavage; and iv) cyclization of the resulting vicinal hydroperoxyl-aldehyde to the 1,2,4-trioxane system of artemisinin (495). The tertiary allylic hydroperoxide 481, which is produced in step i), has already been shown to be a biosynthetic intermediate, linking dihydroartemisinic acid (480) and artemisinin (495), by in vivo experiments with labeled dihydroartemisinic acid (480) $[185,189]$. Compound $\mathbf{4 8 1}$ has also been described independently as a natural product from A. annua [167,170]; and quantitative studies, which monitored the decline of dihydroartemisinic acid (480) and the increase of artemisinin (495) during leaf development and senescence have confirmed that an intermediate, such as 481, is probably involved in this conversion [301] [it is interesting to note that the alternative secondary allylic hydroperoxide from the spontaneous autoxidation of dihydroartemisinic acid (480) in 
step i] has also been proposed as the precursor to another amorphane sesquiterpene endoperoxide from A. annua, arteannuin H (465) [166], as is shown in Scheme 5 in Section 2.6.3).

There is - as yet - no direct evidence from in vivo studies to suggest how further transformation of 481 to the 1,2,4-trioxane ring in artemisinin might occur in A. annua. The evidence for steps ii)-iv) which are proposed in Scheme 12 comes solely from in vitro studies, conducted with the tertiary allylic hydroperoxide 481 [171,236,237,239,254], which can be obtained in good yield from photosensitized oxygenation of $\mathbf{4 8 0}[193,218]$. These in vitro experiments have shown that $\mathbf{4 8 1}$ can indeed undergo sponataneous conversion to a transient enol as proposed in step ii) of Scheme $11[204,238,243,302,303]$, and it has even been possible to fully characterize this unstable intermediate by 2D-NMR at low temperature [193]. This known reaction of allylic hydroperoxides is referred to as a Hock cleavage (or a Criegee rearrangement) and it is in this step that carbon-carbon bond cleavage occurs between C-4 and C-5, thereby producing the seco-cadinane skeleton of artemisinin (495).

The double bond in the enol which is produced by step ii) then reacts rapidly with a second molecule of oxygen in step iii). This reaction most probably proceeds via an "ene-type" mechanism similar to that for the conversion of $\mathbf{4 8 0}$ to $\mathbf{4 8 1}$, although apparently without the requirement for light (i.e. ${ }^{3} \mathrm{O}_{2}$ rather than ${ }^{1} \mathrm{O}_{2}$ is perhaps the active species) $[193,236,304,305]$. All carbons in the resultant $\alpha$ aldehydo hydroperoxide [238] are now at the correct oxidation level and this intermediate immediately "zips up" to the 1,2,4-trioxane ring of artemisinin (495) in step iv).

It has been speculated that the proximity of the 12-carboxylic acid group to the $\Delta^{4,5}$-double bond in $\mathbf{4 8 0}$ and the hydroperoxide functionality in $\mathbf{4 8 1}$ might be the reason why both transformations i) and ii) proceed with such apparent ease in vitro [218]. Finally, it is worth reiterating that both in vivo and in vitro studies have shown that the tertiary allylic hydroperoxide 481 can be transformed into a wide variety of other compounds, in addition to artemisinin (495). Many of these compounds have been obtained previously as natural products from A. annua (see Schemes 5 and 6 in Section 2.6.3). Inspection of Scheme 12 suggests that some of these metabolites, such as dihydroarteannuin B (479) and dihydro-epi-deoxyarteannuin B (485) may be formed by alternative reactions to the Hock cleavage of $\mathbf{4 8 1}$ in step ii), while others such as the seco-cadinane $\mathbf{4 9 3}$ may arise by alternative reactions of the enol from Hock cleavage in step iii).

\subsubsection{Artemisinic Acid (473) as a Late-Stage Precursor to Artemisinin}

$\left[2-{ }^{14} \mathrm{C}\right]-$ Mevalonic acid lactone has been shown to be incorporated into artemisinic acid (473) in A. annua using plantlet hydroponic and stem tip feeding methods [306]. Several experiments in the older literature (1990's and earlier) have suggested that artemisinic acid (473) can then be converted in to both arteannuin B (462) and artemisinin (495) [215,281,285]. All these experiments employed radiolabelled forms of artemisinic acid that were presented to cell-free systems, which had been derived by extensive manipulations of $A$. annua plants. However, the most recent biosynthetic study [155], which employed stable isotope-labeled artemisinic acid [15- $\left.\left[{ }^{2} \mathrm{H}_{3}{ }^{13} \mathrm{C}\right]-(473)\right]$ administered to a whole plant system, seemed to show that artemisinic acid was not a biosynthetic precursor to artemisinin. The experimental conditions for this study were purposely chosen to allow comparison with a previous investigation, which had demonstrated that dihydroartemisinic acid $\left[15-\left[{ }^{2} \mathrm{H}_{3}{ }^{13} \mathrm{C}\right]-\right.$ (480)] was a precursor to artemisinin (495)) [185] (see discussion in a) above). In addition, it should be 
noted that a separate study with a cell-free system has also confirmed that dihydroartemisinic acid (480) is a precursor to artemisinin in A. annua, while artemisinic acid (473) is not [307].

One explanation for these apparently contradictory results with artemisinic acid (473) may lie in the differing experimental approaches which have been adopted. The threshold for detection by NMR of a metabolite which is labeled with a stable isotope is likely to be several orders of magnitude higher than the corresponding threshold for a radioisotpic label. Thus, it is possible that the "older" experiments (1990s and earlier), which detected radiolabel, might - in reality - be identifying only trace quantities of metabolites, which were not derived directly from the labeled precursor. It is possible that partial degradation of a radio-labeled precursor can lead to some radioactivity appearing in a "pool" of small molecules, such as acetyl-CoA (see Scheme 13). These small molecules would then serve as precursors for several biosynthetic pathways, including the terpenoid pathway, and could thereby be incorporated indirectly into many metabolites from such pathways. By contrast, the stable isotopelabeled metabolites which have been detected by NMR [155] represented at least 1\% (very often between $5-30 \%$ ) of the label that had been supplied and therefore provide a picture only of the most significant and direct transformations which have been undergone by the precursor. In addition, it should also be pointed out that the possibilities for introducing artifacts when performing feeding studies with whole plants, which require no external manipulation, is likely to be significantly reduced as compared to cell-free extracts, which must endure many perturbations to the biological system (homogenization, addition of buffers etc..).

Although the most recent experiments with artemisinic acid (473) failed to observe any detectable incorporation into artemisinin, a very significant conversion was observed into arteannuin B (462), as well as six other highly oxygenated sesquiterpene natural products, all of which retained the 11,13double bond, as shown in Scheme 7 in Section 2.6.3 [155] [furthermore, there was no evidence for conversion to any 11,13-dihydro metabolite, including artemisinin (495)]. Such transformations can most easily be accounted for by oxidation of the $\Delta^{4,5}$-double bond in 473 to a hydroperoxide, analogous to that postulated in Scheme 12 for dihydroartemisinic acid (481). There is indeed ample precedent for the formation of such hydroperoxides from 473 by photooxygenation reactions in vitro [243], which lead both to arteannuin B (462) [251] and 11,13-dehydro analogues of artemisinin [254,308].

In conclusion, although the absence for any detectable transformation of artemisinic acid into artemisinin in the most recent study [155] is at variance with the earlier literature (pre1990's) [281,284,286] for the biosynthesis of artemisinin, it is consistent with much of the more recent literature (post-1990's), in which there is now a gathering consensus that dihydroartemisinic acid (480), rather than artemisinic acid (473), is the true late-stage precursor to artemisinin (495).

\subsubsection{Arteannuin B (462) and Dihydroarteannuin B (479) as Late-Stage Precursors to Artemisinin}

As noted above, in the most recent study of the metabolism of artemisinic acid, arteannuin B (462) was obtained as the major metabolite of artemisinic acid (473), without any evidence for the accompanying formation of artemisinin (495) [155]. However, because both arteannuin B (462) and artemisinin (495) were often reported together from "older" biosynthetic studies with artemisinic acid (473), some authors have previously proposed that arteannuin B (462) might be an intermediate in the 
proposed conversion of artemisinic acid (473) [215,251] to artemisinin (495) [203,248,285]. It is indeed possible to convert arteannuin B into artemisinin by chemical transformations [239] and there have been various suggestions as to mechanisms by which this transformation might also occur in vivo [209,217]. A microbial system which is capable of converting arteannuin B (462) to artemisinin (495) has recently been described [309] and an enzyme with the appropriate activity has also been purified [310,311]. On the other hand, a study which found that epoxyartemisinic acid (487) could be converted to arteannuin B (462) also stated that epoxyartemisinic acid (487) could not be transformed into artemisinin (495) and therefore - by implication - arteannuin B cannot be a precursor to artemisinin [284]. It has also been claimed that the 11,13-dihydro analogue of arteannuin B (462), dihydroarteannuin B (479), can be converted into artemisinin by cell free extracts of $A$. annua $[249,312]$.

\subsection{4. epi-Deoxyarteannuin B (478) and Dihydro-epi-deoxyarteannuin B (485) as Late-Stage} Precursors to Artemisinin

epi-Deoxyarteannuin B (478) was obtained as a minor metabolite of artemisinic acid (473), without any evidence for the accompanying formation of artemisinin (495), in the most recent study of the metabolism of artemisinic acid [155]. However, experiments in the "older" literature (1990's and before), using radiolabelled forms of both epi-deoxyarteannuin B (478) and its 11,13-dihydro analogue, dihydro-epi-deoxyarteannuin B (485), have suggested that both were intermediates [286] in the respective biotransformations of artemisinic acid (473) and dihydroartemisinic acid (480) to artemisinin (495) [284]. However, once again, more recent experiments using dihydro-epideoxyarteannuin B (485) which had been labelled with a stable isotope [169] and fed to an intact plant system have shown no detectable incorporation into artemisinin (495); although three novel hydroxylated metabolites were obtained in significant quantities from this feeding experiment [190].

\subsubsection{The seco-Cadinane (494) and Artemisitene (497) as Late-Stage Precursosr to Artemisinin}

The seco-cadinane aldehyde (494) has been hypothesized to be a precursor to artemisinin (495) via its enol tautomer, which undergoes reaction with molecular oxygen * to produce artemisitene (497), the 11,13-dehydro analogue of artemisinin (this reaction was proposed to occur in a similar manner to the transformations which have now been established experimentally for the enol in steps iii) and iv) in Scheme 12 [217,313]). Artemisitiene (497) can then reportedly be converted into artemisinin (495) in vivo [240] [the enol of $\mathbf{4 9 4}$ was proposed to be derived from Grob fragmentation of the vicinal diol 486, which is in turn derived from arteannuin B (462)].

\section{Strategies for the Production of Artemisinin from A. annua and Derived Systems}

Although artemisinin can be produced by chemical synthesis [171,228-239], the structural complexity of this target and the large number of steps involved in all published synthetic routes render this approach far too expensive for many in the Third World who are most affected by malaria. Various alternative possibilities for the production of artemisinin from A. annua and derived systems have therefore been extensively investigated, and this topic has been amply reviewed [313-320]. Four 
strategies are considered in this review, all of which might benefit from a knowledge of the full biosynthetic pathway to artemisinin. These are: 1 . Plant breeding programmes; 2 . Plant tissue culture; 3. Endophytic fungi; and 4. Genetic engineering. The most successful strategy to date has been plant breeding, resulting in the cultivar "Artemis", which was registered in Switzerland in 1999, and contains up to $1.4 \%$ artemisinin (by comparison, the extremely variable yields obtained from wild varieties of A. annua typically range between $0.01-0.5 \%$ artemisinin [321]). There is a potential for even higher yields in the future from on-going plant breeding programmes, such as that of the CNAP Artemisia project at the University of York (UK) [195].

Recent attempts to produce artemisinin through fermentation, by genetically engineering several enzymes from $A$. annua in to a microbial host, would seem to have the greatest promise for the cheap and reliable production of artemisinin. This approach, pioneered by the synthetic biologist Jay Keasling at UC Berkeley (USA), has so far yielded microbially-produced artemisinic acid (473), which is then transformed to artemisinin (495) in a separate chemical process [see Section 3.3b for a discussion of the confusion surrounding the true biosynthetic status of artemisinic acid (473)]. Amyris Biotechnologies and Sanofi-aventis are currently developing a commercial-scale manufacturing process, which is based on this semi-synthetic approach to artemisinin.

The discussions in Sections 4.1-4.4 emphasize how a full understanding of both the phytochemistry of A. annua and the biosynthesis of artemisinin can be helpful for improving the production of this important antimalarial drug by each of these four strategies.

\subsection{Plant Breeding Programmes}

Plant selection and breeding programmes have often sought to combine the properties of artemisinin-rich clones of $A$. annua (such as the Chinese and Vietnamese varieties), with more vigorous but lower-yielding clones (such as some of the European varieties) in order to achieve a robust hybrid with a high yield of artemisinin (typically $1 \%$ or more - corresponding to an agricultural yield of approximately $200 \mathrm{Kg} /$ ha for dry leaves) [322-324]. There is increasing evidence that artemisinin production in $A$. аnnua is localized in the biseriate glandular trichomes: specialized structures, found predominantly on the surface of leaves and flowers [244,325]. Several authors have reported that the artemisinin content is highest just before flowering [326-328] (interestingly, this trend is apparently not followed by other metabolites: the content of artemisia ketone (276) decreases before flowering and then increases afterwards; caryophyllene (405) shows the opposite trend; while levels of monoterpenes, such as cineole (326), bornyl acetate (335) and camphor (341) all remain relatively constant throughout growth [112]) and it has also been noted that the content of artemisinin can be up to ten-fold higher in flowers, as compared with leaves [19,329,330]. These observations may simply reflect an increased density of glandular trichomes in the flowers [301], and hence a correspondingly higher yield of artemisinin. By contrast, artemisinic acid (473) seems to be obtained in maximum yield at the late vegetative stage (however, the concentration of artemisinic acid in A. annua (473) is strongly dependant on chemotype - it can be up to ten-fold higher than that of artemisinin in European and Chinese varieties, although this is reversed in Vietnamese strains).

It has also been observed that increased illumination or sunlight results in a higher yield of artemisinin [331-333]. This would be consistent with the hypothesis that the final steps in the 
biosynthesis of artemisinin proceed in the trichomes by spontaneous autoxidation reactions of dihydroartemisinic acid (480), requiring ${ }^{1} \mathrm{O}_{2}$, which is produced in the presence of light and a photosensitizer (e.g., chlorophyll - see step i) in Scheme 12). Several researchers have endeavoured to quantify not just the amount of artemisinin (495) [334], but also its presumed biosynthetic precursors, dihydroartemisinic acid (480) [335] and artemisinic acid (473) [335-337], when studying the developmental biology of $A$. annua. One particularly interesting study has concluded that correlated variations in all three natural products prove the existence of chemotypes of $A$. annua. Thus, plants with a high artemisinin (495) level were found also to have a high dihydroartemisinic acid (480) level, but a relatively low concentration of artemisinic acid (473); while chemotypes with low levels of artemisinin (495) and dihydroartemisinic acid (480) contained a correspondingly high concentration of artemisinic acid (473) [338]. These findings were explained [20] on the assumption that the enzymatic reduction of artemisinic acid (473) to dihydroartemisinic acid (480) might represent a "bottle neck" in the biosynthetic pathway to artemisinin (495). However, given that it seems now to be proven that artemisinic acid (473) is not a precursor to dihydroartemisinic acid (480) (see crossed arrow in Scheme 11) $[155,185]$, the existence of these two chemotypes might instead be explained on the assumption that artemisinic acid (473) is a "dead end" metabolite, leading "away" from artemisinin (495) in phase 2 of the biosynthetic route, as is implied in Scheme 11.

Finally, there have been several recent attempts to create transgenic A. annua plants with elevated levels of artemisinin [339-341] by transferring genes for various enzymes in the biosynthetic pathway to artemisinin (e.g. HMGR, FPPS, ADS and CYP71AV1 - see Scheme 13).

\subsection{Plant Tissue Culture}

The production of artemisinin from plant tissue cultures of A. annua has been reviewed [342]. Although artemisinin can be obtained in reasonable quantities from differentiated shoot cultures [343-345], it is produced in only small or undetectable amounts [346-348] by callus or suspension cell cultures of $A$. annua. Instead, the chemistry of undifferentiated callus and suspension cultures of $A$. annua seems to be dominated by sterols, such as stigmasterol (570) and sitosterol (568) (Section 2.7.2) [86,313]; as well as phenylpropanoids, such as scopoletin (184) (Section 2.3; Table 17), all of which are also found in significant quantities in the parent plants [86,313]. Other phenylpropanoids, such as 4-methoxycinnamaldehyde (579), coniferaldehyde (580), (2-glyceryl)-O-coniferaldehyde (581) [87], (2-propenal)-O-coniferaldehyde (582) [87] and balanophonin (583) [87] are not yet known from $A$. annua plants themselves (Figure 4). The triglyceride, glycerol 1,2-di-9-octadecenoate 3-octadecanoate (584), with some structural similarities to 9-octadecenoic acid, 2,3-dihydroxypropyl ester (82) (Table 5), has also been obtained from plant tissue culture [86]. These major alterations observed in the metabolism of undifferentiated callus and suspension cultures may reflect the absence of glandular trichomes, in which much of the biosynthesis of the mono- and sesquiterpenoids which are described in Sections 2.5 and 2.6 is thought to occur.

Much of the current research activity into the production of artemisinin by plant tissue culture revolves around hairy root cultures of $A$. annua [349] which have been transformed by Agrobacterium tumefaciens [350,351] (elicitors from endophytic fungi - see the next section - have also been employed in $A$. annua plant tissue cultures [202,352,353]). Correlations have been observed between peroxidase activity and 
artemisinin levels in hairy roots [354], although it has also been suggested that a high peroxidase activity in cell cultures may be partly responsible for their very low artemisinin contents observed [355].

Figure 4. Metabolites which have been isolated from tissue culture of A.annua, but which have not yet been reported from A. annua plants.
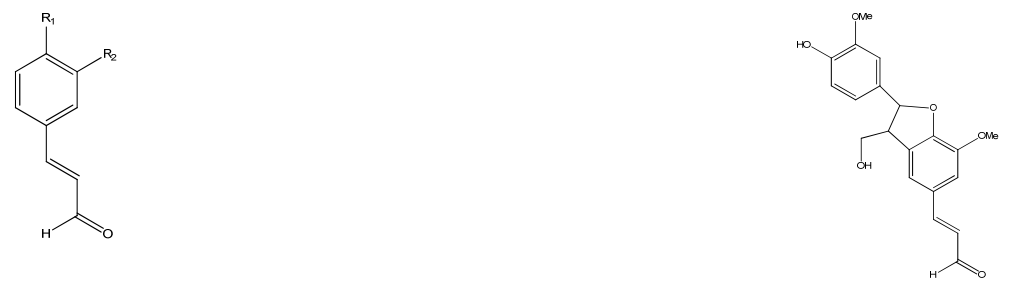

(579) $\mathrm{R}_{1}=\mathrm{OMe} ; \mathrm{R}_{2}=\mathrm{H}$

(580) $\mathrm{R}_{1}=\mathrm{OH} ; \mathrm{R}_{2}=\mathrm{OMe}$

(581) $\mathrm{R}_{1}=\left(\mathrm{HOCH}_{2}\right) \mathrm{CH}\left(\mathrm{CH}_{2} \mathrm{OH}\right) ; \mathrm{R}_{2}=\mathrm{OMe}$

(582) $\mathrm{R}_{1}=\mathrm{H}_{2} \mathrm{C}=\mathrm{C}(\mathrm{CHO}) ; \mathrm{R}_{2}=\mathrm{OMe}$

(583)

\subsection{Endophytic fungi}

Endophytic fungi live symbiotically within the tissues of many plants. Interest in endophytic fungi as a novel source of plant-derived drugs was first sparked by the observation of the lateral transfer of genes which are involved in the biosynthesis of taxol (paclitaxel) from Taxus brevifolium L. [356] - the plant which produces this important anti-cancer compound - to an endophytic symbiont. Thus, if it were found that some of the genes for the biosynthetic pathway to artemisinin in A. annua had been "naturally" transferred to an endophyte which inhabited this species, then it might be possible to utilize that endophyte for the production of artemisnin in a fermentation process. Several endophytes have now been described from A. апnua [357]. While chemical studies of such endophytic fungi have demonstrated a fascinating variety of natural product chemistry (see Table 44), only one strain is so far reported as a potential source of artemisinin [358].

Table 44. Natural Products from Endophytic Fungi Found in A. annua.

\begin{tabular}{|c|c|c|}
\hline Endophyte & Compound & Reference \\
\hline \multirow[t]{3}{*}{ Myrothecium roridum (IFB-E009; IFB-E012) } & Myrothecine A (585) & [359] \\
\hline & Myrothecine B (586) & [359] \\
\hline & Myrothecine C (587) & [359] \\
\hline \multirow[t]{4}{*}{ Hypoxylon truncatum (IFB-18) } & Daldinone C (588) & [360] \\
\hline & Daldinone D (589) & [360] \\
\hline & Altechromone A (590) & {$[360]$} \\
\hline & (4S)-5,8-Dihydroxy-4-methoxy- $\alpha$-tetralone (591) & [360] \\
\hline \multirow[t]{2}{*}{ Leptosphaeria sp. (strain number IV403) } & Leptosphaeric acid (592) & {$[361]$} \\
\hline & Leptosphaerone (593) & [362] \\
\hline \multirow[t]{11}{*}{ Colletotrichum sp. } & $3 \beta$-Hydroxy-ergosta-5-ene (594) & [363] \\
\hline & Ergosterol (595) & [363] \\
\hline & $3 \beta, 5 \alpha, 6 \beta$-Trihydroxyergosta-7,22-diene (596) & {$[363]$} \\
\hline & $3 \beta, 5 \alpha$-Dihydroxy- $6 \beta$-acetoxy-ergosta-7,22-diene (597) & [363] \\
\hline & $3 \beta, 5 \alpha$-Dihydroxy- $6 \beta$-phenylacetyloxy-ergosta-7,22-diene (598) & [363] \\
\hline & $3 \beta$-Hydroxy- $5 \alpha, 8 \alpha$-epidioxy-ergosta-6,22-diene (599) & [363] \\
\hline & $3 \beta$-Hydroxy- $5 \alpha, 8 \alpha$-epidioxy-ergosta-6,9(11),22-triene (600) & [363] \\
\hline & 3-Oxo-ergosta-4-ene (601) & [363] \\
\hline & 3-Oxo-ergosta-4,6,8(14),22-tetraene (602) & [363] \\
\hline & Indole-3-acetic acid (603) & [363] \\
\hline & 6-Isoprenylindole-3-carboxylic acid (604) & {$[363]$} \\
\hline
\end{tabular}


Table 44. Cont.

(5)<smiles>[R]c1ccc2c(C(=O)O)c[nH]c2c1</smiles>

(603) $\mathrm{R}=\mathrm{H}$

(604) $\mathrm{R}=\mathrm{CH}_{2} \mathrm{CH}=\mathrm{C}\left(\mathrm{CH}_{3}\right)_{2}$

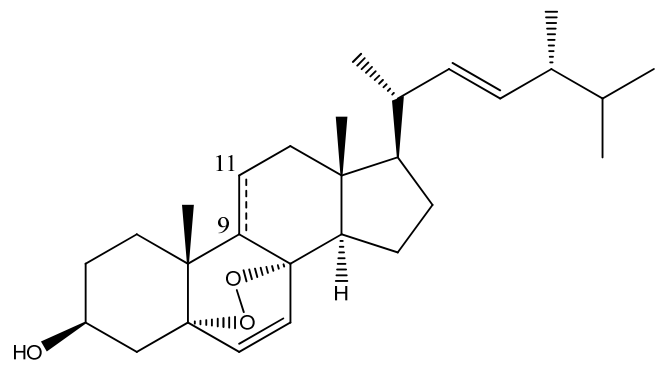

(599) 9,11-saturated (600) $\Delta^{9,11}$ (595) $\Delta^{7,8} ; \Delta^{22,23}$

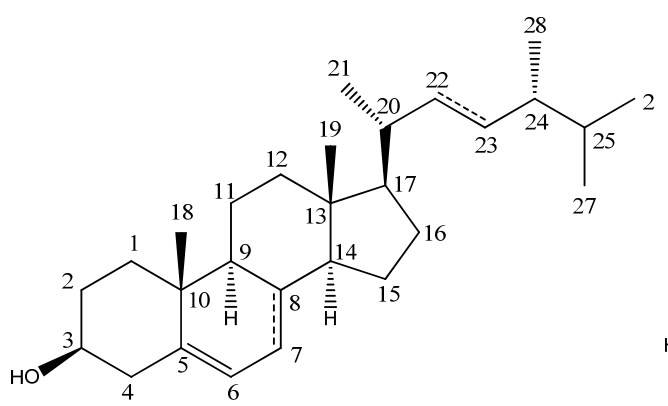

(594) 7,8-saturated; 22,23-saturated

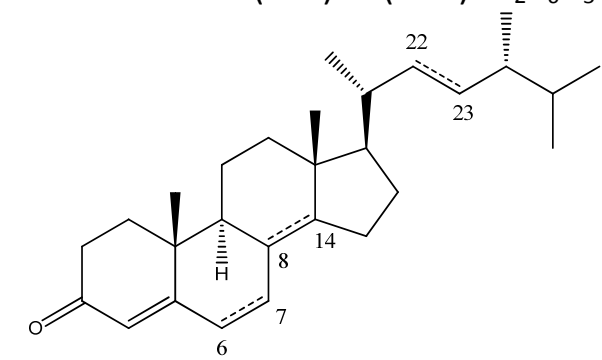

(601) 6,7-saturated; 8,14-saturated; 22,23-saturated (602) $\Delta^{6,7} ; \Delta^{8,14} ; \Delta^{22,23}$ 


\subsection{Genetic Engineering}

Metabolic engineering has attracted increasing attention over recent years as an alternative means for the production of plant-derived drugs. Both artemisnin from A. annua and taxol from Taxus brevifolium are attractive targets for this emerging science of synthetic biology since both drugs are available in only limited quantities from the natural source and are also difficult to synthesize chemically [364]. Research into the production of artemisinin from such genetically modified microorganisms has been well reviewed [365-369].

The goal of synthetic biology is to reprogram a microorganism for the efficient production of a natural product by establishing new metabolic pathways, which lead to the formation of the desired metabolite, whilst simultaneously removing existing metabolic pathways which detract from the formation of such a product. To date, investigators have concentrated on expressing the enzymes from phases 1 and 2 of the biosynthetic route to artemisinin in transgenic organisms (see Scheme 9 in Section 3). These have included: HMG-CoA reductase (HMGR) [370]; farnesyl diphosphate synthase (FPPS) [371-374]; amorpha-4,11-diene synthase (ADS) [375-377]; and the $\mathrm{P}_{450}$ enzyme which oxidises amorpha-4,11-diene to artemisinic acid (CYP71AV1) [378] (Scheme 13). Both Saccharomyces cerevisiae [379,380] and Escherichia coli [381-383] have been used as hosts when attempting to establish a viable recombinant microbial pathway for the biosynthesis of artemisinin.

The approach outlined in Scheme 13 has succeded in producing high levels of amorpha-4,11-diene (451) from E. coli [384] and artemisinic acid (473) from S. cerevisiae in quantities which exceed those from A. annua itself $\left(100 \mathrm{mg}^{-1} \cdot \mathrm{g} \cdot \mathrm{L}^{-1}\right)[385,386]$. The semi-synthesis of artemisinin (495) from microbially-produced artemisinic acid (473) then requires two further chemical steps: reduction of the exocyclic double bond; and photo-sensitized oxidation of the endocyclic double bond to produce the 1,2,4-trioxane ring in (495) [156,237]. Fortunately, the genetically-engineered yeast transports artemisinic acid (473) outside of the cell, where it is retained on the cell wall, and can easily be released simply by altering the $\mathrm{pH}$. It is then necessary to purify microbially-produced artemisinic acid (473) prior to these chemical transformations.

Scheme 13. Genetic engineering of enzymes for the production of artemisinic acid (473) from A. annua in to a microbial host.

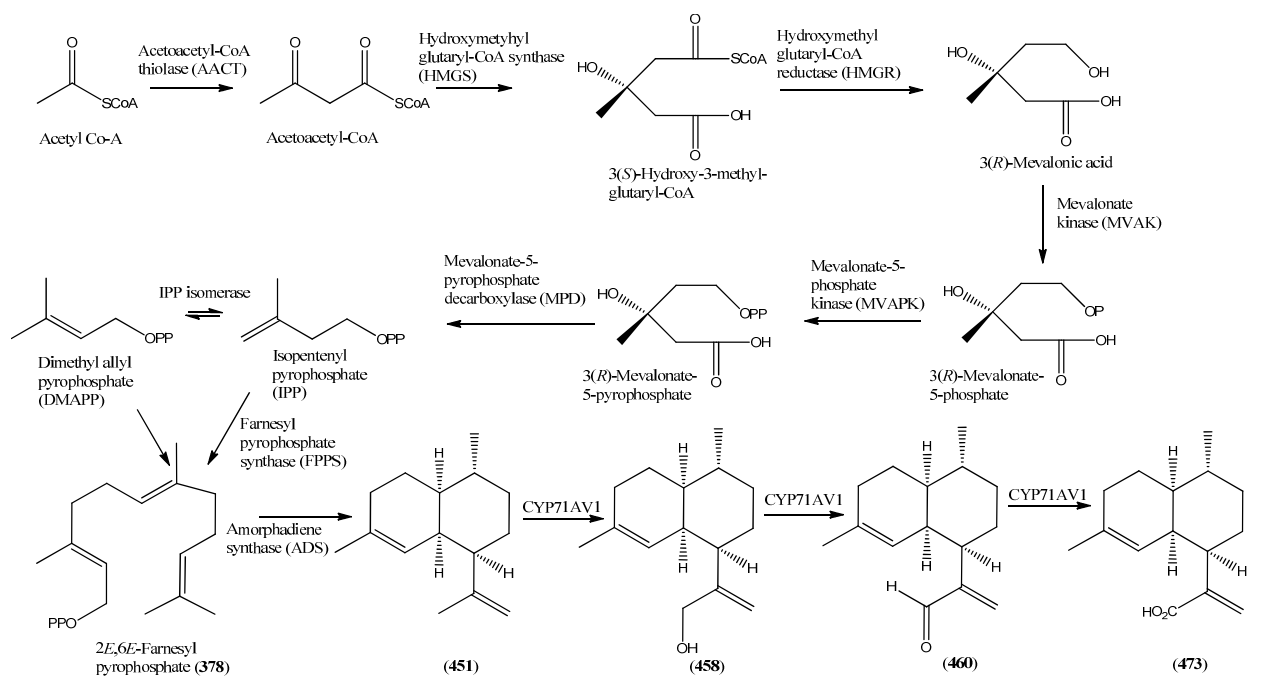


In order to achieve the heterologous production of artemisinin (495) by a large-scale fermentation process, it will be necessary to express every step in the biosynthetic pathway to artemisinin in a microbe. Keasling has observed that "the production of drugs via heterologous pathways in microbial hosts is frequently hindered by insufficient knowledge of the native metabolic pathway and its cognate enzymes; often the pathway is unresolved, and the enzymes lack detailed characterization" [387]. These comments are certainly pertinent to the biosynthesis of artemisinin in A. annua, as is evident from the foregoing discussions in Sections 3.2 and 3.3. The author would argue that the prerequisite for the reconstruction of the complete biosynthetic pathway to artemisinin (495) in a transgenic yeast or bacterium is the elucidation of the full details of phase 2 of the biosynthesis in A. annua, in which amorpha-4,11-diene (451) is converted to dihydroartemisinic acid (480); as well as a better understanding of phase 3, in which 480 is then converted to 495 (see Scheme 9). If this can be achieved, then it should - at the very least - be possible to produce dihydroartemisinic acid (480), rather than artemisinic acid (473), by the fermentation of simple sugars (in fact, the production of dihydroartemisinic acid (480) in yeast using the Dbr2 gene has now been described [298] - see also discussion at the end of Section 3.2 - and the use of substrate-promiscuous enzymes as an alternative means for the microbial production of (480) is also under investigation [387]).

If the final stages in the conversion of dihydroartemisinic acid (480) to the 1,2,4-trioxane ring in artemisinin (495) (phase 3 in Section 3.3) do turn out to be enzymatically catalysed, then it may indeed be possible to genetically engineer all the enzymes for the complete biosynthetic pathway to artemisinin (495) into a microbial system. The current evidence, however, points to the final steps in the biosynthesis of artemisinin (495) being non-enzymatic - most probably proceeding by spontaneous autoxidation reactions, which occur in the hydrophobic environment of a glandular trichome. If this is the case, then the simplest approach might be to engineer a microorganism to produce dihydroartemisinic acid (480) which is exported out of the cell, where it can more easily be isolated and purified [in much the same way that genetically-engineered yeast accumulates artemisinic acid (473) on the cell surface]. Inevitably, a chemical oxidation step would still then be required in order to convert microbially-produced dihydroartemisinic acid (480) to artemisinin (495), but this would certainly represent a saving in time and cost by comparison with the two-step chemical transformation (both reduction and oxidation), which is required for microbially-produced artemisinic acid (473).

An alternative more radical approach would be to attempt to mimic within the microbial fermentation medium the spontaneous autoxidation reactions of dihydroartemisinic acid (480) which are believed to occur in the glandular trichomes of $A$. annua plants. This would require the inclusion of some kind of hydrophobic phase in intimate association with the fermentation medium. Previously, dodecane has been incorporated into the culture medium, in order to provide a separate hydrophobic layer in which volatile amorpha-4,11-diene (451) produced by microbial fermentation can be trapped $[382,385]$. It would be interesting to investigate whether alternative hydrophobic phases can be found which provide a lipophilic environment similar to that of the glandular trichome, in which spontaneous autoxidation is favoured. (Such a phase would also need to be able to efficiently "trap" dihydroartemisinic acid and to be non-toxic to the fermenting organism). It should be noted that our understanding of how the spontaneous autoxidation of natural products such as $\mathbf{4 8 0}$ occurs in the absence of a photosensitizer [388] (or, indeed, any other additional chemical reagents [218]), leading to highly oxidized products such as $\mathbf{4 9 5}$, is still incomplete. This is a relatively unexplored area which 
requires fundamental research, but the ultimate prize would be the production of artemisinin, both cheaply and reliably, by a single fermentation process, which incorporates an "in-built" spontaneous autoxidation step.

\section{Acknowledgements}

The author gratefully acknowledges the support of the BBSRC (grant no. BB/G008744/1 "The Biosynthesis of Artemisinin") in producing this review.

\section{References}

1. Hsu, E. The history of qing hao in the Chinese materia medica. Trans. R. Soc. Trop. Med. Hyg. 2006, 100, 505-508.

2. Yeung, H.C. Handbook of Chinese Herbs and Formulas; Institute of Chinese Medicine: Los Angeles, CA, USA, 1985; Volume 1, p.430.

3. Anonymous. Pharmacopoeia of the People's Republic of China, English edition ed.; Guangdong Science and Technology Press: Guangzhou, China, 1992; p. 91.

4. Klayman, D.L. Qinghaosu (artemisinin): an antimalarial drug from China. Science 1985, 228, 1049-1055.

5. Luo, X.D.; Shen, C.C. The chemistry, pharmacology, and clinical applications of Qinghaosu (artemisinin) and its derivatives. Med. Res. Rev. 1987, 7, 29-52.

6. Anonymous. Kang nue xin yao qin hao su de yan jiu (in Chinese). Chin. Pharm. Bull. 1979, 2, 49-53.

7. Sriram, D.; Rao, V.S.; Chandrasekhar, K.V.G.; Yogeeswari, P. Progress in the research of artemisinin and its analogues as antimalarials: an update. Nat. Prod. Res. 2004, 18, 503-527.

8. Begue, J.P.; Bonnet-Delpon, D. The future of antimalarials: Artemisinins and synthetic endoperoxides. Drugs Future 2005, 30, 509-518.

9. Brown, G.D.; Liang, G.-Y.; Sy, L.-K. Terpenoids from the seeds of Artemisia annua. Phytochemistry 2003, 64, 303-323.

10. Klayman, D.L.; Lin, A.J.; Acton, N.; Scovili, J.P.; Hoch, J.M.; Milhous, W.K.; Theoharides, A.D. Isolation of artemisinin (Qinghaosu) from Artemisia annua growing in the US. J. Nat. Prod. 1984, 47, 715-717.

11. Balachandran, S.; Vishwakarma, R.A.; Popli, S.P. Chemical investigation of some Artemisia species: Search for artemisinin or other related sesquiterpene lactones with a peroxide bridge. Indian J. Pharm. Sci. 1987, 49, 152-154.

12. Bhakuni, R.S.; Jain, D.C.; Sharma, R.P. Phytochemistry of Artemisia annua and the Development of Artemisinin-Derived Antimalarial Agents. In Artemisia; Wright, C., Ed.; Taylor and Francis: Oxford, UK, 2002; Chapter 12, pp. 211-249.

13. Bhakuni, R.S.; Jain, D.C.; Sharma, R.P.; Kumar, S. Secondary metabolites of Artemisia annua and their biological activity. Curr. Sci. 2001, 80, 35-48.

14. Bhakuni, R.S.; Jain, D.C.; Sharma, R.P. Phytochemistry of Artemisia annua and the development of artemisinin-derived antimalarial agents. Med. Aromat. Plants-Ind. Profiles 2002, 18, 211-248. 
15. Chen, J.; Zhou, Y.-B.; Zhang, X.; Huang, L.; Sun, W.; Wang, J.-H. Chemical constituents of Artemisia annua L. Shenyang Yaoke Daxue Xuebao 2008, 25, 866-870.

16. Buckingham, J., Ed. Introduction to the Type of Compound Index. In Dictionary of Natural Products; Chapman and Hall: London, UK, 2004; Volume 1, pp. xi-lxii.

17. Asahina, Y.; Yoshitomi, E. Essential oil of Artemisia annua L. I. Yakugaku Zasshi 1917, 489.

18. Imada, Y. Volatile Oil of Artemisia annua L. Yakugaku Zasshi 1917, 119-135.

19. Billa, A.R.; Flamini, G.; Morgenni, F.; Isacchi, B.; Franco, F. GC-MS analysis of the volatile constituents of essential oil and aromatic waters of Artemisia annua L. at different developmental stages. Nat. Prod. Comm. 2008, 3, 2075-2078.

20. Ma, C.; Wang, H.; Lu, X.; Xu, G.; Liu, B. Metabolic fingerprinting investigation of Artemisia annua L. in different stages of development by gas chromatography and gas chromatographymass spectrometry. J. Chromatogr. A. 2008, 1186, 412-419.

21. Woerdenbag, H. J.; Bos, R.; Salomons, M. C.; Hendriks, H.; Pras, N.; Malingre, T. M., Volatile constituents of Artemisia annua L. (Asteraceae). Flavour Frag. J. 1993, 8, 131-137.

22. Liu, Q.; Yang, Z.-Y.; Deng, Z.-B.; Sa, G.; Wang, X. Preliminary analysis on chemical constituents of essential oil from inflorescence of of Artemisia annua L. Acta Botanica Sinica (Zhiwu Xuebao) 1988, 30, 223-225.

23. Tian, J.; Feng, W.; He, B. Study on volatile constituents of herba Artemisia annua and its preparation by GC-MS. Shizen Guoyi Guoyao 2007, 18, 1840-1842.

24. Zou, Y.; Shi, J.; Shi, H. Analysis of volatile components from Artemisia annua Linn. Fenxi Ceshi Xuebao 1999, 18, 55-57.

25. Chalchat, J.-C.; Raymond, P.G.; Michet, A.; Gorunovic, M.; Stosic, D. A contribution to chemotaxonomy of Artemisia annua L., Asteraceae. Acta Pharm. Jugosl. 1991, 41, 233-236.

26. Zhong, Y.; Cui, S. Studies of volatile constituents from Artemisia annua. Zhongyao Tongbao 1983, 8, 31-32.

27. Goel, D.; Goel, R.; Singh, V.; Ali, M.; Mallavarapu, G.R.; Kumar, S. Composition of the essential oil from the root of Artemisia annua. J. Nat. Med. 2007, 61, 458-461.

28. Mukhtar, H.M.; Ansari, S.H.; Ali, M.; Mir, S.R.; Abdin, M.Z.; Singh, P. GC-MS analysis of volatile oil of aerial parts of Artemisia annua L. J. Essent. Oil-Bearing Plants 2007, 10, 168-171.

29. Genov, N.; Georgiev, E. Gas-Chromatographic study of the essential oil of Artemisia annua L. Naunchi Trudove - Vissh Institut po Khranitelna i Vkusova Promishlenost, Plodiv 1983, 30, 141-148.

30. Tsankova, E.; Ognyanov, I. On the composition of the essential oil from Artemisia annua Linnaeus. Italiana Essenze, Profumi, Piante Officinale, Aromi, Saponi, Cosmetici, Aerosol 1976, 58, 502-504.

31. Ma, C.; Wang, H.; Lu, X.; Li, H.; Liu, B.; Xu, G. Analysis of Artemisia annua L. volatile oil by comprehensive two-dimensional gas chromatography time-of-flight mass spectrometry. $J$. Chromatogr. A. 2007, 1150, 50-53.

32. Goel, D.; Singh, V.; Ali, M.; Mallavarapu, G.R.; Kumar, S. Essential oils of petal, leaf and stem of the antimalarial plant Artemisia annua. J. Nat. Med. 2007, 61, 187-191.

33. Libbey, L.M. Unusual essential oils grown on Oregon II. Artemisia annua L. J. Essent. Oil Res. 1989, 1, 201-202. 
34. Ali, M.; Siddiqui, N.A. Volatile oil constituents of Artemisia annua leaves. J. Med. Aromat. Plant Sci. 2000, 22, 568-571.

35. Nakajima, V.T. Essential Oils of Artemisia annua. Yakugaku Zasshi 1962, 82, 1323-1326.

36. Biougne, J.; Chalchat, J.-C.; Garry, R.P.; Lamy, J. Essential oil of Artemisia annua: Seasonal variations in chemical composition. Rivista Italiania EPPOS 1993, 4, 622-629.

37. Holm, Y.; Laasko, I.; Hitunen, R.; Galambosi, B., Variation in the essential oil composition of Artemisia annua L. of different origin cutivated in Finland. Flavour Frag. J. 1997, 12, 241-246.

38. Hethelyl, E.B.; Cseko, I.B.; Grosz, M.; Mark, G.; Palinkos, J.J. Chemical composition of the Artemisia annua essential oils from Hungary. J. Essent. Oil Res. 1995, 7, 45-48.

39. Popescu, H.; Tamas, M.L.; Tibori, A.G. Artemisia annua: An indigenous source of volatile oil. Clujul Med. 1980, 53, 331-337.

40. Dembitskii, A.D.; Krotova, G.I.; Kuchukhidze, N.M.; Yakobashvili, N.Z. Essential Oil of Artemisia annua L. Maslozhirovaya Promyshlennost 1983, 31-34.

41. Verdian-Rizi, M.R.; Sadat-Ebrahimi, E.; Hadjakhoondi, A.; Fazeli, M.R.; Pirali, H.M. Chemical composition and antimicrobial activity of Artemisia annua L. essential oil from Iran. Fasinmah-i Giyahan-i-Daruyi 2008, 7, 58-62.

42. Lari, Y.H.; Khavarinejad, R.A.; Roustalan, A.H. The composition of essential oil from Artemisia annua L. growing wild in Iran. Falsnamah-i-Giyahan-i Daruyi 2002, 1, 41-48.

43. Goel, D.; Mallavarupu, G.R.; Kumar, S.; Singh, V.; Ali, M. Volatile metabolite composition of the essential oil from aerial parts of ornamanetal and artemisinin-rich cultivars of Artemisia annua. J. Essent. Oil Res. 2007, 20, 147-152.

44. Bagchi, G.D.; Haider, F.; Dwivedi, P.D.; Singh, A.; Naqvi, A.A. Essential oil constituents of Artemisia annua during different growth periods at monsoon conditions of subtropical North Indian plants. J. Essent. Oil Res. 2003, 15, 59-62.

45. Jain, N.; Srivastava, S.K.; Aggarawal, K.K.; Kumar, S.; Syamasundar, K.V. Essential oil composition of Artemisia annua L. "Asha" from the plains of Northern India. J. Essent. Oil Res. 2002, 14, 305-307.

46. Yang, Z.; Yu, Z.; Luo, S.; Peng, Q. Investigation of essential oil from leaves of Artemisia annua L. in Guizhou. Shizen Guoyi Guoyao 2008, 19, 255-257.

47. He, B.; Feng, W.-Y.; Tian, J.; Li, C.-H.; Ai, H.-B. Analysis of chemical composition of voatile oil in Youyang Artemisia annua by GC-MS. Huaxi Yaoxue Zazhi 2008, 23, 30-31.

48. Li, R.; Wang, D.; Liao, H. Chemical constituents of essential oil from the fruits of Artemisia annua L. Zhongnan Yaoxue 2007, 5, 230-232.

49. Sun, Y.; Chen, X.; Zhang, H.; Xu, X.; Li, P. GC determination of eucalyptol, artemisia ketone, camphor, caryophyllene and caryophyllene oxide in Artemisia annua L. produced in Sichuan. Yaowu Fenxi Zazhi 2006, 26, 239-241.

50. Zhang, Y.; Zhang, J.; Yao, J.; Wang, L.; Huang, A.-L.; Dong, L.-N. Studies on the chemical composition of the essential oil of Artemisia annua L. from Xinjiang. Xibei Shifan Daxue Xuebao, Ziran Kexueban 2004, 40, 67-69.

51. Nguyen, X.D.; Leclercq, P.A.; Dinh, H.K.; Nguyen, M.T. Chemical Composition of essential oil of Vietnamese Artemisia annua L. Tap Chi Duoc Hoc 1990, 11-13. 
52. Pham, G.D. Chemical components of the essential oil of Artemisia annua L. in Vietnam and Bulgaria. Tap Chi Duoc Hoc 2003, 11-12.

53. Charles, D.J.; Cebert, E.; Simon, J.E. Characterization of the essential oil of Artemisia annua L. J. Essent. Oil Res. 1991, 3, 33-39.

54. Tellez, M.R.; Canel, C.; Duke, S.O.; Rimando, A. Comparison of the essential oil of Artemisia annua L. and a chemotype of A. annua L. without glandular trichomes. Book of Abstracts; In proceedings of 216th ACS National Meeting, Boston, MA, USA, August 23-27, 1998.

55. Woerdenbag, H.J.; Pras, N.; Bos, R.; Visser, J.F.; Hendriks, H.; Malingre, T.M. Analysis of artemisinin and related sesquiterpenes from Artemisia annua L. by combined gas chromatography/mass spectrometry. Phytochem. Analysis 1991, 2, 215-219.

56. Tian, Y.; Wei, Z.; Wu, Z. Studies on the chemical constituents of Qinghao (Artemisia annua), a traditional chinese herb. Zhongcaoyao 1982, 13, 9-11.

57. Szeto, Y.-T.; Benzie, I. F.-F. Is the yin-yang nature of Chinese herbal medicine equivalent to antioxidation-oxidation? J. Ethnopharmacol. 2006, 108, 361-366.

58. Ululeben, A.; Halfon, B. Phytochemical investigation of the herb of Artemisia annua. Planta Med. 1976, 29, 258-260.

59. Khan, M.M.A.A.; Jain, D.C.; Bhakuni, R.S.; Zaim, M.; Thakur, R.S. Occurrence of some antiviral sterols in Artemisia annua. Plant Sci. 1991, 75, 161-166.

60. Singh, T.; Bhakuni, R.S. A new sesquiterpene lactone from Artemisia annua leaves. Indian J. Chem. Sect. B: Organic Chemistry including Medicinal Chemistry 2004, 43B, 2734-2736.

61. Tu, Y.; Zhu, Q.; Shen, X. Constituents of young Artemisia annua. Zhongyao Tongbao 1985, 10, 419-20.

62. Bhakuni, R.S.; Jain, D.C.; Shukla, Y.N.; Thakur, R.S. Lipid constituents from Artemisia annua. J. Indian Chem. Soc. 1990, 67, 1004-1006.

63. Ul'chenko, N.T.; Khushbaktova, Z.A.; Bekker, N.P.; Kidisyuk, E.N.; Syrov, V.N.; Glushenkov, A.I. Lipids from flowers and leaves of Artemisia annua and their biological activity. Chem. Nat. Comp. 2005, 41, 280-284.

64. Zhang, J.; Zhang, Y.; Zhang, H.-B.; Wang, Y.-F.; Yao, J. Studies on the composition of the fatty acids of five species of Artemisia in Xinjiang. Xibei Shifan Daxue Xuebao, Ziran Kexueban 2004, 40, 64-67.

65. Deng, S.-J.; Li, C.-Y.; Chen, S.; He, X.-X.; Gu, W.-X.; Gao, Z.-M. Alleochemicals isolation and structure identification of Artemisia annua. Huanan Nongye Daxue Xuebao 2008, 29, 42-46.

66. Ahmad, A.; Misra, L.N. Terpenoids from Artemisia annua and constituents of its essential oil. Phytochemistry 1994, 37, 183-186.

67. Manns, D.; Hartmann, R. Annuadiepoxide, a new polyacetylene from the aerial parts of Artemisia annua. J. Nat. Prod. 1992, 55, 29-32.

68. Brown, G. D. Two new compounds from Artemisia annua. J. Nat. Prod. 1992, 55, 1756-1760.

69. Chen, Y.; You, B.; Dong, L.; Zhou, L. Isolation and identification of arteannuin and its precursor. Zhongcaoyao 2001, 32, 302-303.

70. Singh, A.K.; Pathak, V.; Agrawal, P.K. Annphenone, a phenolic acetophenone from Artemisia annua. Phytochemistry 1997, 44, 555-557 
71. Han, J.; Ye, M.; Qiao, X.; Xu, M.; Wang, B.-R.; Guo, D.-A. Characterization of phenolic compounds in the Chinese herbal drug Artemisia annua by liquid chromatography coupled to electrospray ionization mass spectrometry. J. Pharm. Biomed. Anal. 2008, 47, 516-525.

72. Georgiev, E.; Genov, N. Changes in the essential oil of Artemisia annua L. during storage. Nauchni Trudove - Vissh Institut po Khranitelna i Vkusova Promishlenost 1983, 30, 149-160.

73. Georgiev, E.; Genov, N.; Lazarova, R.; Ganchev, G. On the distillation of annual wormwood (Artemisia annua Linnaeus). Rivista Italiana Essenze, Profumi, Piante Officinali, Arromatizanti, Syndets, Saponi, Cosmaetici, Aerosols 1978, 60, 302-306.

74. Perazzo, F.F.; Carvalho, J.C.T.; Carvalho, J.E.; Rehder, V.L.G. Central properties of the essential oil and the crude ethanol extract from aerial parts of Artemisia annua L. Pharmacol. Res. 2003, 48, 497-502.

75. Tu, Y.-Y.; Yin, J.-P.; Ji, L.; Huang, M.-M; Liang, X.-T. Chemical constituents of sweet wormwood (Artemisia annua) (III). Zhongcaoyao 1985, 16, 200-201.

76. Shilin, Y.; Roberts, M.F.; Phillipson, J.D. Methoxylated flavones and coumarins from Artemisia annua. Phytochemistry 1989, 28, 1509-1512.

77. Liu, H.-M.; Li, K.-L.; Wo, W.-C. Studies on the constituents of Artemisia annua. Yaoxue Tongbao 1980, 15, 39.

78. Htut, Z.W. Artemisinin resistance in Plasmodium falciparum malaria. New Engl. J. Med. 2009, 361, 1807-1808.

79. Saitibaeva, I.M. Coumarins from Artemisia annua. Khim. Prir. Soedin. 1970, 6, 758.

80. Pham, G.D. Coumarin and its derivatives in Artemisia annua L. in Vietnam. Tap Chi Duoc Hoc 2002, 11-13.

81. Djermanovic, M.; Stepanovic, M.; Djermanovic, V.; Milovanovic, M. Some new constituents from domestic plant species of Artemisia monogyna $\mathrm{W}$ and $\mathrm{K}$ and Artemisia annua L. J. Serb. Chem. Soc. 1997, 62, 113-116.

82. Tzeng, T.-C.; Lin, Y.-L.; Jong, T.-T.; Chang, C.-M.J. Ethanol modified supercritical fluid extraction of scopoletin and artemisinin from Artemisia annua L. Sep. Purif. Technol. 2007, 56, $18-24$.

83. Yang, L.; Wang, M.-Y.; Zhang, D.; Tu, Y. Determination of scopoletin in Artemisia annua by HPLC. Zhongguo Shiyan Fangjixue Zazhi 2006, 12, 10-11.

84. Marco, J.A.; Sanz, J.F.; Bea, J.F.; Barbera, O. Phenolic constituents of Artemisia annua. Pharmazie 1990, 45, 382-383.

85. Nguyen, V.B.; Do, D.R.; Nguyen, G.C.; Bui, T.B.; Chu, D.K. Research on the extraction of a coumarin derivative from the leaves of Artemisia annua L. growing in Vietnam. Tap Chi Duoc Hoc 1998, 36, 58-61.

86. Brown, G.D. Secondary metabolism in tissue culture of Artemisia annua. J. Nat. Prod. 1994, 57, 975-977.

87. Sy, L.-K.; Brown, G.D. Coniferaldehyde derivatives from tissue culture of Artemisia annua and Tanacetum parthenium. Phytochemistry 1999, 50, 781-785.

88. Aleskerova, A.N. Detection of esculetin in Artemisia annua L. Izvestiya Akademii Nauk Azerbaidzhanskoi SSR Seriya Bioligicheskikh Nauk 1985, 25-26. 
89. Yang, S.L.; Roberts, M.F.; O'Neill, M.J.; Bucar, F.; Phillipson, J.D. Flavonoids and chromenes from Artemisia annua. Phytochemistry 1995, 38, 255-257.

90. Agarwal, P.K.; Singh, A.K.; Bhakuni, R.S.; Jain, D.C. Studies on medicinal plants. 43. Characterization of a coumarin from Artemisia annua: Correlation of assigned chemical shifts with its hydrated form. Curr. Res. Med. Aromat. Plants 1995, 17, 321-325.

91. Elford, B.C.; Roberts, M.F.; Philipson, J.D.; Wilson, R.J.M. Potentiation of the antimalarial activity of qinghaosu by methoxylated flavones. Trans. R. Soc. Trop. Med. Hyg. 1987, 81, 434436.

92. Stermitz, F.R.; Scriven, L.N.; Tegos, G.; Lewis, K. Two flavanols from Artemisia annua which potentiate the activity of berberine and norfloxacin against a resistant strain of Staphylococcus aureus. Planta Med. 2002, 68, 1140-1141.

93. Baraldi, R.; Isacchi, B.; Predieri, S.; Marconi, G.; Vincieri, F.F.; Anna, R. Distribution of artemisinin and bioactive flavonoids from Artemisia annua L. during plant growth. Biochemical Syst. Ecol. 2008, 36, 340-348.

94. Yang, S.; Roberts, M.F.; Philipson, J.D. Methoxylated flavones and coumarins from Artemisia annua. Phytochemistry 1989, 28, 1509-1511.

95. Liu, K.C.S.C.; Yang, S.L.; Roberts, M.F.; Elford, B.C.; Phillipson, J.D. Antimalarial activity of Artemisia annua flavonoids from whole plants and cell cultures. Plant Cell Rep. 1992, 11, 637-640.

96. Tang, H.-Q.; Hu, J.; Yang, L.; Tan, R.-X. Terpenoids and flavonoids from Artemisia species. Planta Med. 2000, 66, 391-393.

97. Sy, L.-K.; Brown, G.D. Three sesquiterpenes from Artemisia annua. Phytochemistry 1998, 48, 1207-1211.

98. Bilia, A.R.; de Malgalhaes, P.M.; Bergonzi, M.C.; Vincieri, F.F. Simultaneous analysis of artemisinin and flavonoids of several extracts of Artemisia annua L. obtained from a commercial sample and a selected cultivar. Phytomedicine 2006, 13, 487-493.

99. Jeremic, D.; Stefanovic, M.; Dokovic, D.; Milosavljevic, S. Flavonols from Artemisia annua. Glas. Khem. Drush. Beograd. 1979, 44, 615-618.

100. Baeva, R.T.; Nabi-Zade, L.I.; Zapesochnaya, G.G.; Karryev, M.O. Flavonoids of Artemisia annua. Khim. Prir. Soedin. 1988, 298-299.

101. Bhardwaj, D.K.; Jain, R.K.; Jain, S.C.; Manchanda, C.K. Constituents of Artemisia annua. Proc. Indian Nat. Sci. Acad. 1985, 51A, 741-745.

102. Schramek, N.; Wang, H.; Roemisch-Margl, W.; Keil, B.; Radykewicz, T.; Winzenhoerlein, B.; Beerhuse, L.; Bacher, A.; Rodich, F.; Gershenzon, J.; Liu, B.; Eisenreich, W. Artemisinin biosynthesis in growing plants of Artemisia annua. A ${ }^{13} \mathrm{CO}_{2}$ study. Phytochemistry. 2010, 71, 179-187.

103. Han, X.; Ma, X.; Zhang, T.; Zheng, Y.; Liu, Q.; Ito, Y. Isolation of high-purity casticin from Artemisia annua L. by high-speed counter-current chromatography. J. Chromatogr. A. 2007, 1151, 180-182.

104. Olsson, M.E.; Olofsson, L.M.; Lindahl, A.-L.; Lundgren, A.; Brodelius, M.; Brodelius, P.E. Localization of enzymes of artemisinin biosynthesis to the apical cells of glandular secretory trichomes of Artemisia annua L. Phytochemistry 2009, 70, 1123-1128. 
105. Zheng, G.-Q. Cytotoxic terpenoids and flavonoids from Artemisia annua. Planta Med. 1994, 60, 54-57.

106. Liu, H.-M.; Li, G.-L.; Wu, H.-Z. Studies on the chemical constituents of Artemisia annua L. Yaохие Xuebao (Acta Pharmaceutica Sinica) 1981, 16, 65-67.

107. Djermanovic, M.; Jokic, A.; Mladenovic, S.; Stefanovic, M. Quercetagetin 6,7,3',4'-tetramethyl ether, a new flavonol from Artemisia annua. Phytochemistry 1975, 14, 1873.

108. Tellez, M.R.; Canel, C.; Rimando, A.M.; Duke, S.O. Differential accumulation of isoprenoids in glanded and glandless Artemisia annua L. Phytochemistry 1999, 52, 1035-1040.

109. Banthorpe, D.V.; Christou, P.N.; Pink, C.R.; Watson, D.G. Metabolism of linaloyl, neryl and geranyl pyrophosphates in Artemisia annua. Phytochemistry 1983, 22, 2465-2468.

110. Jia, J.-W.; Crock, J.; Lu, S.; Croteau, R.; Chen, X.-Y. (3R)-Linalool synthase from Artemisia annua L: cDNA isoation, characterization and wound induction. Arch. Biochem. Biophys. 1999, 372, 143-149.

111. Lawrence, B. M., Progress in Essential Oils. Perfum. Flavor. 1982, 7, 43-44.

112. Georgiev, E.; Genov, N.; Khristova, N. Changes in yield and quality of essential oil in annual wormwood (Artemisia annua L.) during growth. Rastenievundi Nauki 1981, 18, 95-102.

113. Yakobashvili, N.Z.; Kuchukhidze, N.M.; Chikvanya, V.E. Fractionation of sweet wormwood oil. Maslozhirovaya Promyshlennost 1981, 28-29.

114. Ruecker, G.; Mayer, R.; Manns, D. $\alpha$ - and $\beta$-Myrcene hydroperoxide from Artemisia annua. J. Nat. Prod. 1987, 50, 287-289.

115. Asahina, Y.; Takagi, S. Report on the essential oil of Artemisia annua L. II. Constitution of artemisia ketone. Yakugaku Zasshi 1920, 837-864.

116. Ruzicka, L.; Reichstein, T.; Pulver, R. Synthesis of tetrahydroartemisia ketone. Helv. Chim. Acta 1936, 19, 646-649.

117. Takemoto, T.; Nakajima, T. Essential oil of Artemisia annua. I. Isolation of a new ester compound. Yakugaku Zasshi 1957, 77, 1307-1309.

118. Takemoto, T.; Nakajima, T. Essential oil of Artemisia annua. II. Structure of 1- $\beta$-artemisia alcohol. Yakugaku Zasshi 1957, 77, 1310-1313.

119. Takemoto, T.; Nakajima, T. Essential oil of Artemisia annua. III. Structure of artemisia ketone. Yakugaku Zasshi 1957, 77, 1339-1344.

120. Takemoto, T.; Nakajima, T. Essential oil of Artemisia annua. IV. Dihydroartemisia ketone. Yakugaku Zasshi 1957, 77, 1344-1347.

121. Hethelyl, I.; Ceseko, I.; Grosz, M.; Mark, G.; Palinkas, J. Capillary gas chromatographic investigation of Artemisia annua essential oils. Olaj, Szappan, Kozmetika 1994, 43, 103-106.

122. Suga, T.; Shishibori, T.; Kotera, K.; Fujii, R. Biosynthesis of a non-head-to-tail monoterpene, artemisia ketone. Chem. Lett. 1972, 7, 533-534.

123. Simpson, J.B. On the Biosynthesis of Artemisia Ketone in Artemisia annua; Louisiana State Univ.: Baton Rouge, LA, USA, 1979; p. 135.

124. Banthorpe, D.V.; Charlwood, B.V.; Greaves, G.M.; Voller, C.M. Terpene biosynthesis. Part 20. Role of geraniol and nerol in the biosynthesis of artemisia ketone. Phytochemistry 1977, 16, 1387-1392. 
125. Risinger, G.E.; Karimian, K.; Jungk, S.; Simpson, J.B. On the biosynthesis of artemisia ketone and bakuchiol. Experientia 1978, 34, 1121-1122.

126. Allen, K.G.; Banthorpe, D.V.; Charlwood, B.V.; Voller, C.M. Terpene biosynthesis. Part 17. Biosynthesis of irregular monoterpenes in extracts from higher plants. Phytochemistry 1977, 16, 85-92.

127. Banthorpe, D.V.; Charlwood, B.V. Biosynthesis of artemisia ketone. Nature (London), New Biol. 1971, 231, 285-286.

128. Boulton, K.; Shirley, I.; Smith, I.H.; Whiting, D.A. Mechanism of formation of natural cyclopropanes: Synthesis of postulated intermediates in presqualene and chrysanthemyl alcohol biosynthesis. J. Chem. Soc. Perkin Trans. I 1986, 1817-1824.

129. Sy, L.-K.; Brown, G.D. Deoxyarteannuin B, dihydro-deoxyarteannuin B and trans-5-hydroxy-2isopropenyl-5-methylhex-3-en-1-ol from Artemisia annua. Phytochemistry 2001, 58, 1159-1166.

130. Youann, T. Essential oil of Artemisia annua. Perfumery and Essential Oil Rec. 1955, 46, 75-78.

131. Lu, S.; Xu, R.; Jia, J.-W.; Pang, J.; Matsuda, S.P.T.; Chen, X.-Y. Cloning and functional characterization of a $\beta$-pinene synthase from Artemisia annua that shows a circadian pattern of expression. Plant Physiol. 2002, 130, 477-486.

132. Tu, Y.-Y.; Liang, X.-T. Studies on the constituents of Artemisia annua. Yaoxue Xuebao (Acta Pharmaceutica Sinica) 1981, 16, 366-369.

133. Picaud, S.; Brodelius, M.; Brodelius, P.E. Expression, purification and characterization of recombinant (E)- $\beta$-farnesene synthase from Artemisia annua. Phytochemistry 2005, 66, 961-967.

134. Picaud, S.; Olofsson, L.; Brodelius, M.; Brodelius, P.E. Expression, purification and characterization of recombinant amorpha-4,11-diene synthase from Artemisia annua L. Arch. Biochem. Biophys. 2005, 436, 215-226.

135. Bertea, C.M.; Freije, J.R.; van der Woude, H.; Verstappen, F.W.A.; Perk, L.; Marquez, V.; De Kraker, J.-W.; Posthumus, M.A.; Jansen, B.J.M.; de Groot, A.; Franssen, M.C.R.; Bouwmeester, H.J. Identification of intermediates and enzymes involved in early steps of artemisinin biosynthesis in Artemisia annua. Planta Med. 2005, 71, 40-47.

136. Picaud, S.; Mercke, P.; He, X.; Sterner, O.; Brodelius, M.; Cane, D.E.; Brodelius, P.E. Amorpha4,11-diene synthase: mechanism and stereochemistry of the enzymatic cycization of farnesyl diphosphate. Arch. Biochem. Biophys. 2006, 448, 150-155.

137. Bertea, C.M.; Voster, A.; Verstappen, F.W.A.; Maffei, M.; Beekwilder, J.; Bouwmeester, H.J. Isoprenoid biosynthesis in Artemisia annua: cloning and heterologous expression of a germacrene A synthase from a glandular trichome cDNA library. Arch. Biochem. Biophys. 2006, 448, 3-12.

138. Kong, J. Q.; Huang, Y.; Shen, J.; Wang, W.; Cheng, K.; Zhu, P. Recent advances in the study of amorpha-4,11-diene synthase and its metabolic engineering. Yaохиe Xuebao 2009, 44, 1320-1327.

139. Cai, Y.; Jia, J.-W.; Crock, J.; Lin, Z.-X.; Chen, X.-Y.; Croteau, R. A cDNA clone for $\beta$ caryophyllene synthase from Artermisia annua. Phytochemistry 2002, 61, 523-529.

140. Liu, Y.-M.; Pu, X.-F.; Zhang, L. Determination of camphor and caryophyllene in Artemisia annua L. and Herba artemisiae annuae oil by capillary GC. Huaxue Yaoxue Zashi 2007, 22, 218-220. 
141. Bolt, A.J.N.; Cocker, W.; McMurray, T.B.H. The stereochemistry of artemisin. J. Chem. Soc. 1963, 5235-5238.

142. Pinhey, J.T.; Sternhell, S. Structure of $\alpha$-hydroxysantonin and some aspects of the stereochemistry of related eudesmanolides and guaianolides. Aust. J. Chem. 1995, 18, 543-547.

143. Zhu, D.; Zhang, S.; Liu, B.; Fan, G.; Liu, J.; Xu, R. Study on antibacterial constituents of Qing Hao (Artemisia annua L.). Zhongcaoyao 1982, 13, 6.

144. Zhou, W.; Xu, X. Synthesis of arteannuin and related compounds. Yiyao Gongye 1987, 18, 470-477.

145. Agrawal, P.K.; Bishnoi, V. NMR spectral investigations. Part 41. Sesquiterpenoids from Artemisia annua: ${ }^{13} \mathrm{C}$ NMR shielding behavior. J. Sci. Ind. Res. 1996, 55, $17-26$.

146. Marsaioli, A.J.; Fujiwara, F.Y.; Foglio, M.A.; Sharapin, N.; Zhang, J.-S. Proton and carbon-13 NMR and conformation in solution of some amorphanes (Qinghaosu derivatives). Mag. Res. Chem. 1994, 32, 583-90.

147. Tu, Y.-Y.; Ni, M.-Y.; Zhong, Y.-R.; Li, L.-N.; Cui, S.-L.; Zhang, M.-Q.; Wang, X.-Z.; Ji, Z.; Liang, X.-T. Studies on the constituents of Artemisia annua: 2. Planta Med. 1982, 44, 143-145.

148. Misra, L.N.; Ahmad, A.; Thakur, R.S.; Lotter, H.; Wagner, H. Crystal structure of artemisinic acid: A possible biogenetic precursor of antimalarial artemisinin from Artemisia annua. J. Nat. Prod. 1993, 56, 215-219.

149. Jeremic, D.; Jokic, A.; Behbud, A.; Stefanovic, M. New type of sesquiterpene lactone isolated from Artemisia annua. Arteannuin B. Tetrahedron Lett. 1973, 3039-42.

150. Liu, J.-M.; Ni, M.-Y.; Fan, J.-F.; Tu, Y.-Y.; Wu, Z.-H.; Wu, Y.-L.; Chou, W.-S. Structure and reaction of arteannuin. Ниахие Хиеbao 1979, 37, 129-143.

151. Tu, Y.-Y.; Ni, M.-Y.; Chung, Y.-Y.; Li, L.-N. Chemical constituents in Artemisia annua L. and the derivatives of artemisinin. Chung Yao Tong Pao 1981, 6, 31.

152. Pang, G.; Kenzo, H.; Yoichi, I.; Seiichi, I. Study on the absolute configuration of artemisinic acid isolated from chinese antimalaria herb Artemisia annua L. Shenyang Yaoke Daxue Xuebao 1997, 14, 189-195.

153. Kim, S.-U.; Han, J.; Lim, Y.-H. Revised assignment of ${ }^{1} \mathrm{H}-\mathrm{NMR}$ signals of artemisinic acid. Planta Med. 1996, 62, 480-481.

154. Zhou, W.-S. Studies on the structure and synthesis of arteannuin and related compounds. Huaxue Xuebao 1989, 47, 710-715.

155. Brown, G.D.; Sy, L.-K. In vivo transformations of artemisinic acid in Artemisia annua plants. Tetrahedron 2007, 63, 9548-9566.

156. Roth, R.J.; Acton, N. A simple conversion of artemisinic acid into artemisinin. J. Nat. Prod. 1989, 52, 1183-1185.

157. Haynes, R.K.; Vonwiller, S.C. The Development of new peroxide antimalarials. Chem. Aust. 1991, 58, 64-67.

158. Jung, M.; Yoo, Y.; Elsohly, H.N.; McChesney, J.D. One-step stereospecific synthesis of (-)arteannuin B. J. Nat. Prod. 1987, 50, 972-973.

159. Xu, X.; Zhu, J.; Zhou, W. Stereoselective synthesis of arteannuin B. Kexue Tongbao 1982, 27, 1022. 
160. El-Feraly, F.S.; Al-Meshal, I.A.; Khalifa, S.I. epi-Deoxyarteannuin B and 6,7-dehydroartemisinic acid from Artemisia annua. J. Nat. Prod. 1989, 52, 196-198.

161. Acton, N.; Roth, R.J. Synthesis of epi-deoxy- and deoxyarteannuin B. Phytochemistry 1989, 28, 3530-3531.

162. Kim, S.-U. Efficient conversion of arteannuic acid into epi-deoxyarteannuin B. Han'guk Nonghwa Hakhoechi 1990, 33, 174-176.

163. Roth, R.J.; Acton, N. Isolation of epi-deoxyarteannuin B from Artemisia annua. Planta Med. 1987, 53, 576.

164. Roth, R.J.; Acton, N. Isolation of arteannuic acid from Artemisia annua. Planta Med. 1987, 53, 501-502.

165. Sy, L.-K.; Brown, G.D. Synthesis of 6,7-dehydroartemisinic acid. J. Chem. Soc. Perkin Trans. 1 2002, 2421-2429.

166. Sy, L.-K.; Brown, G.D.; Haynes, R. A novel endoperoxide and related sesquiterpenes from Artemisia annua which are possibly derived from allylic hydroperoxides. Tetrahedron 1998, 54, 4345-4356.

167. Wallaart, E.T.; van Uden, W.; Lubberink, H.G.M.; Woerdenbag, H.J.; Prass, N.; Quax, W.J. Isolation and identification of dihydroartemisinic acid from Artemisia annua and its possible role in the biosynthesis of artemisinin. J. Nat. Prod. 1999, 62, 430-433.

168. Brown, G.D.; Sy, L.-K. Synthesis of labelled dihydroartemisinic acid. Tetrahedron 2004, 60, 1125-1138.

169. Sy, L.-K.; Zhu, N.-Y.; Brown, G.D. Synthesis of dihydroartemisinic acid and dihydro-epideoxyarteannuin $\mathrm{B}$ incorporating a stable isotope label at the 15-position for studies into the biosynthesis of artemisinin. Tetrahedron 2001, 57, 8495-8510.

170. Wallaart, T.E.; Pras, N.; Quax, W.J. Isolation and identification of dihydroartemisinic acid hydroperoxide from Artemisia annua: A novel biosynthetic precursor of artemisinin. J. Nat. Prod. 1999, 62, 1160-1162.

171. Zhou, W.-S. Total synthesis of arteannuin (Quinghaosu) and related compounds. Pure Appl. Chem. 1986, 58, 817-824.

172. Zhou, W.; Zhang, L.; Xu, X. Studies on the structure and syntheses of arteannuin and related compounds XVIII. Synthesis of arteannuin A. Нuaxue Xuebao 1986, 44, 968-970.

173. Yusupova, I.M.; Tashkhodzhaev, B.; Mallabaev, A. Molecular structure of the sesquiterpene lactone arteannuin B. Khim. Prir. Soedin. 1986, 6, 788-790.

174. Leppard, D.G.; Rey, M.; Dreiding, A.S.; Grieb, R. The structure of arteannuin B and its acid hydrolysis product. Helv. Chim. Acta 1974, 57, 602-615.

175. Agrawal, P.K.; Vishwakarma, R.A.; Jain, D.C.; Roy, R. High field NMR spectroscopic studies of arteannuin B and a reappraisal of the structure of arteannuin C. Phytochemistry 1991, 30, 3469-3471.

176. Stefanovic, M.; Solujic, S.; Jeremic, D.; Jokic, A.; Miljkovic, D.; Velimirovic, S. Chemical transformations of arteannuin B - cadinane sesquiterpenic lactone - isolated from Artemisia annua L. Glas. Khem. Drus., Beograd 1977, 42, 227-236.

177. Lansbury, P.T.; Mojica, C.A. Total synthesis of (+/-)-arteannuin B. Tetrahedron Lett. 1986, 27, 3967-3970. 
178. Pajarin, M.; Mojica, C.A. The total synthesis of (+/-)-arteannuin B. Diss. Abstr. Int. 1987, 48, 444.

179. Goldberg, O.; Deja, I.; Rey, M.; Dreiding, A.S. The synthesis of stereoisomers of arteannuin B. Helv. Chim. Acta 1980, 63, 2455-2468.

180. Misra, L.N. Arteannuin C, a sesquiterpene lactone from Artemisia annua. Phytochemistry 1986, 25, 2892-2893.

181. Zhou, W.-S.; Zhang, L.; Xu, X.-X. Studies on the structures and synthesis of arteannuin and related compounds XVI. Synthesis of arteannuin E and epoxy fission reaction of methyl $\alpha$-epoxy arteannuate. Ниахие Хиеbao 1985, 43, 845-851.

182. Zhu, D.; Deng, D.; Zhang, S.; Xu, R. The structure of artemisilactone. Huaxue Xuebao 1984, 42, 937-939.

183. Sy, L.-K.; Ngo, K.-S.; Brown, G.D. Biomimetic synthesis of arteannuin H and the 3,2rearrangement of allylic hydroperoxides. Tetrahedron 1999, 55, 15127-15140.

184. Sy, L.-K.; Cheung, K.-K.; Zhu, N.-Y.; Brown, G.D. Structure Elucidation of arteannuin O, a novel cadinane diol from Artemisia annua and the synthesis of arteannuins K, L, M and O. Tetrahedron 2001, 57, 8481-8493.

185. Brown, G.D.; Sy, L.-K. In vivo transformations of dihydroartemisinic acid in Artemisia annua plants. Tetrahedron 2004, 60, 1139-1159.

186. Barriault, L.; Deon, D.H. Recent progress towards the total synthesis of arteannuin M. Abstracts of Papers; In Proceedings of 221st ACS national Meeting, San Diego, CA, USA, April 1-5, 2001.

187. Barriault, L.; Deon, D.H. Total Synthesis of (+)-arteannuin M using the tandem Oxy-Cope/ene reaction. Org. Lett. 2001, 3, 1925-1927.

188. Engel, D.A.; Lam, H.T.C.; Singletary, J.A.; Poon, K.W.C.; Dudley, G.B. Synthetic approaches to artemisinin-related natural products, dihydroartemisinic acid and arteannuin M. Abstracts of Papers; In Proceedings of 231st ACS national Meeting, Atlanta, GA, USA, March 26-30, 2006.

189. Brown, G.D. ${ }^{13} \mathrm{C}-{ }^{2} \mathrm{H}$ correlation NMR spectroscopy studies of the in vivo transformations of natural products from Artemisia annua. Phytochem. Rev. 2003, 2, 45-59.

190. Brown, G.D.; Sy, L.-K. In vivo transformations of dihydro-epi-deoxyarteannuin B in Artemisia annua plants. Tetrahedron 2007, 63, 9548-9566.

191. Dudley, G.B.; Engel, D.A.; Ghiviriga, I.; Lam, H.; Poon, K.-W.C.; Singletary, J.A. Synhesis of (+)-dihydro-epi-deoxyarteannuin B. Org. Lett. 2007, 9, 2839-2842.

192. Engel, D.A.; Lam, H.T.C.; Singletary, J.A.; Poon, K.-W.C.; Dudley, G.B. Synthetic approaches to artemisinin-related natural products, didesmethylartemisinin and dihydro-epi-deoxyarteannuin B. Abstracts of Papers; In Proceedings of 235th ACS national Meeting, New Orleans, LA, USA, April 6-10, 2008.

193. Sy, L.-K.; Brown, G.D. The mechanism of the spontaneous autoxidation of dihydroartemisinic acid. Tetrahedron 2002, 58, 897-908.

194. Wu, Z.; Wang, Y. Structure and synthesis of arteannuin and related compounds. XI, Identification of epoxyarteannuic acid. Huaxue Xuebao 1984, 42, 596-598.

195. Graham, I.A.; Besser, K.; Blumer, S.; Branigan, C.A.; Czechowski, T.; Elias, L.; Guterman, I.; Harvey, D.; Issac, P.G.; Khan, A.M.; Larson, T.R.; Li, Y.; Pawson, T.; Penfield, T.; Rae, A.M.; 
Rathbone, D.A.; Reid, S.; Ross, J.; Smallwood, M.F.; Segura, V.; Townsend, T.; Vyas, D.; Winza, T.; Bowles, D. The genetic map of Artemisia annua L. identifies loci affecting yield of the antimalarial drug artemisinin. Science 2010, 327, 328-331.

196. Teoh, K.T.; Polichuk, D.R.; Reed, D.W.; Nowak, G.; Covello, P. Artemisia annua L. (Asteraceae) trichome-specific cDNAs reveal CYP71AV1, a cytochrome $\mathrm{P}_{450}$ with a key role in the biosynthesis of the antimalarial sesquiterpene lactone artemisinin. FEBS Lett. 2006, 580, 1411-1416.

197. Brown, G.D. Annulide, a sesquiterpene lactone from Artemisia annua. Phytochemistry 1993, 32 , 391-393.

198. Pham, G.D. Terpenoid compounds in leaves of Artemisia annua L. in Vietnam. Tap Chi Duoc Hoc 2002, 5-7.

199. Misra, L.N.; Ahmad, A.; Thakur, R.S.; Jakupovic, J. Bisnorcadinanes from Artemisia annua and definitive carbon-13 assignments of $\beta$-arteether. Phytochemistry 1993, 33, 1461-1464.

200. van Nieuwerburgh, F.C.W.; van de Casteele, S.R.F.; Maes, L.; Goossens, A.; Inze, D.; van Bocxlaer, J.D.; Dieter, L.D. Quantitation of artemisinin and its biosynthetic precursors in Artemisia annua L. by high performance liquid chromatography-electrospray quadrupole timeof-flight tandem mass spectrometry. J. Chromatogr. A. 2006, 1118, 180-187.

201. Uskobvich, N.R.; Williams, T.H.; Blount, J.F. The structure and absolute configuration of arteannuin B. Helv. Chim. Acta 1974, 57, 600-602.

202. Wang, J.-W.; Zheng, L.-P.; Tan, R.-X. The preparation of an elicitor from a fungal endophyte to enhance artemisinin production in hairy root cultures of Artemisia annua L. Chinese J. Biotechnol. 2006, 22, 829-834.

203. Akhila, A.; Thakur, R.S.; Popli, S.P. Biosynthesis of artemisinin in Artemisia annua. Phytochemistry 1987, 26, 1927-1930.

204. Haynes, R.K.; Vonwiller, S.C. From Qinghao, marvelous herb of antiquity, to the antimalarial trioxane qinghaosu - and some remarkable new chemistry. Acc. Chem. Res. 1997, 30, 73-79.

205. Kasymov, S.Z.; Ovezdurdyev, A.; Yusupov, M. I.; Sham'yanov, I. D.; Malikov, V. M., Lactones of Artemisia annua. Khim. Prir. Soedin. 1986, 5, 636.

206. Kalita, B.; Nabin, C. Synthesis of a new series of $10 \alpha$-nitrodeoxoartemisinin and their antimalarial activity. Indian J. Chem., Sect. B Organic Chemistry including Medicinal Chemistry 2001, 40B, 1125-1128.

207. Deng, A.; Zhu, D.; Jao, Y.; Dai, J.; Xu, R. Studies on the structure of the artemisic acid. Kexue Tongbao 1981, 26, 1209-1211.

208. Kim, S.-U.; Lim, H.-J. Isolation of arteannuic acid from Artemisia annua. Han'guk Nonghwa Hakhoechi 1989, 32, 178-179.

209. Akhila, A.; Rani, K.; Thakur, R.S. Biosynthesis of artemisinic acid in Artemisia annua. Phytochemistry 1990, 29, 2129-2132.

210. Vonwiller, S.C.; Haynes, R.K.; King, G.; Wang, H.-J. An improved method for the isolation of Qinghao (artemisinic) acid from Artemisia annua. Planta Med. 1993, 59, 562-563.

211. van den Berghe, D.R.; Vergauwe, A.N.; van Montagu, M.; van den Eeckhout, E.G. Simultaneous determination of artemisinin and its bioprecursors in Artemisia annua. J. Nat. Prod. 1995, 58, 798-803. 
212. Zhu, D. Studies on the antibacterial artemisinin. Zhongcaoyao (Chinese Traditional and Herbal Drugs) 1982, 13, 6.

213. El-Feraly, F.S.; Ayalp, A.; Al-Yahya, M.A.; McPhail, D.R.; McPhail, A.T. Conversion of artemisinin to artemisitene. J. Nat. Prod. 1990, 53, 66-71.

214. Ranasinghe, A.; Sweatlock, J.D.; Cooks, R.G. A rapid screening method for artemisinin and its congeners using Ms/Ms: Search for new analogues in Artemisia annua. J. Nat. Prod. 1993, 56, 552-563.

215. Sangwan, R.S.; Agarwal, K.; Luthra, R.; Thakur, R.S.; Singh Sangwan, N. Biotransformation of arteannuic acid into arteannuin-B and artemisinin in Artemisia annua. Phytochemistry 1993, 34, 1301-1302.

216. Huang, J.; Xia, Z.; Wu, L. Constituents of Artemisia annua L. I. Isolation and identification of 11R-(-)-dihydroarteannuic acid. Huaxue Xuebao 1987, 45, 609-612.

217. Brown, G.D. Cadinanes from Artemisia annua that may be intermediates in the biosynthesis of artemisinin. Phytochemistry 1994, 36, 637-641.

218. Sy, L.-K.; Brown, G.D. The role of the 12-carboxylic acid group in the spontaneous autoxidation of dihydroartemisinc acid. Tetrahedron 2002, 58, 909-923.

219. Anonymous. Co-ordinating group of research on the structure of Qing Hao Su. A new type of lactone - Qing Hau Sau. K'O Hsueh Tung Pao 1977, 22, 142. (CA 1977, 87, 98788)

220. Blasko, G.; Cordell, G.A.; Lankin, D.C. Definitive ${ }^{1} \mathrm{H}$ and ${ }^{13} \mathrm{C}$ NMR assignments of artemisinin (qinghaosu). J. Nat. Prod. 1988, 51, 1273-1276.

221. Huang, J.; Nicholis, K.M.; Cheng, C.; Wang, Y. Two-dimensional NMR studies of arteannuin. Hиахие Хиеbao 1988, 45, 305-308.

222. Leban, I.; Golic, L.; Japelj, M. Crystal and molecular structure of Qinghaosu: A redetermination. Acta Pharmaceutica Jugoslavica 1988, 38, 71-78.

223. Madhusudanan, K.P.; Vishwakarma, R.A.; Balachandran, S.; Popli, S.P. Mass spectral studies on artemisinin, dihydroartemisinin and artether. Indian J. Chem. Sect. B, Organic Chemistry including Medicinal Chemistry 1989, 28, 751-754.

224. Mi, J. Circular dichroism of some synthetic intermeidates of qinghaosu. Yaowu Fenxi Zazhi 1987, 7, 262-266.

225. Wang, Z.; Nakashima, T.T.; Kopesky, K.R.; Molina, J. Qinghaosu: proton and carbon-13 nuclear magnetic resonance spectral assignments and luminescence. Can. J. Chem. 1985, 63, 3070-3074.

226. Wang, B.-D.; Yin, M.-L.; Shong, G.-Q.; Chen, Z.-L. The ${ }^{13} \mathrm{C}$ NMR spectroscopy of arteannuin analogues. Ниахие Хиеbаo 1986, 44, 834-838.

227. Lisgarten, J.N.; Potter, B.S.; Bantuzeko, C.; Palmer, R.A. Structure, absolute configuration and conformation of the antimalarial compound, artemisinin. J. Chem. Crystallogr. 1998, 28, 539-543.

228. Schmid, G.; Hofheinz, W. Total synthesis of qinghaosu. J. Am. Chem. Soc. 1983, 105, 624-625.

229. Xu, X.-X.; Zhu, J.; Huang, D.-Z.; Zhou, W.-S. Total synthesis of arteannuin and deoxyarteannuin. Tetrahedron 1986, 42, 819-828.

230. Ravindranathan, T.; Kumar, M.A.; Menon, R.B.; Hiremath, S.V. Stereoselective synthesis of artemisinin. Tetrahedron Lett. 1990, 31, 755-758. 
231. Avery, M.A.; Chong, W.K.M.; Jennings White, C. Stereoselective total synthesis of (dextro)artemisinin, the antimalarial constituent of Artemisia annua L. J. Am. Chem. Soc. 1992, 114, 974-979.

232. Bhonsle, J.B.; Pandey, B.; Deshpande, V.H.; Ravindranathan, T. New synthetic strategies towards (dextro)-artemisinin. Tetrahedron Lett. 1994, 35, 5489-5492.

233. Liu, H.-J.; Yeh, W.-L.; Chew, S.-Y. A total synthesis of the antimalarial natural product (+)qinghaosu. Tetrahedron Lett. 1993, 34, 4435-4438.

234. Zhou, W.-S.; Xu, X.-X. Total synthesis of the antimalarial sesquiterpene peroxide quinghaosu and yingzhaosu A. Acc. Chem. Res. 1994, 27, 211-216.

235. Avery, M.A.; Jennings-White, C.; Chong, W.K.M. The total synthesis of (+)-artemisinin and (+)9-desmethylartemisinin. Tetrahedron Lett. 1987, 28, 4629-4632.

236. Ye, B.; Wu, Y.-L. An efficient synthesis of qinghaosu and deoxoqinghaosu from arteannuin acid. J. Chem. Soc., Chem. Commun. 1990, 726-727.

237. Roth, R.J.; Acton, N. A facile semisynthesis of the antimalarial drug qinghaosu. J. Chem. Educ. 1991, 68, 612-613.

238. Acton, N.; Roth, R.J. On the conversion of dihydroartemisininic acid into artemisinin. J. Org. Chem. 1992, 57, 3610-3614.

239. Nowak, D.M.; Lansbury, P.T. Synthesis of (+)-artemisinin and (+)-deoxyartemisinin from arteannuin B and arteannuic aid. Tetrahedron 1998, 54, 319-336.

240. Woerdenbag, H.J.; Pras, N.; Chan, N.G.; Bang, B.T.; Bos, R.; van Uden, W.; van Boi, N.; Batterman, S.; Lugt, C.B. Artemisinin related sesquiterpenes, and essential oil in Artemisia annua during a vegetation period in Vietnam. Planta Med. 1994, 60, 272-275.

241. Ekthawatchai, S.; Lertvorachon, J.; Meepowpan, P.; Thongpanchang, T.; Thebtaranonth, Y.; Yuthavong, Y. An environmentally friendly, low cost, one-pot synthesis of artemisitene. Synth. Commun. 2003, 33, 1855-1860.

242. Zhang, L.; Zhou, W. Structure and synthesis of arteannuin and related compounds. XXIV. Conversion of arteannuin into artemisitene. Youji Ниахие 1988, 8, 329-330.

243. Haynes, R.K.; Vonwiller, S.C. Catalyzed oxygenation of allylic hydroperoxides derived from qinghao (artemisinic) acid. Conversion of qinghao acid into dehydroqinghaosu (artemisitene) and qinghaosu (artemisinin). J. Chem. Soc., Chem. Commun. 1990, 451-453.

244. Duke, M.V.; Paul, R.N.; Elsohly, H.N.; Sturtz, G.; Duke, S.O. Localization of artemisinin and artemisitene in foliar tissues of glanded and glandless biotypes of Artemisia annua L. Int. J. Plant Sci. 1994, 155, 365-372.

245. Zaman, S.S.; Sharma, R.P. Some aspects of the chemistry and biological activity of artemisinin and related antimalarials. Heterocycles 1991, 32, 1593-1638.

246. Butler, A.R. Artemisinin (Qinghaosu): a new type of antimalarial drug. Chem. Soc. Rev. 1992, 21, 85-90.

247. Lansbury, P.T.; Nowak, D.M. An efficient partial synthesis of (dextro)-artemisinin and (dextro)deoxoartemisinin. Tetrahedron Lett. 1992, 33, 1029-1032.

248. Nair, M.S.R.; Basile, D.V. Bioconversion of arteannuin B to artemisinin. J. Nat. Prod. 1993, 56, 1559-1566. 
249. Bharel, S.; Gulati, A.; Abdin, M.Z.; Srivastava, P.S.; Vishwakarma, R.A.; Jain, S.K. Enzymic synthesis of artemisinin from natural and synthetic precursors. J. Nat. Prod. 1998, 61, 633-636.

250. Acton, N.; Klayman, D.L. Artemisitene, a new sesquiterpene lactone endoperoxide from Artemisia annua. Planta Med. 1985, 441-442.

251. El-Feraly, F.S.; Al-Meshal, I.A.; Al-Yahya, M.A.; Hifnawy, M.S. On the possible role of qinghao acid in the biosynthesis of artemisinin. Phytochemistry 1986, 25, 2777-2778.

252. Gu, H. Pharmacological studies on artemisinin and its derivatives as antimalarial. Int. Congr. Ser. - Excerpta Med. 1987, 750, 657-660.

253. Wei, Z.; Pan, J.; Li, Y. Artemisinin G: a sesquiterpene from Artemisia annua. Planta Med. 1992, 58, 300 .

254. Jung, M.; ElSohly, H.N.; Croom, E.M.; McPhail, A.T.; McPhail, D.R. Practical conversion of artemisinic acid into desoxyartemisinin. J. Org. Chem. 1986, 51, 5417-5419.

255. Jung, M.; Li, X.; Bustos, D.A.; El-Sohly, H.N.; McChesney, J.D. A short and stereosepcific synthesis of (+)-deoxoartemisinin and (-)-deoxodesoxyartemisinin. Tetrahedron Lett. 1989, 30, 5973-5976.

256. Yang, R.-Y.; Zeng, X.-M.; Lu, Y.-Y.; Lu, W.-J.; Feng, L.-L.; Yang, X.-Q.; Zeng, Q.-P. Senescent leaves of Artemisia annua are one of the most active organs for overexpression of artemisinin biosynthesis responsible genes upon burst of singlet oxygen. Planta Med. 2010, 76, 734-742.

257. de Oliveira, C.M.; Ferracini, V.L.; Foglio, M.A.; de Meijire, A.; Marsaioli, A.J. Detection, synthesis and absolute configuration of (+)-nortaylorione, a new terpene from Artemisia annua. Tetrahedron Asymm. 1997, 8, 1833-1839.

258. Mercke, P.; Crock, J.; Croteau, R.; Brodelius, P.E. Cloning, expression and characterization of epi-cedrol synthase, a sesquiterpene cyclase from Artemisia annua L. Arch. Biochem. Biophys. 1999, 369, 213-222.

259. Hua, L.; Matsuda, S.P.T. The molecular cloning of 8-epicedrol synthase from Artemisia annua. Arch. Biochem. Biophys. 1999, 369, 208-212.

260. Wong, H.-F.; Brown, G.D. Photo-oxygenation of phytol and the structure revision of phytene1,2-diol from Artemisia annua to phytene-1-ol-2-hydroperoxide. J. Chem. Res. 2002, 30-33.

261. Brown, G.D. Phytene-1,2-diol from Artemisia annua. Phytochemistry 1994, 36, 1553-1554.

262. Shukla, A.; Farooqi, A.H.A.; Shukla, Y.N. Growth inhibitors from Artemisia annua. Indian Drugs 1991, 28, 376-377.

263. Feng, L.; Zeng, Q. Cloning and sequencing of Artemisia annua squalene synthase gene and its cDNA. Guangzhou Zhongyiyao Daxue Xuebao 2004, 21, 387-390.

264. Li, Z.; Wang, H.; Wang, H.; Li, G.; Ye, H. Escherichia coli expression, purification and functional identification of a squalene synthase from Artemisia annua L. Yingyong Yu Huanjung Shengwu Xuebao 2007, 13, 309-312.

265. Liu, Y.; Ye, H.; Wang, H.; Li, G. Molecuar cloning, Escherichia coli expression and genomic organization of squalene synthase gene from Artemisia annua. Acta Bot. Sin. 2003, 45, 608-613.

267. Feng, L.-L.; Yang, R.-Y; Yang, X.-Q.; Zeng, Q.-P. Gene targetting of squalene synthase in Artemisia annua. Zhongcaoyao 2006, 37, 1857-1861. 
268. Zhang, Y.; Liu, Y.; Wang, H.; Ye, H.; Li, G. Regulation of squalene synthase gene expression in tobacco by antisense transformation with Artemisia annua squalene synthase gene. Nongye Shengwu Jishu Xuebao 2005, 13, 416-422.

269. Kirby, J.; Romanini, D.W.; Paradise, E.M.; Keasling, J.D. Engineering triterpene production in Saccharomyces cerevisiae - $\beta$ amyrin synthase from Artemisia annua. FEBS J. 2008, 275, 1852-1859.

270. Shukla, A.; Farooqi, A.H.A.; Shukla, Y.N. A new adenine derivative from Artemisia annua. J. Indian Chem. Soc. 1997, 74, 59.

271. Lu, S.; Chen, X.-Y. Terpenoid metabolism in cotton (Gossypium spp.) and qinghao. Adv. Plant Physiol. 2005, 8, 265-292.

272. Haynes, R.K. From artemisinin to new antimalarials: biosynthesis, extraction, old and new derivatives and medicinal chemistry requirements. Curr. Top. Med. Chem. 2006, 6, 509-537.

273. Ryden, A.-M.; Kayser, O. Chemistry, biosynthesis and biological activity of artemisinin and related natural peroxides. Top. Heterocycl. Chem. 2007, 9, 1-31.

274. Bharel, S.; Gulati, A.; Abdin, M.Z.; Srivastava, P.S.; Jain, S.K. Structure, biosynthesis and functions of artemisinin. Fitoterapia 1996, 67, 387-402.

275. Liu, C.; Wang, Y.; Quyang, F. Advance in artemisinin biosynthesis research. Tianran Chanwu Yanjiu Yu Kaifa 2000, 12, 83-86.

276. Chen, D.-H.; Ye, H.-C.; Li, G.-F.; Liu, Y. Advances in molecular biology of plant isoprenoid metabolic pathway. Zhiwu Xuebao 2000, 42, 551-558.

277. Wang, H.-Y.; Ye, H.; Liu, B.; Li, Z.; Li, G. Advances in molecular regulation of artemisinin biosynthesis. Shengwu Gongcheng Xuebao 2003, 19, 646-650.

278. Weathers, P.J.; Elkholy, S; Wobbe, K.K. Artemisinin: the biosynthetic pathway and its regulation in Artemisia annua, a terpenoid-rich species. In Vitro Cell. Dev. Biol.: Plant 2006, 42, 309-317.

279. Covello, P.; Teoh, K.; Polichuk, D.R.; Reed, D.W.; Nowak, G. How the antimalarial artemisinin is made in plants. Abstracts of Papers; In Prceedings of 234th ACS national Meeting, Boston, MA, USA, August 19-23, 2007.

280. Covello, P.; Teoh, K.H.; Polichuk, D.R.; Reed, D.W.; Nowak, G. Functional genomics and the biosynthesis of artemisinin. Phytochemistry 2007, 68, 1864-1871.

281. Wang, Y.; Xia, Z.; Zhou, F.; Wu, Y.; Huang, J.; Wang, Z. Studies on the biosynthesis of arteannuin. III. Arteannuic acid as a key intermediate in the biosyntheses of arteannuin and arteannuin B. Huaxue Xuebao 1988, 46, 1152-1153.

282. Chen, P.-K.; Lukonis, C.; Go, L.; Leather, G.R. Increasing artemisinin production through biotransformation of precursors. Proc. Plant Growth Regul. Soc. Am. 1991, 2-8.

283. Li, Y.; Yang, Z.-X.; Chen, Y.-X.; Zhang, X. Synthesis of $\left[15-{ }^{14} \mathrm{C}\right]$ labeled artemisinin. Yaoxue Xuebao (Acta Pharmaceutica Sinica) 1994, 29, 713-716.

284. Wang, Y.; Xia, Z.; Zhou, F.; Wu, Y.; Huang, J.; Wang, Z. Studies on the biosynthesis of arteannuin. IV. The biosynthesis of arteannuin and arteannuin B by the leaf homogenate of Artemisia annua L. Chin. J. Chem. 1993, 11, 457-463.

285. Nair, M.S.; Basile, D.V. Use of cell-free systems in the production of the potent antimalarial, artemisinin. Indian J. Chem., Sect. B 1992, 31B, 880-882. 
286. Wang, Y.; Shen, Z.; Xia, Z.; Zhou, F. Studies on the biosynthesis of arteannuin. V. The role of 6epi-deoxyarteannuin B in arteannuin biosynthesis. Chin. J. Chem. 1993, 11, 476-478.

287. Towler, M.J.; Weathers, P.J. Evidence of artemisinin production from IPP stemming from both mevalonate and non-mevalonate pathways. Plant Cell Rep. 2007, 26, 2129-2136.

288. Kudaksseril, G.J.; Lam, L.; Staba, E.J. Effect of sterol inhibitors on the incorporation of carbon14 isopentenyl pyrophosphate into artemisinin by a cell-free system from Artemisia annua tissue cultures and plants. Planta Med. 1987, 53, 280-284.

289. Marchese, J.A.; Broetto, F.; Ming, L.C.; Ducatti, C.; Rodella, R.A.; Ventrella, M.C.; Gomes, G.D.R.; de Franchesci, L. Carbon isotope composition and leaf anatomy as a tool to characterize the photosynthetic mechanism of Artemisia annua L. Braz. J. Plant Physiol. 2005, 17, 187-190.

290. Matsushita, Y.; Kang, W.; Charlwood, B.V. Cloning and anaysis of a cDNA encoding farnesyl diphosphate synthase from Artemisia annua. Gene 1996, 172, 207-209.

291. Bouwmeester, H.J.; Wallaart, T.E.; Janssen, M.H.A.; van Loo, B.; Jansen, B.J.M.; Posthumus, M.A.; Schmidt, C.O.; de Kraker, J.W.; Koenig, W.A.; Franssen, M.C.R. Amorpha-4,11-diene synthase catalyses the first probable step in artemisinin biosynthesis. Phytochemistry 1999, 52, 843-854.

292. Shen, H.-Y.; Li, Z.-Q.; Wang, H.; Ma, L.-Q.; Liu, B.-Y; Yan, F.; Li, G.-F.; Ye, H.-C. Advances in sesquiterpene synthase cyclases of Artemisia annua. Shengwu Gongcheng Xuebao 2007, 23, 976-981.

293. Jang, Y.-J.; Kim, S.-U.; Park, S.-H.; Song, S.-H. Amorpha-4,11-diene synthase of Artemisia annua, its coding gene, expression vector containing the gene and E. coli and plant transformants transformed with the vector. Repub. Korean Kongkae Taeho Kongbo 2001.

294. Wallaart, T.E.; Bouwmeester, H.J.; Hille, J.; Poppinga, L.; Maijers, N.C.A. Amorpha-4,11-diene synthase: cloning and functional expression of a key enzyme in the biosynthetic pathway of the novel antimalarial drug artemisinin. Planta 2001, 212, 460-465.

295. Kim, S.-H.; Heo, K.; Chang, Y.-J.; Park, S.-H.; Rhee, S.-K.; Kim, S.-U. Cyclization mechanism of amorpha-4,11-diene synthase, a key enzyme in artemisinin biosynthesis. J. Nat. Prod. 2006, 69, 758-762.

296. Mercke, P.; Bengtsson, M.; Bouwmeester, H.J.; Posthumus, M.A.; Brodelius, P.E. Molecular cloning, expression, and characterization of amorpha-4,11-diene synthase, a key enzyme of artemisinin biosynthesis in Artemisia annua L. Arch. Biochem. Biophys. 2000, 381, 173-180.

297. Kim, N.-C.; Kim, J.-G.; Lim, H.-J.; Hahn, T.R.; Kim, S.-U. Production of secondary metabolites by tissue culture of Artemisia annua L. J. Kor. Agric. Chem. Soc. 1992, 35, 99-105.

298. Zhang, Y.; Teoh, K.H.; Reed, D.W.; Maes, L.; Goossens, A.; Olson, D.J.H.; Ross, A.R.S.; Covello, P.S. The Molecular cloning of artemisinic aldehyde $\Delta 11(13)$ reductase and its role in glandular trichome-dependent biosynthesis of artemisinin in Artemisia annua. J. Biol. Chem. 2008, 283, 21501-21508.

299. Zhang, Y.; Liu, B.; Li, Z.; Ye, H.; Wang, H.; Li, G.; Han, J. Molecular cloning of a classical plant peroxidase from Artemisia annua and its effect on the biosynthesis of artemisinin in vitro. Acta Bot. Sin. 2004, 46, 1338-1346.

300. Zhang, Y.; Ye, H.; Li, G. Effect of horseradish peroxidase on the biosynthesis of artemisinin in Artemisia annua in vitro. Yingyong Yu Huanjung Shengwu Xuebao 2003, 9, 616-618. 
301. Lommen, W.J.M.; Bouwmeester, H.J.; Verstappen, F.W.A. Trichome dynamics and artemisinin accumulation during development and senescence of Artemisia annua leaves. Planta Med. 2006, 72, 336-345.

302. Vonwiller, S.C.; Warner, J.A.; Mann, S.T.; Haynes, R.K. Copper (II) trifluoromethanesulfonateinduced cleavage oxygenation of allylic hydroperoxides derived from qinghao acid in the synthesis of qinhaosu derivatives: evidence for the intermediacy of enols. J. Am. Chem. Soc. 1995, 117, 11098-11105.

303. Vonwiller, S.C.; Warner, J.A.; Mann, S.T.; Haynes, R.K. The formation of a peracetal and trioxane from an enol ether with Copper(II) triflate and oxygen: unexpected oxygenation of aldol intermediates. Tetrahedron Lett. 1997, 38, 2363-2366.

304. Adam, W.; Kliem, U.; Lucchini, V. Preparative UV-VIS laser photochemistry: Photocycloadditions of methylenelactones with benzophenone and p-benzoquinone: Oxygen trapping of Paterno-Buchi triplet 1,4-diradicals as model reactions for Qinghaosu-type 1,2,4trioxanes. Liebigs Ann. Chem. 1988, 869-875.

305. Adam, W.; Kliem, U.; Mosandl, T.; Peters, E.M.; Peters, K.; von Schnering, H.G. Preparative visible-laser photochemistry: Qinghaosu-type 1,2,4-trioxanes by molecular oxygen trapping of Paterno-Buchi triplet 1,4-diradicals derived from 3,4-dihydro-4,4-dimethyl-2H-pyran-2-one and quinones. J. Org. Chem. 1988, 53, 4986-4992.

306. Cumming, J.N.; Wang, D.; Park, S.B.; Shapiro, T.A.; Posner, G.H. Design, synthesis, derivatization, and structure-activity relationships of simplified, tricyclic, 1,2,4-trioxane alcohol analogues of the antimalarial artemisinin. J. Med. Chem. 1998, 41, 952-964.

307. Kim, N.-C.; Kim, S.-U. Biosynthesis of artemisinin from 11, 12-dihydroarteannuic acid. J. Kor. Agric. Chem. Soc. (Han'guk Nonghwa Hakhoechi) 1992, 35, 106-109.

308. Huang, J.; Zhou, F.; Wu, L.; Zeng, G. Biosynthesis of arteannuin. I. In vivo biosynthesis of arteannuic acid of Artemisia annua. Нuaxue Xuebao 1990, 48, 275-7.

309. Tatineni, R.; Doddapaneni, K.K.; Dalavayi, S.; Kulkarni, S.M.; Narasu, M.L. Microbacterium trichothecenolyticum enzyme mediated transformation of arteannuin B to artemisinin. Process Biochem. 2006, 41, 2464-2467.

310. Dhingra, V.; Narasu, M.L. Purification and Characterization of an enzyme involved in biochemical transformation of arteannuin B to artemisinin from Artemisia annua. Biochem. Biophys. Res. Commun. 2001, 281, 558-561.

311. Dhingra, V.; Rajoli, C.; Narasu, M.L. Partial purification of proteins involved in the bioconversion of arteannuin B to artemisinin. Bioresource Technol. 2000, 73, 279-282

312. Abdin, M.Z.; Israr, M.; Kumar, P.A.; Jain, S.K. Molecular approaches to enhance artemisinin content in Artemisia annua L. Recent Prog. Med. Plants 2004, 4, 145-161.

313. Brown, G.D. Production of anti-malarial and anti-migraine drugs in tissue culture of Artemisia annua and Tanacetum parthenium. Acta Hortic. 1993, 330, 269-276.

314. Covello, P. Making artemisinin. Phytochemistry 2008, 69, 2881-2885.

315. Abdin, M.Z.; Jain, S.K. Artemisinin, a novel antimalarial drug: biochemical and molecular approaches for enhanced production. Planta Med. 2003, 69, 289-299.

316. Dhingra, V.; Rao, K.V.; Narasu, M.L. Current status of artemisinin and its derivatives as antimalarial drugs. Life Sci. 1999, 66, 279-300. 
317. Liu, C.; Wang, Y.; Ouyang, F.; Ye, H.; Li, G. Advances in artemisinin research. Huaxue Jinzhan 1999, 11, 41-48.

318. van Geldre, E.; Vergauwe, A.; van den Eeckhout, E. State of the art of the production of the antimalarial compound artemisinin in plants. Plant Mol. Biol. 1997, 33, 199-209.

319. Gulati, A.; Bharel, S.; Srivastava, P.S.; Abdin, M.Z.; Jain, S.K. Experimental studies on Artemisia, a herbal remedy to malaria. Fitoterapia 1996, 67, 403-410.

320. Wu, J.; Ding, W.; Zhang, Y.; Zhou, Y. Advances in studies on biotechnology of getting highyield artemisinin. Zhongcaoyao 2007, 38, 305-308.

321. Laughlin, J.C. Agricultural production of artemisinin - a review. Trans. R. Soc. Trop. Med. Hyg. 1994, 88, 21-22.

322. de Magalhaes, P.M.; Pereira, B.; Sartoratto, A.; de Oliveira, J.; Debrunner, N. New hybrid lines of the antimalarial species Artemisia annua L. Acta Hortic. 1999, 502, 377-381.

323. Delabays, N.; Benakis, A.; Collet, G., Selection and breeding for high artemisinin (qinghaosu) yielding strains of A. annua L. Acta Hortic. 1993, 330, 203-205.

324. Simmonet, X.; Carlen, C. New Artemisia annua hybrids with high artemisinin content. Acta Hortic. 2008, 769, 371-373.

325. Ferreira, J.F.S.; Janick, J. Floral morphology of Artemisia annua with special reference to trichomes. Int. J. Plant Sci. 1995, 156, 807-815.

326. Liersch, R.; Soicke, H.; Stehr, C.; Tuellner, H.U. Formation of artemisinin in Artemisia annua during one vegetation period. Planta Med. 1986, 387-390.

327. Singh, A.; Vishwakarma, R.A.; Husain, A. Evaluation of Artemisia annua strains for higher artemisinin production. Planta Med. 1988, 54, 475-476.

328. Wang, H.; Li, G.-F. Studies on the effects of fpf1 gene on Artemisia annua flowering time and on the linkage between flowering and artemisinin biosynthesis. Planta Med. 2004, 70, 347-352.

329. Ferreira, J.F.S.; Simon, J.E.; Janick, J. Developmental studies of Artemisia annua: Flowering and artemisinin production under greenhouse and field conditions. Planta Med. 1995, 61, 167-170.

330. Jain, D.C.; Mathur, A.K.; Gupta, M.M.; Singh, A.K.; Verma, R.K.; Gupta, A.P.; Kumar, S. Isolation of high artemisinin-yielding clones of Artemisia annua. Phytochemistry 1996, 43, 993-1001.

331. Chen, H.; Chen, M.; Zhong, F.; Chen, F.; Huang, J.; Zhang, M.; Huang, J. Factors affecting the content of artemisinin in Artemisia annua. Zhongyao Tongbao 1986, 11, 393-395.

332. Chen, F.; Zhang, G. Studies of several physiological factors on artemisinin synthesis in Artemisia annua. Zhiwu Shenglixue Tongxun 1987, 5, 26-30.

333. Wang, J.-X.; Wang, Z.-M. Effects of irradiance on growth, photosynthetic characteristics and artemisinin content of Artemisia annua L. Photosynthetica 2008, 46, 17-20.

334. Gupta, S.S.; Singh, P.; Bajpai, P.; Ram, G.; Singh, D.; Gupta, M.M.; Jain, D.C.; Khanuja, S.P.; Kumar, S. Morphogenetic variation for artemisinin and volatile oil in Artemisia annua. Ind. Crops Prod. 2002, 16, 217-224.

335. Ferreira, J.F.S. Nutrient deficiency in the production of artemisinin, dihydroartemisinic acid, and artemisinic acid in Artemisia annua L. J. Agric. Food Chem. 2007, 55, 1686-1694.

336. Kawamoto, H.; Sekine, H.; Furuya, T. Production of artemisinin and related sesquiterpenes in Japanese Artemisia annua during a vegetation period. Planta Med. 1999, 65, 88-89. 
337. Laughlin, J.C. The influence of distribution of antimalarial constituents in Artemisia annua L. on time and method of harvest. Acta Hortic. 1995, 390, 67-73.

338. Wallaart, T.E.; Pras, N.; Beekmann, A.C.; Quax, W.J. Seasonal variation of artemisinin and its biosynthetic precursors in plants of Artemisia annua of different geographical origin. Proof for the existence of chemotypes. Planta Med. 2000, 66, 57-62.

339. Yang, R.-Y.; Zeng, Q.-P. Quantitative transcript profiling reveals down-regulation of a sterol pathway relevant gene and overexpression of artemisinin biogenetic genes in transgenic Artemisia annua plants. Planta Med. 2008, 74, 1510-1516.

340. Zhang, L.; Jing, F.; Fupeng, L. Development of transgenic Artemisia annua (Chinese wormwood) plants with enhanced content of artemisinin, an effective antimalarial drug, by hairpin-RNA-mediated gene silencing. Biotechnol. Appl. Biochem. 2009, 52, 199-207.

341. Han, J.-L.; Wang, H.; Ye, H.-C.; Liu, Y.; Li, Z.-Q.; Zhang, Y.; Zhang, Y.-S.; Yan, F.; Li, G.-F. High efficiency of genetic transformation and regeneration of Artemisia annua L. via Agrobacterium tumefaciens-mediated procedure. Plant Sci. 2004, 168, 73-80.

342. Martinez, B.C.; Staba, E.J. The production of artemisinin in Artemisia annua L. tissue cultures. Adv. Cell Cult. 1988, 6, 69-87.

343. Ferreira, J.F.S.; Janick, J. Roots as an enhancing factor for the production of artemisinin in shoot cultures of Artemisia annua. Plant Cell Tissue Org. Cult. 1996, 44, 211-217.

344. Chen, P.-K.; Hua, H.; Yim, J.-W. Enhanced synthesis of the natural phytotoxin artemisinin in tissue culture. PGRSA Q. 1993, 21, 151-160.

345. Zhang, L.; Li, G. Related factors of artemisinin biosynthesis in clone strain of Artemisia annua L. Yingyong Yu Huanjung Shengwu Xuebao 2004, 10, 277-280.

346. Nair, M.S.R.; Acton, N.; Klayman, D.L.; Kendrick, K.; Basile, D.V.; Mante, S. Production of artemisinin in tissue cultures of Artemisia annua. J. Nat. Prod. 1986, 49, 504-507.

347. Elhag, H.M.; E1-Domiaty, M.M.; E1-Feraly, F.S.; Mossa, J.S.; E1-Olemy, M.M. Selection and micropropagation of high artemisinin producing clones of Artemisia annua L. Phytother. Res. 1992, 6, 20-24.

348. Li, H.; Yi, Z.; Yong, G.; Yao, R. Artificial regulation of artemisinin biosynthesis metabolite in cultured cells of Artemisia annua. Zhongguo Shengwu Huaxue Yu Fenzi Shengwu Xuebao 1999, $15,479-483$.

349. Xie, D.; Li, G. Isolation and production of artemisinin and stigmasterol in hairy root cultures of Artemisia annua. Plant Cell Tissue Org. Cult. 2001, 63, 161-166.

350. Xie, D.; Li, G.; Guo, Z., Selection of hairy root clones of Artemisia annua L. for artemisinin production. Isr. J. Plant Sci. 2001, 49, 129-134.

351. Chen, D.-H.; Chun, Y.-H.; Li, G.-F. Expression of a chimeric farnesyl diphosphate synthase gene in Artemisia annua L. transgenic plants via Agrobacterium tumefaciens-mediated transformation. Plant Sci. 2000, 155, 179-185.

352. Wang, J.; Tan, R.-X. Preparation of an elicitor from a fungal endophyte to enhance artemisinin production in hairy root culture of Artemisia annua L. Shengwu Gongcheng Xuebao 2006, 22, 829-834.

353. Wang, J.-W.; Xiang, R. Stimulation of artemisinin production in Artemisia annua hairy roots by the elicitor from the endophytic Colleotrichum Ssp. Biotechnol. Lett. 2001, 23, 857-860. 
354. Wobbe, K.K.; Zhang, X.; Weathers, P. Correlations between peroxidase activity, calcium and artemisinin levels in hairy roots of Artemisia annua L. Curr. Top. Plant Physiol. 1998, 432-434.

355. Woerdenbag, H.J.; Pras, N.; van Uden, W.; de Boer, A.; Batterman, S.; Visser, J.F.; Malingre, T.M. High peroxidase activity in cell cultures of Artemisia annua with minute artemisinin contents. Nat. Prod. Lett. 1992, 1, 121-128.

356. Steirle, A.; Strobel, G.A.; Stierle, D. Taxol and taxane production by Taxomyces andreanae, an endophytic fungus of Pacific Yew. Science 1993, 260, 214-216.

357. Liu, C.-H.; Zou, W.-X.; Lu, H.; Tan, R.-X. Antifungal activity of Artemisia annua endophyte cultures against phytopathenogenic fungi. J. Biotechnol. 2001, 88, 277-282.

358. Simanjuntak, P.; Bustanussalam; O.; Dian M.; Rahayuningsih, M.; Said, E.G. Studies on endophytic microbes of Artemisia spp (3). Isolation and identification of artemisinin from product of endophyte microbe cultivation from Artemisia annua. Majalah Farmasi Indonesia 2004, 15, 68-74.

359. Shen, L.; Jiao, R.-H.; Ye, Y.-H.; Wang, X.-T.; Xu, C.; Song, Y.-C.; Zhu, H.-L.; Tan, R.-X. Absolute configuration of new cytotoxic and other bioactive tricothecene macrolides. Chem. Eur. J. 2006, 12, 5596-5602.

360. Gu, W.; Ge, H.M.; Song, Y.C.; Ding, H.; Zhu, H.L.; Zhao, X.A.; Tan, R.-X. Cytotoxic Benzo[j]fluoranthene metabolites from Hypoxylon truncatum IFB-18, an endophyte of Artemisia annua. J. Nat. Prod. 2007, 70, 114-117.

361. Liu, J.-Y.; Liu, C.-H.; Zou, W.-X.; Tan, R.-X. Leptosphaeric acid, a metabolite with a novel carbon skeleton from Leptosphaeria sp. IV403, an endophytic fungus in Artemisia annua. Helv. Chim. Acta 2003, 86, 657-660.

362. Liu, J.-Y.; Liu, C.-H.; Zou, W.-X.; Tian, X.; Tan, R.-X. Leptosphaerone, a metabolite with a novel skeleton from Leptosphaeria sp. IV403, an endophytic fungus in Artemisia annua. Helv. Chim. Acta 2002, 85, 2664-2667.

363. Lu, H.; Zou, W. X.; Meng, J. C.; Hu, J.; Tan, R.X. New bioactive metabolites produced by Colletotrichum sp., an endophytic fungus in Artemisia annua. Plant Sci. 2000, 151, 67-73.

364. Keasling, J. D., Synthetic biology for synthetic chemistry. ACS Chem. Biol. 2008, 3, 64-76.

365. Huang, Y.; Zeng, Q. Genetic manipulation on biosynthesis of terpenoids. Zhongguo Shengwu 2006, 26, 60-64.

366. Zeng, Q.-P.; Yuan, L. Production of artemisinin by genetically modified microbes. Biotechnol. Lett. 2008, 30, 581-592.

367. Withers, S.T.; Keasling, J.D. Biosynthesis and engineering of small isoprenoid molecules. Appl. Microbiol. Biotechnol. 2007, 73, 980-990.

368. Lee, S.-Y.; Kim, H.-U.; Park, J.-H.; Park, J.-M.; Kim, T.-Y. Metabolic engineering of microorganisms. Drug Discov. Today 2009, 14, 78-88.

369. Liu, C.; Zhao, Y.; Wang, Y., Artemisinin: current status and perspectives for biotechnological production of an antimalarial drug. Appl. Microbiol. Biotechnol. 2006, 72, 11-20.

370. Kong, J.-Q.; Cheng, K.; Wang, L.; Zheng, X.; Dai, J.; Zhu, P.; Wang, W. Increase of copy number of HMG-CoA reductase and FPP synthase genes improves the amorpha-4,11-diene production in engineered yeast. Yaохиe Хиebao 2007, 42, 1314-1319. 
371. Kim, O. T.; Ahn, J.C.; Hwang, S.J.; Hwang, B. Cloning and expression of a farnesyl diphosphate synthase in Centella asiatica (L.) Urban. Mol. Cells 2005, 19, 294-299.

372. Chen, D.-H.; Liu, C.-J.; Ye, H.-C.; Li, G.-F.; Liu, B.-Y.; Men, Y.-L.; Chen, X.-Y. Ri-mediated transformation of Artemisia annua with a recombinant farnesyl diphosphate synthase gene for artemisinin production. Plant Cell Tissue Org. Cult. 1999, 57, 157-162.

373. Zhao, Y.; Ye, H.; Li, G.; Chen, D.; Liu, Y. Cloning and enzymology analysis of farnesyl pyrophosphate synthase gene from a superior strain of Artemisia annua L. Chin. Sci. Bull. 2003, $48,63-67$.

374. Han, J.-L.; Li, G. Effects of overexpression of the endogenous farnesyl diphosphate synthase on the artemisinin content in Artemisia annua L. J. Integr. Plant Biol. 2006, 48, 482-487.

375. Huang, Y.; Yin, L.; Feng, L.; Yang, R.; Yang, X.; Zeng, Q.-P. Cloning and expression of Artemisia annua L. amorpha-4,11-diene synthase gene. Guangzhou Zhongyiyao Daxue Xuebao 2008, 25, 68-73.

376. Kong, J.-Q.; Wang, W.; Wang, L.-N.; Zhong, X.-D.; Cheng, K.-D.; Zhu, P. The improvement of amorpha-4,11-diene production by a yeast-conform variant. J. Appl. Microbiol. 2009, 106, 941-951.

377. Chang, Y.-J.; Song, S.-H.; Park, S.-H.; Kim, S.-U. Amorpha-4,11-diene synthase of Artemisia annua: cDNA isolation and bacterial expression of a terpene synthase involved in artemisinin biosynthesis. Arch. Biochem. Biophys. 2000, 383, 178-184.

378. Chang, M.C.Y.; Eachus, R.A.; Trieu, W.; Ro, D.-K.; Keasling, J.D. Engineering Escherichia coli production of functionalized terpenoids using plant P450s. Nat. Chem. Biol. 2007, 3, 274-277.

379. Huang, B.; Guo, J.; Yi, B.; Yu, X.; Sun, L.; Chen, W. Heterologous production of secondary metabolites as pharmaceuticals in Saccharomyces cerevisiae. Biotechnol. Lett. 2008, 30, 1121-1137.

380. Lindahl, A.-L.; Olsson, M.E.; Mercke, P.; Tollbom, O.; Schelin, J.; Brodelius, M.; Brodelius, P.E. Production of the artemisinin precursor amorpha-4,11-diene by engineered Saccharomyces cerevisiae. Biotechnol. Lett. 2006, 28, 571-580.

381. Newman, J.D.; Marshall, J.; Chang, M.; Nowroozi, F.; Paradise, E.; Pitera, D.; Newman, K.L.; Keasling, J.D. High-level production of amorpha-4,11-diene in a two phase partitioning bioreactor of metabolically engineered Escherichia coli. Biotechnol. Bioeng. 2006, 95, 684-691.

382. Anthony, J.R.; Anthony, L.C.; Nowroozi, F.; Kwon, G.; Newman, J.D.; Keasling, J.D. Optimization of the mevalonate-based isoprenoid biosynthetic pathway in Escherichia coli for production of the antimalarial drug precursor amorpha-4,11-diene. Metab. Eng. 2009, 11, 13-19.

383. Picaud, S.; Olsson, M.E.; Brodelius, P.E. Improved conditions for production of recombinant plant sesquiterpene synthases in Escherichia coli. Prot. Expr. Purif. 2007, 51, 71-79.

384. Keasling, J.D. Engineering microbes for anti-malarial production. Abstracts of Papers; In Proceedings of 229th ACS National Meeting, San Diego, CA, USA, March 13-17, 2005.

385. Ro, D.-K.; Paradise, E.M.; Ouellet, M.; Fisher, K.J.; Newman, K.L.; Ndungu, J.M.; Ho, K.A.; Eachus, R.A.; Ham, T.S.; Kirby, J.; Chang, M.C.Y.; Withers, S.T.; Shiba, Y.; Sarpong, R.; Keasling, J.D. Production of the antimalarial drug precursor artemisinic acid in engineered yeast. Nature 2006, 440, 940-943. 
386. Ro, D.-K.; Ouellet, M.; Paradise, E.M.; Burd, H.; Eng, D.; Paddon, C.J.; Newman, J.D.; Keasling, J.D. Induction of multiple pleiotropic drug resistance genes in yeast engineered to produce an increased level of anti-malarial drug precursor, artemisinic acid. BMC Biotechnol. 2008, 8 .

387. Dietrich, J.A.; Yoshikuni, Y.; Fisher, K.J.; Woolard, F.X.; Ockey, D.; McPhee, D.J.; Renninger, N.S.; Chang, M.C.Y.; Baker, D.; Keasling, J.D. A novel semi-biosynthetic route for artemisinin production using engineered substrate-promiscuous P450BM3. ACS Chem. Biol. 2009, 4, 261-267.

388. Sy, L.-K.; Brown, G.D. Novel seco-cycloartanes from Kadsura coccinea and the assisted autoxidation of a tri-substituted alkene. Tetrahedron 1999, 55, 119-132.

Sample Availability: Not available.

(C) 2010 by the authors; licensee MDPI, Basel, Switzerland. This article is an Open Access article distributed under the terms and conditions of the Creative Commons Attribution license (http://creativecommons.org/licenses/by/3.0/). 